Report No. 1777a-Af

Gineral Dos 3 ACKU 000355791

Afghanistan

The Journey to Economic Development

(In Two Volumes)

Volume I: The Main Report

March 17, 1978

Country Programs Department I

Europe, Middle East and North Africa Region
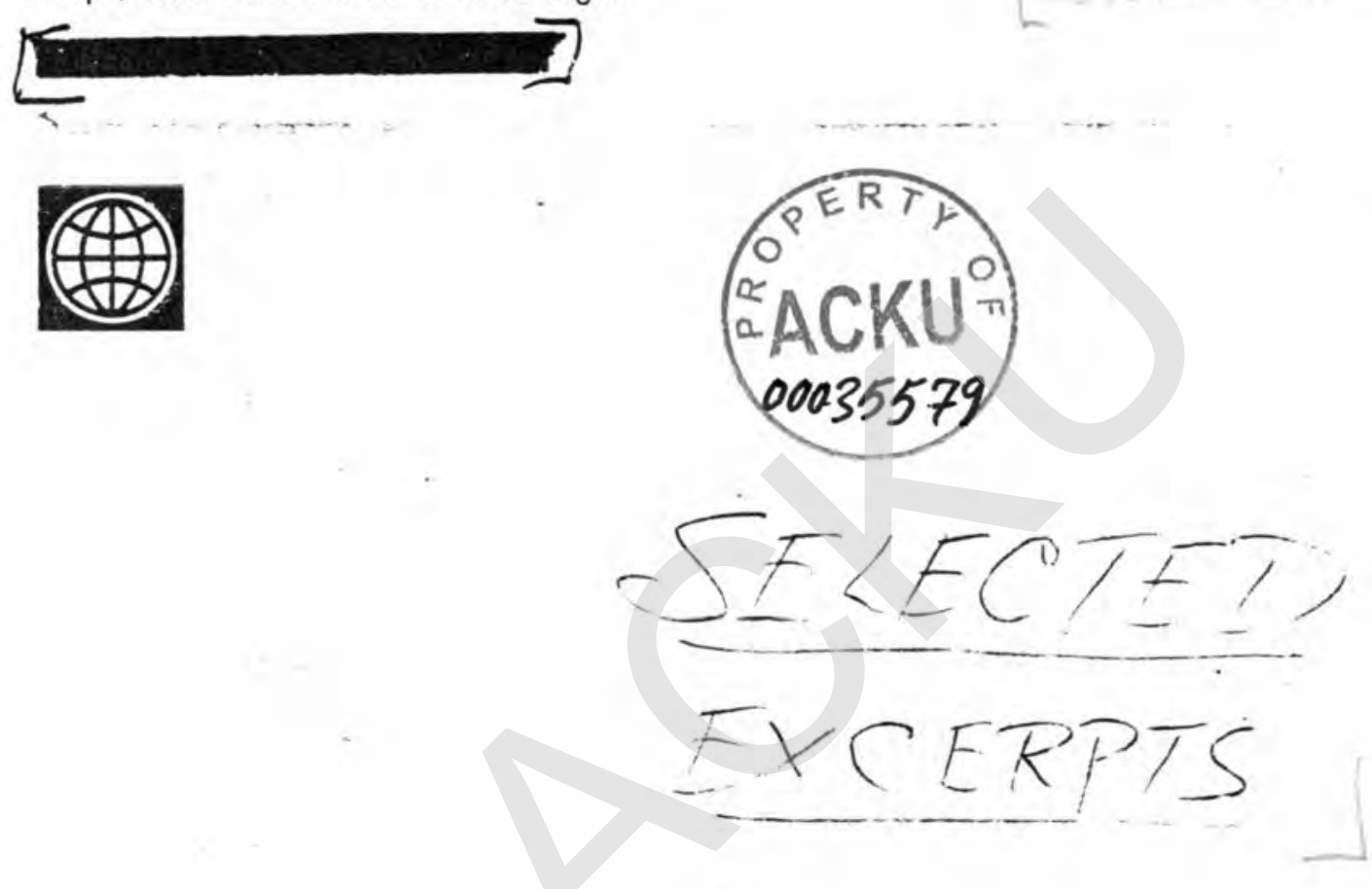

Document of the World Bank

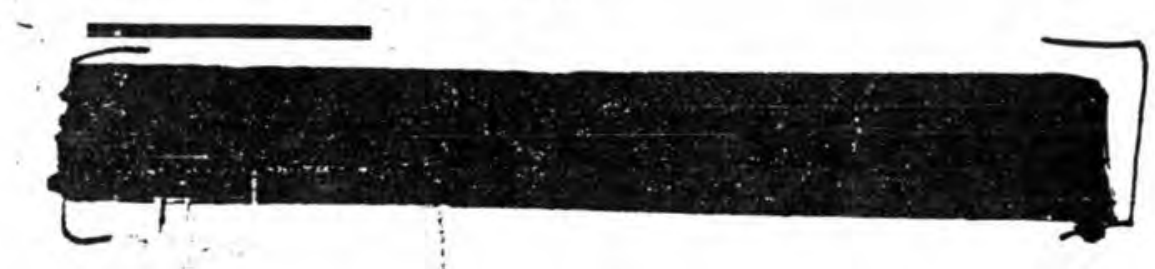


Calculations in this report have been based on the average free rate for $1976 / 77$ as follows:

$$
\begin{aligned}
& \text { US\$1.00 }=\text { Af } 47.38 \\
& \text { Af } 1.00=\text { US\$0.0211 }
\end{aligned}
$$

By December 31, 1977 the rate had appreciated to Af $\mathbf{4 3}$ to the dollar

\section{WEIGHTS AND MEASURES}

1 Jerib $=0.2$ hectare

1 Seer $=7,14 \mathrm{kilogram}$

\begin{tabular}{|c|c|}
\hline AFC & - Afghan Fertilizer Company \\
\hline ASC & - Afghan Seed Company \\
\hline AgBank & - Agricultural Development Bank \\
\hline$D A B$ & - Da Afghanistan Bank \\
\hline DAF & - Development Assistance Fund \\
\hline FAO & - Food and Agricultural Organization \\
\hline EPD & - Food Procurement Department \\
\hline GM & - Government Monopoly \\
\hline HAVA & Helmand-Arghandab Valley Authority \\
\hline IDA & International Development Association \\
\hline IDBA & - Industrial Development Bank of Afghanistan \\
\hline MOPH & - Ministry of Public Bealth \\
\hline NCD & - Northern Coal Department \\
\hline NOC & - National 011 Corporation \\
\hline Plan & - First 7-Year Development Plan - 1976/77-1982/83 \\
\hline RDD & - Rural Development Department \\
\hline UNDP & - United Nations Development Program \\
\hline WAPM & - Water and Power Ministry \\
\hline WEP & - World Food Program \\
\hline
\end{tabular}

\section{ABBREVIATIONS}

\section{FISCAL YEAR}

March 21 through March 20

\section{POPULATION}

Throughout this Report an estimate of the mid-1977 population of 14 million has been used. This figure represents the best judgment of IBRD staff drawing on a number of different sources. The derfvation of the figure is explained in detail in Volume II. It should be noted that thts figure differs from what is given In the official ubilications af the 
Syring. The nomads have begun to move their sheep from the winter grazing in the plains, Into the mountains of the Hindu Kush. The snow has begun to melt and the passes of Shibar and Unal will soon be open. The narrow valleys that follow the rivers of the Hazarajat on their course through the mountains, are alive again. The fields are green and heavy with crops and most of the population of the village are busy keeping the birds away from them.

Summer. The wheat has been harvested, and the bazaars are full of fine frults and vegetables. There are melons from Kunduz and grapes from the Kohdaman valley. The weather is hot and dry, and the clties and roads are choked with dust. It is hard to summon up the energy to do more than visit the chaikhana (teahouse) and go over the day's happenings with friends and the occasional passer-by.

Autumn. The flocks and herds are being brought down from the mountalns. The land alongside the roads is filled with nomad tents, and their flerce sheepdogs hark at passing vehicles. The fields are being planted with winter wheat and vegetables and there is a rush to finish picking cotton before the first winter frost. With cooler weather,buzkashi is being played again on the northern plains around Mazar and Kunduz to celebrate the many weddings at this time of year. The villagers and townspeople are stocking firewood in preparation for the long cold winter.

Winter. The passes are closed, except for the Salang, but even there it is necessary to clear the road frequently so that the trucks can pass through with their goods for Kabul or the cities of the northern plain. The tourists have left and Kabul airport stands deserted. The nomads have returned to their grazing grounds in the plains of Turkestan and the deserts of the south. The passes are closed and the valleys of the Hazarajat must wait for the spring. 


\section{A SUMMARY OF THE DEVELOPMENT STRATEGY}

1. In 1971 a World Bank mission wote of the pervasive "disillusionment about the past and pessimism regarding the future" in Afghanistan. 'they concluded that "such pessimism is justified as even in areas where development activities were undertaken, with heavy inputs of capital investment and forefgn advice, returns have been dismally low". Afghanistan was at its nadir. Two years of drought had led to a doubling of wheat frices and large numbers of livestock were being slaughtered. The balance of payments was in dire straits and the Government requested a moratorium on its debt payments. The mission identified four elements which underlay the critical situation; first, the ineffectual administration and the scarcity of competent officials; second, the inability to "devise or follow an effective development strategy"; third, the poor financial management and inadequate tax effort; and fourth, the failure to manage the external sector so as to provide sufficient incentives for exports. The Report states that "This list could be lengthened. Sufficient has been sald, however, to show that there are very substantial obstacles to progress and that those responsible for the conduct of development are certain to be faced with great difficulties in their efforts to proceed effectively and expeditiously. It is clearly impossible to remove all the obstacles in a short period of time".

11. The pessimism of 1971 was not solely a reflection of the weaknesses of the management of the development effort however. There was also a perception of Afghanistan as a country with limited development potential in the longer term. In this respect at least, there is no longer cause for pessimism. In 1977 the economic outlook gives promise that substantial progress can be made in the next ten years towards the goals of higher income levels and meeting the basic needs of the population. Let us spell out the changes which have led to this conclusion. In 1971 it was difficult to identify the elements of a growth strategy for Afghanistan. The major emphasis was on the achievement of food self-sufficiency. The tiny domestic market offered little prospect for industrialization; indeed most of the obvious potentials had been tapped through the large state enterprises which were poorly iun and operating at low levels of capacity utilization. While exports did offer some potential, Afghanistan seemed unlikely to be able to compete effectively given its distance from world markets.

ii1. In the interim major changes have taken place. The harvests of 1972-1976 have made 1 clear that Afghanistan is indeed already self-sufficient in food in normal years. Increased yields are needed not to insure food selfsufficiency in drought years as well, but to enable valuable irrigated land to be diverted to higher value cash crops with export and industrial potential. Food security can be achieved through programs of imports, domestic procurement and storage, so that the economlc 1 mpact of the occasional drought year is minimized. The steady rise in prices of primary commodities, has benefitted Afghanistan's exports. The oil price rise has benefitted nearby markets which Afghanistan is almost uniquely well-placed to serve with agricultural products. A strategy which is led by agricultural exports, increasingly in processed form, has already begun to take shape. Rising prices for minerals 
have made the exploitation of Afghanistan's reserves commercially viable in a number of cases, so that the export drive can proceed along a broader front. The export opportunities are supplemented by good prospects for import substiturion of some 1tems. The substantial inflow of remittances from Af ghan workers abroad should insure buoyant domestic demand in addition to attractive export markets.

1v. This report presents a strategy aimed at exploiting the potentials for rapid growth which are inherent in the new situation. The objective is to achieve relatively rapid modernization, with a wide distribution of the benef1ts, in a manner which 1 s consistent with Afghanistan's untque traditional society, and which is realizable within the constraints imposed by its weak administration. The key to the strategy is the development of an increasing agricultural and 11 vestock surplus which can be processed in part for the domestic market, buz even more lmportantly to supply growlng markets in nearby countries. This would be supported by a limited number of well-managed public sector industries using some of Afghanistan's industrial raw materials. The strategy would imply a considerable decentralization of administration, institutions and investment in physical and human infrastructure since growth would be reglonally spread rather than concentrated in the Kabul area. It would be supported by programs aimed specifically at meeting the basic needs of Afghanistan's population.

v. The strategy for raising ourput rests on the foundation of a rate of growth of the order of 4 percent per annum in value-added in agricultural production. This would break down as a 2 percent per anuum increase in foodgrain output and an increase of 6 percent per annum or more in the output of high-value cash crops such as cotton, sugar-beet, frults and vegetables, and 11 vestock products. The expansion of cash-crop production will permit the development of agro-industries; cotton-ginning and oilseeds, sugar miling, frult and vegetable preserves and canning, dairy and meat products, etc. It will also allow, as mentioned previously, a very rapid expansion in exports of these products to neighboring markets. In order to achieve this $1 \mathrm{t}$ is essential that Afghanistan pursue a pollcy of national food security $1 /$ so that prices for foodgrains relative to other crops remain at levels which permit a modest diversion of the better irrigated wheat lands to these cash crops. Achieving this will depend firstly on a sustained 2.5 percent per annum increase in yields on irrigated wheat lands, and secondly on a program of domestic procurement, imports and storage by the Foc 1 Procurement Department to build up stocks of the order of $200,000-300,000$ tons of wheat for marketing during drought years (see para. 13.20). Curious though 1t may seem, the success of a cash crop production strategy is as dependent on the programs for wheat production and marketing, as $1 \mathrm{t}$ is on the detalled programs for the cash crops themselves.

1/ As explained in Chapter IV, food security $1 \mathrm{~s}$ not synonymous with food self-sufficiency. The former cculd include food imports as is proposed in this case. 
vi. Higher levels of agricultural production depend in turn on inputs and irrigation. The performance with regard to inputs has been creditable to the point where one can see that the continuation of the present growth and improvement of the institutions providing fertilizer, seeds and credit, will serve the needs in these areas. The weak link in the chain is irrigation. Water is the single most important constraint on Afghanistan's agricultural development, yet $1 t$ is being wastefully used through the persistence of traditional systems of water management which are not appropriate to modern marketoriented agriculture. The need to increase water avallability and to make better use of the water which is there, are paramount to the longer term development of agriculture in Afghanistan (see para. 13.24).

vi1. The next step in the output strategy is the development of industries which process agricultural output, provide services to agricultural producers and manufacture the consumer goods to be purchased out of 1ncreased agricultural incomes. This describes the potential for a wide range of products, with small-scale production orlented to local markets; in addition to those meationed above, examples include farm implements, tractor repair shops, furniture, ceramics, etc. Small-scale local production in Afghanistan is almost by definition the area in which the private sector has a major comparative advantage. Yet present policies do not give sufficlent recognition to the important contribution which the private sector could make in the development of these activities. The confidence of the private sector is at a low ebb. The Plan pre-empts, for the state enterprises, a wide range of products sultable for private production. Entrepreneurs are harried by arbitrary tax procedures and a general atmosphere of distrust. Small wonder that private investment in manufacturing has slowed down to a trickle. The public sector is not in a position however, to take up the slack. The managerial experience which is avallable in the state enterprises is stretched to the limit by its present responsibilities, let alone the extremely ambitious proposals in the Plan. The enthusiastic response to a scheme recently introduced by the Industrial Development Bank of Afghanistan, while only a small beginning in itself, is evidence that a program to foster the development of private small-scale industry in Afghanistan could play an important part in the overall strategy (see paras. 13.28 to 13.31 ).

viil. The development of private industry at this stage of Afghanistan's development represents no threat whatsoever to the primacy of state enterprise. The development of public and private industry is complementary. The worrying thing is that the single-minded pursult of state enterprises may steer the Government into large-scale, capital-intensive investments which in many cases do not reflect Afghanistan's comparative advantage at this point in time. The diversion of scarce managerial and financial resources to heavy industries and related infrastructure which promise little benefit for the population during the next ten years, must be the subject of careful soul-searching. The Plan is essentially a project 11st. It contains almost every high priority activity which could be envisaged during the next decade. But it includes many with doubtful economic returns and questionable lmpact on living standards. The danger is that in the context of shortfalls in external finance and limited implementation capacity, the cuts will come in the areas of critical importance, 
while more eye-catching, but less useful projects are retafned. This has happened all too often in the past. The Government should take the InItIative now, to review the Plan and Identify a core of activities which are critical for 8 broad-based development (see para. 13.34).

$1 x$.

When that is done there wil retain a number of well concelved investments in public industry which mer1t support; the explo1tation of the country's coal and copper resources, and parts of the programs for fertilizer, cement and textiles are cases in point. With the continuing expansion of state enterprise, there must be a serious effort to upgrade management practices, especially as they relate to financial operations (see para. 13.35). A second point to be made about the public investment program is that part of it depends on the export of the products of heavy industry in areas where the neighboring countries which are the natural markets, are developing their own production. It w11 be necessary tc secure long-term trade agreements before investments in these areas are undertaken (see para. 13.72).

x. For an optimal pattern of output expansion to take place, the incentive system must provide the right signals to producers and investors. The Government of Afghanistan has an excellent record in this respect. The economy is open, price controls have been kept to a minimum, levels of effective protection are appropriate given the infancy of the country's industry without being excessive, and even the interest rate has been kept at modestly positive levels in real terms. The results have been quite $1 \bar{w}_{t}$ ressive; prices are relatively stable and exports are growing rapidly. There are some worrying signs however. For a number of reasons (see fara. 12.02) there has been a substantial inflow of foreign exchange in recent years and a considerable appreciation of the exhange rate. It is now at a level which is possibly damaging to long-term export growth and the exploitation of domestic import substitution opportunities. Some of the factors, such as remittances, earnings from unofficial trade and capital flight from neighboring coutries, which have contributed to this effect, may not be sustained in the longer term. It is essential to keep the exchange rate under careful review to insure particularly that the promise of an export-led development is not stifled by inadequate incentives (see para. 13.71).

xi. One of the most attractive features of the output strategy proposed is that it will bring added employment and income to the population groups which need it wost. There should be suificient 'trickle-down' that the vast majority will be able to meet those basic needs which can be satisfied through the market; food, shelter, fuel and clothing. Other needs must however be met through public distribution systems and the slow progress in these areas at / present is a cause for serlous concern. The fallure of health and education programs to reach the majority of the population reflects in part general administrative weaknesses, but it is also a consequence of the lack of priority these programs have had in the past and that even whin these programs the objective of meeting the basic needs of the mass of the population has not been given 1 ts due importance. 
xi1. The education sector provides evidence of this. The education system is oriented towards formal schooling to prepare students for the next level. It is not sufficiently related to the needs of the community in general, and the rural community in particular. Even the formal schooling is not cost effective. Coverage remains low and there are large numbers of drop-outs and repeaters. The Government is in the process of carrying out a reform of the education system. There can be no disagreement with the objective of this reform which is to make education in Afghanistan more responsive to the needs and priorities of the national development effort. There are grave questions hovever, concerning the means which have been suggested to achieve this end. For example, it is proposed to increase the average number of years each student spends in school and reduce the size of classes. This will hardly achieve the expanded coverage which is so badly needed, or make the content of what is taught more useful to the lives of the students. In addition, nonformal education has received short shrift in the new proposals. The program in the education sector needs re-thinking. (see paras. 13.40 to 13.46).

xi1. Much of the same limitations are evident in the health sector. The emphasis in health has been on curative medicine - on butlding better hospitals in the main centers. The few who have access to these modern medical facilities return to the same imhealthy environment from which they contracted the disease in the first place. Meanwile the life expectancy in Afghanistan remains among the lowest in the world, with astronomical rates of infant and child mortality. Preventive measures must be moved to center stage. There is no coubt that sanitation, better nutritional practices and above all, clean water, could achieve a dramatic improvement in the situation. Although a start has been made in this direction, these programs are not yet receiving sufficient priority in elther budgetary or manpower allocations. Family planning activities also have an important role to play in improving the health of mothers and children, and merit greater support than they are receiving at present (see paras. 13.47 to 13.52 ).

xiv. In the past, the causes of the inadequacies of the investment program and the lack of success at meeting basic needs, have been laid at the door of Afghanistan's limited implementation capacity. Resources have not been looked on as an effective constraint. This was probably an oversimplification in the past, but it is certainly not the case in the future. The availability of external assistance will be a factor in carrying our the Plan. A new dimension is likely to be added, however, as a consequence of strains in the domestic resource situation. Sources of additional tax revenue appear limited, while expenditure could, and indeed should, increase rapidly, since current expenditures to utilize existing capacity and carry out social programs are of great importance. If legitimate needs are not to be starved of funds, then new sources must be found. Gasoline, for which controlled prices contain only a very small effective tax element at present, is a major potential. There is scarcely a country which does not exploit this as a source of revenues, and in the case of hfghanistan where higher gasoline taxes would scarcely touch the vast majority of the population, this is a curlous anomaly (see para. 13.66a). It is not only gasoline use which is subsidized however. There are a plethora of subsidies covering such items as wheat for civil servants, pocket money for university students, domestic air travel, charcoal 
br1quettes and many more. Msny of these subsidles are given for products or activities which may be expected to expand very rapidly in the medium-term, thus substantially increasing the budgetary drain. These subsidies need to be reviewed and consideration given to withdrawing many of them now, before the political pressures for their retention become too strong. In Afghanistan the incidence of substituting these subsidies by broadened social prog-ams would almost certainly be progressive (see para. 13.66).

xv.

When all is said and done, it is the capacity of the administration to carry out these programs which wll deterulne the poce of Afghanistan's development. So much has been written about the weaknesses of the administration with so little effect that the reader must judge whether we are brave or foolish to raise the subject yet again. Indeed it must be confessed that part of the mission's confidence in the strategy proposed, is that as compared to the past, it is less dependent for 1ts success on the effectiveness of administration, or is more dependent on the areas of administration in which there are proven abilities e.g. the supply of agricultural inputs. To its credit the Government has often been wlling to recognize the limtations and to devise sound policies which do not depend on administrative procedures for their 1mpact. But if there is to be a breakthrough, if the rate of growth is to reach five or six percent in real terms, if basic needs are to be met, then the administration will need to make a far more positive contribution to development than in the past.

xv1. Upgrading Afghanistan's administrative capac1ty w1ll not be an easy task. The salaries of Government officials have fallen by 50 percent in real terms since the mid-60s. This decline has contributed to lower morale and even petty corruption. Increasing opportunities for well-trained Afghan professionals are available outside the country. The main reason to raise salaries however, is not to compete effectively with other opportunities, but to signal to Government officials that they are expected to play a part in the country's development. We regard a substantial increase in government salaries as a necessary condition for any advances in this area (see para. 13:55). But not a sufficient condition, however. That will depend on a lost of reforms in the system under which government officials now operate, and which prevents even those who are motivated from operating efficiently. These reforms relate to personnel policies, budgetary procedures, supply management, auditing and so on. Essentially Afghanistan has a traditional civil service system with emphasis on stopping the wrong things from being cone, at the expense of getting the right things done. This will not be changed overnight, but there are many areas in which action would provide the basis for the confidence and initiative which will be needed for Afghanistan's development (see paras. 13.57 to 13.60 ).

xvi1. One particular weakness in the administrative framework relates to the institutions and personnel for planning. Two decades of technical assistance in the planning field have produced all too little 1mpact. The Plan 1s still essentially a collection of projects which depend on the ava1lability of forefgn financing for their inclusion. It is regrettable when low priority projects for which aid is available are included in the Plan, yet a critical program like road malntenance is only included up to 1980 because there $1 \mathrm{~s}$ 
no forelgn aid committed for 1 t beyond that date. There are many weaknesses in the planning set-up: The Plan is poorly coordinated with the Budget; the Planning Ministry 1tself is under-staffed; the Operating Ministries have very weak Planning Departments which carry little weight within the Ministries themselves; there is no place whthin the system where basic studies on economlc policy can be carried out to provide support to decision-makers; and finally there is a vacuum at the highest levels of economic policy through the failure of the Supreme Economic Council to become an effective entity for taking decisions. Basic changes are needed, not more technical assistance (see para. 13.61).

xvi1. One'strand has consistently emerged from the analysis of problems it every sector the mission has looked at. This is the need for a new emphasis on regional and rural development. In agriculture 1 t is a matter of developing small irrigation structures and feeder roads at the local level, and of giving extension services the incentive and freedom to operate effectively. In industry there is the potential of small local industries and their require ment of adequate power supplies and transport facilities. If they are to succeed. In health and nutrition there 18 the need to reach the rural population and communicate to them the impact which better practices could have on the quality of their lives. This must be supported by the development of banks, schools and health centers at the local level. The development process must be brought cisser to the vast majoricy of Afghanistan's population.

xix. The decentralization of the administrative structure so as to provide financial and manpower resources in the provincial centers is a sine qua non for promoting regional and rural development. In recent years the growth of the Rural Development Department (RDD) has been one of the most encouraging institutional advances on the Afghan scene. The young men who go out into the provinces and 11ve in tents for the two or three months that it takes to complete the work on a small project, are the promise of a different future. The system has not yet dampened their hopes and enthusiasms. There is work to be done. A small culvert is needed here so that the villagers can bring their produce to market. Some minor earthworks are needed there to stop the traditional frrigation structures from being washed away each year. The rural development progran can and should become the cornerstone of a new approach to development based on local participation and responsibility (see para. 13.26).

xox. The Government of Afghanistan has a heavy responsibility. The continuation of the present living standards cannot be countenanced; that only half of those who are born live beyond the age of 5 , and even those only have a life expectancy of 50 ; that $10-12$ percent of the population can read or write; that one-third of the population 11ve in absolute poverty; that in years of drought, widespread hunger visits the land. A commitment to change these things means more than public speeches and impressive Plan documents. It means that solid programs are worked out and that due attention is given to their implementation. We do not ask that "all the obstacles should be removed in a short period of time". We ask for a careful definition of social and economic objectives, and a genuine effort to achieve them. 


\section{PART I: $\quad$ A VIEW OF THE ROAD}

I. THE SETTING

II. THE JOURNEY SO FAR

III. THE ROUTE AHEAD: POPULATION AND INCOME 


\section{I.IE SEIIING}

\section{A. The Land}

1.01 It 1s Central Aa1a. The borders of Afghanistan are defined by the countries which surround it rather than 1ts own geographical unity. The peoples and the terrain overlap with the USSR in the north, Iran in the west and Pakistan in the south and east. The northern border follows the Amu Darya River for part of 1ts way along the plains of Turkestan. The v1llages and grazing lands of the Uzbeks and Turkmans range north from the central mountalns. In the northeast a curlous 180-mile long narrow strip of inaccessible mountains, the Wakhan corridor, forms part of Afghanlstan and gives it a tiny stretch of border with China. It became part of Afghanistan in the 19th century by mutual agreement of Tsarist Russia and Brit1sh Ind1s, so that those two adversarles could avold contiguous borders. The borders with Iran and Pakistan have no natural features to define them and cut across the traditional tribal lands of the Pashtuns and Baluchis.

1.02 Before the opening of the sea route from Europe to Ind1a, Afghanistan was an important crossroads. The anclent $s 11 \mathrm{k}$ road to China crossed the plains of Turkestan, and the caravan route to India lay across the deserts of the south. Trade brought riches and splendor to the c1ties of Balkh, Berat and Ghazni. In recent times Afghanistan has becowe aware of the problems of being a landlocked country, with access to the sea dependent on nelghbors who have on occasion in the past refused transit facilities during periods of hostillty. The nearest port is Karach1 in Pakistan, served by ra1lheads near Quetta and Peshawar. Rarachi is about one thousand alles distant from Afghanistan's capital, Kabul. Overland road and rafl transport to the M1ddle East and Europe takes place through Mashad in Iran or three Russian ports on the Amu Darya River.

1.03 It is convenient to divide the country 1nto four major geographic zones: the northern plains; the central mountains; the eastern and southeastern mountains and foothilis; and the southern and western lowlands. In the north of the country lie the plains of Turkestan. Much of this area is relatively low, about 1,200 feet, though the altitude rises rapidly in the foothills which approach the central mountain region. The climate is characceristic of Afghanistan, cold winters with perhaps thre. to four weeks of freezing temperatures followed by variable spring weather with thundershowers and hot, dry summers with temperatures up to 40 degrees C. Annual rainfall seldom exceeds $25 \mathrm{~cm}$. The population is largely Taj1k in the large towns such as Mazar-1-Sharff and Kunduz in the central and eastern parts of the plain, and Uzbek villagers and nomads further west. Other groups including Turkmans and Pashtuns are also well-represented, however.

1.04 The plains of the north are separated from the rest of the country by the great ranges of the Hindu Kush. These extend from the Pamir in the extreme northeast and dominate the central and eastern parts of the country. In the central mountains the peaks range from 14,000 to 17,000 feet and even the valleys 11 e at 9,000 feet. This beautiful inhospitable area is peopled 
by the Hazaras, and the region derives its name, the Hazarajat, from them. That the valleys were once $r$ ich and powerful is evidenced by the remarkable Graeco-Buddhist monuments at Bamian, and the minaret of Jam. In the summer months, the nomadic tribes, the Dzbeks from the north and the Pashtuns from the south, bring their flocks into the mountains of the Hazarajat. In the wnter the snowline creeps down to about 6,000 feet and the passes of Shibar and Unal are closed for much of the time. The north of the country would indeed be cut off for long stretches were 1t not for the Salang Pass which was completed with USSR assistance in 1963.

1.05 The mountains of the Hindu Kush seem during the course of history to have represented a challenge rather than a deterrent to the many invaders who used their passes to cross from central Asia to the Indian sub-continent. The passes command the cities and valleys of eastern Afghanistan. The valleys are at elevations of 4,000 to 7,000 feet. Kabul, the capital city, lies in the widdle of a string of rich valleys which are well able to support 1ts large population. Jalalabad, which is situated to the southeast at a lower altitude, has a warmer climate. The road to Peshawar and the interior of the Indian sub-continent goes from Kabul through Jalalabad and over the Khyber Pass. Afghanistan's only major forested areas lie in this region. The first of these is Nuristan, the land of 11 ght - the name was changed from Kafiristan after its inhabitants were forcibly converted to Islam in the $1890 \mathrm{~s}$. Nuristan is inaccessible and ethnically quite separate from the rest of the country. A second region of forests is in Paktia in the south, the heartland of the Pashtum tribal culture.

1.06 The main roads from Kabul link each of the major regions to the capital. Northwards the road runs over the Salang Pass to Mazar-i-Sharif, eastwards to Jalalabad and Peshawar, westwards an unpaved road rums to Bamian and into the interior, and southwards the road goes through Ghani and on down to Kandahar and north again to Berat. The last mafor reglon, the southern and western lowlands is the largest and comprises the valleys of two major rivers which rise in the Hindu Kush, the Belmand and the Hari Rud, and also the large, sparsely inhabited desert of Registan. Much of this area lies between 1,000 and 3,000 feet. It is far hotter and dryer than the rest of the country and summer temperatures of 45 degrees $C$ are not uncommon. The area is mainly inhabited by Pashtuns.

i.07 A mere description of the regions however, 15 not enough to give the reader an understanding of how crucial the geography and topography of Afghanistan is to its people and 1ts economy. For that one must see the raging rivers of spring that wash away roads, bridges and canals, yet dwindle to narrow channels or a series of unconnected pools by autum. One must see the narrow valleys of the Hazarajat, with every inch of their floor under crops and the rocky mountainsides being crossed by sma 11 flocks of sheep and goats. One must see the deserted ruins of Bost in the dusty plains south of Lashkargah. Perhaps most of all one must see the Hindu Kush and among those snowcovered peaks, recall that fierce, gentle ruler, the Emperor Babur who called Afghanistan the theater of heaven. 


\section{B. The People}

1.08 Afghanistan is 250,000 square miles in size, about the size of Burma or the state of Texas. Its population is perhaps $14 \mathrm{million}$, of whom roughly 10-10.5 million are settled villagers, 1.5 million are nomads and $2.0-2.5$ million live in urban areas or in the smaller market towns. The population is made up of a number of different tribal groups; $1 \mathrm{t}$ is officially estimated that the largest single group is the Pashtuns, followed by Tajiks, Uzbeks, Hazaras, Turkmans and a variety of other groups. There are wide variations in racial characteristics and it is not possible to generalize these into an Afghan stereotype. There are a number of unlfying features however, beyond those of a common territory and goverament. Thus the population is almost entirely Muslim with almost all groups other than the Hazaras belng Sunnites. There are two dominant languages, Pashtu and Dar1, and one or other, or of ten both, are spoken by most of the population. There are many other common features related to the way of social and economic life in the thousands of villages that dot the countryside.

1.09 The basic unit of Afghan life is the village, of which there are about 20,000. Even the nomad camps can be viewed as moving villages. Single villages may range in size from as few as 10 farming families to as wany as 500. It is not possible to identify a typical size within this range, though perhaps the largest number of villages would fall into the range of 40 to 80 families. The villagers are linked by ties of marriage and kinship. There are three important 'officials' in the village who are chosen by the inhabitants. The first of these is the malik or headman of the village. He is responsible for the dealings of the village with the government or outsiders. The second is the mullah who leads the religlous life of the village and instructs the young in the religion. The third is the mirab or water master who organizes the village irrigation system and the work which must be done to keep it in operation. These village leaders are extremely influential and their support has been in the past, and will continue to be in the future, the key to any constructive changes in the village environment.

1.10 The village economy revolves around land and water. About 60 percent of the land is farmed in holdings of under 20 ha each. These constitute 98 percent of all farms, including 40 percent which are less than 0.5 ha. Approximately half of the landholdings are too small to provide a living and their owners must supplement their incomes. This might be done in part through livestock, handicrafts and trade, but in most cases vould mean taking employment as casual laborers and sharecropping on larger farms. Sharecropping in Afghanistan takes two forms: either the sharecropper supplies only his labor and recelves one fifth of the crop, or he provides inputs such as seed, implements and draught animals, and receives one half of the crop. Such arrangements are an obvious disincentive either to 1nvestment by the landlord, or the use of more costly inputs such as chemlcal fertllizer by the sharecropper. Another problem related to landholding in Afghanistan is that of fragmentation, which results from the laws of inheritance with prescribed shares for all the surviving family members. The absence of an adequate system of recording land titles results in frequent, and other violent, disputes over land ownership. 
1.11 As in many other ar1d countries, water is the key to life in Afganistan. Of the country's area, only about 12 percent is cultivated, minly because of the shortage of water. About one sixth of the cultivated area is dry-farmed land on which wheat and barley are grown, but in drought yesrs such as $1970, ' 71$ and '77, production on the dry land is negligible. For the irrigated land, water is drawn off directly from the rivers where the land is fairly level as in the northern plains. In other areas however, a remarkable traditional irrigation system, the karez, is used. The karez is an underground tunnel which intercepts the rising water table as the land slopes upwards away from the river bed. When the water flows out, the tradition is that the users upstream have priority over those downstream - an allocation system that has the virtue of ease of administration if not those of equity or efficiency! $1 y$

1.12 Moving from the economic life of the village to its social life, it is important to impress upon the reader that Afghanistan remains a very conservative, traditional Muslim society. Nor is there evidence that outside of the 700,000 inhabitants of the capital city, this is changing or breaking down. The economic developments of the past two decades have either left the villages untouched or have been consistent with its social traditions. But this will not always be so. The Government's present plans for implementing land reform, proposals for rationalizing water use, iucreased educational facilities particularly for women - all these represent a challenge. For most of the villagers or those who live in the small towns however, change seems far away. Indeed change 1tself is not a concept which is really assimilated into the Afghan contaxt. Notions of progress towards higher living standards are confined by the needs and values of the village. To an Afghan farmer better life may mean more wives, more sons, a larger living area with carpets on the floors and perhaps better clothing and a transistor radio. Since no villages have electricity and few are linked to motorable roads it is understandable that the horizon should be so limited.

1.13 Perhaps the key is lack of education. Only 10-12 percent of the population of Afghanistan is literate and in many villages only the mullah of the older generatior will be able to read or write. Of the children of primary school-going age about 30 percent attend school and in all areas other than Kabul province only 25 percent. Of girls of primary school-going age less than 9 percent attend school and in areas other than Kabul province only 5 perceat. There is as yet little awareness that ft is not simply the will of God that 50 percent of children should die before the age of 5 years, or that even those who attain that age only have life expectancy of 50 . These figures probably represent an improvement over the past, yet not enough so that there would be awareness of change. For the most part, life in rural Afghanistan is much the same as it would have been centuries ago.

1.14 "The village of Ri-Jang lies about 20 kilometers south of the large city of Mazar-i-Sharif in northern Afghanistan. It comprises 224 inhabitants living in 42 households. Its existence centers around agriculture which is at

1/ This tradition does not follow Islamic law. The spirit of the Shariat is that water should be allocated according to acreage of arable land. 
the mercy of the rains. In years of poor rainfa11, their wheat crop is only half the average, in good years double. The village receives little water from streams and the little it does goes to satisfying personal needs and irrigating small personal orchards and gardens. In a typical year over 65 percent of total income is from dry-farmed wheat, about 23 percent from 11 vestock, 2 percent from the frrigated gardens, and the remainder from casual labor. But income and wealth in Ri-Jang are distributed very unequally: the wealthiest 8 families own 78 percent of the goats and sheep, 65 percent of the land and earn almost 65 percent of the total income; while the poorest 22 famlies own less than 5 percent of total goats and sheep, only 13 percent of the land, and earn only 15 percent of the total income. Although only 3 families own no land at all, all of the poorest 22 families cannot make enough to subsist on from their own land. Hence more than half the wheat they produce is from sharecropped land. They are also forced to supplement their incomes by hiring out their labor, and by carrying snow in the summer and bushes in winter down to Mazar-1-Sharif on the donkeys most of them own. Almost half their income comes from these sources. Health in Ri-Jang is poor: 38 of the 42 households drink heavily polluted water that flows through the village in an open canal, and 4 households eat meat less than once a week. When a foreign doctor visited the village, 129 people came to him, many with several ailments. More than 10 percent were anemic, 15 percent had major digestive ailments, 15 percent had respiratory problems ( 4 had TB), and more than 20 percent (most lv childrea) had confunctivitis. Only 20 people in Ri-Jang are literate, including only 1 woman. There is a village school for boys the villagers themselves paid to build and staff. The school now stands empty - villagers are disillusioned with the school system that they felt tried to get their children to leave the village for the city and didn't teach children to read and write nearly as we 11 as the mullah did." I/

1.15 Muheb All is a farmer, His village, Alchin, has about 40 families and is situated $10 \mathrm{mlles}$ west of Bamian in the Hazarajat. He owns 4 jeribs of land (about four fifths of a hectare). The land is irrigated with water from the river that runs through the narrow valley and he grows a single crop of wheat on it, which yields 30 seers (about $210 \mathrm{kilos}$ ) in total. He uses this wheat entirely for subsistence consumption by his family which consists at present only of his wife and 25-year old son. He has four married daughters. Another five children have died. He owns a metal-tipped plough which he purchased two years ago for Af 450 , and a pair of oxen each costing Af 8,000 . In addition to his land he also owns a small flock of 35 sheep and 4 cows. His son takes the sheep into the hills to graze. In addition to the produce which the family obtains from the sheep and cows, he sells four or five of the sheep (receiving about Af 1,000 for each) each year. He once owned a donkey, but it died. Muheb Ali uses no chemical fertilizer on his wheat and has never been visited by an agricultural extension officer. His son never went to school and he has never visited a hospital or been beyond the town of Bamian in his life.

1/ Source: CINAM, Services for Children within Regional Development Zones Research and Action. Experimental Activities at the Village Level, Vol. II Monographs. UNICEF, Kabul, July 1973. 
1.20 Abdel Karim is a member of the civil service. He presently holds the rank of a General Director in a Ministry, at a salary of Af 4,200 a month. This salary is far too low for him to make ends meet in Kabul even though it is supplemented by a subsidy for purchase of flour. Fortumately he comes from a wealthy and large family which owns considerable land so that he 18 not dependent on his salary for living. Bis father died a few years ago and he is now the head of the family. He has bullt a large house at a cost of nearly Af $1 \mathrm{mlllion}$ in Shar-1-nau (the new city), the most modern and fashlonable suburb of Kabul. He has a car, but the house itself is sparsely furnished - mainly large numbers of carpets on the floor and cushions for reclining. The large reception room for guests has an airconditioner however. He has only three children, and does not plan to have more though be comes from a famlly of six. He married when he was 16 and his wife 15 and met for the first time at their wedding. He did graduate studies overseas and has ambitions to return overseas at some later point of time to continue his studies or take up employment.

1.21 The final population group which needs to be described, and perhaps the most fascinating, is Afghanistan's population of 1.5 to 2 million nomads. The majority of the nomads are Pashtuns though there are also groups of Turkmans, Dzbeks and Baluchis. They move from winter grazing in the plains and lowlands to summer grazing in the foothills and the Hindu Kush. They travel in groups with their flocks and tents, stopping for a few days at a time at traditional camping grounds. Over time an interdependence has developed between the nomads and the sedentary population in the rural areas. In the past aomad traders brought with them kerosene, matches, cloth, sugar, tea and spices. Now their trade is largely confined to livestock products. In exchange they get grains, fruits and vegetables from the farmers. They also provide farm labor during the peak seasons of the year and the wealthy nomads are important moneylenders and landowners. During recent years an increasing number of noms ds have purchased land and created a home-base for themselves while still continuing on their annual journeys with the flocks. A caravan of nomads is a stirring sight - so 1 t must have been in the days of Genesis. Development economics has i1ttle advice to offer on the question of how to improve the lot of the nomad, short of destroying a unique way of life.

1.22 It is oversimplifled, but nonetheless useful to think of Afghanistan at present, in terms of two societies - a traditional one for the 85 percent of the population who form part of the rural economy and a modern one for the 15 percent who live in the towns. There ald however, increasing links between these two sectors as the Government pursues its objectives of expanding the modern economy. There is the rapid spread of nontraditional education to the rural areas, increasing health facilities and disease eradication, cash-crop production stimulated by the effects of government agencies for the distribution of seed, fertilizer and credit, improved communications through roads and the ubiquitous transistor radio. Looked at from the standpoint of the towns and the modern sector these changes appear minimal, but from the standpoint of the village they sometimes appear rapid and unsettling. 
The Structure of the Economy

1.23

If one combines agriculture, livestock, handicrafts and rural trade under the heading of the traditional economy, then 85 percent of the population of Afghanistan (1ncluding the nomadic population) would probably be primarily dependent on these activities for their livelihood. The rest would consist aninly of the government administration, the industrial sector, urban trade and courism and the transport sector. Total GNP in Afghanistan in 1976/77 was of the order of Af 115 billion wh1ch translates to GNP per capita of Af 8,200 or about $\$ 180$. Sectoral breakdowns of Net Domestic Product and the economically active population is shown in Table 1 below:

\section{- Table 1: NDP AND ECONOMICALLY ACTIVE POPULATION (1975/76)}

\begin{tabular}{|c|c|c|c|c|}
\hline 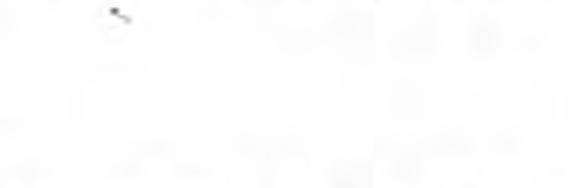 & $\begin{array}{c}\text { Af } \\
\text { bil11on }\end{array}$ & $\begin{array}{l}\% \text { of } \\
\text { NDP } \\
\end{array}$ & $\begin{array}{l}\text { No. of } \\
\text { Persons } \\
\text { Employed } \\
(\mathrm{O} 00) \\
\end{array}$ & $\begin{array}{l}\% \text { of } \\
\text { Total }\end{array}$ \\
\hline Agriculture and Livestock & 53.81 & 55.4 & 2492.8 & 52.9 \\
\hline Handicrafts & 7.70 & 7.9 & 843.6 & 17.9 \\
\hline Industry and Mining & 3.40 & 3.5 & 40.7 & 0.9 \\
\hline Construction & 2.17 & 2.2 & 44.7 & 0.9 \\
\hline Transport and Communications & 3.46 & 3.6 & 56.6 & 1.2 \\
\hline Commerce & 11.82 & 12.2 & 257.3 & 5.5 \\
\hline Services & 8.64 & 8.9 & 691.6 & 14.7 \\
\hline Other & $6.091 \mathrm{~s}$ & 6.3 & 282.7 /b & 6.0 \\
\hline TOTAL & 97.09 & 100.0 & 4710.0 & 100.0 \\
\hline
\end{tabular}

la Includes housing.

$\underline{t b}$ Includes unemployed which amounts to 2.7 percent of the total labor force.

Sources: Ministry of Planning, Afghan Demographic Survey (ADS): National Demographic and Family Guidance Survey of the Settled Population of Afghanistan, and Mission estimates.

1.24 Agriculture constitutes the mafor economic resource providing a source of living for the majority of the people and contributing over 55 percent of NDP. Only about 12 to 13 percent of the land is cultivable, of which half is cropped each year, while as much as two thirds of the country provides some winter and summer graz1ng. Only 3 percent of the land is classed as forest. Two thirds of the cropped land is irrigated and accounts for the greater part of production. Wheat occupies most of the rainfed arable land giving average yields of only about 0.5 tons/ha but there has been complete failure of the crop in drought years. About 50 percent of the irrigated land is under wheat and a further 30 percent under maize, rice and barley, with the balance mainly cropped with fruits and vegetables, cotton, o1lseeds, sugar beet and forage legumes. Average yields are low, as little improved seed is available and chemical fertilizer is applied to only about one elghth 
of the irrigated land. As discussed in para. 1.10 above, the overall farming pattern is of very small holdings typically of 2 to 4 ha though many are under 0.5 ha and their owners have to supplement their incomes by working as laborers or sharecroppers on larger farms. A million oxen provide practically all draught power on the farms, averaging about one animal to a holding. Larger farmers, who are finding casus 1 labor less readily available than in the past, are increasing mechanization though as yet there are only about 3,000 tractors in the whole country.

\subsection{An1mal husbandry in Afghanistan is almost entirely taken up with} extensive pastoral management of flocks of sheep and goats, wth cattle maintained in the irrigated areas primarily to provide work oxen. Thus livestock of some kind are to be found on practicaily all farms, large or small, and in total contribute about a quarter of agricultural NDP. While husbandry techniques are well adapted to the harsh environment, productivity is low as facilitles for disease prevention and parasite control are lacking. The general low level of nutrition with inadequate supplementary feed, due to primitive methods of fodder conservation and the acute shortage of standing feed in winter, results in high mortality rates especially among sheep and goats. The national livestock population is estimated at about 20 mllion sheep and goars, of which about 25 percent are Karakul and 20 percent are goats, and 3.5 milHon cattle. Donkeys, horses, mules and camels, on which farm transportation and the movement of the nomadic population are dependent, make up another 2 million head.

1.26 Handicrafts play an important role in the Afghan economy, contributing about 7 to 8 percent of NDP and employing about 18 percent of the labor force - substantially larger shares than modern industry and mining. About two thirds of the handicraft workers are women. The major types of handicrafts are carpets and rugs, embroidered textiles and leather goods, wood and stone carvings, cerautcs and jewelry. Of the various types of handicrafts, carpets and rugs are the best known and the most 1mportant; they are hand-woven and their traditional tribal designs have in recent years found a great deal of favor in western markets. Carpets are woven on simple wooden frames by the women and chlldren of nomad tribes or villages. Much of the work is done during the long winter and the income forms an important supplement to the family's other earnings. The potential earnings from carpet-weaving are often a substantial consideration in the dowry which must be given to the bride's famil $y$. The market for many of the traditional crafts is increasingly abroad and this is likely to 1 mply a greater emphasis on quality materials and finish than in the past.

1.27 Although the first private industrial enterprises vere established in Afghanistan during the 1930s, the majority of undertakings are of recent origin, and a high proportion were set up in the period between 1965 and 1972 . There are now about 130 'medium-scale' establishments, employing about 10,000 persons. In addition there are a large but unknown number of artisans in Kabul and the other major towns. Private industry is concentrated in the production of light consumer goods for the domestic market, mainly cotton and rayon textiles, leather and footwear, pharmaceuticals, food and beverages. In 1975 the major commercial bank, Bank-1-Melli was nationalized, with the result that 
a nuber of private enterprises in which it had a majority shareholding became part of the public sector. The nationalization, combined with uncertain:y bout the post-1973 Government's attitude to private enterprise, has contributed to a marked slow-down in the pace of new private investment in the Industial sector.

1.28

The present constitution reserves heavy industry for the public sector. A number of state enterprises or tasadys were established in the late $-50 \mathrm{~s}$ and early $60 \mathrm{~s}$. These include enterprises producing cement, engineer$1 \mathrm{~g}$ products, sugar and textiles. More recently there has been a major investment in fertilizer production. The state enterprises were set up at a t1me when the indigenous managerial base was extremely weak and progress in this direction has been disappointing. Thus there is practically no state enterprise which keeps meaningful and up-to-date financial accounts and as a result assessment of their performance and delegation of control to their management has not been 1 mplemented effectively. The public sector industries account for a disproportionately large share of industrial investment and a disproportionately small share of industrial value-added and employment.

\subsection{Mining in Afghanistan is entirely in the public sector. The major} resource which has been exploited so far is natural gas. The gas has been developed with Russian assistance and most of the annual production is piped to the Soviet Union. Afghanistan currently earns about $\$ 50$ million a year from these exports. The natural gas is also being used for fertilizer production. Exploration for petroleum is proceeding though success has been $11 \mathrm{mited}$ to date. Afghanistan has substantial coal resources of which only a small amount has so far been tapped. Coal represents a major potential but serious managerial problems will have to be overcome first. There are also large deposits of Iron ore located at Hajigak in the Koh-i-Baba range at altitudes of over 12,000 feet. The exploitation of these will depend on the feasibility of large-scale mining and transportation given their inaccessibility. There are copper deposits at Ainak which also have considerable potential. Both Hajfgak and Ainak are presently at the study and design stage.

1.30 The transport system consists mainly of the road network. Considering Afghanistan's rugged terrain and climatic extremes, which result in very high costs of construction, the primary road network is relatively well developed although some areas remain to be covered. The highway system liniks the main agricultural areas and population centers through circling the central mountalns, anc Linking Kabul with Baghlan and Mazar-1-Sharff in the north, Kandahar in the south and Herat in the west (see Map No. IBRD 13204). Outside the main roads however, the quality of the system falls away rapidly - the huge central region of the Hazarajat does not have a single paved or allweather main road for example, and consequently is inaccessible for much of the winter and spring. Domestic civil aviation is very limited but nonetheless serves a useful purpose in providing access to certain remote areas with poor or non-existent road connections. No raflways exist because the mountainous terrain makes construction too difficult and expensive, while the volume of bulk products for long distance hauls is not significant at present. 
1.31 Other forms of physical infrastructure are not highly developed in Afghanistan at present. Electriclty consumption per capita is among the ten lowest countries. About 5 percent of the population has electricity for domestic use, and even then, in many cases supply is confined to certain hours of the day. There is virtually no electrification in the rural areas. Total capacity is $318 \mathrm{MW}, 60$ percent of it in the Kabul area. Over 90 percent of the present system is based on hydro resources. Piped water supply is similarly confined to the urban areas and the proportion of the population served by these is similar to the 5 percent for electricity. Indeed for the most part these groups are the same and over half of them are in the capital city. With regard to communications, there are about 26,000 telephones in Afghanistan (less than 2 for every 1,000 persons) and about 300 post-offices.

1.32 The availability of trained manpower has been and remains one of the major constraints to Afghanistan's economic development. There are shortages of trained manpower in many skill categories as well as for most middle and higher level technical positions. In some areas such as accounting there are virtually no trained local personnel available and training has only just commenced. Kabul University has an enrollment of about 12,000. It does not offer post-graduate training, but a large number of Afghans have received such training abroad. Many of these, however, have taken up employment elsewhere, partly in response to the very low salaries offered in government service in Afghanistan. Since 1974 employment opportunities for all categories of workers, unskilled, skilled and professional, in Iran and the Gulf countries, have led to a further exodus. It has become not merely a question of how to train adequate numbers of Afghans, but also how to motivate them to remain and participate in Afghanistan's development effort.

1.33 In addition to looking at the economy through snapshots of the major sectors it is useful to analyze it in terms of categortes of expenditure. Inevitably such an analysis is heavily dependent on the avallability of reliable quantitative information. While information on the public sector and the external sector is reasonable, any quantification of private sector activities is pure guess-work. There is sufficient qualitative and partial information however, to enable the judgment to be reached that the levels of investment and savings in Afghanistan are well below those of other countries with comparable levels of per capita income. A possible conformation of expenditure is shown in Table 2 below.

Table 2: EXPENDITURE ON GDP $(z)$

$\underline{1975 / 76}$

Total expenditure on GDP at market prices 100

of which:

Private consumption

Government consumption

Gross investment - Private

- Government 6

Exports of goods

Less Imports of goods 
1.34 Privace consumption is determined as a residual in Table 2 , and its level therefore is of little interest. Something can, however, be said about its composition. Thus about 60-65 percent of expenditure on private consumption is for food, of which approximately one-third (1.e. 20 percent) is probably in the form of subsistence production. Of the remainder, fuel, particularly firewood, is of great importance in Afghanistan's cllmate and probably matches the share of clothing, each being around 8 percent of the total. In the larger cities of course there is a vide range of imported consumer goods avallable for the middle class. In the smaller toms and villages however, the local trader generally carries a limited 11st of items; kerosene lanterns, cigarettes, matches, soap, aspirins, batteries and perhaps transistor radios, paper, pencils and pens, metal utensils, etc.

1.35 While the level of gross investment in the private sector is not much below that of the public sector, the difference would probably be more marked for net investment. A high proportion of private investment is for maintenance; house repairs and maintaining irrigation channels. Net investment consists of the tiny medium and small-scale industry sector, a small amount of farm mechanization, the purchase of trucks and heavy vehicles, some small onfarm 1mprovements, the planting of orchards, and fattening of sheep and goats and expansion of flocks. The total net investment has probably changed little ard may even have fallev since the late $60 \mathrm{~s}$, although the official series suggests an increase. The low level of private investment does not appear at this point in time to reflect a shortage of investible resources in the private sector. Increased money incomes in the rural sector in recent years have not flowed into investment, but have either been spent on a limited range of consumer items or have been hoarded. Bank deposit rates of 8 percent (slightly above the rate of inflation) have failed to attract income earners to transfer their resources to the financial intermediaries. Yet the riddle is that these same farmers respond rapidly to changing incentives embodied for example in the relative price ratio between wheat and cotton, and that moneylenders, who charge usurious rates of interest, thrive in the rural areas. It is possible to identify two sources of the reluctance to invest or to save in financial form. First is the lack of awareness of potential opportunities and the return from explolting them. This is traceable to the weakness of the educational effort, the shortfall in all forms of extension and the $11 \mathrm{~m}$ ted reach of the media - in short the failure to communfate the potentials to the population at large. A second problem which deters even those who are aware of the poteatials, is that the average villager or townsman sees little tangible benefit from involvement with government-related officials and agencies. Clearly these two points are not unrelated - effective education and extension by honest and competent government officials will be a primary component of building confidence in the Government and its intentions.

1.36 The distinction between government consumption and investment in Af ghanistan is less important than in many developing countries. It could be argued that the current components of expenditures on education and health have a greater developmental impact than anything in the investment program. Only 10 percent of toral government expenditure goes for current expenditure on education and health, representing less than 2 percent of GNP. Nor are other 
components out of line Sor a country of Afghanistan's size and income level. It is apparent that increases in current expenditure will be critical to the future development effort.

1.37 Much the same observations could be made about government investment. The level of this investment has depended very largely on the availauility of forelgn assistance and Afghanistan's capacity to absorb it in the form of investment projects. For much of the past, the avallability of foreign aid seems to have been slightly higher than the capacity to use it for projects yiglding acceptable returns. The sectoral composition of investment has also depended on donor interests, though the Government has had some influence in this area. Thus there was emphasis on infrastructure and public industry in the late 50 s and early $60 \mathrm{~s}$, which shifted somewhat to agriculture in the subsequent period. Frequently, however, the investment Plans which have been prepared, often with foreign technical assistance, have not been adhered to because of the absence of well prepared projects to give content to the good intentions. Because of the lumpiness of major projects, the composition of investment varies considerably from year to year. On the average however, it probably comes close to a structure of three equal parts: agriculture and irrigation; industry and mining; and transport and power. Other sectors would account for perhaps 10 percent of the total.

1.38 Perhaps the most salient feature of the fiscal system in Afghanistan is its small size. The tax to GNP ratio is 7 percent, nearly the lowest in the world. Adding in other domestic revenues does not change this picture. Notwithstanding the minute quantity of resources mobilized, the Governmeni consistently runs a current account surplus which is used to finance development expenditure, although well over two thirds of such expenditure is funded through forefgn aid. As a consequence ordinary expenditures are also extremely low and, as mentioned above, there is a grievous shortfall in providing the most basic public services such as control of commicable diseases or primary education. Over two thirds of all taxes are on forelgn trade, an extremely high ratio. The country is also extreme in its fiscal centralization. The provinces have no tax authority and no budgets, and the resources marshalled by the 87 administrative units classified as municipalities are very meager, less than 1 percent of GNP. Notwithstanding the leading role of state enterprises in the modern economy, they contribute very little to the public revenues. Actually their subsidization may have exceeded their transfers to the Government - as mentioned in para. 1.28 the state of accounting is so poor that it is difficult to reach a clear conclusion on this.

1.39 Banking in Afghanistan is inchoate. There are three commercial banks and three specialized banks, all publicly owned. The central bank's (Da Afghanistan Bank) activity is largely limited to management of the stock of money and of the government accounts as well as limited intervention in the foreign exchange markets. Commercial banking is extremely centralized in the capital. Although branches exist in the provinces, their functions are very limited. In many towns their chlef activity appears to be that of providing a safe place for holding funds. All loans are made in Kabul. In 
spite of an early experience with investment bankirg, most bank credit is short-term loans. Of the three specialized banks the Agricultural Development Bank of Afghanistan is perhaps the most dynamlc. It has provided tens of thousands of fertilizer loans in financing the Government's effort to introduce new inputs into agriculture. Given the rudimentary nature of formal banking, it is not surprising that the bazaar money traders, and above all those of sabul, play a major role particularly in financing foreign trade. They may dccount for nearly two-thirds of annual turnover in forelgn exchange. In addition the bazars finance consumer loans, working capital, housing and ther construction, and even longer term industrial undertakings. Possibly, sazar intermediation is a more important source of finance than the formal institutions.

.040 Turning to the external sector, the share of trade remains less chan 15 percent of GNP. In sowe ways even this figure overstates its role in the Afghan economy. Afghanistan has never been a major supplier of cash crops ir minerals to foreign markets in the way that other countries of comparable ize such as Sri Lanka, Malaysia or Chile have been. Neither 1ts modern sector nor its infrastructure evolved to supply primary products to foreign arkets. It has been a traditional crossroads of trade routes and even today $t$ plays an entrepot role with respect to goods which are imported and then re-exported, often illegally, across the long borders with Iran and Peklstan. Its import needs for consumption have been $11 \mathrm{mi}$ ted in the past - textles, ea, sugar and petroleum have been the main 1tems, and there has often been - perception of exports as being conventent means of disposing of surplus domestic production rather than an intrinsic feature of the economy.

.41 Afghanistan has developed a fairly diversified export structure. A number of agricultural products are exported; fruits and nuts, ginned cotton, 'srakul pelts. These comprise about 60 percent of the total. Handicrafts Jmprise about 12 percent of which two thirds takes the form of carpets and rugs. A further 12 percent is accounted by natural gas exports to the USSR and the balance of 16 percent covers a large number of smaller items. With ?gard to imports the four major items cited in para. 1.40 above, still com":ise over 50 percent of the total. Capital goods, related to projects and financed by foreign aid, account for about 20 percent of the total. All these -gures however, reflect the official trade data. The long rugged borders, cossed by traditional tribal grazing routes, make smuggling almost inevitable when relative prices between Afghanistan and its neighbors get out of line. Thious narcotics control agencies have also claimed that there is smuggling : drugs out of Afghanistan at present.

1.42 Although there is a chronic recorded trade deficit, in practice the ghan economy has been able to finance this through ald inflows averaging - jout $\$ 65$ million a year and substantial remittances from workers employed since 1974 in Iran and the Middle East. The result has been a buildup of : serves to about 80 percent of the annual import of commercial goods (1.e. ( scluding imports under ald). The Government has followed a very conservative approach to financing investment in the past and has rarely allocated its nwn foreign exchange when there has been a prospect of securing aid for the pur1 ise. This approach had 1ts roots in the pessimistic out look for Afghanistan's 
balance of payments, which prevalled prior to $1974,^{\circ}$ and also the necessary association of foreign donors in the technical assistance effort which remains a major feature of projects in Afghanistan.

1.43 No review of the economy of Afghanistan would be complete without some reference to the role of the Government in economic management. Unt11 25 years ago, traditional Afghanistan was a society in equilibrium. High birth rates were matched by high death rates. In good years there was food for all and more, in bad years scarcity and occasionally starvation. There was little migration from the rural areas. The traditional sector produced enough agricultural products and handicrafts to 1nsure an adequate supply of the major imports - tea, sugar and text1les. In 1953, the then Prime Minister Mohammed Daoud Khan ushered in a new era in Afghanistan, by essentially introducing the notion that the Government was responsible for transforming Afghanistan into a modern society. Although Afghanistan remained a mixed economy, the motive force was clearly percelved to be the state.

1.44 The state is of course an abstraction. Its practical embodiment is the political leadership and the government administration. The administration had previously been little more than the staff of the King and the Prime Minister. It would have been impossible to have turned it into a modern development administration overnight and the inftial steps in development had to be taken largely through forelgn assistance. This assistance was partly Einancial and partly through a substantial technical assistance contribution, quite possibly the largest undertaken $1 \mathrm{n}$ any country which did not have a colonial association. In subsequent years, the administration was gradually upgraded and has taken over many of the tasks performed by foreigners previously. The administration remains however far from what would be implied by the need for a coherent, well administered development effort, and the input from foreign technical assistance remains very large relative to Afghanistan's size and resources.

1.45 Afghanistan can be characterized as a mixed economy. The traditional economy is of course totally private, but the modern economy is dominated by the state. The major industries, other than textiles, are publicly owned and managed; the banks, much of the tourist 1ndustry, certain major trade 1tems, etc. are all in the public sector. Even in agriculture, some state farms have been established with assistance from the USSR. But the role of the state goes further even than that. Education in Afghanistan is highly subsidized and this applies to all levels. The graduate is in a sense committed to the public sector after qualifylng and even more important, the state is committed to finding employment for him or her. There is an implication of people belng drawn out of the traditional private sector and recruited into the modern state sector.

1.46 There is a constant tension in Afghanistan between the very great responsibility that has been given to the government administration in running the modern economy, and the ability of both the personnel and the system in which they operate to provide the quality of service which is needed. A number of examples will indicate what is meant. Large-scale modern industries need proper financial management, but there are no trained Afghan accountants and 
cbus none of the public enterprises is able to produce meaningful and timely leancial statements. The system of auditing is geared entirely towards concrol in the narrowest sense of the word. Thus recently a Government official lound that he could not secure labor at the officially stipulated wage rate so be took the initiative of exceeding the out-of-date guideline and was thereby able to finish the profect ahead of time and well under the total budgeted cost. He was prompty reprimanded for exzeeding the officially stipulated wage rate. Other classic examples relate to the system of warehouses for government ctores which are operated by a bonded store helper, the tahwildar. If the cahulldar is sick or out of town there is no way an 1tem can be released from the steres no matter how urgent. Stories are commonly told of tahwildars wo are in jall and have to be solemnly marched over from the jail whenever anything is needed from the store. These examples could be multiplied.

1.47 While there is a small group of wejl-trained and able government officials, the majority of Afghaniftan's civil servants are underqualified for the rasks of development administration. Civ1l servants are paid scarcely enough to make ends meet and despite the rigid control system, petty corruption is rife. There is little capacity to prepare or for that matter to implement projects and heavy reliance is still placed on the three to five thousand foreign technical assistance personnel in the country. As in most countries there is a great deal of talk about upgrading the administration and changing the administrative system. Again, as in most countries, the forces which keep the status quo in its place have proven overwhelming. In many other countries however, this is far more marginal to the capacity tc develop. In Afghanistan because of the development strategy which is being pursued, the weakness of the public administration is the major determinant of the pace at which development can take place. 


\section{THE JOURNEY SO FAR}

\section{A. Afghanistan's Political Evolution 1/}

2.01 Much of the past is the story of invasions. The deserts of the southwest and the mountaln passes of the northeast commanded the rich plains of the Indus and the Ganges. Successively the Greeks, Mongols, Moghuls and Perstans dominated much of the area of present day Afghanistan. A convenient starting point in the story is the movements of Aryan peoples some 3,000 to 4,000 years ago from central and western Asia onto the Iranian plateau and into the India sub-continent. The people and languages of modern day Afghanistan are largely descended from these groups.

2.02 The Aryans established a major center at Balkh in the north. The area around Balkh, known as Bactria, was incorporated into the empire of Cyrus the Great in the sixth century B.C. It was the birthplace of Zoroaster. In 331 B.C. Alexander conquered and occupied the area. The lands to the north and west of the Hindu Kush were ruled by Greek-descended governors till about 50 B.C. The southern and eastern areas however were conquered by the Mauryas, the Buddhist rulers of much of India. The result was a curious fusion of the two cultures which produced among other things, the astonishing GraecoBuddhist figures of the Bamian valley. In the middle of the first century B.C, a nomadic Aryan tribe from Central Asia, the Kushans invaded Afghanistan and established an emptre including much of northern India. One of its capitals was the city of Kapisa (near Kabul). From the fifth to the seventh centuries A.D. control passed into the hands of the Sassanid dynasty which dominated Iran.

2.03 The next two centuries were notable for the successful attempts of Arab invaders to establish Islam. There was also a gradual movement of Iurkic tribes into the area. In the middle of the tenth century A.D., Alptagin, a former Iurkish slave, gained control of the principality of Ghazni in the south and founded the Ghaznevid dynasty, the first great Islamic empire in Afghanistan. It was in this period that the term Afghans came into use to describe the Pashtun tribes of the eastern mountains. At its peak under Mahmud of Ghazni, the empire reached to the Ganges. Ghazni became a renowned seat of learning with a lasting influence on Persian culture. In 1152, Ghazni fell to the rulers of neighboring Ghor in the southwest. The Ghorid dynasty strecched - ts control to northern India and established its base in Delhi.

2.04 In 1220 the Mongols under Genghis Khan invaded Afghanistan, destroying the cities and fortresses in their path. Balkh was burned to the ground and its inhabitants massacred, and many other cities suffered a similar fate. In the middle of the fourteenth century, Timur (Tamerlane) the son of a Turkish tribal chieftain, claiming descent from Genghis Khan created an empire

1/ This section is based on two major sources: (1) Louis Dupree; Afghanistan, Princeton: Princeton University Press, 1973 (2) Harvey Smith, et al: Area Handbook for Afghanistan, Washington, D.C 1973. 
which again reached in:0 Indla. During the preceding period the Pashtun cribes had established themselves in the mountainous areas of the Sulaiman range. Since they controlled the passes which provided access to the Indian sub-continent, there was constant conflict between the Pashtums and the Central Asian invaders.

2.05 In 1504, Babur, a descendant of Timur, laid claim to the emp1re. In the battle of Panipat near Delht in 1526, he broke the power of the Afghandescended Lodi dynasty and established the rule of the Moghuls. Babur loved Kabul and wrote tenderly of its beauty. Although he died in India, he was buried in Kabul as he had requested. For the two centuries following Babur's death, Afghanistan was fought over by the Safavids in Iran and the Moghuls in India. The Pashtun tribes, the Abdalis and Ghilzais were increasing in numbers, and influence during this period. The Moghul rulers maintatned control by using what was to become a favorite tactic, playirg off the tribes against each other. The Ghilzais dominated the area round Kandahar while the Abdalis ruled in Herat and the interior. Nadir Shat the ruler of Iran, used Abdali troops to break the power of the Ghilzai, and on his raids into India.

2.06 In 1747, with the assassination of Nadir Shah by officers of his troops in Iran, Ahmad Khan Sadozal of the Abdali tribe, who had risen to a aigh position in Nadir Shah's army, marched to Kandahar with a contingent of troops. Be made Kandahar his capital and took the title Dur-i-Duran (Pearl of Pearls); since then the Abdali have been called Durani and the ruler took the name of Ahmed Shah Durani. The Pashtuns remained a group of scattered tribes, united mainly by language. Nevertheless the ascendancy of the Durani Pashtuns was a prime factor in the evolution of a national state.

2.07 The beginning of the 19th century saw the first interest of European powers in Afghanistan. The East India Company concluded the Anglo-Afghan Ireaty with the Amir in 1809. At the same time the Russians were keenly Interested in the area. The Afghan rulers, learning perhaps frow their ow past, began a strategy which has been maintained almost to the present day, if exploiting the rivalries of the major powers with interests in the region, :0 their own advantage. Dost Mohammad who had ascended the throne in Kabul 1n 1826, first asked the Russians for support to regain Peshawar from its Sikh rulers, and then turned to the British to help defend Herat against the thah of Iran. The British, distrustful of the Afghan ruler and the Russian -ntentions, launched the First Anglo-Afghan War (1838-42). The British installed a new ruler, but tribal hatred of the British occupation led to a ebellion and the almost complete massacre of the British expeditionary force .n 1842 .

?.08 Dost Mohammad was restored to the throne in 1842. He was gradually ible to regain some of the lands which had been lost in the preceding period. At the end of the Crimean War (1855), Britain and Russia signed a treaty which recognized the independence of both Iran and Afghanistan. This was a period if intense diplomatic activity and delicate manoeuvring betweer. Britain and iussia. The rivaly between the two powers was probably instrumental in keeping 
Afghanistan independent. It was extremely difficult for the Afghan rulers to maintain the necessary balance in their relationships however, and whenever a significant ' $t$ ilt' developed, trouble ensued, A wave of interventionist sentiment in Britain led to Sher Al1 (1863-79) seeking assistance from Russia. The result was a new British occupation following the second Anglo-Afghan War (1878-9). The British elected to withdraw in 1879, but forced Afghanistan to sign the Treaty of Gandamak in that year, which declared that the new Amir was bound to follow British advice in all his relations with other powers. In effect Afghanistan became a British protectorate serving as a buffer between Russia and India.

2.09 The inevitable response came in 1885 when the Russians invaded Afghan territory within a hundred miles of Herat. War was close but a compromise was reached on the boundary and by treaties of 1887 and 1895, the northern boundary was defined and has been maintained to the present day. In 1893 Sir Mortimer Durand pressured the Amir Abdur Rahman (1880-1901) to sign an agreement fixing the border of Afghanistan along a 1,200 mile line which cut the traditional tribal lands of the Pashtuns in half. The Durand line remains to this day an important issue in the relationship between Afghanistan and Pakistan.

2.10 The roots of modern Afghanistan lie in the reign of Abdur Rahman. He set about reducing the independent power of the tribal chiefs and religious leaders, by transferring most of their military and administrative functions to the centril government. He developed a standing army and policy and issued a large number of new laws. His son, Habibullah who succeeded him in 1901 continued his policies. Habibullah introduced European medicine, surgery, automobiles, telephones and telegraph and even opened a school organized on European lines. There was increasing nationalism and anti-British sentiment during this period, as Britain still dominated Afghanistan's external relations. The intellectual communty pressed for closer relations with the Ottoman sultan in Turkey. During the lst World War, Habibullah took the unpopular position of neutrality rather than aligning himself against the Bricish. There was deep popular resentment and Habibullah was assassinated in 1919 .

2.11 He was succeeded by one of his younger sons, Amanullah (1919-29). Amanullah was nationalistic and anti-British. Above all however, he dreamed of emulating Ataturk, and he was passionately interested in social and economic reform. In May 1919, Amanullah attacked the British forces in the third Anglo-Afghan War. Although he was not victorious, the war-weary British decidea to give the Afghans freedom of action in fore1gn relations and recognized their complete independence for the first time through the Treaty of Rawalpindi in August 1919. Amanullah took a trip through Europe, Turkey and Iran in 1928 and returned convinced of the need for sweeping reforms. On his return he outlawed the veil and polygamy and decreed compulsory education for both sexes. He established the first parliament and ordered all Afghans to wear European dress in Kabul. These measures called forth a violent reaction. An 1lliterate Tajik bandit Bacha-i-Saqqo ied an army to Kabul and forced Amanullah to flee to Kandahar, from where he later abdicated and went into exile in 1925. 
2.12 For a few months all was chaos. Nadir Khan, a general of the army, who was living in extle in France and was a descendant of Dost Mohammad, recurned to Kabul and was able to unite the Pashtun tribes and establish himself on the throne. He set about reversing many of Amanullah's sweeping changes. He restored the process of consultation with tribal chiefs and proclaimed the supremacy of the Hanafi School of Islamic Law. He repealed many of the laws and constitutional reforms of his predecessor. However, he did try to extend some of the more positive features of Amanullah's reforms. He planned new hospitals and clinfcs and brought in foreign advisers. Nadir Shah's reign proved to be short and he was assassinated in 1933, to be succeeded by his 19-year old son, Mohammad Zahir Shah, who was to occupy the throne for 40 years.

2.13 The second World War (Afghanistan was again neutral) and the partition of India brought the issue of the Durand line to the forefront. The 'Prontier Ghandf', Khan Abdul Gaffar Khan had campaigned for an independent Pashtunistan which was gradually interpreted not as simply the unification of the Pashtun tribal lands, but the incorporation of those lands east and south of the Durand Ifne into Afghanistan. After the War, econouilc development was also pursued somewhat more vigorously and in 1953 Mohammad Daoud, a cousin of the Shah became Prime Minister. Much of the impetus for economic development through large foreign-aided projects (the second phase of the Helmand valley development, the Nangarhar project, Kandahar airport, the highways and the Salang Pass) were inftiated under Prime Minister Daoud's stewardship which lasted till 1963.

2.14 Afghanistan received relatively large amounts of foreign assistance during the $60 \mathrm{~s}$ and there can be little doubt that this was in part motivated by the cold war rivalries between the USA and the USSR, the two major donors. The rivalry extended even to technical assistance and for much of the period both coumtries had teams in the Planning Ministry. Inevitably in these circumstances, the selection of projects often bore little relation to their economic viability. A World Bank mission which visited Afghanistan in 1971 observed that "ald donors have not been as helpful as they milght have been in assisting a weak and inexperienced administration to become strong enough to take an effective part in development. Some projects have been dictated as much by strategic or ideological considerations as economic ones, and most projects have needed heavy ongoing commltments of finance and manpower both for capital and current expenditures to realize even their modest returns. Donors have insisted on pursuing these expenditures to the exclusion of other necessary activities." 1 /

2.15 The late $60 \mathrm{~s}$ and early $70 \mathrm{~s}$ were years of increasing frustration and disillusionment as the forward momentum of the large infrastructure projects was not malntained and the expected benefits falled to materialize. Many of the more highly educated Afghans left the country, and the Government seemed Impotent to make the changes and reforms whlch vere generally agreed to be essential. The constitution of 1964 had passed a good deal of power to

1/ Report NO. SA-29a: Current Economic Position and Prospects of Afghanistan. Feb. 1, 1972, Volume I, p.1. 
the ministers and parliament. The parliament, however, appeared to follow ths time honored Afghan tradition of decision by consensus. As a result every parliamentarian said his piece on every 1ssue which arose. The main product of the parliament was endless speeches and almost no decisions. The King could have intervened legally but seemed reluctant to do so. Even such a relatively non-controversial issue as the bill to establish an Industrial Development Bank took five years of procrastination and debate before $1 t$ was approved. In $1969 / 70$ for example, the only bill passed by the parliament was the acceptance of an interest free loan.

2.16 Among the provisions of the 1964 constitution was one which barred relatives of the King from involvement in politics. This effectively limited the role which the former Prime Minister Daoud could play in the country's political life. Dissatisfaction continued in the early 70 s, fanned by the droughts of $1970 / 71$ and $1971 / 72$ and the rising food prices which resulted. On July 17, 1973, while the King was visiting Italy, Daoud, supported by a group of army officers seized power and declared Afghanistan a Republic with himself as President. In an address to the nation in August 1973, the President committed himself to the economic development of Afghanistan and to basic social and economic reforms. Inevitably the initial period was concentrated on the achievement of political stability. There were three attempted coups, and as in many other developing countries, the achievement of political stability has been associated with strict control of the press and the suppression of public dissent. By early 1977 however, the regime appeared to be firmly entrenched and a new constitution was incroduced which allowed for the creation once again of a parliament.

2.17 President Daoud has taken a number of important initiatives. There has recently been a rapprochement with Pakistan which offers a great deal of promise for strengthening economlc links with the sub-continent. Desplte occasional strains, Afghanistau has maintained good relationships with its other neighbors, Iran and the USSR and has received substantial ald commitments from those countries. Happliy both the Government and donors seem to have realized that the way aid was approached in the 60 s was counter-productive. All in all there 1 s some ground for optimist that the political basis for sound economic development will be lafd, both domestically and on the international scene.

\section{B. Economic and Sacial Development}

2.18 A visitor to Afghanistan in 1930 would have found an extremely conservative Islamic society, almost entirely rural except for a few small market towns. The largest of these, Kabul, had no paved roads and few modern buildings. It is indeed hard to characterize Afghanistan as an economic unit at that point in time. The journeys from Kabul to Herat and Mazar-1-Sharif took three to four days during the few months of the year that the roads were passable. The main trade was between the nomadic tribes and settled agriculturalists; the nomads provided meat, dalry products and farm labor, in exchange for grain, fruit and vegetables. The main 1 tems of rural consumption which could not be procured locally - tea, sugar, salt and cloth - were bought 
either from the nomads or in the small stores of the market towns. In exchange farmers sold produce or handicrafts such as carpets or sheepskin coats, which had already found a market in Europe and India. There were no banks in the country, money was little used and indeed the rupee was the currency until replaced by the afghant by Amanullah in 1925. A handful of small-scale industries comprised the 'modern' sector.

2.19 To modernize the economy, Nadir Shah turned to two prominent Afghan traders. The first was Abdul Aziz Londoni who had almost singlehandedly developed the export of karakul, and the second, his partner Abdul Majid Zabul1 who was primarily exporting wool to Russia. Zabuli founded the first $b a n k$, later known as the Bank-1-Melli in 1934. The bank was important not only for the investments it made, but also because of the system under which it was established, which became a prototype for much subsequent development. The Government granted the enterprise a monopoly (called a sherkat) and also took a minority stockholding position in the enterprise. The controlling interest was held by the private sector, many of whom were members of the royal family. On Zabuli's urging, the Bank-i-Mel11 1nvested in cotton ginning in the northern swamplands of Kunduz. The settlement of the Kunduz plain, the draining of the malarlal swamps and the establishment of the Kunduz cotton company can justifiably be called Afghanistan's first major development project.

2.20 After Nadir Shah's violent death in 1933 the new King's uncles, who were the effective rulers for the next twenty years, continued the efforts at modernization. Most importantly there was a notable opening up to outside influence. It was felt better to stay clear of the Russians and the British (writers of the time characterized Afghanistan as a goat between those two 1ions), and instead the Government turned to Germany, Italy and Japan. The Germans became the most influential group and carried out some important research. Companies from all three countries set up offices in Kabul and a fairly regular weekly air service between Berlin and Kabul was established in 1937. The second World War brought a halt to economic progress though it did provide good markets for whatever Afghanistan could sell, so that by 1945 considerable foreign exchange reserves had been accumulated.

2.21 The progress from 1930 to the war's end had been mainly in the establishment of a small, but powerful privace sector and in the creation of a limited number of supporting institutions. A central bank, the Da Afghanistan Dank had been added to these in 1938. Trade had expanded and, perhaps most significantly, the high schools, which had been opened in Amanullah's time and were often staffed by foreigners, had begun to turn out a group of students who were subsequently able to take the lead 1n administration. A faculty of medicine had been founded in 1932, but Kabul University was only established 1n 1946. In relation to the country as a whole, however, the advances were modest indeed. The seeds of change, which Amanullah had planted without adequately preparing the ground, had not yet taken root. The countryside remained untouched by schools other than those of the mullah, health care except for traditional medicines, transport facilities, electricity, clean water and sewerage facilities. 
2.22 The end of the war found the Afghan Government flush with foreign exchange and ready to take up the project that had long been a dream - to irr. gate the southwestern desert through the waters of the Helmand river. The Helmand Valley Project began (there were however some earlier projects in the valley with German and Japanese assistance) as a direct association between th Government and the American firm of Morrison-Knudsen(M-K). The Helmand Valley Profect was the beginning of a saga which continues to the present. "Human problems at all levels, from peasant resistance to bureaucratic folderol, bese the Helmand Valley project from its conception. Neither the Afghan Government nor the American engineering company understood the monumental problems of enfolding an entire region in the embrace of a single project. The Helmand watershed drains forty percent of Afghanistan's land area." 1 / The approach to 1rrigation development was back-to-front. First the dams were built then attention was glven to the preparation of the land to be frrigated, then to testing the solls, and finally to teaching the settlers how to irrigate.

\subsection{In 1945 costs had been estimated at $\$ 63.7$ million, but they soon} mushroomed far beyond that level. The forelgn exchange surplus dwindled and the US Export-Import Bank was approached for a loan of $\$ 21$ mill1on for the project which was given in 1949. M-K actually completed the construction of the two dams and the Boghra canal system ahead of schedule, but in order to do so, short-cuts were taken and smaller projects and surveys were not undertaken. This was to plague the project later. In 1952, the Government created the Helmand Valley Authority (HVA) with its president given cabinet status. The main dam at kajakal ( 300 feet high, 887 feet wide, 32 mile reservoir and $1,495,000$ acre-feet capactty) was inaugurated in Apr11 1953. This was only the beginning of the saga. In June 1953 Ex-imbank gave a further $\$ 18.5$ million loan and an agreement was signed with an official US aid agency for the first: time (TCA at that time). The money was for drains, power and land development in the valley.

\subsection{By 1955 the Government had spent $\$ 70$ udlion of Afghan1stan's scarce} reserves on the Helmand Project. Ten years later the return on the project were abysmal in terms of increased production, and it was being legitimately asked what had gone wrong? First was the fallure to identify and implement drainage needs. There was serious waterlogging and salinity in many cases which reduced yields substantially below those of the initial years. In the worst case, waterlogging and salinity resulted in malaria and the departure of the settlers. The second major problem lay in the settlement part of the project. Newly irrigated land was given to nomads of different etnnic groups, without adequate preparation and buildup of supporting services. Thirdiy, Afghanistan's civil service was not really prepared for a project of this complexity and magnitude. Maintenance was inadequate, and bureaucratic procedures resulted in endless wasting of time and money. The project was to prove a tremendous leaining experience, but a rather costly one. "Too many decisions

1/ Dupree, op. cit. p. 483. 
vent unmade, too many farmers unsettled, so the desert did not bloom and the bread basket remained relatively empty." $1 /$

\subsection{5}

In other respects however, the decade from 1953 to 1963 under Prime Hinister Daoud, was the most dynamic that Afghanistan's economy had experienced. The centerpiece of the new approach to the economy was the shift from the old coalition of the private sector and the royal family through the mechanism of the sherkat, to a state planned and guided economic development. The period was also characterized by a shift towards the USSR and large amounts of a1d from that source, beginning in 1954 with loans for the construction of silos in Kabul and Pul-1-Kumri and the paving of streets in Kabul. The Governmen's primary interest however, was in infrastructure. The difficulties with Pakistan over the Pashtunistan issue had re-awakened fears over the vulnerability of Afghanistan's external trade access, and the main feature of the agreement with the USSR for $\$ 134$ million of assistance signed in 1956, was the construction of a highway from Kabul to Sherkhan Bandar on the Amu Darya River, including the three kilometer long Salang Tunnel.

\subsection{In March 1956 the First Five-Year Plan was launched, based largely} on recommendations of Soviet advisers. The Soviet involvement in planning and ald touched off a lengthy period of competing assistance from the US which responded with $\$ 92$ million of ald. This had an unfortunate beginning with the rovision of $\$ 15$ million for the construction of the Kandahar International Airport which has dchieved notoriety as one of the classic 'white elephants' of international assistance. The US effort was concentrated in road links with Pakistan and in the Helmand. The first Plan allocated over 30 percent to agriculture and irrigation, with 25 percent in transport and communications. In practice, however, expenditure on the Plan did not accord with the allocations and transport investment, which was carried out essentially in turnkey fashion and was therefore less dependent on domestic project implementation capactit, accounted for 50 percent, while only 13 percent was spent on agriculture despite the Helmand. It is perhaps a recurring theme in Afghan planning, but was particularly marked at the outset, that the Plan was governed mainly by the type of assistance foreign nations were willing to provide. There was no attempt to integrate or coordinate projects and sectors.

2.27 Prime Minister Daoud resigned in 1963 to promote the liberalization of the political system. This also permitted an improvement in relations with Pakistan as he had become 1dentified with confrontation over the Pashtunistan issue. By then the foundation existed for sweeping changes in Afghanistan's

I/ Dupree, op. c1t., p. 507. 1977 takes a somewhat kinder view of the Helmand than the late sixties, however. Not only has production increased significantly, but many of Afghanistan's better agricultural personnel recelved invaluable training and experience on the project. It is arguable that no matter where 1 was located, or how well it was planned, Afghanistan's first major irrigation project was bound to be a "Helmand", See also para. 4.21. 
economy; paved roads, increased power supply, new state-run and omed companie producing metal products, textlles and cement, etc. But perhaps even more importantly by 1963 the concept - a revolutionary one in Afghanistan - that the Government was responsible for the economic development of the country, was broadly accepted, at least among the educated and in the urban areas. In the rural areas the 1 dea of change was still remote, wut even there the roads were causing changes in attitudes and life-styles.

2.28 The Second Plan $(1962-67)$ envisaged a fourfold increase in expenditures over the first and even though this proved unattainable, total Plan expenditure was still more than double the previous Plan. The emphasis on infrastructure projects particularly in the highway sector was continued, since there were a large number of ongoing profects. By the end of the Plan Afghanistan had 1,200 miles of paved roads which linked all the major regions of Afghanistan with Russian and Paklstani rallhesds. Most major cowns were within a day's travel of the capital. Power output during the period had expanded at the rate of 25 percent a year due to the completion of a number of hydro-electric projects near Kabul by the USSR and Germany. The total number of schoolgoers rose in the two Plans from 126,000 to 540,000 , and by the end of the Second Plan there were 5,000 students at Kabul University.

2.29 The vast expansion in infrastructure facllities and trained manpower did not however reflect itself fully in increased production and income, although the new industrial units constructed during the two Plans did of course result in new output. Soviet technlcians discovered deposits of natural gas, and production began in 1967. Coal production increased from 17,000 tons in 1954 to 147,000 tons in 1966. Cement production commenced in 1958 and reached 158,000 tons by 1966. There were, however, a total of only 20,000 employees in the 59 industrial establishments wth more than 20 people in Afghanistan in 1966. Over 12,000 of these were in textiles. All in all this represented a rather modest role for the "modern' sector, probably less than 0.5 percent of the labor force and less than 3 percent of NDP.

2.30 The data on agricultural production are not sufficiently reliable to interpret what was happening during the period. But given the sluggish progress of the major irrigation projects, particularly the Helmand and the Russian aided Nangarhar project, and the limited use of modern inputs, there is no reason to believe that it had grown any faster than population. The most notable increase was in frut production. This was based largely on the expansion of acreage under fruits due to favorable prices. Some of this expansion was at the expense of wheat, but the total amount of land under orchards was still only 2 percent of total cultivated land by 1967 . The failure to expand cotton and sugar production was particularly disappointing and appears to have resulted in large part from the unfavorable prices offered to producers.

2.31 During the period of the first two Plans, Afghanistan, unlike many other developing countries, was not constrained by a shortage of financial resources. For example the World Bank, despite considerable availability of funds and staff input was able to finance but a single project by 1967 - a loan for education of $\$ 3.5$ million which was never disbursed, and was later 
cancelled at the Government's request. The constraints lay in the identification and preparation of projects, the ability to take timely decisions and the capacity to implement wh thout unreasonable amouts of foreign technical assistance. Over the two decades 1950-1970, a1d to Afghanistan averaged about $\$ 65$ milion a year, much of $1 \mathrm{t}$ in the form of commodity assistance. About 50 percent came from the USSR and 30 percent from the USA. The level of aid per capita of about $\$ 5$ per annum was near the average of all developing countries during this period.

2.32 The Third Pive-Year Plan (1967-71) proposed to reduce the emphas1s on Infrastructure projects in favor of smaller, quicker yielding projects in agriculture and industry. In the circumstances these good intentions were not realized. Delays in the ongoing large projects made the redirection of resjurces almost 1mpossible both because they pre-empted scarce local manpower and because forelgn donors were locth to begin new projects while difficulties persisted with existing ones. Well over half of the eventual Plan expenditure was devoted to carryover projects. The 1 mplementation of the Plan was also severely affected by the droughts of 1970 and 1971 which caused a decline in wheat production by an estimated 20 percent below normal with simlar declines in other crops. Livestock production also contracted. The numbers of sheep fell by more than 40 percent. The Government moved wth surprising effectiveness to distribute imported foodgrains and widespread starvation was averted. Even so the nomads and some of the more isolated villages suffered severely from lack of food. Triggered by the droughts, the early 70 s were characterlzed by increasing restlessness with the lackluster economic performance and the ineffectual quality of the leadership. There was little sense of forward momentum as had been the case ten years earlier. A fourth Plan covering the period 1972-77 was drawn up, but not 1mplemented due to the change in Government in 1973.

2.33 The World Bank report of 1972 // summed up the situation as follows: "The past fifteen years have been frustrating and disappointing for those concerner with development in Afghanistan. A relatively large volume of aid sustained high levels of investment to little visible purpose in terms of higher standards of living for the vast majority of the population. To some extent it was inevitable that the major share of this investment would be needed for basic economic and social infrastructure, with long gestation periods. However it has proved difficult to move from this stage to a point where effective use can be made of the infrastructure created, and a proper impetus can be provided to the kind of productive activities which result in widespread increases in in come."

2.34 The report continues "The responsibility for this situation lies primarily with the inadequacies of the administrative structure. This is reflected in the failure of the government to manage the large number of public enterprises efficiently, to allocate funds within projects so as to secure the maximum return, to gear up its administrative capacity to prepare new

1) SA-29a, op. ctt., p. 1 . 
projects, to 1 mplement projects efficiently through the cperating ministries, and to promote the institutional and legislative changes needed to create an appropriate environment for private agricultural and industrial development." Nor did forelgn donors escape these strictures. Their role had often adversely affected allocation and the development of domestic capacity. The report urged on the Government a period of consolidation "which would allow a reallocation of investments to emphasize the utilization of existing capacities rather than the creation of new ones."

\section{The Economy from 1973 to 1977}

2.35 The coup of July 1973 is testimony to the failure of the period which precelded it. There was a general consensus that the development effort had slowed down. This was not only a matter of the disastrous droughts of $1970 / 71$ and $1971 / 72$ but, more seriously, the fallure of the institutional base to evolve. Critical decisions were being held up by the tortuous procedures of the Jirgeh (the parliament), the administration was weak and dispirited. Donors were weary of sluggish project implementation and the failure to utilize the substantial infrastructure which had been created, so that aid inflows were considerably below their earlier levels. In the years following the coup, the consolidation suggested in the Bank's 1972 report has indeed begun: much of the effort has been directed at institution building leading to the preparation of the First Seven-Year Plan in 1976 and the issuance of a new constitution in 1977.

2.36 An important element in this consolidation phase was the series of good harvests and ample rainfall from 1972/73 to $1975 / 76$. These encouraged the spread of inputs such as 1 mproved seeds and fertilizer, and enabled the flocks and herds, which had been decimated by the earlier droughts, to recover gradually. Among the most striking changes in the period was the diversification of agricultural output with the increasing production of cotton, sugar and other commercial crops on irrigated land. This was possible because good harvests of dry land wheat meant that Afghanistan was self-sufficient in the food staple, and kept 1ts price at reasonable levels. The poor harvest of 1977 has somewhat reversed this trend, and sizeable imports of wheat (about. 200,000 tons, equal to about 6.6 percent of total supply) are needed. Table 3 below gives an indication of the progress of agricultural production in the period. 
Table 3: AGRICULTURAL PRODUCTION INDEX

$(1968 / 69$ is equal to 100$)$

$\begin{array}{llllll}1971 / 2 & 1972 / 3 & 1973 / 4 & 1974 / 5 & 1975 / 6 & 1976 / 7\end{array}$

\begin{tabular}{lrrrrrr} 
Wheat & 81 & 104 & 115 & 117 & 121 & 125 \\
Corn & 87 & 93 & 98 & 100 & 101 & 104 \\
Rice & 87 & 100 & 104 & 104 & 108 & 111 \\
Barley & 98 & 97 & 100 & 105 & 106 & 110 \\
Cotton & 89 & 82 & 152 & 204 & 225 & 224 \\
Sugar Beets & 97 & 102 & 103 & 108 & 162 & 147 \\
Vegetables & 111 & 101 & 104 & 107 & 110 & 140 \\
Fruits & 78 & 96 & 101 & 104 & 106 & 108 \\
\hline
\end{tabular}

Source: Central Statistics Office.

2.37 On returning to power, President Daoud enunciated a policy emphasizing the role of the state particularly in developing heavy industries based on minerals and other resources. To promote this pollcy, the banks were nationalized. As a consequence of nationalizing Bank-1-Melli the Government gained control of the sherkats, by far the most importaut private firms, which had been established through that organization. These statements and measures caused a crisis of confldence in the privare sector. Private investment slowed to a trickle. Prior to the coup, thera had been considerable response to the Foreign and Domestic Private Investment Lav, with its I1beral incentives for private industry. After the coup most of the pending applications were withdrawn or if approved, were not implemented.

2.38 The Government took steps towards better ut1lization of the substantial capacity in the public sector - and with some success, as shown by the higher output after 1973 in Table 4 below.

Table 4: INDUSTRIAL PRODUCTION INDEX

$(1968 / 69$ is equal to 100$)$

\begin{tabular}{|c|c|c|c|c|c|c|}
\hline & $1971 / 2$ & $1972 / 3$ & $1973 / 4$ & $1974 / 5$ & $1975 / 6$ & $\begin{array}{c}\text { Est. } \\
1976 / 7 \\
\end{array}$ \\
\hline Coal & 108 & 57 & 93 & 92 & 120 & 128 \\
\hline Natural Gas & 150 & . 171 & 165 & 174 & 178 & 157 \\
\hline Sugar & 160 & 134 & 140 & 168 & 257 & 209 \\
\hline Vegetable 011 & 129 & 126 & 184 & 274 & 342 & 326 \\
\hline Ginned Cotton & 124 & 113 & 185 & 242 & 327 & 390 \\
\hline Cotton Textiles & 126 & 125 & 126 & 140 & 124 & 151 \\
\hline Cement & 81 & 100 & 149 & 167 & 163 & 138 \\
\hline
\end{tabular}

Source: Central Statistics office. 
Even after these increases in production however, the share of modern industry in NDP remains little over 3 percent. Hence these figures are more important as indicators of the discipline which the government was able to instill into the enterprises than in terms of their economic impact.

2.39 A far more important economic indicator was exports and foreign exchange earnings during the period. During the drought years Afghanistan's exchange rate depreciated rapidly as fmports were high, export availabillties were reduced and above all food moved, often 111 legally, across borders to meet the country's defic1t. The situation was reversed with the good harvest in 1973 and the exchange rate appreciated from 91 Afghanis to the dollar in April 1971 to 70 to the dollar by Apri1 1973. The measures taken by the government included tighter control of fmports and higher production in export industries. This was given a boost by the acceleration in the prices of many of Af ghanistan's exports in the period from 1972 on. The result was that the exchange rate continued to appreclate reaching Af 60 to the dollar in April 1974, Af 55 to the dollar in April 1975 and Af 42 to the dollar in October 1976. This appreciation threatened to make many of the traditional exports unprofitable, and the government intervened to bring the rate up slightly to 47.5 afghanis to the dollar by April 1977. 1/ In the meantime the level of reserves rose from $\$ 56$ milion in March $197 \overline{3}$ to $\$ 215$ million by March 1977.

2.40 There are many reasons for this trend. First, although the evidence suggests only a modest improvement in the country's terms of trade, much of the increase in incomes from exports went into the hands of agriculturalists such as cotton and raisin growers. These groups have relatively low consumption elasticities, and extremely low 1 mort consumption elasticities, with the result that demand for imports did not rise proportionately either from the direct or indirect impact of export earnings. Secondly, there were earnings from remittances from Iran by a large groups of Afghan workers who migrated there after the oll price increase. Estimates of the size of this group range from 100,000 to 300,000 . Thirdly, according to narcotics control agencies, following the reduction in the supply of Vietnamese narcotics on the world market after 1973, it has been suggested that there has been an increase in supplies from Pakistan and Afghanistan. This claim is however disputed by the Government. Fourthly, during the period of increasing instability in Pakistan, Afghanistan may have been the route for a good deal of capital flight from that country. These factors, plus the good harvests and sizeable offers of foreign aid from Iran and other OPEC countries after 1973, have contributed to the strength of Afghanistan's external position. Many of these factors are volatile however, and substantial fluctuations in exchange earnings and therefore exchange rates are possible in the medium-term.

2.41 There was also some improvement on the domestic resource front. The Government embarked on a vigorous program of tax collection, and revenues increased at the extraordinary rate of 18 percent a year in real terms from

1/ Upward pressure subsequently resumed however and by end December 1977 the rate had returned to Af 43 to the dollar. 
1973 to 1977. As a result the Government repaid much of its earlier borrowings from the banking system. It has been argued, however, that the tax collection was indeed too vigorous and frequently relied on arbitrary assessments by individual officials, a factor further contributing to the general disillusionment of the private sector. In 1976 the Government introduced a graduated land tax to remedy the relative under taxation of the agricultural sector (1.e. through direct taxation, but 1gnoring the para-tax effect of controlled agricultural prices). The graduated land tax is linked to the land reform which the Government is attempting to introduce, in that payment of the tax is necessary to establish the legal ownership of the land. Collections thus far have fallen considerably short of the amounts budgeted.

2.42 The factors mentioned above have resulted in relatively modest price Increases (averaging about 6 percent per annum from 1973 to 1977). This has occurred despite a doubling of the money supply over the same period. Part of the reason for this would seem to be that growth and monetization absoribed much of the annual increase in the money supply. In addition, it would appear that much of the increase in income went into the hands of agriculturalists and has been hoarded. There is little awareness in rural Afghanistan of the concept of inflation and the eroding purchasing power of money. On the other hand a great deal of weight is attached to liquidity. Despite positive rates of interest, bank deposits are almost unheard of outside the urban areas. Finally the rapid appreciation in the foreign value of the afghanl may have resulted in substantial speculative demand for the currency both at home and abroad.

2.43 'Consolidation' is as good a word as any to describe the period from 1973 to 1977 . Income rose rapidly from the depressed base of 1971 and 1972 , but when measured over a longer period, using a base of $1968 / 69$ for example, it probably did no more than keep pace with the rate of increase in population. The real achievements of the period are perhaps more in the return of stability by 1977, and the steady growth of a number of key institutions, particularly those serving the agriculture sector. It is against this background that the First Seven-Year Plan has been prepared.

\section{The F1rst Seven-Year Plan}

2.44 Planning in Afghanistan is an menviable task. The data base $1 \mathrm{~s}$ at best weak and at worst nonexistent. There is no broad consensus on development objectives to guide the planners. There 1 s a shortage of technical manpower to identify and prepare projects. In these circunstances the "First Seven-Year Economic and Social Development Plan 1355-1361 (March 76-March 83)" is a bold and often impressive attempt to understand Afghanistan's problems and to evolve a strategy for dealing with them. There is much to criticize about the Plan, but it has the overriding virtue of providing a focal point for thought and debate about the direction which development should take.

2.45 As discussed in Section C above, there is a considerable history of planning in Afghanistan. The four Five-Year Plans beginning in 1956/57 were predominantly the work of fore1gn advisers and reflected a development effort which consisted largely of projects selected, prepared, 1 mplemerted and financed 
by foreign donors. These projects were frequently poorly formulated; in part because of the foreign advisers' 1gnorance of the Afghan environment. In some ways the present Seven-Year Plan still reflects many of these earlier weaknesses. The Plan presents a large number of projects. Many of these have been subject to only the most cursory technical and economic analysis. In addition, many of the project schedules are unrealistic in their assumptions concerning the 1mplementation capacity of the operating ministries.

2.46 Granting these criticisms, however, the Plan is a definite step forward. There was greater local input than ever before. An attempt was made to involve the operating ministries in preparation of the sectoral plans and there was an effort to coordinate the preparation through working groups composed of interested.ministries. The objectives of the Plan are very ambitious, but not perhaps unreasonable as targets. An exception to this is the scale of the investment program, but even here there is a recognition by the officials in charge of planning that a more appropriate estimate of likely achievement would be about 60 percent of the target. While such a large program is understandable as an attempt to veet donor preferences and to accommodate special interest groups wthin the country, 1t compromises one of the major objectives of the Plan - to embody national development priorities. The annual planning process will need to focus on developing a leaner investment program which allows scarce manpower to be concentrated in the areas offering the highest economic return.

2.47 In a chapter entitled "General Pollcy Framework of the Plan" (p. 21) a statement is provided of the priorities of the political leadership. There are 18 separate points and the first begins with the declaration that "The Republican State of Afghanistan attaches great importance to the creation of heavy industries such as mineral extraction, machinery manufacturing units, chemical and power industries etc., which are basically necessary for rapid economic growth and for the ma1ntenance of an independent economy." The first reference to the rural sector is contained in point 7 which relates to land reform. Table 5 below gives an indication of the implicit plan priorities.

Table 5: SECTORAL SHARE IN PLAN OUTPUT AND INVESTMENT

(in percentages)

Growth of value-added annua $11 \mathrm{v}$

Total GDP

Industries, Mines and Energy

Agriculture, Animal Husbandry and

Irr1gation

Transport and Communication)

Social Services
6.2

Share of total

investment in

7 year period

100

9.4

37

4. 6

25

7.2 
2.48 Perhaps the most striking feature of Table 5 lies in the very large allocation for transport ( 32 percent). This compares with a 15 percent allocation of total investment in the seven years preceding the Plan, and recalls the late 50 s and early 60 s when the construction of the highway to the north from Kabul, over the Salang Pass, dominated the total Plan expenditure, This large allocation is due to the proposed construction of a rallway line from Islam Qala on the Iranian border to Kabul, with a branch line to the Hajigak iron ore deposits. $\$ 890$ million are proposed for the present Plan period, financed largely by afd from Iran, with a total cost of $\$ 1.2$ billion. (All figures for the Plan period are in 1975/76 prices.) The rallway alone constitutes no less than 23 percent of total Plan expenditure - virtually equal to the entire proposed expenditure on agriculture, animal husbandry and irrigation. The next largest project in the Plan is the $\$ 120$ million to be spent during the Plan period for the initial stage of the copper smelter at Ainak to be built and financed by the USSR.

2.49 Preliminary feasibility studies have been carried out on the development of a railway on a basis which excludes from the evaluation its role in providing an outlet for a proposed $\$ 800$ million project to exploit the 1ron ore deposits at Hajigak. Only a small portion of the expenditure on this project is included in the current Plan. Nevertheless, the railway should be looked at against the background of the overall strategy of developing heavy industry. There is an important school of thought in Afghanistan which has, for many years, viewed Bafigak iron ore as being central to Afghanistan's future development. It derives its source from the views of development which prevalled in many countries fifteen or twenty years ago, which tended to equate development with heavy industry in general and the steel industry in particular. Preliminary studies have indicated that the exploitation of Hajigak would only be feasible on a massive scale, primarily for export. The construction of a rail-link would be a necessary condition for the feasibility of the proposed steel project, although $1 \mathrm{t}$ would also provide an out let for the products of other heavy industries, such as copper, coal and cement. The overall approach has obvious links to the Soviet model of development.

2.50 The experience of the past 15 years suggests that heavy industry is neither a necessary nor a sufficient condition for the economic progress of countries at Afghanistan's stage of development. In fact, various technical studies suggest that Afghanistan's comparative advantage lies more in the processing of agricultural surpluses both for the domestic market and for exports, than in heavy industry. This does not, of course, preclude the possibility that particular projects in areas such as cement production and coal mining may have high economic returns and should be accorded priority in the Plan period.

2.51 The spectfic programs and their financing are discussed in subsequent sections of the report. In the past, Afghanistan's Plan has been regarded as a document delineating a broad range of possibilities rather than a rigid investment program. It is in this spirit that the report has approached the Plan. The sectoral chapters represent an attempt to define those elements in the program which most closely conform to the country's needs and opportunities, within the constraints set by the avallability of manpower and financial resources during the seven-year period. 


\section{THE ROUTE AHEAD: POPULATION AND INCOME}

3.01 The delineation of a development strategy for Afghanistan must begin with a definition of the present standard of living. The figure for GNP per capita is a useful yardstick of progress over time and provides some basis for international comparisons. It must be supplemented however, by an understanding of patterns of income distribution within the country and a knowledge of the extent to which income has been translated into the provision of basic goods and services to the population. Afghanistan must evolve a development strategy which is geared not only to higher growth of per capita GNP, but to insuring that income is fairly distributed and that the primary living needs of the vast majority of the population are met.

\section{A. The Demographic Perspective}

\subsection{The principal objective of the Seven-Year Plan is "to accelerate} economic growth to raise the standard of living of the people." To begin the analysis, let us use GNP per capita as a simple measuring rod for the standard of living. It follows that ralsing living standards entalls increasing the rate of growth of aggregate income and/or lowering the rate of growth of the population. Within the time horizon of the Seven-Year Plan though, the rate of growth of population : unlikely to change much, so maximizing the growth of per capita income boils down to maximizing the growth of output. In the longer run, however, the optimal strategy in a relatively labor abundant, capital scarce country like Afghanistan probably calls for both raising the growth rate of GNP and reducing the growth of population. This is not however to imply independence of means; the maximization of economic growth calls for restrained population growth to allow sufficient investment in directly productive activities, and rapid per captta income growth is in itself a force that can act to slow down population growth.

3.03 The dynamics of population growth are slow yet powerful. There is little that can be done to counter its effects in the current generation, yet it is in this generation that the patterns of population growth in future generations are determined. Here lies the danger, for in a world of sequential fixed term plans with set targets, it is all too easy for population policy to be neglected or assumed away, on $+y$ to have the problem keep reemerging in ever more serious degree. But each time it is once again too late significantly to aifect growth for another generation. It is imperative that population policy look beyond the traditional five to seven year planning period. Failure to do so under any circumstances is an enormous mistake, but in countries where fertility is high, infant mortality high but on the decline, and the population structure extremely young it could negate much of the development effort. Afghanistan is one such country.

\section{(1) Demographic Characteristics}

3.04 The demography of Afghanistan is 1argely unknown. There has never been a national census, and the little census and survey work that has been done is either incomplete, location specific or demonstrably inaccurate. 
3.05 In the view of the World Bank, the best and most recent estimates are beginning to point to a 1977 population of Afghanistan in the 13-15 millon range, with the most likely single estimate about 14 million. Approximately 1.5 millon are belleved to be nomads, of the remaining settled population of 12.5 million, approximately 2 to 2.5 mlllion are classified as urban (as defined by the Government to comprise the 87 mumicipalities), and the remaining 10 to 10.5 million rural. Thus about 85 percent of the total population can be classified as rural. Present population growth is moderate - ISPC estimates suggest growth in the 1.8 percent -2.5 percent range, with the most likely single estimate being about 2.2 percent.

3.06 The analysis of the World Bank suggests that the population of Af ghanistan stands poised to grow at unprecedented rates. Three primary reasons can be identified: $1 /$

(a) The population has a youthful age structure - 16.5 percent are less than age five, and 43.2 percent less than age fifteen.

(b) There is the potential for a rapid decline in mortality. Mortality is extremely high - the crude death rate 1 s estimated at about 30.7 per thousand. Infant mortality is among the very highest in the world. ADS survey results adjusted to compensate for the underreporting of deaths that is prevalent in all surveys of this type, indicate an infant mortality rate of 269.4 per thousand - more than one-fourth of all those born, die before age l. Similarly, the age structure of mortality is overwhelmingly skewed towards the younger ages. This is shown in Table 6.

Table 6: AGE STRUCTURE OF MORTALITY 1972-73

\begin{tabular}{cc} 
Age Group & Percent of all Deaths \\
\cline { 2 - 2 } $0-1$ & 37.9 \\
$1-4$ & 15.5 \\
$5-14$ & 8.2 \\
$15+$ & $\frac{38.4}{00.0}$
\end{tabular}

Source: ADS, 으.c1t., Vol. I, Table III.4, p. 48.

As a consequence of consecutive childbirths, maternal mortality is also very high. Life expectancy at birth is extremely low, but while an important indicator for international comparisons of mortality levels in different countries, 1 toes give a distorted picture of what age Afghans on average can expect to live given the extremely high infant and child mortality in Afghanistan. This is shown in Table 7 .

1) Unless explicitly stated otherwise, all statistics apply to settled population only. Net migration is assumed to be zero. 
Table 7: LIFE EXPECTANCY BY AGE AND SEX - 1975

\section{Males Females}
(a) at b1rth
34.0
36.0
(b) at age 1
46.7
46.9
(c) at age 5
49.5
49.9

Source: Spitler, N. and Frank, N. op.cit.

Estimates employ "East" model Coale-

Deweney liffe tables.

(c) Fertility is extremely high - the crude birth rate is estimated at 51.4 per thousand. The total fertility rate (the average number of live births a woman has during her reproductive life) is about 7.7. The following table shows age-specific fertility rates (number of live births per thousand women per year).

Table 8: AGE-SPECIFIC FERTILITY RATE 1972-73

(per 1,000 women)

Age

$$
\underline{15-19} \quad \underline{20-24}
$$$$
\underline{25-29}
$$

$\underline{30-34}$

$\underline{35-39}$

$\underline{40-44}$

$45-49$

Age Specific

136

313

343

291

236

143

80

Fertility Rate

Source: Spitler, N. and Frank, N. op.cit.

3.07 The significance of the above demographic characteristics can be seen by a comparison with countries of similar geographic and social background.

Table 9: BASIC DEMOGRAPHIC INDICATORS OF SELECTED COUNTRIES - 1973

\begin{tabular}{lcccc} 
Afghanistan & $\begin{array}{c}\text { Cruíe } \\
\text { Birth Rate } \\
\text { (per thousand) }\end{array}$ & $\begin{array}{c}\text { Crude } \\
\text { Death Rate } \\
\text { (per thousand) }\end{array}$ & $\begin{array}{c}\text { Life } \\
\text { Expectancy } \\
\text { at Birth } \\
\text { (both sexes) }\end{array}$ & $\begin{array}{c}\text { Rate of } \\
\text { Natural } \\
\text { Increase }\end{array}$ \\
Sri Lanka & 51.4 & 30.7 & 35.0 & $2.1 \%$ \\
Pakistan & 28.6 & 6.3 & 67.8 & $2.2 \%$ \\
Morocco & 47.4 & 16.5 & 49.8 & $3.1 \%$ \\
Iran & 46.2 & 15.7 & 51.4 & $3.1 \%$ \\
Iraq & 44.8 & 13.7 & 53.5 & $3.1 \%$ \\
Tanzania & 48.1 & 14.6 & 52.7 & $3.4 \%$ \\
& 50.2 & 20.1 & 44.5 & $3.0 \%$ \\
\hline
\end{tabular}

Source: UN Population Division: Selected World Demographic Indicators by Countries, 1950-2000. ESA/p/W p. 55, May 1975. 
to implement a population planaing program, but in the context of Afghanistan, where there is a good deal of complacency about the population question, despite considerable pressure on available land, this perspective is important. And for a country like Afghanistan where so many factors conspire to blemsh the quality of life, there is probably no more potent combination of policies which could be pursued to ameliorate the present and at the same time safeguard the future.

\section{B. A Profile of Living Standards}

3.14 In a poor country like Afghanistan, the standard of 11 ving depends on the extent to which the basic needs of subsistence are met - whether people have sufficient food, clean water, enough clothing, adequate shelter and fuel, the opportunity to receive health care, and a basic education. In Afghanistan these needs are not currently met for the majority of the population.

\section{(1) Nutrition}

3.15 The evidence on the quality of nutrition in Afghanistan 1s somewhat confusing. The aggregate data suggest that there is enough food in most years, and Afghans on the whole appear healthy - one sees little obvious malnutrition and equally little obesity. Fet there is no doubt that poor nutritional practices are a major contributor to health problems, particularly infant and child mortality. Flgures for both population and aggregate food production of Afghanistan are unreliable, making an accurate assessment of per capita food consumption almost impossible. On the basis of the official cereal production estimates and a population of 14.0 million, overall food availabilities would appear to be adequate in good years. Assuming that all wheat and rice (except for spoilage and seed requirements of 10 percent), as well as half the malze and one fourth the barley, is for human consumption, the aggregate per capita cereal consumption is approximately $240 \mathrm{~kg}$ annually. The calorie equivalent of this intake is approximately 2,250 , about 7.5 percent below the FAO estimated dally requirement of 2,440 calories. However, even the poorest families consume some sugar and seasonal fruits and vegetables. Simllarly, the relatively high protein content of the cereals consumed, and the annual average $11.5 \mathrm{~kg}$ of meat and $60 \mathrm{~kg}$ of milk equivalent consumed per capita put Afghanistan well ahead of the minimum proteln requirements (about $22 \mathrm{~kg}$ per person per ann um).

3.16 The majot concerns with food avallability center around 1ts distribution. In the past, during years of shortage, cereals were slow to move to affected regions. The cities were generally the first recipients of 1 mports while the neediest regions, which were often the least accessible were the last. These are usually the regions where dry land wheat is produced. $1 /$

1/ The main dry-wheat growing areas (the provinces of Jowzjan, Badghis, Farfab, and parts of Herat), are mountainous regions not yet connected to the all-weather road system. 
During the disastrous droughes of $1970-72$, such regions did eventually recelve aid, but not before many families had lost their entire wealth. $1 /$ The problem lies in poor communications and transportation facilities, and inadequate administrative procedures.

3.17 Food is far and away the most important item in the family budget In Afghanistan. According to the 1968/69 consumer expenditure survey in the Lashkar Gah area, rural families spent 65.6 percent of their expenditure on food, and urban families 60.7 percent. 2 / Typical daily meals in the household of a laborer or small farmer consist of nan (a wholewheat unleavened bread with a flat irregular oval shape, about a foot long and six inches wide) and tea (no milk, but plenty of sugar), w1th a soup or sauce and perhaps yoghurt at noon and evening meals. Fresh milk is rarely consumed. On special occasions much more elaborate meals will be prepared, consisting of different rice pilaus, meat dishes, and sweets. And depeuding on the season, meals are supplemented by the plentiful fruits and vegetables. In the isolated, mountainous areas that grow no fruits and few vegetables, diets are more monotonous Surveys suggest that the population prefers a varied and healthy diet if they can afford it. A survey carried out in a village in northern Afghanistan indicated a high income elasticity for meat, fruits and vegetables at quite low income levels, and for milk products and eggs at higher incomes. $\underline{3}$ /

3.18 Children are the most vulnerable group to illness and their nutritional status is always of particular concern. The fact that Afgianistan has one of the highest infant and child mortality rates in the world adds to the urgency. Unfortunately, survey data are incomplete and often conflicting; 4 / nevertheless, strong preliminary conclusions can be drawn that point to a medical problem deeply rooted in traditional childbearing practices. An

1/ E1ther they were forced to sell their flocks or land, or to mortgage their land under a system called gerow. Under gerow, a landowner borrows against his land; however the lender maintains the usufruct as long as the debt is outstanding. As the borrower usually loses his chief means of repayment, in reality most farmers lose the use of their land for good.

2/ Source: "Lashkar Gah Household Expenditure Survey", Survey of Progress $1968 / 69$, Ministry of Planning, Kabu1, 1969. The actual disparity between urban and rural food expenditure may be greater. A study in a comparable area of Pakistan (Karachi in 1961) indicated a similar rural figure, but a lower urban figure ( 54.1 percent), see Ibid, Table 8 .

3/ Source: CINAM, Services for Children within Regional Development Zones - Research and Action, Experimental Activities at the Village Level, Vol. II, UNICEF, Kabul, 1973.

4/ Most surveys have been conducted on mothers and children who have come to health clinics. As these children are more likely to be 111 than children not brought to the clinics, surveys based on them are likely to bias the overall health picture. 
falls steadily from ages 2 to 5. Nevertheless, at age 4, more than 43 percent of the children sti.11 display either possible or overt malnutrition. It must be remembered, however, that by age 5 about half of the original births have died along the way. Those that achleve age five are a tough and battered lot, and include the more sturdy. In another rural survey of 248 school children in the north, only $g$ displayed no slgns of nutritional deficiencies.

3.20 It is difficult to form a conclusive picture of the nutritional situation. Evidence suggests that it is more severe in rural areas than in the towns and cities. This can probably be explained in terms of higher urban incomes, greater variety in the foods available, and closer proximity to health facilities., Deficiencies in iron, calcium and vitamins appear universal, as does the unsuitability of the diet on which children are weaned. Part of the problem is one of education; making mothers aware of the special nutritional needs of the young and making fathers aware of the special nutritional needs of expectant and aursing mothers. The consumption of milk in particular must be substantially increased. Other needs such as vitamin, mineral and protein deficiencies are more difficult to satisfy given the economic and physical environment of most Afghan families. Here, as well as for milk, there is scope for special distribution programs.

\section{(ii) Water}

3.21 Water is the key to life in Afghanistan. Practically every source of water is exploited and in the presence of assured water, land of even the poorest quality is settled. Water is used to the limit; the same source often provides water for irrigation, enimal and human consumption, and personal hygiene. The more fortunate villages have independent sources of water, springs or karezes which are usually quite clean and reliable. Others must share water from streams and rivers. The water flows through the villages in open, multipurpose canals (juis). Tests have shown that more often than not these canals are polluted before they even reach the village, and that if they aren't as they enter, they are when they leave. The least fortunate villages have no regular supply of water. In these villages water flows for a specified amount of time on a given day when it irrigates the fields, is used to wash clothes, and is stored in small reservoirs. These reservoirs (howz) are usually located in family courzyards beneath trees to reduce evaporation. Howz water has been found to be uniformly polluted. Some villages have shallow wells to zap eroundwater. The wacer from such wells is usually less polluted than water from juis or in the howz, but there is no guarantee that it is safe.

3.22 Polluted water has been 1dentified as a major cause of 11 lness and disease in Afghanistan. Only about 700,000 people, about 5 percent of the population, have access to public piped water systems. The supply of clean drinking water to rural villages is the responsibility of the Environmental Health Department (EHD) of the Ministry of Public Health. By mid-1977 EHD had installed piped systems in about fifty villages. Most of these are deep wells which feed distribution networks containing public standposts. It has been estimated that these systems supply about 100,000 persons. EHD has also installed about 750 hand pumps that are estimated to serve about 200,000 people. However, a recent sample survey by UNICEF found that 50 percent of 
the hand pumps and 60 percent of the power pumps were not operational. In such cases people had simply reverted to their original, usually polluted, sources of water.

3.23 The problem of polluted water is probably even more critical in urban areas. In Rabul city, before 1975, when the construction of modern piped water facilities commenced, piped water was available in only 14 percent of the houses (mostly the homes of the wealthy, and those with their own wells, pumps and storage tanks). Public plpes on the streets were used by only 28 percent of the households. Another 46 percent of the houses used public and private wells, while water was not readily available in 20 percent of the households. 1/ Unt1l recently, the only other urban centers with piped water were the capitals of two provinces with special development projects Belmand and Paktia. P1ped urban water supply is the responsibility of the Central Authority for Water and Sewerage (CAWS), a quasi-independent Authority under the Ministry of Public Works. It currently operates five fumctioning water supply systems, and is in the process of expanding into eight further centers. 2/ Other major centers and small towns have no 1 mmediate prospect of obtalning water supply systems however.

3.24 The principal reason driaking water is contaminated is because primary santation standards are so low. Few people in rural Afghanistan are aware of the links between improper sanitation and polluted water, and as a consequence water-borne disease is rampant. Dnder such circumstances investments in drinking water delivery systems and sewage disposal are of crucial importance. If these programs are to succeed there must be efforts to create an awareness of the importance of proper preventive health measures to induce the public to use and maintain the facilities once available. Inevitably it will take well beyond the present or even the next Plan period to reach the majority of the rural population. In the meantime, health education would also help to persuade the rural population to tackle the problems from within the community until such time as public services can be made avallable to all villages.

\section{(iii) Shelter and Fue 1}

3.25 In rural Afghanistan, housing rarely presents a problem. In the Lashkar Gah expenditure survey, it was found that rural families only spent on housing an average of 1.2 percent of their total expenditure. In urban families, this rose to 5.3 percent, and in the large urban centers it is undoubtedly far higher again. Rural house construction requires little cash: non-productive land is abundant, mud and straw are read1ly avallable, and much of the labor is provided by the family 1tself. Cash costs are limited to craftsmen and to the poplar trees used to reinforce the roof. Operating costs are $10 \mathrm{w}$, usually confined to remudding the roof every two or three years.

1/ CARE, op.cit., Appendix 3, p. 6.

2/ Functioning systems are in Kabul, Mazar-i-Sharif, Herat, Kandahar and Jala labad. 


\section{(iv) Public Bealth}

3.30 In few countries is the health situation as serious as in Afghanistan. Disease and 11lness are rampant, and the infant mortality rate is one of the highest in the world. So common are some afflictions 11ke malaria, measles and cuberculosis that like high infant mortality they are simply accepted as part of life, neither unusual nor preventable.

3.31 The disease and 1llness pattern is largely the result of two sets of inceracting factors; the ecological environment, and the faflure to appreclate the 1mportance of proper nutrition and personal hygiene. The few surveys that have been conducted suggest that incidence of disease is both region and season-specific. Representative of these surveys is the following compiled by doctors who accompanied an in-jepth socio-economic study of a large (populat1on 1,800) village in northern Afghanistan. Patients presented themselves with the following 11lnesses:

Table 13: SEASONAL INCIDENCE OF ILLNESS IN SANSIZ, 1972-73

\section{Diagnosis}

Respiratory 11lness

Digestive iliness

Liver disease

Skin disease

Eye disease

Locomotor system (arthritis, etc.)

Nutrition related (anemia, fatigue, etc.) Reproductive related

Circulatory

Other

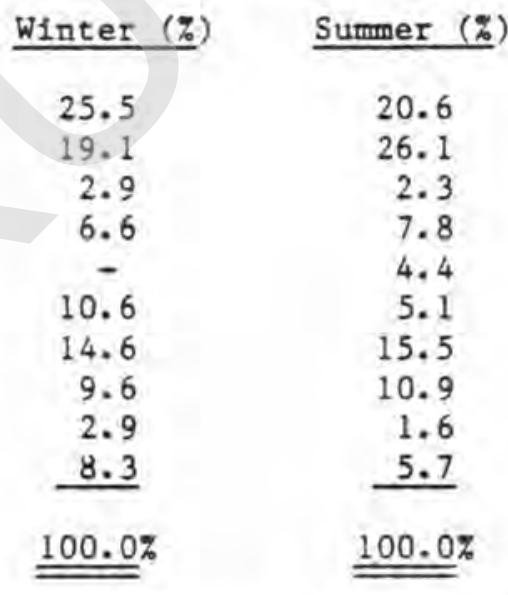

Source: CINAM, op.cit.

Several conclusions can be drawn from the survey: (a) Pespiratory and digestive 1llnesses are the two most prevalent complaints, accounting for almost half of the total. (b) They are both year-round problems, though as would be expected there is somewhat higher incldence of respiratory 11lness in winter and digestive 1llness in summer. (c) Malnutrition was noted as a symptom in about 15 percent of the cases. (In surveys where patients themselves were asked of their past 1llness, less than 1 percent mentioned malnutrition, or not enough to eat. Nor, in Afghanistan does malnutrition alone constitute grounds enough for admission to hospital.)

3.32 Studies 1nto the nature of digestive system 111nesses have revealed that they are for the most part water-borne. Dysentery, typhold and paratyphoid infections all are extremely common. An epidemiological survey of four rural villages indicated that 32 percent of the population were infected with 
different forms of Ascariasis including 11ver fluke, tapeworm and hookworms. $1 /$ Infection among children less than 10 years of age was 41 percent. Infection with amoeba was even higher - between 50 percent and 80 percent of the population had at least one form of amoeba, and some had four varieties. However, for most adults 1t was not particularly debilitating, over time their bodies had developed immunity to the agents. Among young children symptoms were widespread though; on the day of the interviews and tests more than 50 percent of children less than 10 years of age had diarrhea/dysentery, a far higher proportion than for adults. In towns and cities the problem may be much worse - In one Kabul survey 75 percent of the children under 18 years of age had Ascariasis. 2 /

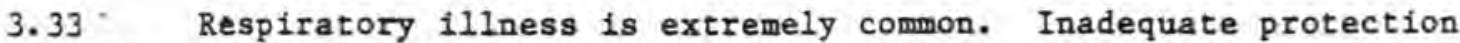
agaibst the cold, combined with undernourishment, makes people highly susceptible, and living together in crowded quarters makes transmission easy. The most coumon complaints are colds, coughs, pneumonia, and tuberculosis. Indications are that tuberculosis is widespread in Afghanistan. The four-village survey found that almost 50 percent of the population showed positive reactions to the antigens. Furthermore X-rays showed symptoms of pulmonary TB in 6.5 percent of the population. Actual incidence of tuberculosis would be much higher, were it not for the healthy outdoor life most Afghans lead. A tuberculosis institute is being built with aid from Japan.

3.34 Malaria is a major public health problem for about one fourth of the population. Although rarely fatal, it is nonetheless debilitating. In 1976, in a major outbreak in the Jalalabad, area, 20-25 percent of the population was infected, causing serious problems of labor shortages during the rice harvest. It is concentrated in three areas: (1) the Kunduz-Takhar region of the north; (2) the lowland provinces stretching from Nangarhar in the east around to Farah in the west; and (3) the foothill regions of the Bindu Kush. The problem is greatest in the former two regions, which include the main rice growing areas. Malaria is definitely on the rise. From a few hundred cases in 1966, malaria has risen to 85,000 cases in $1975 / 76$ and 123,000 in $1976 / 77$.

3.35 The highly endemic nature of so many serious illnesses, the general state of malnutrition and the inadequacy of health care have given Afgnanistan one of the highest mortality rates in the world; as high as 30 per thousand. As discussed earlier, Iife expectancy at birth is also extremely low -- 35 years on average. The ultimate objective of development in Afghanistan is a better and longer life for 1ts inhabitants. To raise life expectancy, it is apparent that the major thrust will have to be in the spread of preventive measures which reach large numbers of people which will reduce the need for programs which treat those who are already 111.

1/ Buck and Buck, Health and Disease in Rural Afghanistan, Baltimore: Johns Hopkins Press-1972.

2/ CARE, op.cit., Append1x 3 . 
providing information on the importance of clean water, proper nutrition and personal environmental hygiene. Literacy and education are necessary both to promote and to enable the population to adjust to the radical changes in their way of $11 \mathrm{fe}$, which will take place as the modernization of Afghanistan proceeds.

\section{The Level and Distribution of Income}

3.39 The success of any development strategy in Afghanistan will be measured by its impact on the living standards of the vast majority of the population. The efforts of the past have touched only a small minority who have been drawn into the modern sector in the urban areas. As the preceding section demonstrates, only a small proportion of Afghanistan's population has 1ts basic needs adequately met at present. Obviously the problem is most serious for the very poorest groupa, and the highest priority attaches to alleviating their situation. Some of the elements this would involve, like health care and education, can only be delivered effectively through national programs; however, many more including food, clothing and energy needs are more effectively delivered through the market. But as a mechanism of widespread distribution, the market can perform only as well as need can be converted into effective demand. To ensure that the needs of the poor can be satisfied through this channel it is necessary that they have sufficient purchasing power to do so. To the extent they lack the means to satisfy their needs, either incomes in general are too low, or they are distributed inequitably, In Afghanistan, both are the case.

3.40 The first step is to define poverty in the Afghan context and to identify the groups whose need is the greatest. The mission's calculations suggest that in order to purchase the basic necessities of daily subsistence, a disposable income, in cash or kind, of about $\$ 85$ per capita per annum is needed. (This compares with GNP per capita of $\$ 180$.) Those who are below this level fall into the category of absolute poverty. (The calculation of the threshold figure for absolute poverty is given in full in Volume II, Part II, Section 2).

3.41 Who are the poor and how many do they number? It is likely that at least 20 percent and perhaps as many as 40 percent of the population live in absolute poverty. The problem is probably less serious in the towns and cities, thorgh the available evidence is not conclusive. Income distribution data are only available for two urban centers, Kabul and Lashkargah, neither of which can be regarded as typical. Data drawn from an expenditure survey in Lashkargah, which is the centre of a rich agricultural area irrigated by the Helmand Valley Development Project, suggest that only 15 percent fell into the absolute poverty group in 1968/69, the years of the survey. Using the expenditure weights drawn from the Lashkargah survey to analyze data collected in a survey of Kabul suggests a higher figure of 30 percent. $1 /$ The urban poor

1/ Based on "Kabul Household Expenditure Survey", Survey of Progress 1968/69, Ministry of Planning 1969, see Volume II, Tables 14.2 and 14.3. 
would consist of casual laborers who do not have steady employment apd sman traders. $\$ 85$ a year translates to an income of Afs, 85 a day for an avervege Afghan family of 6 or 7 people, on the assumption of a six-day work veek. This compares with a wage rate which varied between Afs. 40 and Afs. 70 a day in 1977, depending on seasonal labor needs and the kind of work.

3.42 The only survey work done on the distribution of income in urban areas has been done in Kabul, and is unlikely to reflect the general urban distribution. The survey suggests that ircome is extremely skewed - the bottom 56 percent of all households earn only 15.0 percent of the income whereas the top 6 percent earned 49.2 percent (see Volume II, Table 14.2). This implies a concentration ratio of 0.53 . Information on other urban centers does not exist; however, the Lashkar Gah expenditure survey in 1968 indicated a relatively equal distribution of expenditure in that town. The top 6.3 percent of the households account for 17 percent of the expenditure, while the bottom 63.9 percent account for 41.6 percent. This is consistent with the general impression that outside of Kabul in which such conspicuous consumption as there is in Afghanistan is concentrated, there is relatively 11ttle inequality of expenditure as opposed to income, in the smaller towns and rural areas.

3.43 The problem of poverty appears more serfous in the rural areas. Based on small survey of 12 villages in 7 provinces undertaken by the Ministry of Planning in 1970, between 11 percent and 60 per sent of the population of these villages lived in absolute poverty. This survey is obviously far too limited to allow extrapolation to the national level; however, it does serve to 1 llustrate the extremely direct linkages between land per capita, average per capita incomes and the degree of absolute poverty. The data are shown in Table 15.

Table 15: AVERAGE ANNUAL PER CAPITA INCOME AND LAND AVAILABILITY, 1970

\begin{tabular}{|c|c|c|c|c|c|}
\hline Province & $\begin{array}{c}\text { Sample } \\
\text { Population }\end{array}$ & $\begin{array}{l}\text { Average } \\
\text { Per Capita } \\
\text { Income } \\
\end{array}$ & $\begin{array}{l}\text { Land- } \\
\text { Irrigated } \\
\text { Total } \\
\text { (Jer1bs) /b }\end{array}$ & $\begin{array}{l}\text { Equivalent/a } \\
\text { Fer Capita } \\
\text { (Jeribs) /b }\end{array}$ & $\begin{array}{l}\text { \% of Pop- } \\
\text { ulation in } \\
\text { Absolute } \\
\text { Poverty /c }\end{array}$ \\
\hline Baghlan & 1015 & 6670 & 2432 & 2.40 & 11 \\
\hline Kan dahar & 990 & 5631 & 2369 & 2.40 & 25 \\
\hline Kunduz & 1125 & 4508 & 2866 & 2.54 & 21 \\
\hline Parwan & 684 & 2653 & 632 & 0.92 & 48 \\
\hline Gha $2 n 1$ & 1633 & 2514 & 1746 & 1.07 & 59 \\
\hline Nangarhar & 1094 & 2041 & 1014 & 0.93 & 60 \\
\hline Laghman & 385 & 2671 & 493 & 1.28 & 47 \\
\hline
\end{tabular}

la Dry-farmed land productivity assumed $1 / 3$ irrigated equivalent.

$\frac{1 b}{l}$ F1ve jeribs equal one hectare.

Ic Based on 1969/70 absolute poverty level, calculated to be Afs. 2907.

Source: Ministry of Planning, Survey of Progress - 1970-71. 
The strong correlation between agricultural land per capita and incomes and poverty is borne out in Table 15 by a comparison of Baghlan, Kandahar, and Kunduz on the one hand with the remaining provinces on the other - the former have roughly twice the agricultural land per caplta and only about half as much of their populations are among the absolute poor.

3.44 Another important point emerges from this survey. The avallability of additional land often has a disproportionate effect on income, because it permits farmers to diversify production out of the major subsistence food crops and into high value cash crops. Baghlan, for Instance, has some of the best agricultural land in the country. There is also adequate irrigation water and rainfall. Adequate rain means that wheat can be grown on dry land, thus enabling the highly productive irrigated land to be devoted to cash crops, including rice, cotton and sugar beet. S1milarly, in Kandahar where the climate is conducive to grape-growing, 10 percent of the land in the survey was devoted to grapes which ylelded 42 percent of cotal income. Grapes were also grown by some farmers in Parwan. The farmers in Kunduz with their large farms were able to raise many cash crops, including rice, cotton, and melons alongside their wheat, but in Nangarhar, Ghazni and Laghman with much less land per capita, almost all the land was devoted to the production of rice and wheat, with some corn and vegetable production.

3.45 Who are the rural poor? Those who live off the land may be divided into four categories: landowners; share-farmers who recelve 50 per sent of the eventual crop and supply both inputs and labor; share-laborers who receive 20 percent of the eventual crop and supply only labor; and casual laborers who are employed 1rregularly. Many village income earners fall into more than one category. The average of land per villager is therefore a rather good index of the average living standard, since land represents a pool of potential income which is available for distribution. Given the low level of mechanization, large landowners have little choice but to give out the land beyond a size which can be operated by their own famlly, for sharecropping, or hire laborers. While $1 \mathrm{t}$ is therefore the ratio of total land cultivated to total population which is of major significance, its distribution is also inportant. Owner-operated land could by definition support double the population of sharefarmed land if it is assumed that the surplus income earned by the larger landowners would not generate any other employment in the village economy.

3.46 The ratio of land to population is a rathe complex one in Afghanistan. Thus irrigated land yields per hectare are on average about 4 times those of dry land. The introduction of 1 mproved wheat varieties on irrigated land almost doubles its return per hectare, while land that can be doublecropped with cotton and improved wheat would yield five times the return of irrigated land cropped with traditional wheat, and 20 times the return of dry land wheat per hectare. This is 1llustrated in the matrix contained in Table 16 below: 


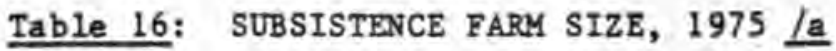

\begin{tabular}{|c|c|c|c|}
\hline & $\begin{array}{c}\text { Owner- } \\
\text { Operated }\end{array}$ & $\begin{array}{r}\text { Share } \\
\text { Farmed } \\
(50 \%)\end{array}$ & $\begin{array}{l}\text { Share } \\
\text { Labor } \\
(20 \%) \\
\end{array}$ \\
\hline $\begin{array}{l}\text { Dry land wheat } \\
\text { Irrigated land - unimproved wheat only } \\
\text { Irrigated land - improved wheat } \\
\text { Irrigated - double cropped cotton, wheat } \\
\text { and other crops with adequate 1rrigation } \\
\text { and improved conditions }\end{array}$ & $\begin{array}{c}21.1 \text { ha } \\
4.8 \\
2.8\end{array}$ & $\begin{array}{c}42.2 \text { ha } \\
9.6 \\
5.6\end{array}$ & $\begin{array}{c}105.5 \mathrm{ha} \\
29.0 \\
14.0\end{array}$ \\
\hline
\end{tabular}

la For details of farm models (based on 1 ha model) see Khanabad II Project, IBRD Appraisa 1 Report, Annex 18.

The data in Table 16 is drawn from the Kunduz area. Kunduz is one of the wealthier provinces cited in Table 15 and $1 \mathrm{t}$ is possible to relate the two tables although they use different units. Thus, Table 16 suggests that unimproved wheat on irrigated land requires 4.8 hectares or 24 jeribs for family subsistence. Using an estimate of 6 members per famlly, this would mean that 4 jeribs are needed per person. The requirement would of course be much higher with share-farmi.g or share-labor. In Kunduz, however, according to Table 15 only 2.5 jeribs are avallable per person. Thus even with equal 1ncome distributiou, Kunduz could not support its present population with traditional wheat. On the other hand, a shift to the most efficient technology in Table 16 would mean that less than 1 jerib is required to support each person. There is a good deal of double-cropping in the Kunduz area so that the data are quite consistent with this. It is more disturbing however to see the very low land availability in the Parwan and Nangarhar provinces. In these cases it is only a combination of very high levels of productivity and equitable income distribution which can result in a broad improvement of living standards.

3.47 Judging from the 12-v1llage survey, income distribution in the rural areas appears to be more equitable than in the urban areas or at least than in Kabul. The survey incicated that the bottom 50 percent of households earned between 15 percent and 25 percent of total income, while the upper 10 percent earned 30 percent to 40 percent. Land tenurial patterns did not appear to play a significant role in determining overall distribution; some of the most inequitable distribution appeared in villages where over 85 percent of the farmers were owner-operators, while some villages with between 40 percent and 50 percent sharecroppers showed no more inequity than other villages with only about 20 percent sharecroppers. It would not be fair to draw the conclusion from this that tenure plays no role in income distribution however. Its impact is almost certainly being masked by the more important effects of availability, distribution and quality of land. Other things being equal, the greater the percentage of sharecroppers among cultivators, the greater the percentage of land sharecropped, and the more stringent the terms of sharing, the more inequitable the distribution of income is likely to be. 
3.48 Land quality and availability per capita and distribution appear to be the major variables explaining the distribution of income in rural Afghanistan. A 1967 government survey of about half the landowners $(618,000)$ and half the cultivated land indicated the following distribution:

Table 17: LAND DISTRIBUTION IN AFGHANISTAN, 1967

$$
\begin{gathered}
\text { S1ze of Holding } \\
\hline \text { (hectares) } \\
0-0.5 \\
0.6-3.9 \\
4.0-19.9 \\
20.0-99.9 \\
100+
\end{gathered}
$$

Percent of Holders

40.0

40.0

17.8

2.0

0.2

100.02
Percent of Land

4.0

25.0

29.0

34.0

8.0

$100.0 \%$

Source: Smith, et. al., Area Handbook for Afghanistan, 1973 , p. xxxvi.

According to this study, the poorest 80 percent of the landholders own about 29 percent of the land. $1 /$ These figures are distorting, however, since no distinction is made between irrigated and dry farmed holdings. Dry farmed holdings are almost invariably larger; necessarily so, to bring equivalent farm income. In addition, the survey overlooks the varying potentials of different types of agricultural land; quite often only a fraction of owned and technically arable land can be farmed due to lack of sufficient water. Some 1rrigated land receives sufficient water to irrigate two crops while other land has enough for only one. Indications are that the distribution of the best agricultural land is not as skewed. The 12 village survey cited above was conducted in provinces in which soil quality was known to be good and in villages that farmed almost exclusively irrigated land. Agricultural conditions were thus more uniform and the overall concentration ratio for land ownership was 0.36 , considerably lower than the 0.69 figure derived from the above table. In some areas such as the southwest, there are known to be individuals owning thousands of hectares, all of it farmed by hundreds of sharecroppers. in these areas, the distribution of income is bound to be far more skewed.

3.49 What conclusions can be drawn about the level and distribution of income in Afghanistan? Obviously absolute poverty is a problem. As compared to a poverty threshold of $\$ 85$, the average rural per capita income derived in the survey of 12 villages, translated into current prices works out at about $\$ 120$. By comparison $1 \mathrm{t}$ works out at $\$ 180$ for the town of Lashkar Gah and $\$ 240$ for Kabul. And indications are that the gulf between Kabul and the rest of

1/ Actual distribution is likely to be more skewed given the tendency to underdeclare. 
the country is widening. The relative affluence of Kabul is understated by the figures since it is not only disposable income in which it shares disproportionately but relatively adequate government services, many of which are free or subsidized as well. This reflects a development strategy which has been geared to creating a modern sector operated by the Kabul-based bureaucracy, instead $O_{2}$ modernizing the traditional economy through a decentralized administrative approach. The solution is obviously not to impoverish Kabul, but to shift priorities to the needs of regional and rural development.

3.50 The message is clear. Per capita average levels of incone and productivity in the rural areas are simply not high enough. For those who fall into the category of the absolute poor this means serious deprivation in bad crop years, and malnourished nursing mothers and children even in good ones.

- Even for the majority of the rural population, who can afford the minimum needs of food, ciothing and shelter, there is little surplus to be saved and re-invested, or, for that matter, taxed so that the Government can supply education, health services and clean water. Afghanistan's development strategy must combine higher rural productivity with a direct effort to meet bastc needs. The redistribution of land, the major rural asset is critical to insuring that the benefits of higher productivity in the future will be spread among the population, though its immediate impact on improving living standards is likely to be limited.

D. Atracking Poverty

3.51 The reader can be forgtven for finding the description of various aspects of life in Afghanistan a depressing one - indeed with respect to standards of education and health, an appalling one. Yet the traveller in the Afghan countryside would not find his experience depressing, On the contrary he would appreciate many of the strengths of the traditional way of life, particularly the sense of closeness between the individual and his community, which has been all but lost in many modern environments. Poverty in Afghanistan is for the most part the poverty of a traditional rural society untouched by development and unchanged for centuries. This is not the poverty of displaced rural squatters or teeming urban slums. It is a poverty that is accepted as the inevitable accompaniment of human existence. The policy-maker has in his hands knowledge and innovaticns which could substantially improve the quality of life in traditional society - modern medicine, education, production inputs and techniques. The test is to introduce these in a way which is consistent with, and builds on the strengths of modern Afghanistan.

3.52 The development which has taken place so far has been of the enclave type, drawing off participants from the traditional society, while leaving the basic fabric of village life unchanged. It is a far easier course of action than going to the villages and attempting to change them from within. This report advocates the latter approach, of bringing improved health, literacy, food, shelter, fuel and consumer goods to the village and of increasing rural productivity and income. To be effective, such an approach must take account of the special character of rural Afghan society. There is little real alternative, however, if living standards are to be raised. The strategy of urban-oriented capital-intensive development cannot reach a significant proportion of the population within an acceptable time-frame. 
3.53 The elements of thir strategy emerge clearly from the preceding discussion. The most obvious element of the approach is to raise levels of output and productivity. Chapter II argued that earlier attempts had not succeeded or had only limited success. The past strategy was directed at food self sufficlency through higher wheat production and a supporting industrial base substituting for imports. Infrastructure was based largely on the needs of industry, through the construction of major roads and the provision of ample energy supplies to Kabul and other industrial areas. Afghanistan's major production potentials sppear to lie in the processing of agricultural surpluses. These are smaller scale activities, which have been shown to be well within the managerial capabiltties available in the country. They would also have greater benefits in employment terms than the capital-intensive projects pursued earlier. Of course this strategy would also imply a quite dfferent development of infrastructure, of educational factlities, of banking and communications. These would have the concomitant advantages of enabling basic needs to be met more quickly and widely than otherwise.

3.54 The second element of the attack on poverty in Afghanistan is a program which is directed at meeting basic needs. These needs are being met substantially in Kabul, hardly at all anywhere else. It is understandable that the capital should have better facilities than other cities; it is the logical way for major nation-wide programs to get off the ground. It is less understandable that after these programs have been operating for ten or fifteen years they should still focus almost exclusively on the Kabul area. Furthermore the provision of these needs in the Kabul area is heavily subsidized by the Government although the main beneficiaries are rarely the neediest sections of the population. The emphasis has been on bullding high quality hospitals in the capital rather than small basic health centers in the rural areas, on urban high schools rather than rural primary schools, on food subsidies for civil servants rather than food supplies for inaccessible areas. The analysis needs to be turned around. Unt1l now there has been a central program organized and it has been planned to spread it judiciously from the center outwards. Unfortunately the lack of implementation capacity has often meant that $1 \mathrm{t}$ has remained confined to the center. The approach must begin by analyzing what the villager needs and evolve feasible delivery systems to supply those needs.

3.55 These two objectives can best be achleved through a program of regional and rural development. Such a program would begin with the planning process. Local production potentials must be idencified, infrastructure needs must be delineated and the gaps in social services must be assessed. The next stage would be to prepare investment projects, to decentralize administrative structures and to formulate appropriate incentive policies. The traditional system in Afghanistan has strong elements of community participation which could provide a precedent for tapping local initiative. Such a strategy would obviate the need for difficult choices. The same infrastructure that enables small processing units to be set up in the market towns can be used to bring health care to the villages. High schools and colleges will train a new generation of local leaders, capable of playing the major part in the new industries and social services. 
3.56 Two other areas will require attention, not so much to promote development, as to safeguard the gains over the longer-term. These are income redistribution and population planning. While the immediate effe of re-distributing income and assets in Afghanistan would be limited given the low level of aggregate income, some movement in this direction will be a necessary condition of 1nsuring a wide distribution of the future benefits of growth. Land reform in particular has a role to play. in providing motivation for investment. Redistributing income also implies a reorientation of the fiscal system. At present the role which the fiscal system is playing is unrelated to income distribution objectives. The effect is often to provide free or subsidized services to those who could afford to pay economic prices. The result is that the distribution of services to those who cannot afford to pay is likely to be held up in the future by limlted financial resources. While the tax system in Afghanistan is generally progressive with respect to income, its incidence on the rural population is high relative to public expenditures in the rural areas. Since most of the poor are located in the rural areas, the effect of drawing income off from these areas to pay for industries and public services in the cities is likely to be regressive.

\subsection{The final element is the need for population planning. Over the} long-term Afghanistan w11l find it difficult to maintain adequate growth rates of per capita income in the absence of effective measures to contain the growth of population. Afghanistan's current rate of population growth is 2,2 percent per annum. If it is assumed that GNP grows at 4 percent per annum and the population growth rate is unchanged, then by the turn of the century, per capita income will have reached $\$ 260$. W1th population growth reduced to 1.2 percent per annum, per capita income would be subtantially higher at $\$ 335$. A similar impact could of course be achieved by a one percentage point rise in the GNP growth rate. The difference is of course even more striking if projected over a longer time-span. But the argument fur population planning is also a component of meeting basic needs in Afghanistan. Studies indicate that the number and spacing of births in Afghanistan have had detrimental effects on the health of both mothers and children. Family planning programs are likely to be an important aspect of the overall effort to improve health.

3.58 Subsequent sections of this report will attempt to delineate the specifics of this approach. It is obviously rather different from the approach which has been spelled out in the Seven-Year Plan. Yet the differences are in many cases more in presentation than in substance. Thus there is litfle question of the commitment of the leadership to rural development, to meeting basic needs, to higher agricultural output, to land reform. Most of these programs are included in the Plan along with the large capital-intensive projects. In the past when these programs have been included they have often been held up for lack of administrative capacity, while the big projects have gone ahead. Perhaps being less visible they did not attract the 1nterest and priority which would have led senfor administrators to cut through the morass of red tape which surrounds decision-making in Afghanistan. And perhaps it is in the different sense of priority that this Report does indeed differ from the Plan. 


\section{THE AGRICULTURAL ECONOMY}

\section{A. Agriculture in Afghanistan at Present $1 /$}

4.01 Present day agricultural practices in Afghanistan have been established over many centurles. Only in the past few decades has any notable new rechnology been 1ntrcduced, in the form of modern engineering construction for water storage with improved water distribution for irrigation, and development of intensive crop production using chemical fertilizers. Thus an essentially pastoral system dominated by the seasonal migration of flocks of about 20 miliion sheep and goats between winter grazing on the semi-arid plains and summer pastures in the rugged mountain ranges has been progressively strengthened by the growth of a sedentary 1rrigated cropping base. Very well adapted husbandry practices and associated breeds and varieties of livestock and crops have enabled the extremely hardy population to gain a reasonable subsistence living from a rather difficult agricultural environment. At this stage over 80 percent of the population are rural, 11 ving in about 20,000 villages containing more than 1.2 million farm families in the lowland valleys, and nearby plains, and providing winter bases for about 200,000 nomadic families. Villages are located where water can je obtained by diversion from rivers, or from underground sources chrough karezes or wells, to enable irrigated crop production, primarily wheat, but with cotton, fruits and vegetables increasing in importance. Although irrigation structures are rather primitive, farmers have developed quite impressive skills in irrigation practices. Thus just 2.6 million ha of irrigated land provides 85 percent of all food and industrial crops, while crop residues and forage supply supplementary and winter feed for the national flocks and herds. Of the country's total land area of about 65 million ha, arable land is estimated at 8 million ha, of which about half is planted annully due to lack of irrigation water and the need to fallow rainfed areas. The extensive seini-arid plains and mountains provide over 50 million ha for winter, spring and summer grazing.

\section{(1) Physical Resources}

4.02 Topography and climate together impose severe limitations on land use in Afghanistan. The Hindu Kush mountain range occupies the central and northeastern parts of th country rising to an elevation of over 20,000 feet in the Pamirs of the Wakhan Corridor with the land falling away to 1,000 feet along the banks of the Amu Darya river. The rugged central mass of steep ridges and gullies carry sparse vegetation, with the main river systems flowing down to wide arid plains which fan out to the frontiers on the northern, western and southern periphery. The climate is arid continental, characterized by hot dry summers and cold winters when all precipitation

1/ For a more detalled description see Bank Report No. 848a - AF.

"Afghanistan: Opportunities for Agricultural and Rural Development Sector Report". 
occurs. The western desert areas receive less than $100 \mathrm{~mm}$ annual rainfali increasing eastwards in the higher elevations of the Hindu Kush to $1,170 \mathrm{~mm}$ at Salang. Above the 9,000 foot contour most of the precipitation is snow which serves as natural water storage, melting to provide irrigation vater during spring and sumer. A particular feature of the climate is the wide variation in the amount of ralnfall between years and its distribution during the season. Low rainfall in $1969 / 70$ and $1970 / 71$ caused very serious reductions in cereal crop yields in $1970 / 71$ and $1971 / 72$ while the effect on pastures was even more disastrous causing sheep losses estimated at 8 million head or 40 perctat of the national flock. Temperature varlations, with an average range from 30 degree $C$ in JuIy to 3 degree $C$ in January, impose further constraints on husbandry practices. In some areas, during the winter from November to March, temperatures may fall below -20 degree $C$ so that growth of winter wheat, sown and germinatę in November, can be inhibited until the following spring. Most of the arable areas below the 5,000 foot contour experience an average of 240 frost-free days. In the western desert areas extremely low humidity in the hottest summer months causes very high evaporation which is accentuated by strong winds which blow almost continuously between June and September. In the absence of natural wind breaks, mud walls are constructed in the irrigated areas to provide protection to crops and orchards. Soils in the major river valleys are mainly alluvial while extensive foot hill areas in the north, originating from weathered loess, are cultivated for rainfed wheat. Soils are generally highly alkaline, low in organic matter, nitrogen and phosphorus but, where there are no drainage problems, are very suitable for intensive irrigated cropping once they are improved through the incorporation of alfalfa in the rotation. $1 /$

\section{(ii) Farmers and Farming Systems}

4.03 Afghanistan's population is essentially rural based and unlike many developing countries, the rate of migration from the country to towns is relatively 10w. Indeed with the exception of the capital, Kabul, the towns maintain intimate ties with their farming hinterland for which they provide market outlets, service centers and sites for agro-processing industries. Most towns and villages are located in the center of intensive irrigated areas and the agricultural population of farmers, sharecroppers and wage labourers live in these centers with few living in isolation on their holdings.

4.04 On the basis of the mission's estimate of Afghanistan's present population of 14 million, sedentary rural dwellers number about 10 anillon and nomads about 1.5 million. Allowing for some urban migration, the agricultural population is probably growing at nearly 2 percent annually which shows the need for increasing employment opportunities through land development, expansion of irrigation and intensification of farming systems, more rural industries and handicrafts. To complement seasonal peak labor requirements labor

1/ See Volume II, Tables 7.1-7.4 for climatological data and statistics on land resources and land utilization. 
intensive programmes to improve village infrastructure and services should be designed to provide off-peak employment. At present many villages lack road access and are often cut off completely by snow for many months in the winter. Few villages enjoy medical facilities, a hygienic drinking water supply or electricity, and there are only 3,300 village or primary schools and less than one quarter cf primary school age chlldren attend school. Very few girls attend school at any level. Literate farmers are few and far between.

4.05 Although Afghan farmers are rarely able to read and write or keep simple farm accounts, it is generally recognized that they are hard working and have developed a high level of technical skills within the limitations of traditional farming practices. They are responsive to price incentives for their "crops though their first concern is to produce sufficient food (wheat) for family needs. The great majority of the estimated 1.2 million farm families live on holdings varying from 0.5 ha to 5 or 6 ha of cultivable land. Their very limited resources inevitably cause them to be rather suspicious of innovations and therefore practical demonstrations of 1mproved practices, e.g. superior varieties and use of fertilizers, are needed to induce them to risk changing from traditional patterns. Like farmers in many developing countries the Afghan farmer has some reservations about motives and capability of central government services to provide worthwhile assistance. At the same time, he is inclined to expect such assistance to be provided free whether it be an improved irrigation system (for which no direct charges have yet been imposed) or even for inpu:s such ds chemical fertilizers for which there is a rather high proportion of overdue loan repayments to the Agricultural Development Bank (AgBank), though there has been a constant improvement in loan recoveries.

\section{(iii) Earming Systems}

4.06 There are basically two distinct husbandry systems depending on the suitability of land resources: intensive crop production based on irrigation, and extensive pastoral husbandry based on transhumance movement of sheep and goat flocks between winter and summer grazing areas. While the technology and skills employed in these systens are quite distinctive it is the close relationship for mutual benefit which needs to be fully appreciated.

4.07 The transhumance or nomadic system covers about 80 percent of the sheep and goat flocks, estimated to number 20 million and 3.3 million respectively, which move each season from their winter grazing on the plains to the high mountain pastures of the Hindu Kush. The flocks travel almost entirely on foot between winter and summer grazing grounds, which are often more than $200 \mathrm{~km}$ apart, and cover distances of 6-10 km dafly. Mortality is high and productivity low due to disease and the low level of nutrition resulting from overgrazing despite the fact that great care and skills are exercised by the shepherds in flock management. Extremely hardy and thrifty animals have survived by the process of natural selection. Only the crop residues, mainly wheat and barley straw, and a small amount of range hay are available for supplementary winter feeding to the transhumance flocks. Goats, which 
generally run in mixed flocks with sheep, have been more successful than sheep in surviving drought and numbers are on the increase. Although not considered as commercially valuable as sheep they do make a substantial contribution particularly in meat and milk for home consumption.

4.08 Sheep flocks include about 30 percent karakul which are multipurpose animals and are managed in the same way as other transhumance stock. Careful selection of karakul lambs to be retalned for breeding has to be made within a few days of birth when the majority of male lambs and about 25 percent of females are slaughtered for their pelts. In response to the much higher price for mutton there is a tendency to raise more karakul lambs for meat which, while.increasing the pressure on range grazing and reducing the avallability of ewes' milk for human consumption, is enabling high standards of pelt quality to be maintained.

4.09 The estimated 1.5 million nomadic population are almost entirely dependent on their flocks, though limited cash income may be earned by providing casual labour for crop harvesting. A dynamic relationship between nomads and sedentary farming can be seen in a number of richer nomads buying irrigated land, while at the other extreme poorer nomads who lose their small flocks during droughts are forced to find employment on irrigated farms. About 20 percent of flocks are sedentary, remaining close to their owners' villages and feeding entirely on crop residues and nearby range grazing.

4.10 Irrigated cropping is the other distinct farming system, though it is also of crucial importance to the pastoral way of life. Afghanistan is a land of small farmers (although in terms of legal ownership a number of landowners may have title to a disproportionately large area) with about $1.2 \mathrm{million}$ cultivators operating an average of 3.0 ha of arable land each. Historically the major production input which the farmer could provide was his own labor and the result has been a very labor intensive irrigated husbandry system with water diverted from rivers and springs and human labor and animal draught for cultivation. Again, historically, first priorlcy has been given to wheat production with the objective of ensuring famply needs, of about 1.0 ton annual$1 y$, or the produce of about one-third ha of a single irrigated crop. Wheat straw provided feed for cattle and transhumance flocks. The impact of modernization on this small-farmer, traditional, but intensive system, has been defintely favorable to improving its viability through still more intensive husbandry methods. Notably this change has resulted in the cultivation of higher value crops; cotton, sugar beet, grapes, vegetables and higher yielding wheat varieties, with increasing use of chemical fertilizers and chemical pesticides. While farm incomes are extremely modest and vary greatly, a family fart of 2 ha of good irrigated land is capable of providing the family with basic food needs and a cash income of Af 35,000 I/ which may be compared

If Based on a holding of 2 ha good irrigated land, with adequate reliable water enabling yields of 3 tons wheat and 2 tons cotton, 1.17 ha planted with cotton provides the main cash income of Af 35,$000 ; 0.33$ ha provides family wheat requirements; $1 / 2$ ha for forage crops for livestock, and vegetables. 
to a laborer's income of Af 15,000 (at Af 50 average daily wage rate). There is considerable scope for further intensification and tharefore of raising farm incomes and extending the range of viability of a family unit to smaller holdings.

\section{(1v) Crop Production}

4.11 Of the estimated 1975 GDP of Af 106 b1ll1on, about half was contributed by the agricultural sector. Agricultural primary products, or goods and handicrafts made from agricultural raw materials, amount to 80 percent of total exports. Over the past decade performance has been somewhat disappointing in that food production of which cereals are the major component, has falled to keep pace with population growth $1 /$. In 1976, domestic cereal production, though 28 percent above the average of 1961-65 in aggregate terms was 6 percent lower in per capita terms. This is in part explained, however, by acreage expansion and increased production of other crops. Non-cereal crops, of which cotton is by far the most important, have steadily expanded in output by more than 40 percent over the previous decade.

4.12 Cereals - wheat, rice, maize and barley - still, however, dominate the cropping pattern occupying about 83 percent of the annually cropped 2.5 million ha of irrigated land and almost all of the 1.3 million ha of rainfed land. Fruits and vegetables, industrial crops particularly cotton and sugar beet, and alfalfa and other forage crops occupy the remaining 430,000 ha of irrigated cultivation. A special program to increase wheat output through the use of 1mproved varieties and chemical fertilizer, which was initiated in the mid-1960's, has succeeded in raising irrigated wheat yields from an average of 1.3 tons to 1.8 tons/ha.

4.13 Cotton is the most important industrial crop and, in response to strong export demand, which has been reflected in incentive prices to farmers, production has shown a steady annual growth from 71,000 tons of seed cotton grown on 55,000 ha in 1968 to 165,000 tons from 112,000 ha 1 in 1976 . Commerc1al cotton growing has been long established in the northern provinces of Kunduz, Takhar and Baghlan which produce about 50 percent of the total output, with ylelds of over 2 tons/ha in Kunduz and Baghlan. However prospects for further expansion of cotton production in the western and southern areas, such as Herat and Relmand are favorable.

4.14 Wheat and cotton compete with each other for the use of 1rrigated land and farmers are very responsive to relative price changes in deciding whether to switch from one crop to the other. The producer prices which have ruled for the past few years of Af 6.5 and Af $15 / \mathrm{kg}$ for wheat and cotton respectively, have favoured cotton as it is generally accepted that an equilibrium price relationship would be about $1: 2,1$.e. wheat would need to be ralsed to Af $7.5 / \mathrm{kg}$. Apart from relative prices most farmers give first

1) See Volume II Table 7.5, "FAO Agricultural Production Indices". 
priority to growing sufficient wheat for family needs and only after this is assured would there be any switch to cotton. Thus farmers with several hectares of 1rrigated land can be more flexible in their cropping patterns.

4.15 Sugar beet has been cultivated commercially for many years in the vicinity of the only processing factory located at Baghlan. Current production of about 110,000 tons grown on 5,000 ha is $11 \mathrm{mited}$ by the capacity of the factory. The run down state of the equipment in the factory has resulted in poor rates of extraction of around 12 percent. Since sugar imports exceed 50,000 tons annually (at a cost of $\$ 36$ million in $1975 / 76$ ), the possibility of expanding domestic sugar production clearly merits careful attention. However sugar beet and cotton are in direct competition for good irrigated land and, at present world prices of the two crops, cotton production would be somewhat more attrdctive both to the farmer and the national economy $1 /$. However in the interest of a diversifled farming system allowing.good crop rotations and varied by-products for stock feed, there appears to be a case for expanding sugar beet cultivation. During the present Plan it is unlikely that production of sugar beet in the Baghlan area would be increased to more than 200,000 tons which will be the capacity of the replacement sugar factory which is proposed to be built. Sugar cane growing is limited by climate to the Jalalabad area and there appears to be little prospects of increasing production of cane above the present 65,000 tons, which is processed by traditional methods into "gur".

4.16 Tree fruits, nuts and vines are grown commercially in Jalalabad, Mazar-i-Sharif, Kandahar and Parwan. Grapes account for about 30 percent of total fruit production, yielding both good qualicy table grapes and raisins. Mulberry is widely grown and its sun dried berries are an important item of diet, while it also supplies firewood and is supporting an infant sericulture industry. Melons are extensively cultivated and rank next to grapes in exports of fresh fruits. A wide varfety of deciduous fruits; citrus, olives, nut trees including walnut, almond and pistachio, also contribute to total annual fruit production of 880,000 tons. Although the climate is generally favourable for irrigated fruit cultivation there is considerable scope for improving agronomic practices including greater use of fertilizers, disease control and better quality root stocks.

4.17 Vegetable production is estimated at 720,000 tons of which about 40 percent is potatoes. As exports are currently prohibited (except for a small quota which has been given to the Afghan Vegetable Export Company) virtually all vegetables are consumed locally giving a gross average per capita avallability of $43 \mathrm{~kg}$ per annum. Oilseeds output, mainly linseed and sesame, is

1/ On the basis of producer prices for cotton and sugar beet of Af $15 / \mathrm{kg}$ and Af $1,000 / t o n$ respectively at yields of 2 tons and 25 tons respectively per ha, gross value of production of cotton is 20 percent higher than sugar beet. Production costs of cotton would be somewhat higher due to harvesting expenses. Valuing cotton and sugar at 1976 prices, export of two thirds of a ton of cotton lint (i.e. the processed output from one hectare) valued at $\$ 1,600$ per ton, compared to the import cost of 3 tons sugar at about $\$ 300 /$ ton shows the foreign exchange earned by producing cotton to be 18 percent h1gher than the foreign exchange saving from sugar. 
about 40,000 tons. Based on successful trials, preference is to be given to their substitution by sunflower.

\section{(v) Livestock Production}

4.18 Animal products including wool, hides and skins, karakul pelts, and casings constitute about 15 percent of the value of all exports, while woolen carpets contribute a further 7 percent. All meat and milk (apart from 1mported donated milk products) are provided by domestic sources, and constitute an annual per capita level of $11.5 \mathrm{~kg}$ meat and $60 \mathrm{~kg}$ milk equivalent. Fresh milk is malnly consumed by families who own cows, and sheep's milk is only available in the country areas for about 2 months in the spring after lambing. Sheep numbers. fell by about 40 percent as a result of the two year drought 19711972 , and the subsequent bullding up of flocks has resulted in reduced numbers available for slaughter as well as less karakul pelts for export. Although cattle are maintained primarily as draught animals, the number of work oxen in Afghanistan may prove inadequate to provide the power needed for crop expansion programs and there could be a need for expanded use of tractors. This should be the subject of careful study however. Poultry husbandry is almost ent1rely backyard scavenging while efforts to expand intensive commercial poultry production have not as yet made much progress; as a result poultry meat is relatively expensive.

\section{(vi) Forestry and Fisheries}

4.19 Natural forests, which cover an area of 2 million ha including 0.3 million ha of wild pistachios in Badghis, are estimated to contain wood reserves of about 30 million cubic meters. The timber forests are located on the eastern slopes of the Hindu Kush and Safed Koh, mainly in the provinces of Konar and Paktia. It has been estimated that only about 500,000 ha are economically exploitable. The rate of felling, which is estimated at one million cubic meters annully with 60 percent vastage, is much higher than regeneration and reforestation with the result that reserves are rapidly being depleted. Traditionally Afghan farmers maintain stands of poplars in irrigated areas and along the banks of rivers, streams and canals and this has been an important contribution to meeting the country's requirements of fuel wood, bullding poles, frult cases and even furniture.

4.20 Fish production is very limited for obvious reasons though there are prospects for fish culture in some of the rivers and dams.

\section{B. Constraints to Development}

4.21 The performance of the agricultural sector over the past decade has been disappointing. The very large investments in mafor irrigation structures did not realize quick returns through increased crop production because of the failure to gear them to land development and farming operations. Technical difficulties encountered in irrigation development are dramatized in the serious salinfty which has appeared in large areas brought under irrigation 
In parts of the Helmand Valley through the fallure to incorporate an adequate drainage system in the project. However, the Belmand Valley developmeat, in spite of its costly faults, does represent a major landmark in Afghanistan's recent economic progress. The project has provided the training ground for most of the present Afghan professional irrigation development personnel and has given them valuable experience in planning, implementation and operation of a major land and water project. Whatever the past failings, the Helmand Valley now makes an important contribution to the national economy, notably in supporting a rapidly growing cotton/textile complex and providing a substantial surplus of wheat.

4.22 In spite of a major program inftiated in the $1960^{\prime}$ s to expand wheat production through the use of high yielding varieties, notably Mexipak, domestic production has maintained a precarious balance with the country's needs necessitating some imports in most years with critical shortages in the drought. years of $1971 / 72$ and $1972 / 73$ when 200,000 tons had to be imported each year and many people suffered from severe food shortages.

4.23 The constraints have been identified in a number of World Bank sector studies and reports $1 /$ and indeed are well recognized by the Government in the development proposals for agriculture included in the First Seven-Year Plan. The most critical among the natural constraints is the unreliable rainfall. Uncertainty about the level and frequency of rainfall for winter sown izops and pasture regeneration, makes the timing of agricultural operations extremely critical and restricts the possibility of double cropping in some parts of the country. In the eight year period 1968/69-1975/76 average rainfall was $362 \mathrm{~mm}$ but in two successive years $1969 / 70$ and 1970/71 precipitation recorded was 29 percent and 35 percent lower than the average, with total. wheat production of only 86 percent and 78 percent respectively of average production in 1971-1976. Better than average precipitation in subsequent years has enabled wheat production to increase to well above average levels. Apart from wide variations in year-to-year national average precipitation, differences are equally wide between different parts of the country, and during different times of the year. For the main rainfed cereal growing areas, February to April are critical months when inadequate rainfall can cause serious problems. This occurred in 1977 and resulted in almost total failure of dryland crops in the northern areas.

4.24 Although farming efficiency has certainly advanced in the BaghlanKunduz area and the Kabul river basin, in much of the country farming practices are of a low standard both under irrigation and rainfed conditions due to lack of good seeds, limited use of chemical fertilizers and pesticides, poor animal health and husbandry practices and the absence of a rotation system which will allow integration of livestock with crop production at the farm level. As the majority of livestock are owned by pastoralists cropping patterns inevitably include very litcle forage crops. Farming practices are still very much conditioned by traditional attitudes in rural societies

I) Bank Reports Nos. 848a-AF, 1324-AF and 1490-AF. 
where 95 percent of the population is illiterate. Reluctance to innovate is undoubtedly yielding to the limited efforts of extension staff and the progressive though slow impact of education, communications and contacts which bring farmers into the market economy. Although great improvements have been made over the past two decades in main arterial routes, lack of access to remote areas persists and in many cases even areas close to urban centers are inaccessible because roads and tracks become impassable to motor vehicles during winter. The continuing belief in and indeed need for self-reliance in basic food production is therefore reflected in priority being given to subsistence wheat culcivation to supply family needs.

4.25 The structure of farm ownership and tenure act as disincentives to improved farming in a number of ways. At the one extreme, large landholdings are farmed by tenants and sharecroppers under inequitable conditions which do not encourage investment in land development or the use of modern production 1nputs. At the other extreme, there are many small, fragmented holdings with multiple ownership resulting from traditional tnheritance laws. In many cases these do not constitute viable production units. The new land reform law proposes to set ceilings on land ownership and reallocate land above the ceiling in smaller holdings. Although it is difficult to be optimistic about the implementation of the land reform program, it could, if pursued with determination, result in a more equitable farm structure and more intensive production. The land reform law does not address itself adequately to the problems caused by present tenancy and sharecropping arrangements, and initiatives in this area should be a major components of future changes in the policy framework of the agricultural sector.

4.26 Perhaps the most serious land tenure issue is water rights. The traditional system results in inequitable water distribution favouring landowners nearer the heads of canals who may overwater crops while farmers towards the bottom end of the system frequently receive inadequate water. This situation also militates against making improvements to the water distribution system because landowners at the top end who of ten have most influence in the village, feel they would not benefit and would probably therefore not contribute to the cost of improvements. To date only a small part of the country's irrigation system has benefitted from the program of smal1-scale irrigation improvements which has been in progress during the past two decades, and the current Plan, if fully implemented, would affect only 400,000 ha or only 12 percent of the total irrigated area. Thus the greater part of the irrigation system will continue for several decades to suffer from lack of storage reservoirs, primitive diversion and distribution systems, ifttle exploitation of groundwater resources and inefficient and wasteful water use on the farms,

4.27 At this early stage in adoption of modern faming practices the shortage of rechnical and specialist agricultural skills is particularly noticeable. As mentioned in para 4.24 above, the present generation of farmers has been cautious in adopting new techniques, particularly in using expensive inputs like chemical fertilizers. The Ministry of Agriculture's 
extension staff although adequate in numbers at present, lack the logistical support (housing, transport and equipment) and the technical training to provide adequate advice particularly in farm planning and management. Livestock production has suffered from lack of veterinary services.

4.28 Systematic agricultural research is in its infancy and as yet is totally inadequate - in specialist manpower, facillties and clearly defined, problem oriented programs - to provide the basic technical and economic guidance which agriculture urgently needs. Primary responsibility for research lies in the Ministry of Agriculture which has 10 regional research stations employing about 120 professional staff. A major part of the research stations' effort and land has hitherto been devoted to raising foundation seed and fruit tree root stocks, though much of this function has now been taken over by the Afghan Seed Company. In the view of the World Bank, research work has sutfered from a critical shortage of finance and equipment, frequent moves of key personnel and lack of overall direction and continuity of specific programmes.

4.29 Some general institutional weaknesses in the agriculture sector are already well on the way to being eliminated with AgBank, the Afghan Fertilizer Company and the Afghan Seeds Company playing an effective role in delivering and financing essential inputs such as seeds, fertilizers and chemicals, veterinary drugs and mechanical equipment. However, the Plan foresees AgBank providinc oniy Af 2.1 billion by $1982 / 83$ in total short-term credit which is only about half of the cost of fertilizer which should be used in that year. Insufficient credit and inability to finance inputs from their own resources has limited farmers' ability to intensify production.

4.30 The overriding constraint to the development of Afghanistan's agriculture appears to be the Government's inability to establish a consistent policy framework and provide effective supporting services. Although the shortage of trained and experienced agricultural professional staff at the policy, planning and management level has undoubtedly been a serfous problem it is also crue that existing skills available in the country have not been urilized as effectively as they could. Historically the Ministry of Agriculture has been given the task of initiating and implementing development programes for the whole of the agricultural sector, but has never been given the necessary authority and resources. As a result of its inability to carry out its true functions, the Ministry's responsibilities have been reduced by hiving off a number of activities to specialized institutions which have a degree of autonomy and freedom from bureaucratic procedure. While a certain amount of decentralization is clearly desirable there is a real risk of lack of coordination, and duplication of extension and research efforts; for example, giving the new Ministry of Water and Power responsibility for onfarm water use appears misconceived as water should be treated as just one of the important farming production inputs. The responsibility of the Ministry of Agriculture for policies and planning for agricultural sector development, for overall coordination and supervision of Government agencies implementing agricultural projects and programs and for the provision of national services, notably research, extension, crop protection, animal health, economic studies and surveys and market information, has not been firmly established. 


\section{Potential for Agricultural Development}

\section{(i) National Objectives}

4.31 The First Seven-Year Plan (1976/77-1982/83) defines the main objectives for the agricultural sector as: increasing output of food products, notably wheat, and of industrial raw materials, both for domestic consumption and processing, and for export. The increases in physical output required to achieve these objectives are shown in Table 18 below:

Table 18: PLAN AGRICULTURAL OUTPUT TARGETS

(1n thousand tons)

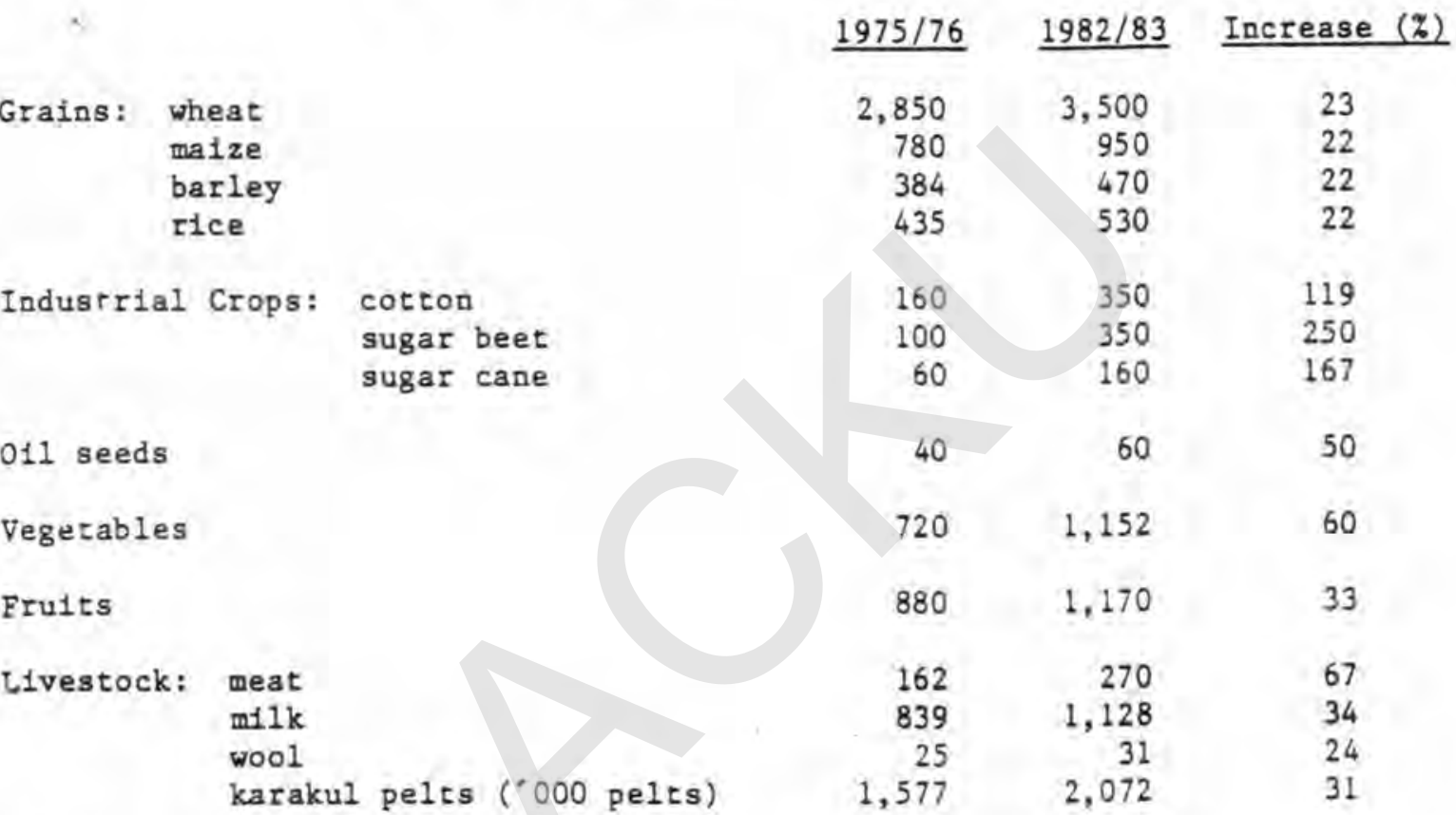

Within the Plan's increase in NNP of 6.2 percent annually, the agricultural sector's growth would be 4.65 percent.

4.32 In order to achieve this expansion in production the Plan provides the necessary additional physical inputs, notably an increase in the use of chemfcal fertilizers and 1mproved wheat and cotton seed for the whole irrigated area under these crops. The main capital investment would be to improve existing irrigation and bring new land under irrigation. A comprehensive range of measures to strengthen and improve agricultural services and institutions are also to be implemented. These include: doubling the number of extension workers; completing the Agricultural Research Institute and enlarging the research programs; greatly expanding the operations of AgBank which, 1n the last year of the PIan, will be making 181,000 loans totaling Af 2.1 b1111on; assisting the formation of agricultural and livestock cooperatives; and 
strengthening plant protection and animal health services. Other notable measures to promote agricultural production in the PIan are land reform and land taxation, improvements in administrative procedures, planning and programing, and policies relating to stabilization of producers' prices.

4.33 In total the Plan allocates Af 11.3 billion for agricultural development and Af 32 billion for irrigation development, equivalent to 6.5 percent and 18.2 percent respectively of the national budget. While this is a considerable reduction in agriculture and irrigation's share from 34.2 percent in the preceding seven years it is already apparent that there are likely to be difficulties both in securing the necessary resources and in the readiness of some of the projects.

4.34 The Plan target for agricultural growth is very ambitious. Few countries have sustained agricultural growth in the 4 to 5 percent range over long periods of time. While this ambition needs to be tempered by a realistic view of the constraints on project implementation, the overall outlook remains an optimistic one given Afghanistan's agriculcural potential in the longerterm.

4.35 Any assessment of the Plan targets must begin with irrigation. The Plan projects 397,000 ha to be irrigated by $1982 / 83$, of which 62,000 ha will be newly irrigated land while the remainder will be improvements in existing irrigation. Many of the irrigation projects are however at very early stages in the project cycle, and have not yet been prepared, nor have financial commitments been obtained for them. This applies to major projects such as Kokcha, Chasme Shefa, Kamal Khan and Seraj. Other projects are more advanced but even in these the Plan's implementation schedule appears optimistic in the light of past experience. It would seem appropriate to allow for a shortfall of about one-third in the irrigation target, though this is aot to argue that the projects proposed are poorly concelved. The preparation of a master plan for irrigation developwent is needed however to insure the optimum progress in relieving Afghanistan's most critical growth bottleneck. To be sure a number of studies of individual river basins are being undertaken, but there is a need to integrate these into a broad strategy for irrigation development.

4.36 The Plan projects fertilizer consumption to rise from about 70,000 tons in $1976 / 77$ to 368,000 tons in 1982/83. This is optimistic in the light of the likely shortfall in irrigation development, since fertilizer use is largely dependent on progress in this area. A target of 200,000 tons by the end of the Plan would represent a substantial achievement and is in line with past growth rates adjusted for additional irrigation facilities.

4.37 The adjusted irrigation and fertilizer targets, combined with an allowance for extension and institutional factors, can be translated into crop yields for the purpose of projecting likely output levels. The yield of dry land wheat is expected to increase by about 1 percent per annum from $1980 / 81$ onwards, because of improved seeds and better cultural practices as a consequence of the proposed integrated wheat development project. The yield in the irrigated area is expected to increase by about 2.7 percent per annum. This would represent an overall yield per ha 18 percent above the current 
level, as compared to the Plan figure of 23 percent. Similar modest shortfalls are also projected for cotton and other crops. The result of these yield and irrigated acreage projections is growth in net agricultural value added of roughly 3.9 percent per annum as compared to the Plan target of 4.65 percent. Table 19 embodles the assumptions outlined above in its projections of alternative production patterns of wheat and cotton over the Plan period.

\section{(1i) Food Security}

\subsection{The catastrophic effects of the $1970 / 71$ and $1971 / 72$ droughts have} highlighted the importance of national food security. In Afghanistan this is often interpreted as meaning food self-sufficlency, i.e. that the country should be able to meet its food needs without imports. Even this concept is susceptible to various interpretations. Food self-sufficiency could mean that food is stored in good years for re-sale in drought years, or it could mean that even in drought years there are adequate food supplies. It is this last meaning wich is of ten the wost popular as it implies very low prices in normal years. It makes little sense for Afghanistan to follow such a strategy however, and in any case it would be virtually impossible to sustain without a policy of price supports or scope for exporting. In either case it would be a very costly strategy in terms of the opportunities foregone for production of high-value cash crops. There is evidence that the Government is moving away from this extreme interpretation of food security.

4.39 In practice there are two reasonable alternative approaches to food security. The first lies in increasing domestic production of wheat to provide sufficient surplus in good years to be stored as reserves for release in drought years. The second means relying on either ad hoc 1mport arrangements when shortages arise or imports which are stored for distribution in lean years. Both solutions would require the Food Procurement Department (FPD) to buy surpluses, store quantities of $200,000-300,000$ tons and arrange for country-wide distribution in drought years. To-date the main function of the FPD has been to procure and supply wheat flour to government employees.

4.40 The choice between the alternative strategies of food self-sufficiency and food security through imports must be looked at from two points of view the national economy and the farmer. For the country as a whole, what is the difference between the two approaches? Obviously food self-sufficiency means that more land must be devoted to wheat production, In a trade-oriented strategy, some land is released for production of cash crops. In the calculation in Table 19 below, cotton is taken as representative of other cash crops. Two scenarios are worked out which demonstrate, in Part III of the Table, the advantage of following a trade-oriented strategy. Modest additional amounts of wheat would need to be imported, but they would be more than compensated by export earnings. During the next eight years, Afghanistan would earn $\$ 345$ million more under the second strategy than the first. This is obviously a very substantial sum. In addition, because of the heavy effective taxation of cotton the fiscal impact of this would be sizeable. Earnings frow wheat production could only be tapped by the fiscal system through direct taxes on farmers, or taxes on inpurs and services. These are unpopular and administratively cumbersome. 
Table 19: ALIERNATIVE SCEIARIOS FOR NGRICULTURAL DEVELOPIENT

\section{PART I: Wheat Self-Sufficiency}

Wheat

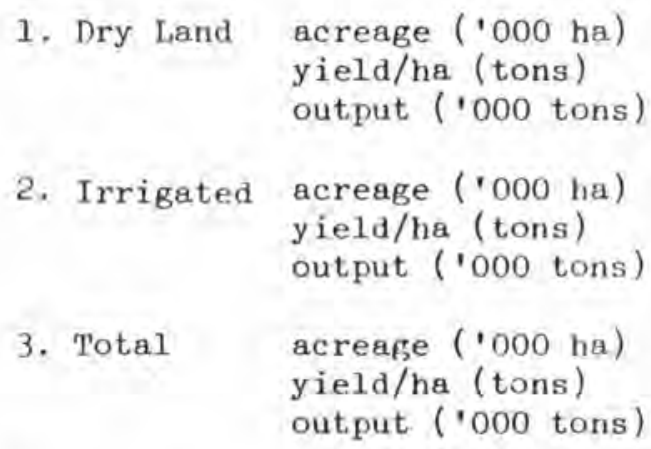

\begin{tabular}{|c|c|c|c|c|c|c|c|c|c|}
\hline $\begin{array}{c}1976 / \\
\quad 77 \\
\end{array}$ & $\begin{array}{c}1977 / \\
78 \\
\end{array}$ & $\begin{array}{c}1978 / \\
79 \\
\end{array}$ & $\begin{array}{r}1979 / \\
80 \\
\end{array}$ & $\begin{array}{c}1980 / \\
81 \\
\end{array}$ & $\begin{array}{c}1981 / \\
82 \\
\end{array}$ & $\begin{array}{r}15821 \\
83 \\
\end{array}$ & $\begin{array}{c}1983 / \\
84 \\
\end{array}$ & $\begin{array}{c}1984 / \\
85 \\
\end{array}$ & $\begin{array}{c}1935 / \\
86 \\
\end{array}$ \\
\hline $\begin{array}{c}892 \\
0.696 \\
621\end{array}$ & $\begin{array}{c}892 \\
0.570 \\
511\end{array}$ & $\begin{array}{c}892 \\
0.696 \\
621\end{array}$ & $\begin{array}{c}892 \\
0.696 \\
621\end{array}$ & $\begin{array}{c}883 \\
0.703 \\
621\end{array}$ & $\begin{array}{c}874 \\
0.710 \\
621\end{array}$ & $\begin{array}{c}866 \\
0.717 \\
621\end{array}$ & $\begin{array}{c}857 \\
0.724 \\
620\end{array}$ & $\begin{array}{c}848 \\
0.732 \\
621\end{array}$ & $\begin{array}{c}840 \\
0.739 \\
621\end{array}$ \\
\hline $\begin{array}{l}1458 \\
1.59 \\
2315\end{array}$ & $\begin{array}{l}1458 \\
1.62 \\
2358\end{array}$ & $\begin{array}{l}1490 \\
1.67 \\
2487\end{array}$ & $\begin{array}{l}1500 \\
1.71 \\
2566\end{array}$ & $\begin{array}{l}1494 \\
1.77 \\
2645\end{array}$ & $\begin{array}{l}1498 \\
1.82 \\
2726\end{array}$ & $\begin{array}{l}1503 \\
1.87 \\
2811\end{array}$ & $\begin{array}{l}1501 \\
1.93 \\
2897\end{array}$ & $\begin{array}{l}1522 \\
1.96 \\
2984\end{array}$ & $\begin{array}{l}1537 \\
2.00 \\
3074\end{array}$ \\
\hline $\begin{array}{l}2350 \\
1.21 \\
2959\end{array}$ & $\begin{array}{l}2350 \\
1.22 \\
2869\end{array}$ & $\begin{array}{l}2362 \\
1.33 \\
3108\end{array}$ & $\begin{array}{l}21.30 \\
1.34 \\
3187\end{array}$ & $\begin{array}{l}2434 \\
1.38 \\
3266\end{array}$ & $\begin{array}{r}2491 \\
1.39 \\
3347\end{array}$ & $\begin{array}{l}2462 \\
1.45 \\
3432\end{array}$ & $\begin{array}{l}2464 \\
1.50 \\
3517\end{array}$ & $\begin{array}{l}2477 \\
1.54 \\
3605\end{array}$ & $\begin{array}{l}2487 \\
1.58 \\
3695\end{array}$ \\
\hline 2959 & 3024 & 3108 & 3187 & 3266 & 3347 & 3432 & 3517 & 3605 & 3695 \\
\hline 23 & 145 & - & - & - & - & - & - & - & - \\
\hline $\begin{array}{r}115 \\
1.43 \\
164\end{array}$ & $\begin{array}{r}115 \\
1.49 \\
171\end{array}$ & $\begin{array}{r}91 \\
1.55 \\
141\end{array}$ & $\begin{array}{r}89 \\
1.59 \\
142\end{array}$ & $\begin{array}{r}102 \\
1.67 \\
170\end{array}$ & $\begin{array}{r}107 \\
1.73 \\
185\end{array}$ & $\begin{array}{r}109 \\
1.79 \\
195\end{array}$ & $\begin{array}{r}120 \\
1.86 \\
223\end{array}$ & $\begin{array}{r}107 \\
1.92 \\
205\end{array}$ & $\begin{array}{l}103 \\
2.0 \\
206\end{array}$ \\
\hline 1573 & 1573 & $15 L_{1}$ & 1589 & 1596 & 1605 & 1612 & 1621 & 1629 & 1640 \\
\hline 4.5 & 26.4 & - & - & - & - & - & - & - & - \\
\hline 68.1 & 72.6 & 49.9 & 49.1 & 62.8 & 70.7 & 75.5 & 91.1 & 72.6 & 64.3 \\
\hline
\end{tabular}

\begin{tabular}{|c|c|c|c|c|c|c|c|c|c|}
\hline $\begin{array}{c}19761 \\
77 \\
\end{array}$ & $\begin{array}{c}1977 / \\
78 \\
\end{array}$ & $\begin{array}{c}1978 / \\
79 \\
\end{array}$ & $\begin{array}{r}1979 / \\
80 \\
\end{array}$ & $\begin{array}{c}1980 / \\
81 \\
\end{array}$ & $\begin{array}{c}1981 / \\
82 \\
\end{array}$ & $\begin{array}{c}15821 \\
83 \\
\end{array}$ & $\begin{array}{c}1983 / \\
84 \\
\end{array}$ & $\begin{array}{c}1984 / \\
85 \\
\end{array}$ & $\begin{array}{c}1935 / \\
86 \\
\end{array}$ \\
\hline 892 & 892 & 892 & 892 & 883 & 874 & 866 & 857 & 848 & 840 \\
\hline $\begin{array}{c}0.696 \\
621\end{array}$ & $\begin{array}{c}0.570 \\
511\end{array}$ & $\begin{array}{c}0.696 \\
621\end{array}$ & $\begin{array}{c}0.696 \\
621\end{array}$ & $\begin{array}{c}0.703 \\
621\end{array}$ & $\begin{array}{c}0.710 \\
621\end{array}$ & $\begin{array}{c}0.717 \\
621\end{array}$ & $\begin{array}{c}0.724 \\
620\end{array}$ & $\begin{array}{c}0.732 \\
621\end{array}$ & $\begin{array}{c}0.739 \\
621\end{array}$ \\
\hline 1458 & 1458 & 1490 & 1500 & 1494 & 1498 & 1503 & 1501 & 1522 & 1537 \\
\hline 1.59 & 1.62 & 1.67 & 1.71 & 1.77 & 1.82 & 1.87 & 1.93 & 1.96 & 2.00 \\
\hline 2315 & 2358 & 2487 & 2566 & 2645 & 2726 & 2811 & 2897 & 2984 & 3074 \\
\hline 2350 & 2350 & 2362 & 21,30 & 2434 & 2491 & 2462 & 2464 & 2477 & 2487 \\
\hline 1.21 & 1.22 & 1.33 & 1.34 & 1.38 & 1.39 & 1.45 & 1.50 & 1.54 & 1.58 \\
\hline 2959 & 2869 & 3108 & 3187 & 3266 & 3347 & 3432 & 3517 & 3605 & 3695 \\
\hline 2959 & 3024 & 3108 & 3187 & 3266 & 3347 & 3432 & 3517 & 3605 & 3695 \\
\hline 23 & 145 & - & - & - & - & - & - & - & - \\
\hline 115 & 115 & 91 & 89 & 102 & 107 & 109 & 120 & 107 & 103 \\
\hline 1.43 & 1.49 & 1.55 & 1.59 & 1.67 & 1.73 & 1.79 & 1.86 & 1.92 & 2.0 \\
\hline 164 & 171 & 141 & 142 & 170 & 185 & 195 & 223 & 205 & 206 \\
\hline 1573 & 1573 & $15 L_{1}$ & 1589 & 1596 & 1605 & 1612 & 1621 & 1629 & 1640 \\
\hline 4.5 & 26.4 & - & - & - & - & - & - & - & - \\
\hline 68.1 & 72.6 & 49.9 & 49.1 & 62.8 & 70.7 & 75.5 & 91.1 & 72.6 & 64.3 \\
\hline
\end{tabular}
4. Demand
('000 tons)
5. Imports ('000 tons)

Cotton
6. Irrigated acreage ('000 ha) yield/ha (tons) output ( 1000 tons)

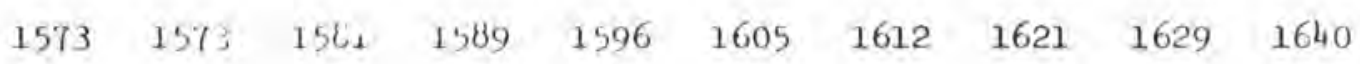

7. Total Irrigated Area under Wheat and Cotton ('000 ha)

8. Import Cost of Wheat (million US\$) 
PART II: Trade--Oriented Strategy

\section{Wheat}

$$
\begin{array}{ll}
\text { 10. Dry land } & \begin{array}{l}
\text { acreage ('000 ha) } \\
\text { yield/ha (tons) } \\
\text { output ('000 tons) }
\end{array} \\
\text { 11. Irrigated } & \begin{array}{l}
\text { acreage ('000 ha) } \\
\text { yield/ha (tons) } \\
\text { output ('000 tons) }
\end{array}
\end{array}
$$

12. Total

acreage ('000 tons) yield/ha (tons) output ('000 tons,

\section{Demand ('000 tons)}

14. Imports ('000 tons)

\section{Cotton}

15. Irrigated acreage ('000 ha) yield/ha (tons) outnut (' nnn tons)

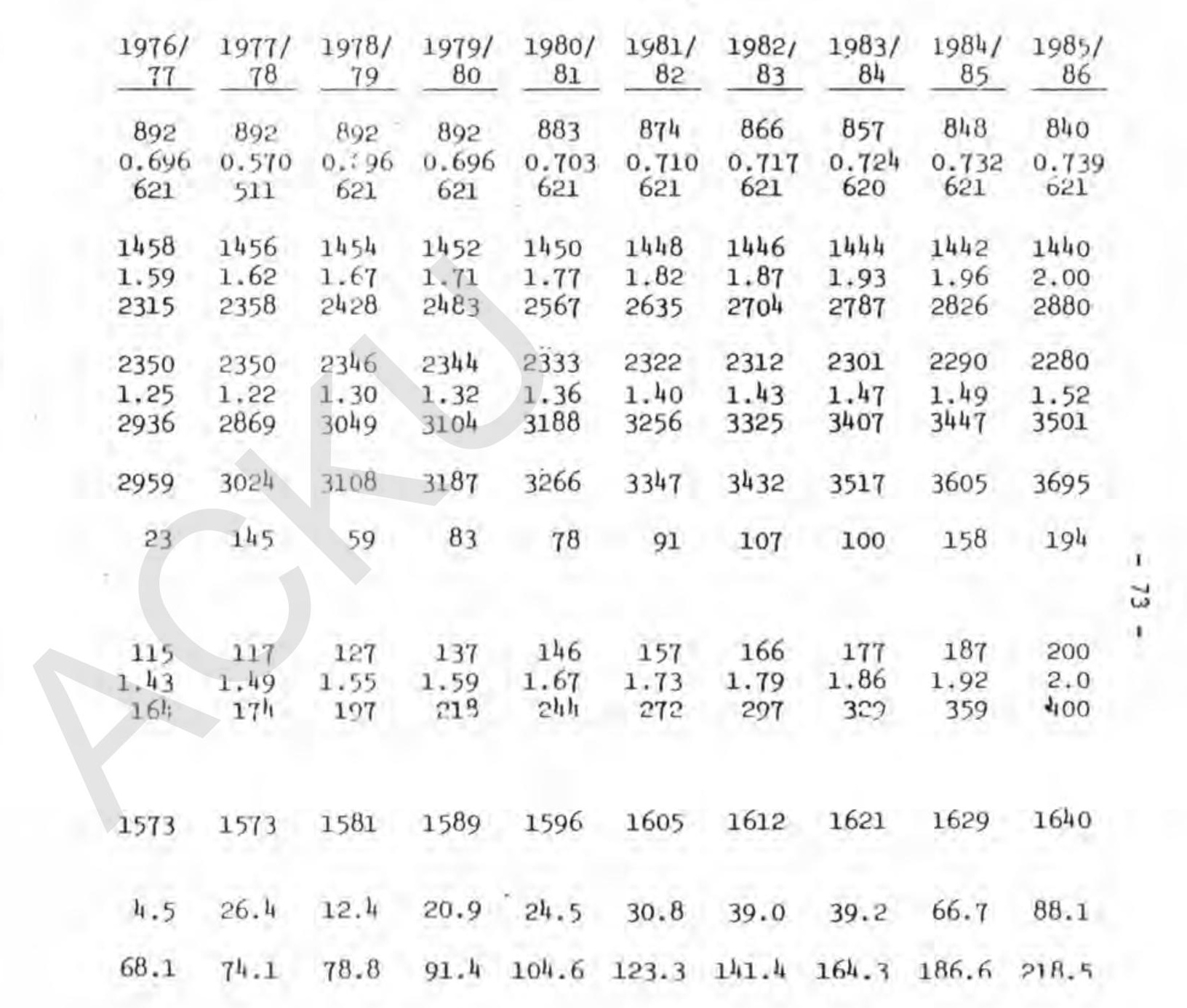

\section{Totals}

16. Total Irrigated Area under Wheat and Cotton ('000 ha)

17. Import Cost of Wheat

18. Export Earnings from Cotton 
Table 19: ALTERNATIVE SCENARIOS FOR AGRIGULTURAL DEVELOPMENT

PART III: The Strategies Compared

19. Net Import Cost of Wheat (II-I) (million US\$)

20. Net Export Earnings from Cotton (II-I) (million US\$)

21. Exchange Benefits from Strategy II (million US\$)

$$
\begin{array}{rrrrr}
1976 / & 1977 / & 1978 / & 1979 / & 1980 / \\
77 & 78 & 79 & 80 & 81 \\
\hline
\end{array}
$$$$
-
$$

12.4

20.9

22.7

1981/

82
1982/

83

1983/

$1984 /$

$1985 /$

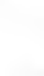

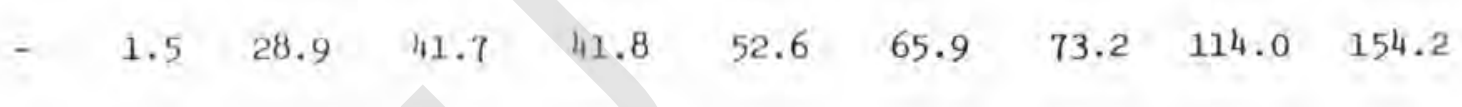

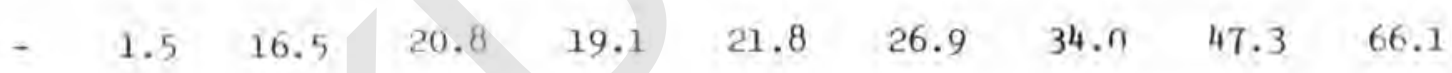

a/ Based on the IBRD price forecast for wheat (f,o.b. North America) over 1977 to 1985 (see IBRD Report No. $847 / 77$, June 1977 , pp. 28-29); the projected annual average rate of increase is about 14 percent. A 40 percent premium for transport costs, estimated on the basis of available data, has been assumed to obtain the c.i.f. Kabul equivalent.

b/ The average 1976/77 f.o.b. Kabul price was projected over 1977 to 1985 also according to the IBRD forecast (Ibid.); the projected annual rate of increase is about 4.8 percent. 
4.41 At current producer prices and world values (adding or deducting transport to and from Afghanistan for imports or exports respectively) the estimated gross values to the farmer and the economy per ha are:

$\begin{array}{llll}\text { wheat: } & \text { farmers } & \text { Af } 19,200 & \text { economy Af } 35,000 \\ \text { cotton: } & \text { farmers } & \text { Af } 30,000 & \text { economy Af } 65,000 \\ \text { sugar beet: } & \text { farmers } & \text { Af } 33,000 & \text { economy Af } 56,000\end{array}$

It is evident that farmers, even with high rates of effective taxation, have a substantial incentive to plant cotton or sugar beet. There are a number of other factors which also influence decisions on how much wheat, cotcon or sugar beet should be planted. At present, crop rotations are not very well esfablished in Afghanistan, and indeed in the absence of adequate research it 1s difficult to advise on optimum cropping patterns for different farming areas. Important factors include optimal use of avallable irrigation water (winter wheat has low water requirement), control of pests and diseases, weeds, and maintenance of soil fertility. There are very limited opportunities to double crop either sugar beet or cotton with wheat because of overlapping planting/harvesting times. Crop rotations have to be adapted to the various climatic zones which allow for example double cropping in places with a long growing season such as Jalalabad while only one crop is possible in Bamian which has a frost free season of only 140 days. Seasonal labor requirements and availability of casual labor, as well as the limitations of draft animals and possibilities of hiring tractor-drawn equipment, will also influence farmers decisions, since wheat needs less than half the labor per ha compared with cotton and sugar beet. Arother disincentive for cotton growers particularly in the Spinzar area has been the inefficient arrangements for accepting and paying farmers for their seed cotton.

4.42 A valid production strategy would seem to be to concentrate on raising wheat production in the more marginal irrigated land and in areas where cotton and sugar beet are not alternative crops. More intensive production practices in these areas would also optimize utilization of limited irrigation water which would be supplementary to rainfall. On the best lands, shifts to cotton or other crops should not be resisted. They are the way of Afghanistan's agricultural fucure.

4.43 A strategy for national food security also has to be consistent with the Govertment's policy to stabilise wheat prices pai-iculariy to prevent sharp upward movements in retail prices when crops are poor. FPD must therefore bulld up stocks through domestic purchases and imports. Early information on likely crop levels is an important component of efficient stock management. To improve crop forecasting, both interseasonal and particularly pre-harvest estimates, systematic collection and analyses of data on the various factors which affect crop output should be undertaken. Such an "early warning system"1/

1/ FAO reports W/K 4669 to the Government of Afghanistan on the "Development of an Early Walning System on Basic Food Supplies with Particular Reference to Crop Forecasting." Rome, January 1977. 
would enable the FPD to gear up to purchase surpluses from a good crop or import to build up stocks in advance of a poor crop. The FPD's plans for reserve stocks, 1mports and distribution would promote public confidence and reduce distuption from price fluctuations. A very tentative indication from the climatic and production records indicate that over a 10-year period four average crops may be expected with three above and three below average. Whichever crop production strategy is followed, the efficient operation of the FPD vill be essential to smooth out year-to-year price and supply fluctuations.

\section{(11i) Increasing Agricultural Export Earnings}

4.44 Agriculture can make a greater contribution to export earnings in two ways: through raising the quantity and quality of primary exports - cotton, meat, karakul, fruits, nuts, vegetables, etc. and by increasing the supply of products with large potential local added value through industrial manufacture and handicrafts. Import substitution, notably through increasing sugar beet production, will similarly benefit the balance of payments. As argued above, ralsing farmers' incomes and achieving optimal resource use argue for priority for high value export crops - cotton, fruits and vegetables - over self-sufficiency in wheat. Cotton exports can undoubtedly be increased fairly rapidly, say 10 percent annually, to double the export tonnage by the end of the Plan. This will obviously call for a comprehensive program to ensure that essential inputs are available and farmers are encouraged to use them. This expansion also calls for re-equipping ginneries and increasing the country's ginning capacity, with associated development of the oil seeds processing industries.

4.45 There have been increases of about 9 percent per annum in the volume of fresh and dried fruits and nuts exported between 1968/69 and $1975 / 76$. Although the Plan forecasts a continuation of the 9 percent growth rate in exports of all fruits this may prove over optimistic. $1 /$ A realistic estimate, allowing for 2 percent annual increase in per capita domestic consumption of fruit, (domestic per capita consumption has remained static for several years while all increases in production have gone to export) indicates there is unlikely to be any increase in availability for export and fruit exports can be expected to level out. The possibilities of upgrading the quality of fruits for export to increase untt value will have to be explored. In contrast, vegetables which have been banned for export for the past five years could well provide a substantial volume if the ban were lifted. Some progress has been made in this regard with the establishment of the Afghan Vegetable Export Corporation which has been given loosely defined export quotas. Further liberalization could be undertaken, in conjunction with taxes on vegetable exports, to prevent disruption of supplies on the local market,

4.46 A modest increase in export earnings from livestock products may be achieved when the Herat abattoir goes on stream towards the end of 1977 . This

If See World Bank Report No. 1324-AF, op. cit. 
will have the capacity to handle half a million lambs each year. The Plan target of 6,000 tons meat exports per annum, equivalent on average to about 250,000 lambs appears well within the capacity of the Herat abattolr. Only limited increases in exports of other traditional products such as karakul pelts, casings, wool, hides and skins are expected. Local industry and handictafts will be utilizing more of these products.

4.47 Afghanistan should give particular attention to measures which will raise the quality of agricultural export products notably through better cotton varieties, processing and packaging of fruits and vegetables, and wool scouring. These measures, supported by export grading controls operated by such agencies as the Karakul Institute, Herat abattoir, cotton ginneries, and by the proposed Fruits and Nuts Irade Regulatory Commission and Vegetable Export Corporation, would increase unit value and could result in additional employment in the smaller market towns where such opportunities are very limited at preseut.

\section{Policy Measures and Programs}

\section{(i) Human Resources - The Farmers}

4.48 In many respects the most neglected, though by far the most important, element in the agricultural scene are the farmers. There are probably at least one million full-time farmers most of whom are illiterate. Because of inadequate rural schools, the majority of the next generation of farmers will also be illiterate. Fortunately farming competence is not dependent on a high standard of education, though this should not be regarded as an excuse for not improving rural school facilities as quickly as possible. Farmers need training in improved production practices and this is likely to be most effective when related to specific techniques to promote the main crops. In addition to learning new husbandry practices, an increasing number of farmers must understand the basic principles of farm business management in order to prepare simple farm plans as the basis for obtaining loans from AgBank. Special attention should be glven to preparing the next generation of farmers, and practical tzaining courses could be provided for young farmers. These have been successful in many countries. Field days for farmers to visit the research stations might be popularized in Afghanistan. Training of women for more skilled farming operations and increased employment of women may be given itpetus if a Lural labor shortage results from Afghan workers finding more remunerative employment outstde the country.

4.49 Although they are individualistic and suspicious, Afghan farmers have a tradition of cooperating for a common benefit as seen 1 n the repair of irrigation systems, and, in some areas where irrigation water is inadequate to supply all individual farmers' need, land is even farmed cooperatively. Agricultural cooperatives are institutions which could build on this tradition while providing a forum for the new ideas and initiatives which are needed in rural Afghanistan. Following the promulgation in 1974 of the Cooperative Law, the cooperative movement has grown rapidly and by mid-1977 
there were 102 societies with 9,095 members in 12 provinces. Only two cooperative unions have been formed. To motivate and involve farmers in all aspects of policies and measures to improve agriculture, it is desirable that farmers' representatives should be appointed as members of Management Boards and Comittees of the various parastatal agencies and development authorities. With the establishment of Cooperative uninns these could provide farmer representation.

\section{(ii) Farming Structure}

4.50 The 1967 Census of Agriculture gives an average size of farm holdings of $3.5 \mathrm{ha}$. Over 70 percent of holdings are less than this size, while a substantial proportion of the total area is owned by a small number of large landowners. The larger holdings are either rented to other farmers, sharecropped or farwed with hired labor. As explained in para, 3.48, hired laborers are frequently paid a percentage of the crop instead of cash wages. The previous low cost, ready avallability and immobility of rural workers has favored labor intensive systems with payment in kind. This practice is followed even by quite small farmers whose families are of sufficient size to meet all the labor needs of the holding. The size and nature of farm holdings varies widely between different parts of the country. In the Khanabad Irrigation Project the average size of holdings is 5 ha and nearly 80 percent of farms are owner-operated. In the Helmand Valley sharecropping predominates. In the irrigated areas of the provinces of Ghazni and Wardak there appear to be relatively few large land holdings and indeed the small average size of holdings is a widespread problem. For settlenent on new irrigation schemes or where irrigated land is redistributed under the land reform program, holdings of $2.0-2.5$ ha have been allocated by the Government and these may not be subdivided.

4.51 Current agriculture development projects give emphasis to the planning and financing of viable small intensive farm units. The model units for which detailed farm plans have been prepared are representative of the form of improvement which could be applied to the great majority of holdings to be found in the different regions of Afghanistan. A 2 ha irrigited holding, intensively farmed with well managed irrigation water, good seeds and correct use of chemical fertilizers, can provide a net family annual income of about Af 35,000 . This would be derived from a rotation of wheat, cotton, maize and alfalfa/clover, but does not include the value of home-consumed vegeta. les or milk, Holdings of 2 to 4 ha of irrigable land are rather typical of the old established irrigated systems ranging from the Kabul Valley to Baghlan-Kunduz and Herat, with the high value cotton crop which can be included in the rotations in the north and west being substituted by grapes in the Kabul basin. Other farm models include larger holdings with mixed livestock and cash crops. Within this group a 10 ha farm at Herat for example, after development could realize additional net income of Af 142,000 annually from wheat, cotton, and sheep products.

4.52 Important features of farm plans in Afghanistan are that they should be based on optimal use of farm family labor and as far as possible be within the capacity of avallable animal power. Under the land reform law frrigated 
holdings will be restricted to a maximum size of 20 ha ( 30 ha if single crop Irrigation and 40 ha dry land farming). Holdings above 5 ha of fully 1rrigated land wll have to use labor additlonal to the farmer's family. The larger farmers are likely to favor tractors to cope with the extra work of seedbed preparation and planting. Tractors are useful in raising labor productivity in larger farms and coping with peak farm operations narticularly if the rural labor supply is inadequate, or if heavy cultivation is needed to break soll pans etc. In the long term interests of Afghanistan's agriculture, however tractors should be treated as supplementary to and not as replacement for animal power on the farm. An important reason for this is the role of forage crops together with the use of animal manure in building up and maintaining soll fertility under conditions of intensive irrigated cropping with high use of chemical fertilizer, cannot be overemphasized. Another obvious reason for favouring the use of oxen is the small size of fields separated by water channels which makes access by tractors very difficult. However, tractor use is subsidized through easy, cheap, credit provided by AgBank for purchase and Afghanistan's relatively low priced fuel.

4.53 Implementing the concept of viable family farm untts will require enforcement of the Land Reform Law, together with improvements in land tenure and water rights. It is unfortunate that the Cadastral Survey and Land Reg1stration which are the essential bases for land reform have made poor progress and appear to be discredited in some circles. The procedure now being enforced for the collection of the graduated land tax requires landowners to register their holdings and is regarded by the Government as complementary to the Cadastral Survey. The reliability of declared size and location of holdings is very questionable however, as a landowner would be reluctant to declare ownership of more than 100 jeribs which would treble his tax assessment and the Government is relying on this provision to secure accurate declarations.

4.54 At the present rate of progress, the Cadastral survey would require about 20 years more to complete. Its existing methods, apart from being slow, leave much to be desired in terms of accuracy. Nor do they confnrm to any overall system of map control. The problem would be solved by Aerfal survey and production of orthophoto plans. I/ Orthophoto plans could be produced in much less time than required for a ground survey and at comparable cost. Included in a proposed rural development project for Ghazni-Wardak is a component for an Aerial Survey of the project area, about 120,000 ha of arable land, at an estimated cost of $\$ 250,000$. This inftial project would have the dual purpose of demonstrating the efficiency of the method and training a nucleus of Afghan staff who could apply the method to complete the cadastral survey of. the whole country.

\section{(11i) Irrigation and Crop Production}

4.55 Attitudes to water in Afghanistan need to be fundamentally changed. It is remarkable that, in a country where human intervention is so essential in water conservation, storage, distribution and ut1lization, so little concern appears to be felt for getting maximum output from every 33 used or,

1/ FAO/World Bank Report 1/77 AFS 11. Annex IX. 
indeed, for knowing exactly how much water is avallable. A number of studies and surveys of varying quality have been carried out for some of the river systems or parts of them. It is however quite impossible to get a clear overall view of the country's water resources and potential for 1rrigation development.

4.56 The complete schedule of irrigation projects included in the present Plan relates to a total area of potential 1rrigation of 888,000 ha. of this total. 90,000 ha have already been developed and during the Plan a further 396,700 ha is proposed to be improved and developed (including 62,000 ha of new land) leaving a carryover of 401,000 ha. However, this is only about one quarter of the estimated total 1rrigated land. The generally quoted figure for 1rrigated cropped land is $2,500,000 \mathrm{ha}$, with about one quarter fallow making a total of $3,300,000 \mathrm{ha} .1 /$ If water were avallable (through more scorage, less wastage and more efficient use) the nearly one million ha now fallowed could be irrigated and cropped. Several more million ha of new land are suitable for development and irrigated cropping if water supplies were sufficlent. Given the absolute limfts imposed by avallability of irrigation water, the Plan rightly concentrates on Improving water supply and distribution in existing irrigation systems.

4.57 In view of the overriding 1mportance of irrigated agriculture 1t would be timely to undertake a critical evaluation of the current situation and ongoing project.. It is therefore strongly recommended that a survey should be undertaken which would also produce a national inventory of the irrigation structures, land areas irrigated and current cropping patterns. This would be invaluable for future planning, both for the agricultural sector and for formulating regional development programs.

4.58 To give greater impetus to national water development, responsibility for this activity was separated from the Minlstry of Agriculture in 1974 and given to the Water and Power Authority which has since been raised to ministry status. While it appears logical to relieve the Ministry of Agriculture of major engineering tasks it is very questionable whether another ministry should have on-farm responsibility for water use and consideration should be given to returaing this function to the Agriculture Ministry. While more appropriate administrative placement will help to provide a better focus on on-farm water use, it is secondary however to the need to train and employ adequate professional staff to carry out this function.

4.59 Reviews of progress in irrigation development indicate a number of problem areas. There are long delays in project implementation and the realization of the full benefits from such large investments. These costly

1/ It is somewhat difficult to reconcile the various estimates of irrigated land. The Ministry of Agriculture has published a figure of $3,884,000$ ha, Another estimate shown in the Asian Development Bank's Sectoral Planning Study of Afghan Agriculture is only 2,584,000 ha, The figure in the text above is consistent with the estimates of yield and output, however. 
delays could be avoided by improved planning and simplified administrative procedures. The need to integrate small scale irrigation works with ongoing or proposed major works, demonstrates the importance of preparing comprehensive river basin water development plans for the major rivers. Progress has been made in this respect for the Hari Rud, Farah Rud and northern rivers and in the current Plan, Canadian assistance will be obtained to prepare a master plan for the Kabul river. Water resources, including groundwater, studies and surveys to prefeasibility, feasibility and master plan stages are expected to be completed during the first three years of the Plan.

4.60 Progress of swall scale irrigation improvement has been disappointing for a number of reasons, Unless major works to control river flows are carried out, small scale works, such as the replacement of temporary diversions by permanent structures, may have little value. A fairly high level of engineering skill is needed to design even small works. Financing such works has presented difficulties because traditional water rights, which allow unlimited water use by upstream farmers, would result in an inequitable distribution of benefits. As a result it is difficult to levy charges to recover cost on an equitable basis. Even more importantly, the system results in inefficient water use as water is practically a free good to those upstream. Obviously a system of water charges has a role to play both in terms of equity and efficiency. A study is currently being undertaken to develop a system of water charges to allow for cost recovery on irrigation projects.

4.61 Considerable interest in groundwater development was stimulated by the droughts of 1970 and 1971 and AgBank's readiness to provide credit for the purchase of pump sets. The main interest was in pumping from shallow wells, as the risks and high operating costs of tubewells make them unatrractive for private development. With adequate rain in subsequent years, interest has tended to subside. Future development will require more information on groundwater resources but prima facie it would seem that efficient diesel engines pumping from shallow wells to serve organized groups of small farmers should provide an economic replacement for karezes,

4.62 Operation and maintenance of irrigation projects has been inadequate in the past but this deficlency has been recognized and larger resources have been allocated in the Plan. The Ministry of Water and Power has only 300 professionally qualifled Afghan engineers but the country's acute shortage of skilled manpower for irrigation construction and waintenance should be overcome after $4-5$ years as increasing numbers are graduated (though these young engineers must be given the opportunity to acquire adequate professional experience before being given primary responsibility). Notable advances in the civil engineering sphere can be seen in the establishment of two indigenous companies (government owned) the Helmand Construction Corporation which has won an Af 317 million contract for the Khanabad Irrigation Project and Water and Power Consultants, Afghanistan. Both companies can provide better conditlons of employment for Afghan staff than normal civil service employment and can therefore atrract well-qualified engineers.

4.63 In the longer term, as water storage and distribution works are completed, the scope for increasing crop output/water input ratios will depend on improving the efficiency of delivery of water to the fields and on improving 
crop-water utilization through better husbandry practices ant rotations. Research in these two areas should be initiated without delay by the concerned ministries. As Afghanistan has the good fortune to have huge supplies of 1 imestone and coal with which to produce cement this offers the prospect in the long term of lining irrigation distribution systems for delivery at the field. To enable the amount of water supplied to farms to be measured accurately it is proposed that one of the secondary canals of about one $m 3$ should be fully lined with gauges metering water delivered to each farm outlet. Records of the area irrigated, varleties of crops, quantity of water received etc. would provide the essential basic data for establishing minimum and optimal cropwater needs. An important feature of such a pilot metering distribution system is that it could also provide the basis for more equitable water rights with a fair share of water reaching the end of the canal. Autumn sown wheat, clover and a number of vegetables require only about half as much irrigation water as summer crops - cotton, sugarbeet and rice, though where summer irrigation water is adequate, these higher value crops give better economic returns. Cropping patterns and rotations should therefore be developed which will optimize crop output in relation to water availability.

\section{(iv) Livestock Production and Pasture Improvement}

4.64 The present low productivity of the flocks must be raised if the viability of the nomadic system is to be maintained and improved living standards are to be offered to the many people whose livelihood depends on their sheep and goats. This must involve a mure efficient management system which will ensure continuing and effective utilization of the extensive pasture resources. National programs should be mounted to strengthen veterinary diagnostic and clinical services, provide more vaccine for major campaigns, and train professional staff. The Kcrakul Institute is functioning effectively in regulating and improving export marketing of pelts, though there may be scope for the Institute and the Ministry of Agriculture to collaborate more actively in breed improvemert programs. Nomadic flocks are particularly vulnerable to unfavourable weather which causes marked cycles in sheep production. In good years when feed supply is relatively high, flock numbers build up until nutrition is inadequate and/or summer water avallabiltty becomes a limitation causing reduced lambing and highet mortality.

4.65 The nomadic pastoral system suffers from three major constraints, though to a lesser degtec they affect sedentary flocks as well. First and foremost shortage of feed throughout the year, but particularly in winter, limits the productivity of nomadic and semi-nomadic sheep and goats which have to rely mainly on the estimated 40 million ba of rangeland. Secondly, diseases considerably reduce productivity, and mortality rates are high, especially among young animals. Veterinaty services are inadequate or nonexistent in spite of UNDP/FAO and Russian technical assistance to establish clinical and diagnostic facilities and vaccine production. The third problem area is the livestock marketing system which is poorly developed with most animals being purchased and trekked to consumption centers through a chain of dealers and butchers. Supply of animals to main markets is very seasonal with peaks in late spring and late autumn and troughs in late winter and summer. Market prices fluctuate accordingly. No premium is paid for quality meat 
though the fat tall or fat rump commands a premium over mutton in Afghanistan. It should be noted however that for the past few years, with flockowners building up numbers after the drought and therefore reducing the avallability for slaughter and with the high prices ruling in neighboring Iran for fresh mutton, there has been a fairly active market for meat. Retall prices for meat in Kabul have almost doubled while cereal prices have been almost stationary.

4.66 What may well prove to be the pilot stage in a national program for livestock development and pasture improvement is the establishment of the Herat Livestock Development Company (HLDC). HLDC was set up in 1973 with responsibility for:

(a) On-farm development of about 1,200 farms to improve 1rrigation from groundwater, obtain breeding stock and produce alfalfa.

(b) Design and construction of a modern slaughterhouse with daily capacity of 3,000 head of sheep at full operation.

(c) Establishment of an Experimental Range Improvement Center.

(d) Provision of extension services to farmers, range research and management of the slaughterhouse.

The 1mmediate objective was to provide an export market for flock owners in the Herat area via a new slaughterhouse and export of chilled mutton. Longer term and more fundamental objectives were to establish an agency and system for 1mproving mixed farming husbandry systems and develop practical techniques for range management.

4.67 In the future 1t is proposed to extend HLDC's responsibilities to cover pastoral livestock development over the whole of Herat, Badghis and Parah provinces and the western two thirds of Ghor province. In this area of some $100,000 \mathrm{~km} 2$ there are about 144,000 famll1es - a m1111on persons w1th 2 million sheep and goats. Extension of HLDC's operations w11 inckude:

(a) Establ1shment of about 14 Sheep Improvement Centres; 7 each in winter and sumer grazing areas, which would serve as bases for the provision of field services to livestock owners.

(b) Provision of effective animal health services for all sheep and goats in the area.

(c) On-farm development (w1th loans from AgBank) for 50 individual farmers with holdings of around $10 \mathrm{ha}$ each, 50 cooperative groups of 14 small farmers having holdings of about 3 ha each and setrlement of about 25 nomadic groups of about 12 families each. 
(d) Expansion of the Experimental Range Improvement Center by establishing fleld stations in the highland summer grazing area and in the wintering area.

HLDC will also set up a unit to construct wells and farm access roads.

4.68 Good progress has been made in establishing HLDC as the chosen instrument for implementing development in this important area. By March 1977 credit had been provided to 569 livestock owners including 275 long term loans for Af 19.88 mflilion. Good contacts have been established with flock owners through extension work and surveys. The slaughterhouse has been completed and was ready for operation in late 1977. When the second phase of HLDC's program is fully operational, and initial experience has been gained in slaughter and export of chilled mutton an indepth evaluation of this program should be undertaken. Particular attention should be givea to techntcal aspects relating to raising productivity of winter and summer ranges, 1.e. the work of the Experimental Range Improvement Center. Based on the results of this review $1 t$ would be possible to formulate the next phase of the program which could include the progressive development of a complete range management system within HLDC's project area and the extension of the program both to the Helmand Valley in the south and to the northern provinces.

4.69 The cattle population of Afghanistan, estimated at 3.6 million head (including about 1 million each of work oxen and cows), reprcsents a valuable asset and its potential may not be fully appreciated. Cattle are maintained in close association with irrigated farming. They provide the major source of draft power and dairy products for villages, while their dung is used for manuring fields or for fuel where wood is scarce. Productivity of the indigenous breeds is low due to inadequate nutrition. The national average for milk lactations is only $400-450 \mathrm{~kg}$, though yields in the Baghlan area where farmers supply a Swlss-managed dairy plant, are reported to be $1,200-1,500 \mathrm{~kg}$. Oxen, which are relatively well fed for the heavy cultivation season, work well. Exotic breeds, mainly Brown Swiss and Holstein have been introduced and have adapted satisfactorily. The pilot dairy development undertaken in the Baghlan area with Swiss technical assistance has shown there are good prospects for establishing commercial milk production by small farmers for collection to supply town dairy plants. This could certainly contribute a useful additional income to small farmers and could fit very well in integrated rural development programmes such as is proposed for Ghazni-Wardak where small farmers would be assisted to own a few cows and their milk would be collected by a dairy plant in Kabul. $1 /$

1) An FAO mission under the International Scheme for Coordination of Dairy Development has prepared a plan for developing the Kabul dairy plant and the expansion of milk production to supply it. 
4.70 As in many developing countries, the growth of towns and rising urban incomes is causing a keen demand for poultry meat. Earlier attempts to establish large scale commercial broller and layer poultry units in the Kabul area have not been very successful due in part to the absence of an organized supply of balanced poultry feed. Currently another attempt at a large poultry project is being made through setting up a state enterprise with Bulgarlan assistance. When this undertaking is established consideration could be given to expanding production through associated village farmers or cooperatives.

4.71 To support both the poultry and dairy development programmes a commercial animal feed 1ndustry needs to be established which would utilize the considerable quantities of feed raw materials from the oll seed, sugar and cereal milling factorles. Studies for establishing an animal feed industry have indicated the feasibilfty of setting up a feed plant at Baghlan.l/ This plant would utilize local raw materials including dried beet pulp, molasses and cotton meal. The infial volume of production, which would be limited by the availability of beet pulp and molasses, would be about 20,000 tons though this could be doubled when the new sugar factory reaches full capacity.

\section{(v) Incentives and Investment}

4.72 Afghan farmers have demonstrated their responsiveness to changes in relative prices of different crops. The rise in the producer price of cotton from Af $12.6 / \mathrm{kg}$ in $1973 / 74$ to Af $15 / \mathrm{kg}$ in $1974 / 75$, has led to a 50 percent increase in output. Compared with the present officlal support price for wheat of Af $6.5 / \mathrm{kg}$, cotton production is clearly more attractive. A sound pricing policy will have to ensure that cotton and sugar beet are the most attractive crops in areas convenlent to processing facilities; but at the same time the price for wheat must be kept high enough to encourage farmers to use 1nputs. As a basis for sound pricing policies it is essential that systematic cost of production surveys covering the major crops should be undertaken each year.

4.73 Investment in agriculture over the past three decades (and for centuries previously) has meant irrigation. Traditional irrigation works were highly labor intensive both in the original construction and their subsequent maintenance. These works were designed to provide immedlate benefit (however inefficient in water use) through permitting land to be farmed. They were carried out within the current resources of the people who would benefit and Involved no external investment or debt. More recent irrigation schemes have 1nvolved large amounts of external finance, complicated englneering works and long intervals before realizing full benefits. A comparison of these two models of irrigation development suggests that priority should be given to

If (1) Report on the Proposed Feed Mill at Baghlan by U.K. ODA. 1973 (11) Provisional Report on the Feasibility of an Animal Feed Industry in the Region of Baghlan, by Swiss technical Cooperation 1977. 
irrigation works which will provide quicker returns - improvements to existing water distribution systems and smaller works. At the same time, farmers should make greater contributions to these programs (as they did in earlier times). This could take the form of a capital charge un land in the case of improvement to an existing system (to be liquidated over a period of years), or rent to be pald by new settlers on irrigated land. In smaller projects farmers could contribute by providing labor, local construction materials, and local animal transport. In all types of development, farmers should undertake land development, clearing, levelling, terracing, and fleld water distribution. In the farm models developed in projects for World Bank assistance it is clear that sufficient savings would be generated to allow farmers to meet operation and maintenance costs and even repay irrigation investment costs within a fairly short time span.

4.74 The Plan proposes to invest Af 32 billion in irrigation which will allow 396,000 ha to be developed including 62,000 ha of new land. The balance consists of improving existing irrigation schemes. This amounts to about $\$ 1,600$ per ha but covers only the cost of providing reasonably effective irrigation systems. In future, further phases of improvement will be required particularly in realignment, and perhaps lining, of distribution systems and rationalisation of fields and farm holdings. Projecting forwdrd to the end of the century, if the same rate of irrigation as envisaged in the Plan is maintained, a further 1 million ha of irrigated land would be improved at a cost of $\$ 1,6$ billion (in $1976 / 77$ prices). This would be a rate of 2 percent of total irrigated land annually. By the year 2000 half of the irrigated land would still be unimproved.

4.75 Investment requirements for livestock and pasture improvement are far more difficult to estimate. One can generalize from HLDC's program to provide bases for nomadic groups of 12 families at an investment cost of $\$ 42,000$ each. Assuming each unit contains an average of 1,400 head of sheep, about 120,000 nowadic families, if settled in 10,000 groups, would require an investment of $\$ 426$ million. In addition substantial investment will be required to improve rangelands through stock watering points, grazing management and improvement of pastures. The next phase of the HLDC project will require a vastly increased rate of development and investment to achieve any real impact in modernizing the nomadic system.

4.76 Off-farm investment is required for the progressive improvement of infrastructure to support farm development. Construction and improvement of farm-to-market roads deserve high priority, though the Plan makes little provision for these minor roads improvements. Primary marketing facflities and storage for produce, notably reserve stocks of wheat, will also call for large investments to provide inter alfa for more efficient and hygienic facilities for food products marketing including wholesale and retail markets and shops. Agricultural processing industrtes are given a budget of Af 13.8 billion. This figure includes major investments in expanding urea production by 300,000 tons and cotron ginning capacity by 175,000 tons, as well as flour mills, abattolrs, sugar beet factories, and fruit processing plants, 
(vi) Institutions and Services

4.77 Coordination and management of the activities of all the Government institutions and services which are concerned with agriculture is the primary responsibility of the Ministry of Agriculture. There are however some notable exceptions including on-farm irrigation development (WAPM) and the agricultural activities of BAVA and RDD. The Ministry has a conventional structure, with headquarters departments representing the different subsectors and corresponding departments in the provinces. Having shed responsibillty for supplying inputs to farmers to AgBank, AFC and ASC, the Ministry is in a position to concentrate on its major functions of policy making and planning, extension, agricultural research and the provision of national plant protection and veterinary services.

4.78 Some strengthening and reorientation of agricultural planning is needed. At all stages of programming and project analysis from 1nitlal conception through to feasibility studies and implementation the Minlstry of Agriculture's technical departments should play a much bigger role. The role of the Ministry's Planning Department should be primarily that of coordinating multidisciplinary projects and providing the specialist economic participation, To improve the Ministry's overall competence to elaborace policy measures and formulate projects, the Planning Department should undertake an annual sample survey of the sector and cost of production studies. These surveys can be designed now, and methodology tested for implementation immediately following the 1978 national population census and the 1980 census of agriculture.

4.79 The progressive strengthening of the Ministry of Agriculture's field staff is needed. It is essential to upgrade the technical and practical compecence of agricultural extension staff and particularly the extension supervisors who must be capable of advising farmers on efficlent farm planning and management. There should be regular inspection visits by sentor officials and specialists to the provincial directoraces and research statons. There is clearly room for more effective inter-departmental coordination in provincial agricultural offices particularly through closer liaison between extension staff and research stations. A review of the whole agricultural education and training system and facilities should be undertaken. 1 / In undertaking this review the focus should be on the ultimate objective of upgrading technical skills and management at the farm level and including the need to provide tulities for training farmers and even more importancly, for training their sons.

4.80 Agricultural Research is the weakest link in the chain of institutions and services and top priority should be given to providing adequate staff and facilities for research. Primary responsibility for research lies in the Ministry of Agriculture which has 10 reglonal stations employing about 120 professional staff. Until the function was partly taken over by ASC much of the research stations' effort and land was devoted to raising foundation

1/ A national extension study will be carried out as part of the second phase of the Khanabad Irrigation project which will cover part of this proposal. 
seed and root tree stocks. Research programs have concentrated on selection of higher yielding varieties, response to fertilizers, effectiveness of chemical treatments (insecticides and pesticides), seeding rates, and planting dates. Initially research was directed at raising yields of irrigated wheat, though recently more attention has been paid to cotton (notably with French assistance), rice, maize, sunflower, sugar beet and vegetables. Although there is now a competent cadre of keen, well trained, professional research workers, due to critical shortages of budget and equipment, lack of overall direction, insufficient continuity of specific programs and the high turnover and transfer of key staff, achlevements have been very disappointing.

4.81 This situation cannot be allowed to persist. New impetus and a higher statys for agricultural research might be achieved if the proposal to establish a National Agricultural Research Institute is implemented. While specific research programs e.g. for cotton varieties, dry land wheat etc. should be continued, coordination and direction on a national basis rather than by commodity institutes is essential to promote effective farming systems and rotations. Major long-term programs should be assigned to 2 or 3 selected Iesearch stations while short-term crop improvement programs should be designed for each research station for those crops which are important in the area they cover. In addition to specific crop research programs, a major effort should be directed to research on all aspects of crop-soll-water relationships in order to identify practices which wil, achieve maximum water use efficiency. Crop rotations should also be studied in the long-term research programs, as already a serious problem of weed control has appeared, which might be tackled most effectively through a rotation which includes legume Eorage crops. A thorough appraisal of Afghanistan's research needs, and the cormulation of a program to meet them, is a matter of urgency.

4.82 The faculty of Agriculture of Kabul University also undertakes limited agricultural research. Although the faculty's facilities are very limited, its highly qualified staff could certainly be used part time to support programs at the research stations.

4.83 Plant protection resources have rightly given priority to combatting locust attacks. About 3.5 million jeribs of land in the north, northwest, and cencral areas will be brought under protective measures for locust concrol, during the Plan period. Effective chemical control of fruit pescs has also been introduced and the service should be built up progressively. A diagnostic laboratory for this purpose is envisaged with UNDP finance. Veterinary services have given priority to vaccine production and campaigns to control major animal diseases. Some success can be claimed in the nonappearance of rinderpest for the past three years. Efforts are underway to establish regional diagnostic centers and laboratories. Central clinics are planned to increase from 17 in 1975 to 27 in 1983, while vaccine production is planned to treble during the same period. A crucial constraint is the shortage of professionally qualified Afghan veterinarians for posting to the regional animal health centers, provincial services, and HLDC. Currently, Afghanistan has less than 500 veterinary technicians and only a few of them have anything more than rudimentary technical skills. The problem will be solved if an adequate number of high caliber entrants come forward to atcend che five-year courses in Animal Production and Health in the Animal Science 
Faculty at Rabul University. At present there are only 29 students attending the $4 \mathrm{th}$ year of these courses though, with 315 in $1 \mathrm{st}$, 2nd and $3 \mathrm{rd}$ years, the plan target of 100 entrants a year is being achieved. Sound practical postgraduate experience of animal disease problems in Afghanistan will be provided in the regional centers and with HLDC.

4.84 Good progress has been made to equip Afghanistan with institutions capable of delivering to farmers the main 1nputs needed to intensify irrigated cropping and expand output. The Agricultural Development Bank (AgBank) was established in 1965 and is entirely state owned. In the interim it has been transformed into an effective agricultural credit agency which now provides loans to about 60,000 farmers. In 1976 it provided a total of Af 1.13 billion made up of Af 723 million short-term and Af 407 million medium/ long-term loans, though this amounts to less than 5 percent of the value of marketed farm produce. Since the major part of the short-term credit (Af 510 million) was for financing fertilizers, it is clear that AgBank has an essential role in promoting fertilizer use. A rather high proportion of short-term loans are outstanding; about one-third of fertilizer loans were overdue in 1976. This appears to be a legacy of earlier attitudes of farmers to repayment of government loans and is being corrected by firm action to instill better credit discipline in the borrowers. Repayment of medium and longer term loans is more satisfactory, because loans are based on more detailed farm plans and closer contacts are maintained between borrowers and AgBank staff.

4.85 With 13 main branches and 5 subsidiary branches in the proviaces, AgBank plans to expand its coverage by establishing two additional main branches annually. Special responsibilities of AgBank include promoting agricultural cooperatives of which 60 primary societies have received loans. These are charged a 1 percent lower interest rate, security requirements are easier and the societies earn the retall distribution margin on the fertilizers which they handle. Apart from cooperatives, AgBank assists small farmers by accepting group security where individuals would be ineligible. Under the Land Reform program AgBank collects payments for land allocated to new owners, for payment to those dispossessed. It also has a role in providing credit for farmers in new settlement schemes. AgBank had demonstrated its capacity to contribute significantly to Afghanistan's agricultural development.

4.86 Import and servicing of tractors and farm equipment has been made a special responsibility of AgBank and is being handled by a subsidiary company which will import about 300 tractors annually. Two possible dangers in AgBank's domination of farm mechanization which must be recorded are first some tendency to excessive zeal to replace animal power with high cost mechanical power, and second the pressure to bulld a large and costly national tractor workshop bureaucracy which would substitute the private workshops whlch are appearing spontaneously at present.

4.87 The Afghan Fertilizer Corporation (AFC), which is government owned, was set up in 1972 as an independent state-owned agency for the procurement and distribution of chemical fertilizers, pesticides and veterinary medicines. AFC is rapidly establishing storage depots in the provinces, and distributes to farmers through a network of 500 contracted retallers. Increasing effort 
will be needed to expand fertilizer use to smaller more remote and less innovative farmers, which will call for closer collaboration than hitherto between AFC and the extension service.

4.88 The Afghan Seed Company (ASC), also wholly government owned, has been given a monopoly of the supply of seeds and planting matertal, including imports if necessary. The company has taken over 6,500 ha of irrigable land and will be primarily concerned with production of improved cotton and wheat seed, with the objective of supplying all cotton seed requirements of 6,000 tons annually and 20,000 tons of wheat seed annually. To enable ASC to undertake this task effectively, extra resources will have to be applied to breeding, importing and testing improved varieties at the research stations before approving for multiplication and distribution. A very practical arrangement has been made with AFC through which the fertilizer retailers will also deliver seed to farmers. An important feature of ASC's operations will be the employment of contract growers for the multiplication of certified improved seeds.

4.89 Marketing of agricultural produce is handled on a commodity basis by a variety of agencies, both public sector (sugar beet and seed cotton) and private traders (most of the cereals, livestock, fruirs and vegetables). In general farmers are in a weak selling position and the most promising long term improvement lies in the formation of cooperative societies. Comprehensive recommendations for improving fruit and vegerable marketing for export have recently been approved by the Government. HLDC's operations will establish a system for marketing quality lambs for export. For cotton, the need to improve arrangements for delivery and payment by ginneries has been recognized and additional buying centres with more storage are to be built. The formation of cotton producers cooperatives which would coordinate deliveries to the buying centres should also be encouraged.

4.90 The Food Procurement Department (FPD) of the Mintstry of Finance has the responsibility for wheat procurement, storage and distribution in order to stabilize producers' prices and ensure adequate supplies for domestic consumption. FPD has the specific function of providing wheat flour and other necessities at subsidized prices to government employees and various public institutions. It has storage facilities throughout the country with a total capacity of about 290,000 tons. Over the period $1964 / 65$ to $1975 / 76$ FPD's annual average purchase of domestic wheat was 23,000 tons while imports averaged 85,000 tons (see Volume II Table 7.12). Average total quantity of domestic wheat marketed annually is estimated at about 700,000 tons which is handled by a well established system of numerous grain dealers. An effective program to ensure adequate wheat supplies and payment to farmers of the support price in good crop years will require considerable strengthening of FPD's operational capabilities and probably additional storage. Consideration should be given to the employment of licenced grain buyers and use might be made of AFC's retail distrihution agents. Alternatively consideration could be given to establishing a new wheat marketing organization shich would take 
over responsibilities for wheat procurement, storage and distribution from FPD. $1 /$

\section{(vii) Conclusions}

4.91 The conclusions of this review of the prospects for realizing the potential for agricultural development provide cause for optimism. In spite of all the disabilities of cllmate, terrain, geography, and the inadequacy of physical and social infrastructure, Afghanistan possesses adequate agricultural resources to feed and clothe 1 ts people and provide growing export earaings. Perhaps the most 1mportant factor is the quality of the farming population - patient and hardworking. Relatively rapid modernization of agriculture is, in fact, proceeding as fast as attitudes and skills can be adfusted. However, it must be accepted that weather w11, during the foreseeable future, domlnate performance from season to season. The expansion and improved efficiency of Irrigation wil mitigate the effects of drought on crop production, but pastoral systems will forever be very vulnerable. The First Seven-Year Plan is soundly concelved in establishing growth targets for agr1culture which are consistent with national priorities and in providing the range of farm inputs which are needed for these increases in production. As is inevitable in any long-term national plan, modifications in output objectives are likely. The Plan is over-optimistic about the speed of implementation of projects, in particular the large water and irrigation schemes. Good progress in construction of the Khanabad irrigation project, HLDC abatroir and BAVA ginnery are encouraging signs that the system can be geared up for more speedy implementation.

4.92 It is possible to feel some confidence that by the end of the Plan, the foundations will have been laid for sustained agricultural progress. Although the Plan target of 4.65 percent annual growth in agriculture's contribution to NDP may be over-optimistic, there are other indicators of progress towards achieving a sound rural economy based on viable famtly farms. 180,000 farmers will be clients of AgBank by $1982 / 83$. This could provide the foundation for what might be the main agricultural objective of the Second Seven-Year Plai, to bring half of the nation's 1.2 mlllion farmers into the market economy.

4.93 The major policy objectives of national food security through a wheat production and price stabilisation rograme, increase in export earnings, and rural development, require more precise definftion of objectives and tmplementation schedules. This wil shortly be completed in respect of wheat production and stabilisation with technical assistance from the US and the UK respectively. Further consideration should be given to the very attractive prospects for cotton exports which indicate that a special campaign should be mounted to encourage a faster rate of growth of production. The Rural Development Program is well concelved and the real need here is to provide more

1/ A study of wheat marketing, price stabilization and food security reserve stocks is being undertaken with technical assistance from the UK. 
resources. Specific recommendations have been made to strengthen the development programs in a number of important areas.

(1) The importance of improving the technical skills and raising the status of farmers through farmer training courses, better extension advice, participation of farmers in policy making through membership of Management boards of the various government agencies engaged in agriculture.

(ii) A review of agricultural training should be undertaken with particular attention to providing effective training at the farmer level.

(iii) Increased support should be given to promoting agricultural cooperatives.

(iv) The whole strategy for development should be based on creating viable family farm units to promote progressive intensification of husbandry practices.

(v) A national survey of the irrigation systems, current situation and development programs, should be undertaken.

(vi) An indepth review of HLDC should be undertaken after phase 2 becomes fully operational, to prepare for further development which may be expected to provide a national program for pastoral improvement.

(vi1) A review of agricultural research needs, elaboration of research programs and assessment of the organisation and resources needed, should be carried out.

(viii) An animal feed industry should be established at Baghlan as the basis for modern poultry and milk production.

(1x) The Ministry of Agriculture's capability to undertake economic and marketing surveys should be strengthened.

(x) An Agricultural Sample Census should be undertaken following the 1978 Population Census.

\section{E. Agriculture and Rura1 Development}

4.94 So far, this chapter has primarily been devoted to identifying the constraints to increasing agricultural production and the means to address them, wthout fully clarifying the broader role of agriculture in Afghanistan's development. The objective of meeting the basic needs of the population requires focussing a large share of the development effort on rural areas where the mafority of the needy population lives. It was argued in Chapter III that basic needs could most efficiently be met through a strategy that 
combined reliance on the market with sultable public programs in education and health. The key to success of this approach in rural areas is raising agricultural production.

4.95 However, the solution is not that straightforward. Agricultural resources and hence income are not distributed according to needs; neither wthin nor between regions. The areas with the best land, assured supplies of water, and access to markets are naturally the more prosperous. In these provinces, like Kunduz, Baghlan and Helmand, people in general are more prosperous than they are in the more inaccessible and poorly endowed provinces like Badghis and Ghor, or overpopulated ones like Nangarhar (see Ch. III, Table 15). The primary needs in these poorer areas are for rural development programs designed to develop infrastructure and equalize development benefits, and effective progressive jncome taxation. But regardless of the province, the skewed distribution of landholdings is a critical problem. Inevitably, the neediest are those wth the least land. Yet measures designed to increase aggregate agricultural production will primarily benefit those who own land, with benefits to the poorest trickling down in the form of increased employment, and possibly lower food prices. While this will most certainly result in improvement of the absolute incomes of the poor, 1ts impact may be slow and imeven, and it is probable that a deterioration in the distribution of income w11 result. In the medium-term, relatively little of the increased agricultural income is likely to go into effective fuchasing power of those whose basic needs are not being met at present.

4.96 A second set of concerns relates to the functioning of the market. They are often not made explictt in reviewing a country's growth strategy, but $1 \mathrm{t}$ is as well to delineate them at this early stage in the evolution of Afghanistan's productive structure. Rising incomes from increased agricultural output, concentrated in the hands of the larger farmers, result in a pattern of consumption favoring goods with high income elasticlties of demand. These are often luxury or sem-luxury items, either 1mported or produced with relatively capital-intensive technologies. The result is often the emergence of powerful interest groups of traders and manufacturers wtose prosperity depends in part on the persistence of income inequalities. From this point, the sequence has often been that the country runs chronic balance of payments deficits and the terms of trade shifts against the agricultural sector. This is an over-simpliffcation of a very complex process, but aspect of it are disceraible in many of the South Asian countries for example. Effective income redistribution and an efficlent progressive tax system can help the market to operate to Afghanistan's long-term advantage.

4.97 Clearly then, increased agricultural production is only part of the solution to meeting basic needs. Growth must be accompanied by income and asset redistribution in the agricultural sector. This can be pursued in several ways:

(1) changing systems of agricultural production through land reform, and 1mproved land tenure arrangements; 
(ii) the assessment of progressive taxes on agricultural production;

(iii) rural development programs designed to develop rural infrastructure in those areas with high agricultural potential that has yet to be effectively exploited, and integrated rural development schemes designed to 1mprove the lives of inhabitants of poor provinces that lack the potential for sustained agr1cultura11y-based development; and

(iv) the promotion of agricultural cooperatives as a means of providing small farms with access to credit, modern agricultural technology, and marketing facilities.

\section{(i) Land Reform and Land Tenure}

4.98 Recognizing that the skewed distribution of land ownership is a fundamental social and economlc problem, the Government of Afghanistan introduced a Land Reform Law in 1975. Under the law, individual holdings are limited to a maximum of:

(a) 20 ha irrigated land double cropped or in orchards, or

(b) 30 ha 1rrigated land single cropped, or

(c) 40 ha dry-farmed land.

The ultimate impact of this law is difficult to predict. Information on landholdings is unreliable, and the law itself is undergoing continuous (although minor) modification. As it currently stands, its principal effect may not so much be one of redistributing land to the landless as redistributing land among current owners so as to create more viable mld-stzed farms. There are several reasons for this. The vast mafority of the farmers own less than 20 ha of irrigated land - according to the 1967 survey only some 2.2 percent of the landholders own more. $1 /$ These farmers do, however, ow about 42 percent of the cultivable land. This is not, however, equivalent to the land available for redistribution. First, all single cropped irrigated holdings up to 30 ha, and dry-farmed holdings up to 40 ha would be exempred. In practice the majority of the larger holdings fall into these categortes. Second, the law also gives farmers two years in which to efther sell the land or distribute it among elfible family members (males 18 years of age and above) who wil 11 actively farm it themselves. Th1s is significant because many large landholdings in Afghanistan are titled in the name of an ancestor of the present farmers. These farmers currently farm the land as one unt and live as an extended family, but would break the land up among themselves and title it

1/ The average holding in this survey was estimated to be about 3.5 ha, however, partial results based on the incomplete cadastral survey suggest an average farm size significantly lower $-1.8 \mathrm{ha}$. 
In their own names to keep the land within the family. Third, much technically arable land is owned, but cannot be farmed because of inadequate water. Together, these three factors wll significantly reduce the amount of cultivable land available for redistribution. If all land in 20-100 ha range were redistributed through private action, Chapter III, Table 17 suggests only about 8 percent of the arable land would ultimately remain avallable for redistribution.

4.99 To prevent the potential proliferation of small uneconomic holdings, the program will concentrate on creating vlable farm unts of at least 10 jeribs ( $2 \mathrm{ha}$ ). Highest priority for redistributable land w11 consequently be given to farmers on adjacent farms who currently own less than this amount. Following that, priority w1l be given to sharecroppers who farmed the land subject to redistribution, landless nomads, agricultural laborers, and graduates of agricultural schools, in that order. State land is also being redistributed through settlement schemes wth holdings liwited to 10 jeribs ( 2 ha) of 1rrigated land. Nomads have priority for this land, followed by sharecroppers and landless laborers.

4.100 The amoumt of land that wil ultimately be redistributed to the poor is very uncertain. The adequacy or inadequacy of the Land Reform Law in this respect will only emerge in the course of 1 mplementation. Preliminary Indications are that this amount w11 be small, and that much of it is 11 ke $1 \mathrm{y}$ to be of the poorest quality with little or no water, and subject to unpredictable rainfall.1/ Under these circumstances one might ask whether the land cellings have been set too high. Twenty hectares of double-cropped irrigated land is a large holding in Afghanistan and insures the owner an income many times the national average. The answer to this must ultimately come from an evaluation of the pilot phase of the program, to determine whether the halfmillon or more landless poor the program alms to help are actually benefitting. $\underline{2} /$

4.101 As important as the skewed distribution of land is to development in Afghanistan, comprehensive land reform must also tackle two major related obstacles - tenancy arrangements and the fragmentation of land holdings. Although sharecropping in its many forms is widespread in Afghanistan, litele accurate information on its extent exists.3/ In the 12-village survey cited in para. 3.43 , sharecroppers comprised between 2.3 percent of cotal agricultural households in one village and 36.4 percent in another. Hovever, villages extst where all the cultivable land belongs to one man who gives 1 t out for sharecropping. Renting is not a common practice in Afghanistan - the

1) It is also felt that in some areas the domination of the landlords is still so complete that the landless would be fearful of accepting their land.

2/ Smith, et al., 으. 다.,. p. xxxvi1.

3/ For a description of sharecropping arrangements, see para. 3.45. 
above survey showed less than 3 percent of the households renting land in every case.

4.102 Sharecropping is a well established practice in Afghanistan. It serves to provlde both tenant and landlord with a measure of insurance against the vagaries of weather. It does, however, have the major drawback of discouraging both from investing in land improvement and modern agricultural technologies. As such 1t constitutes a major berrier to agricultural modernization. The current land reform program contains little to ensure the practice W11 decline - only that recipients of redistributed land must personally farm their holdings. Additional measures must be taken to modernize traditional sharecropping arrangements. These measures could initialiy include getting sharecroppers and landlords to spl1t production costs on the same basis as they split ylelds. This would help particularly in increasing the use of annual investments like fertilizer. To encourage longer term investment, some form of landlord-sharecropper contract could be instituted which would guarantee a sharecropper's right to farm the land for, say, ten years. With such secur1ty of tenure, sharecroppers would be much more willing to help invest in land improvements. Ultimately though, tenure arrangements will have to shift to an economically more efficient rental basis. This could be incorporated in the land reform pilot study suggested above. The transformation is a remarkably simple one - landlords should be told to insist upon a fixed payment that could equal his average share of the past few years, for instance. Payment could st111 be in kind.

4.103 Land fragmentation is a strong disincentive to land improvement, as the capital costs associated with, for instance, one contiguous hectare are usually considerably lower than those associated with the same amount of land spread over several non-adjacent plots. It is a major problem in Afghanistan as Islamic law dictates that all immediate relatives receive a share of an estate. The consequence of this practice over the centuries is family holdings spread over numerous plots of extremely small average size. I/ Consolidation of such fragmented holdings into unified plots is essential for efficient modernization of agriculture and should be an integral part of the overall land reform program. Hence, as land ownership is ascertained for purposes of taxation and redistribution, measures could be taken simultaneously

4.104 Land retorm is of critical importance to Afghanistan's future, and the Government has shown an impressive wllingness to face the 1ssue squarely, The problems, however, are immense. First there is the lack of an adequate base of information on land ownership. Second there is the sheer size of the administrative effort which is required. Third there is the power and influence of the large landowners. All this probably means that land reform will be partial and long drawn-out. The uncertainty which land owners who are close to the ceiling ma feel, will undoubtedly reduce their willingness to

1/ The mission was quoted a case by the Cadastral Survey Organization of a square kilometer in Paktia province in the east being subdivided into about 4,000 plots. Average plot size was about 0.025 ha. 


\section{PRIVATE NON-AGRICULTURAL ENTERPRISES}

5.01 Although 1t is land-locked, Afghanistan's situation along the east-west trade routes has always given it access to foreign markets. With the limited range of domestic products there has been reciprocal demand for foreign goods. For the most part non-agricultural enterprises in the private sector in Afghanistan have therefore evolved around trade services. Informal financial institutions, outside the organized banking sector, have developed in parallel, dealing in foreign trade transactions, domestic agricultural production and trade, and of late, the increasing flow of workers' remittances. The typical scale of private non-agricultural enterprise in Afghanistan is small and family-based, but collectively they dominate external trade, handicrafts production, domestic distribution, and transport services. In recent years there have been wary and frequently unsuccessful attempts to move to larger scale enterprises in industry, urban distribution, and transport. There is at present evident interest in accelerating this process. Many traders and landowners have accumulated large agricultural and trading profics in recent years, and now seek to diversify their activities. With changing social perceptions following from increasing contacts with the outside world, the middle-class no longer seems to regard careers outside the army and the bureaucracy as unworthy of pursuit. There are still formidable barriers to this transition, however, in the form of Government restrictions and disincentives, as well as a shortage of educational and managerial know-how needed to operate large and complex enterprises.

\section{A. Role of Private Non-Agricultural Enterprises in the Economy}

5.02 It is likely that more than 40 percent of GDP and employment in Afghanistan originates in non-agricultural private enterprise (See Table 1 , p. 9). About a third of this would be secondary activities such as handicrafts and industry, while the balance consists of services. The major private sector activities outside agriculture are as follows:

\section{(i) Handicrafts}

5.03 Bandicrafts constitute about 8 percent of GDP and engage about 18 percent of the settled labor force. Employment in handicrafts is probably many times that of industries, and handicrafts also contribute a larger share of the GDP (see Table 1). Production is carried out in families and most of the work is done by women and chlldren. Products are specialized by region. Carpets and rugs are concentrated in the north and north-west, textlle embroldery and leather goods are found mostly in the south (Kandahar region), wood and stone carving is concentrated in the north-eastern provinces, and jewelry and lapidary (i.e., crafting of lapis lazuli stones for Inlay in precious metals and as smali figures) are mostly carried out around
Kabul. 
5.04 Of the handicrafts, carpets and rugs constitute the most significant item contributing about $\$ 24 \mathrm{mlll}$ on or about 8 percent of annual exports $(1976 / 77)$. In addition, a considerable volume of carpets and rugs may be exported through unofficial channels. Afghan carpets are of the hand-knotted, pure wool variety and are greatly in demand in Western Europe. Of late, the phenomenal rise in the prices of Iranian carpets has encouraged buyers to swltch to Afghan carpets. Among other 1tems, sheepskin Jackets have been a growth item in recent years and remain fashionable in Western Europe. The same is also true of other rypes of leather goods, such as handbags and sandals, and embroldered textiles. There has also been a recent upsurge in demand for lapis lazulf products. There are a few large firms, mainly dealing in carpets, which export directly to their market outlets in Western Europe and USA but for the most part sales are made by a multitude of small $10 \mathrm{cal}$ traders to the representatives of foreign buyers and tourists.

5.05 Production techniques in handicraft industries are simple and nonmechanfzed; they have barely changed for generations. Apart from carpets and rugs, the quality of handicraft ltems produced in Afghanistan is generally not very high. Often labor-intensive work such as embroidery is put into inadequately prepared sheepskin coats and leather goods. Leather is poorly cured, kilns are too small for proper firing of pottery, and jevelry makers have no proper polishing equipment. Af ghanistan has not yet improved its techniques of handicraft production. Consequently, in spite of low wage costs, Afghan handicraft products are sometimes not competitive in export markets. Being dispersed throughout the country, in probably more than 80,000 establishments, and lacking any form of association, handicrafts are generally inelastic in volume and design of production. These are decermined either by the irmediate local market they serve or the trader who in many instances also provides production materials and in some cases the operating capital needed.

5.06 The maln assistance which the handicrafts sector recelves from Government is in securing export orders. This is done through the Export Promotion Department in the Ministry of Commerce wh1ch has been quite successful in developing export markets for Afghan carpets, and locating producers to execute orders. It does not, however, provide credit to producers. The bazar money traders art the main source of finance and their lending is at very high rates of interest. Furthermore, the credit they provide is shortterm. The recently established Export Promotion Bank could ease the sector's financing needs by lending to traders who could in turn pass on the credit to producers. However, like bazaar flnance, this type of credit is also shortterm and would not permit a handicraft producer to purchase better tools for example. There is thus a need to create a longer term source of finance. The proposed Development Assistance Fund of the Industrlal Development Bank has the potential to meet this need (see para. 5.27 below). The only other direct support to handicrafts is provided by the Afghan Handicrafts Promotion Center, a semi-public institution with equity participation by the Chamber of Commerce and Industries. While the charter of activities of this Center is quite wide and includes technical and commercial assistance to producers, its present activity is confined to the management of the Afghan Handicrafts Emporium. 
The Seven-Year Plan (Volume I, Pp, 134-135) indicates an awareness of the problems but does not propose a concrete program of action.

5.07 The following program of actions to be taken over time can be jelineated:

(a) Establishment of common regional processing factlities for groups of producers e.g., bleaching and dyeing of yarn or woven fabrics, curing and chroming of leather, kilns for ceramics, etc. Where appropriate these could be on a cooperative basis.

(b) Encouragement of partial mechanization of the production processes through access to credit and demonstration services by the Afghan Handicrafts Promotion Center which should also provide the necessary training.

(c) Quality control facilities such as certification by the Afghan Handicrafts Promotion Center. This would considerably alleviate the foreign buyers ${ }^{\circ}$ uncercainties with respect to the quality of the merchandise.

(d) Liberal credit facilities through the Export Promotion Bank, the Commercial Banks and the Development Assistance Fund of the Industrial Development Bank. The latter would be of particular importance as a source of longer term credit. Considerable promotional effort, however, will be necessary in this regard.

J.08 These recommendations are presented as a set of objectives for the Government to work towards over time, rather than proposals for immediate mplementation. The institutional base is simply not strong enough at present o support these activities and inserting Government controls and weak institutions into the sector at this point would do more harm than good. The Export "romotion Bank and the Development Assistance Fund for example are just getting Ff the ground and it seems reasonable for them to cut their teeth on their primary objectives rather than launching into wholesale support of handicrafts without the experience and the regional branch network which would be needed or this purpose. The most promising initial approach would seem to lie with ie Afghan Handicrafts Promotion Center. Steps should be taken to strengthen 1t and expand its responsibility. At a later point in time it could be asked 'play an 'extension' role in guiding producers who need financing through ie procedures of the commercial banks and the specialized banks.

5.09 Afghanistan's varied and attractive handicrafts represent a promising tential for expanding output and income. The prospects on the demand side wie good. Supplies are small relative to total world demand for these items and erstwhile competitors such as Iran are emerging as buyers of Afghan indicrafts, as a result of their new affluence. Demand would be given an iportant boost if the Government were to adopt an active program of promoting. tourism. Tourist arrivals have been virtually stagnant since 1970 . Exchange 
rate policies are another area in which Government pollcy w111 be important. Given the right policies and greater institutional support there is evidence that the private sector will respond effectively in this as in other areas.

\section{(11) Artisans and Sma11-Scale Industrial Enterprises}

5.10 There 1s a small but rapidly expanding informal industrial sector in Afghanistan. It is located mainly in Kabul, but is represented in the other major toms as well. It includes such enterprises as auto repair establishments, machine shops with facilities for metal-fabrications, repair shops for electrical and electrontc goods, furniture making, etc. The scale of these enterprises is larger than the average handicrafts establishment but would probably not have machinery of a value much more than Af 100,000. Compared to the employment in the handicrafts sector, the labor force in this type of enterprise is smal1. Navertheless, these small-scale operations perform essential economic services. For example, the auto repair facilities and sma 11 machine shops are almost entirely within this sector. As in many developing coumeries, however, there is very little data on this group of activities, which contributes to the underestimation of their importance and potential.

5.11 These establishments occupy the intermediate stage between handicrafts and Industrial establishments and have the potentlal to progress into the latcer. This has been the pattern in other developing economies, India and Pakistan for example, which may be renlicated in Afghanistan. Already such transformations are taking place. Kabul Felez, a small metal fabricatfon enterprise is a case in point. This encerprise started as a small repair shop by a graduate of the Kabul Polytechnic with hardly any capital. Progress has been very rapid however, and the original repair shop is now one of the prime suppliers in Afghanistan of steel furniture and other fabrications. Simflar potential is obvious in many other cases. Some of the auto repair shops for example could over time graduate into dealer franchises and eventually into assembly. Encouragement of such enterprises which is proposed through the Development Assistance Fund (DAF) of the Industrial Development Bank (IDBA) could be enormossly productive in fostering entrepreneurial calent, employment, and the use of intermediate technologies which are more appropriate to Afghanistan's stage of development.

5.12 It would be idle to pretend, however, that current proposals do more than scratch the surface of the potential which exist. For small-scale enterprises in Afghanistan. The present and proposed development is concentrated in the Kabul area, yet tie major potentials would seem to be related to the growth of agricultural production and incomes in a widely dispersed regional pattern. This dispersal, which has probably hampered the growth of medium-scale enterprises in Afghanistan, can be turned to advantage if local craftsmen can be provided with the small amounts of capital they need to upgrade the quality and increase the quantity of their output. The commercial banks could play a significant role in fostering and financing such activities in the cities and towns other than the capital. The regional network, which IDBA proposes to establish over time, would go a long way in this direction through providing entrepreneurs outside Kabul with access to the proceeds of the DAF. 


\section{(11i) Industrial Enterprises}

5.13 The history of the private sector industrial enterprises is fairly recent, dating back to the pioneering efforts of Bank-i-Melli, established under Government patronage. (See para. 2.19.) The etatist pollcies of the $1950^{\prime}$ s severely restricted private activities and the development of the sector on an expanded scale really began only during the late $1960^{\circ} \mathrm{s}$, in response to the 5-year tax hollday and other incentives provided under the 1967 Foreign and Domestic Private Investment Law (FDPIL). The main benefits granted were as follows: (a) five-year exemption from income tax (b) fiveyear exemption from import tarfffs on capital goods, raw materials and spare parts, and (c) ten-year exemption from export taxes. $1 /$

5.14 Private mediun-scale industry in Afghanistan consists of about 130 establishments employing about 10,000 persons. The 1 ist of major industrial enterprises in Volume II, Table 8.4 shows five private sector companies with an employment of 200 or more persons. The largest, a tannery and shoe factory, employs about 500 persons. Two of the largest private manufacturing untes have minority forelgn equity participations. Valued at the original investment, total private foreign investment in these firms would probably not be much more than Af 500 million. For a country of Afghanistan's size, even taking into account the low income per capita, this level of foreign investment is exceptionally small and it is legitimate to ask why this has been the case. The reasons probably lie mainly in the adverse investment climate for all private industrial investment, but there are other contributing factors. As far as export-oriented projects are concerned, although Afghanistan has low wage costs and cheap raw materials these advantages are compensated by the high transport costs. Low wage costs are often lllusory in the absence of tralned and skilled labor. With regard to 1mport substitution, forelgn suppliers have usually preferred to serve the small Afghan market by exports from a larger manufacturing base, rather than by establishing a small-scale production facility within the country.

5.15 Private medium industrial establishments in Afghanistan appear to have the following characteristics:

(a) There is a heavy concentration in import-substituting industries. 72 out of 108 FDPIL approved projects fall into this category constituting 80 percent of the total investment. The principal industry groups represented are rayon weaving ( 18 projects), plastic products including footwear ( 12 projects), and metal fabrication (8 projects).

1/ The FDPIL was revised in 1974 so that at present the details do not quite correspond to the 1967 provisions. A detailed description of the provisions of the FDPIL and the procedures which it involves are given in Vo1. II, Table 8.7. In substance it remains a very favorable program of incentives from the standpoint of increasing the profitability of private industrial investment. 
(b) Of the remainder, 28 are 1dentifiable as export-oriented projects. The most 1mportant of these are leather and tanning ( 10 projects), and raisin processing ( 9 projects).

(c) About 86 percent of the total est1mated investment is concentrated in the Kabul area, with no other city accounting for more than 4 percent.

5.16 Almost all the enterprises referred to above were e1ther under construction or in operation in 1973. Since then by mid-1977 only 28 new industrial projects had received final approval under the FDPIL, and only six of these were actually in operation. For the rest, the promoters seem to have elected to move rather sedately on implementing their projects. Twenty-nine other projects were at various stages of approval. The complex approval procedures with their final stage involving a dectsion of a group of cabinet ministers, normally take about 12 months to complete. In 1976/77 investment proposals received totalled Af 172 millon while approvals totalled Af 94 ufllion. This is well below the average 1nvestment in private industry during the preceding seven years of Af $254 \mathrm{million}$ and does not augur well for the attainment of the present Plan target of over Af I billion a year of private industrial investment.

\section{(iv) Trade Services}

5.17 Trade services make an even greater contribution to GDP than handicrafts though they employ a smaller number of the labor force, about 6 percent. Domestic distribution is almost entrely in the hands of the private sector as are most of the commercial imports (i.e., those not financed by foreign aid) and exports. The major exceptions are the commodities for which Government trading monopolies exist. These are imports of sugar, petroleum and tobacco and exportc of natural gas and cotton.

5.18 The typical profile of a local trader is that of a surplus farmer diversifying into trade, and perhaps also into transportation services. His relations with his customers are long-established and he is an important pillar of his small community. His outlet is a small store in the nearest market town. His scale of operations is generally small, around Af 100,000 with access to credit from larger traders in the urban areas. These larger traders often operate as money lenders as well. They are generally wholesalers with traditional business links with regionally scattered groups of traders clustered in the bazaars of small towns and the main villages along the highways. of late, wore and more of the large traders are engaging in retalling imported goods in the urban areas. The scale of operations is significantly higher in foreign trade. Generally, a minimum working capltal of about Af 10 millon (about $\$ 200,000$ ) is needed and the trade is dominated by established merchant houses for whom this is a traditional occupation. These traders do not, in general, belong to the landed gentry although there are a few exceptions. Trading is still not looked on as a socially desirable career although there are signs of change and an increasing willingness in the new generation to consider careers in industry and trade. 
VI. STATE ENTERPRISE IN INDUSTRY AND MINING

\section{A. Background and Characteristics}

6.01 In Chapter II we described the beginnings of industrialization in Afghanistan in the $1930^{\prime}$ 's through the ploneering efforts of Bank-1-Me11i which by the end of the decade had established joint-stock companies for cotton ginning, cotton textiles, edible oil extraction and sugar refining. These efforts had the patronage and support of the Government through minority equity partic1 pation and the award of monopoly concessions. Despite these, industrial development had not proceeded very far by the $1950^{\prime} \mathrm{s}$ and there was impatience whth the pace of private investment. As a result, the Government of Prime Minister Daoud set up, with foreign aid and technical assistance, a number of wholly state owned and operated enterprises, producing textiles, cement, sugar and metal products. Public sector expenditures on industry and mining increased from virtually zero to Af 2.6 blllion during the First Plan period (1957/58-1961/62) and to Af 8.4 bfll1on during the Second Plan period (1962/631966/67). By the mid-sixties the pendulum had swung back. The state enterprises were not regarded as successes. There was general agreement that they were poorly managed and there was a substantial fiscal drain on their accout. As a result there was an attempt to promote private investment through the formulition of a generous program of incentives under the Foreign and Domestic Private Investment Law of 1967 (see para. 5.13). There was promising initial response to the publication of the law.

6.02 The coming of the Republican Government in 1973, however, marked a revival of the etatist policies of the $1950^{\circ} \mathrm{s}$. The banks were nationalized and in the process the Government acquired majority shareholdings in the largescale private sector industries which were subsidiaries of Bank-i-Melli. The effect of this was to bring almost all large-scale industry into the public sector, representing the majority of industrial investment though not of outpur and employment. The public sector is now once again seen as the medium of Afghanistan's industrialization. The provision for private sector industrial investment during the present Seven-Year Plan period is Af 8.5 billion (about $\$ 180$ milion), compared to Af 45.8 billion in the public sector (about $\$ 1$ billion). More important, as pointed out in Chapter V, even the Iower allocation for private industry is merely notional, and unlikely to be realized if current investment trends continue. Table 23 shows the acceleration of public industrial investment implied by the Plan. 
Table 23: INVESTMENT IN STATE ENTERPRISES, 1957/58 to 1975/76 (In billion afghanis, at current prices unless otherwise specified)

\begin{tabular}{|c|c|c|c|c|c|}
\hline & $\begin{array}{l}\text { First } \\
\text { Plan } \\
1957 / 58- \\
1961 / 62 \\
\end{array}$ & 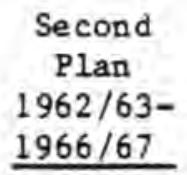 & $\begin{array}{l}\text { Third } \\
\text { Plan } \\
1967 / 68- \\
1971 / 72 \\
\end{array}$ & $\begin{array}{l}\text { Annua 1 } \\
\text { Plans } \\
1972 / 73- \\
1975 / 76 \text { /a }\end{array}$ & $\begin{array}{l}\text { Seven-Year } \\
\text { Plan } \frac{/ b}{19} \\
1976 / 77- \\
1982 / 83\end{array}$ \\
\hline $\begin{array}{l}\text { Industry } \\
\text { Mining }\end{array}$ & $\begin{array}{l}\cdots \\
\ddot{ }\end{array}$ & 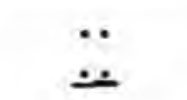 & $\begin{array}{l}5.5 \\
3.7 \\
\end{array}$ & $\begin{array}{l}1.8 \\
5.4 \text { lc } \\
\end{array}$ & $\begin{array}{r}37.8 \\
8.0 \\
\end{array}$ \\
\hline Total & 2.6 & 8.4 & 9.2 & 7.2 & 45.8 \\
\hline
\end{tabular}

Note: The subsector breakdowns up to the Second Five-Year Plan are not available. The investments were, however, mainly in industries.

la The component for $1975 / 76$ is an estimate.

Tb At $1975 / 76$ prices.

Ic Includes the Mazar-1-Sharif Fertilizer Plant.

Source: Ministry of Planning, Kabul.

6.03 The most 1mportant public sector incustries are those based on cotton (ginning, oil products and cotton textiles): Afghan Textile's three factories Bagrami Textile, Balkh Textile, and Spinzar Cotton-ginning; Balkh Ginning, Pressing and 011 ; and Helmand Cotton and 011 . Other major sectors are construction materials (Ghori Cement, and the prefabricated concrete plant), urea fertilizer, and sugar. The public sector produces all of Afghanistan's cement, fertilizer, ginned cotton and sugar and a significant part of the textiles. The emphasis is on import substitution with the exception of ginned cotton; cement and fertilizer have been exported in the past in minor quantities but domestic consumption has already caught up with existing capacities. Textiles are produced entirely for the domest1c market; there is at present a ban on exports of textiles. The public sector, indeed the country, has hardly any production facilities for capital goods and the needs are thet through imports. The Jangalak Ironworks which currently undertakes production of spare parts, metal fabrication and metal furniture on a limited scale, is the only exception.

6.04 Since 1973 there has been a noticeable improvement in the degree of capacity utilization among the public sector industrial enterprises. This has risen to about 70 percent and above in many cases. This contrasts sharply with the situation a few years ago, particularly in cotton ginning. The rising production of seed cotton and buoyant export demand has largely eliminated excess capacity and indeed substantial expansion in capacities wll be necessary. In fertilizer, the capacity limits are likely to be reached during the current year while cement production is diready at the capacity level. Capacity utilization in textlles could improve further but for the export ban. There are exceptions though, the most prominent one being the sugar factory, 
where capacity utilization is low because of machine obsolescense and inadequate maintenance. Another type of technical problem frequently encountered is raw materials of improper specifications leading to breakdowns. Other cases of low capactty utilization are traceable to managerlal and administrative deficiencies though here also there has been some improvement in the recent past.

6.05 The mining sector in Afghanistan is entirely within the state sector and private enterprise is legally barred from participation. Its origin is stil1 more recent than the industries: 1ndeed, there was no systematic attempt to exploit the country's mineral resources until the $1950^{\prime}$ s. Af ghanistan's mineral resources offer the porential for considerable future development. The Government has rightly resisted the temptation, hitherto, to jump into major mineral exploitation projects without the survey and feasibillty work which are needed to establish their viability. A stage has now been reached where intensive studies must be mounted so that decisions can be taken on the selection of projects and their phasing.

6.06 Afghanistan has about 100 million tons in proven coal reserves with another 400 milion tons in the probable category. Domestic consumption is less than 0.2 million tons per annum at present, wost of it in thermal power plants, thile about 15 percent is used in the form of briquettes for household purposes. It is only recently that the existence of such vast coal reserves has been proven which explains the massive degree of underexploitation. As for hydrocarbons, natural gas reserves are estimated at abour 120 billion cubic meters. Current production is about 2.5 billion cubic meters of which about 80 percent is exported by pipeline to the USSR, and the rest utilized in the fertilizer and thermal power plants in the north of the country. The country has small deposits of fuel o11, current proven reserves are about 10 million tons. There is no domestic refinery and the entire annual consumption of fuel $0: 1$ and lubricants is imported at a cost of about $\$ 28$ million.

6.07 Aside from energy resources, Afghanistan has two major mineral resources, izon ore and copper, which have not yet been exploited. The iron ore deposits are estimated at about 1.7 b1llion tons (about 62 percent grading). Exploftation possibilities are, however, limited by the inaccessibility of the area where che deposits are located (Hajigak in the Koh-1-Baba range at heights of over 12,000 feet), the lack of a domestic market and the distance the ore will have to be transported for export purposes. The Government has recently initiated $a$ series of detailed technical and economic studies on Hajigak iron ore. As regards copper, the deposits at Alnak are estimated at about 4.7 milion toss of metal (ore equivalent of about 280 million tons) and offer good mediu-term possibilities for export elther in ore concentrate or in metal forc. Apart from the above, Afghanistan has several minor mineral deposits oz chromite, lead, zinc, talc, barite, rock salt, etc., and precious and semi-precious stones. There is exploitation of some of these deposits, but the to:al output is low. 


\section{B. Management of State Enterprises}

6.08 State enterprises in industry and mining are divisible into three types of management arrangements: enterprises that are organized as departments of ministries; Tasadys (i,e. semi-autonomous enterprises fully owned by the Government); and majority shareholdings by organizations which are themselves under government control. The differences in government control procedures are less marked in practice than in principle. With the exception of Afghan Textiles which controls 3 major formerly privately-owned cotton textile plants, all other enterprises are closely managed by the controlling ministry with all major decisions requiring ministerial approval. Afghan Textiles constitutes an exception and operationally it remains essentially as it was under private enterprise, Government intervention being limited to broad policy questions.

6.09 The only important industrial enterprises which form part of a Ministry and operate as a branch of the government service, are the fertilizer factory and thermal power plant at Mazar-i-Sharif; these are part of the Ministry of Mines and Industries. All mineral enterprises are run by the Mineral Exploitation Department of this Ministry. The largest group of state enterprises are the Tasadys. Altogether there are 41 of these at present, falling under 10 different ministries. All report to the Ministry of Finatice on budgets and accounts. However, only about 11 of these are clearly industrial enterprises, 10 of them under the Ministry of Mines and Industry, and one (the prefabricated housing unit factory) under the Ministry of Public Works. Six of the remainder are partly industrial in character. The largest single manufacturing company in Afghanistan -- Afghan Textiles -- is controlled by Bank-i-Mell1, which, following nationalization, has itself come under government control. Afghan Textiles is the majority shareholder in the Spinzar Company at Kunduz and Jangalak Ironworks.

6.10 The management of state enterprises in Afghanistan is characterized by an extraordinary degree of centralization as provided for under-the revised Law of Tasadys. 1/ Each Iasady is headed by an Amir (in law the Minister concerned), who determines policy, approves annual plans and budgets, supervises internal management and appoints all staff except the most junior ranks. The charter of each Tasady will specify whether control is to vest with the Minister or with the 'High Council' under his chalrmanship. The management, headed by an official with the rank of President, is therefore essentially the executive arm of the Minister. In addition, the Tasadys are also characterized by two other kinds of rigid centralized controls: (i) plant management is required to refer all major purchases (1.e., between US\$3,500 to US\$9,000 depending on the plant) to the Minister for approval; and (ii) prices and mark-ups are decided by the Minister. The need for such extensive authorization deters Management

1) The revision of the Tasady law was promulgated in late 1977. While its overall objective is improved management, the emphasis on centralized control may exacerbate the deficiencies which were present under the original law. For a detailed treatment of the management of the public sector enterprises: see IBRD Report No. 1245-AF, Chapter IV. 


\section{PHYSICAL INFRASTRUCTURE}

7.01 Physica 1 infrastructure is the foundation for social and economic development. Transport and commication systems integrate the country both economically and socially, and allow the flow of goods, services and information. Farmers in previously inaccessible areas have the possibility of producing for markets, of speciallzing in production according to comparative advantage and importing many different goods and services in return. Trade on the national level expands, and with it employment and incomes. Everyone gains access to more and varled goods and services (including education and health services), which raise the standard of living. Access to the international economic system that the creation of transport and communications infrastructure can provide serves to reinforce these trends. But infrastructure goes far beyond roads - power and water distribution systems are of particular importance to Afghanistan. The provision of power and energy is an essential to the everyday functioning of the economy, as well as to the process of industrialization. However, it serves much more basic needs as well - lighting, cooking, heating and operating water pumps - needs that are felt by every household. The ability to meet these needs provides a test of the success of development.

\section{A. Transportation}

7.02 Twenty years ago someone wrote that "The economic organization of Afghanistan resembles a wide sea dotted with islands of economic activity, each one more or less limited to its own local market, primarily because of inadequate transportation." $1 /$ The heavy emphasis on road infrastructure during the First and Second Five-Year Plans did much to integrate the major geographical regions of the courtry, and particularly the main commercial centers. Until then more trade probably took place between individual regions and the outside world than between regions themselves. As recently as 1960 , the regional differences in the price of wheat (then, as now, the principal commodity traded) were as high as 150 percent, but by 1966 ; they had dropped to about 30 percent, almost solely because of the new all-weather roads. $2 /$ by 1977 , the major regional prtce differentials had almost entirely disappeared (except for transport costs) as a result of greatly improved communications. Nevertheless, many villages are st11l extremely 1 solated and only an estimated one-third to one-half of all foodgrains enter the market.

\section{(i) The Transport System}

7.03 Roads are the principal mode of transportation for both internal and international traffic. The total length of all types of roads in the country is estimated at $17,000 \mathrm{~km}$. In 1975 the all-weather road network extended

1/ Quoted in Fry, Maxwell J., The Afghan Economy. E.J. Brill, Leiden, Bolland, 1974, p. 56.

2/ Fry, 오. 서., p. 58 . 
$9,200 \mathrm{~km}$ of which $2,560 \mathrm{~km}$ were asphalt and concrete highways. The remaining roads are gravel roads, tracks and improved earth roads many of which are impassable for much of the year. The highway network pattern is largely the result of the main geographic and economic features of the country. The principal agricultural areas and major population centers are linked by a highway system which circumvents the Hindu Kush mountains in the center, and which links Kabul in the east with Baghlan and Mazar-i-Sharif in the north, Kandahar in the south and Herat in the west (see Map IBRD 10642R). The roughly circular network is presently being completed with the construction of the SheberganMaimana-Herat link. Trunk roads radiate from this circular network into urban centers like Kunduz, Jalalabad and Gardez as well as into neighboring countries through which most of Afghanistan's international trade is routed. In general, the length of the primary highway network in Afghanistan is reasonable and adequate to serve the major regions of the country. The principal need is to improve certain existing sections and to upgrade their maintenance. The secondary and tertiary roads linking the rural provinces, small towns, villages and farms with the major highways, are generally substandard to handle traffic at reasonable cost. In many cases, they constitute real bottlenecks to the economic development of their hinterlands.

7.04 A considerable amount of traffic is carried by animals, mostly camels and donkeys, even over long distances and on routes not yet served by the road network. However, access to motorable farm-to-market roads is essential if farmers are to enter the market economy on a large scale. Afghanistan's present road system is most deficient in this respect. The road density of .027 $\mathrm{km}$ of road per square kilometer of land places Afghanistan among the bottom fourth of developing countries. Although a scattered population and the presence of large uncultivable expanses do bias the road density figure downwards, the ratio of roads to cultivated land of $0.354 \mathrm{~km}$ of road per square kilometer of land is still very low.

7.05 As a land-locked country, international transport routes are of vital significance. The following are the main routes presently used:

(i) Commercial road traffic across the border is prohibited by the USSR. However through its agency Sojuzneshrrans, the USSR offers Afghanistan extensive land transport links to the Pacific (via Vladivistok), to northern Europe and America (via Leningrad) and to southern Europe (via Black Sea ports) based upon a combination of rallroad and shipping services. The Russian railway system (gauge 1.52 meters) has a station $1 \mathrm{~km}$ inside Afghanistan at Iorghund $i$ and on the Russian side of the Amu Darya River at Termez, which is connected with Afghanistan by means of river barge services to Hairatan $(13 \mathrm{~km})$ and Sherkhan $(183 \mathrm{~km})$.

(ii) Via Pakistan: With very rare exceptions, all the cargo to the port of Karachi must be transshipped to Pakistan railway lines (gauge 1.66 meters) mainly at Peshawar (1450 km) and sometimes 
at Chaman $(938 \mathrm{~km})$. The port of Karachi has considerable congestion problems and Afghan commerce is often given a low priority. The oferation of through trucks between Afghanistan and Indfa is not permitted oy Pakistan, and cargoes, mainly fruits, must be transferred first to Pakistan vehicles and then to Indian ones.

(111) V1a Iran: Access to the sea is by way of the twin ports of Khorramshahar and Bandar- -1 -Shahpur, both heavlly congested and with time consuming clearing procedures. The ports are located about $2,300 \mathrm{~km}$ from Herat. The cargo is normally expected to be moved by Iran Railway (gauge 1.435 meters) from Mashhad ( $240 \mathrm{~km}$ west of the border and $320 \mathrm{~km}$ from Her3t), although Iranian trucks can be used in case of necessity. The transit treaty between Iran and Afghanistan does not permt the through movement of commercial vehicles from a city in one country to a city in the other. However, Afghan vehtcles are permitted to operate up to the rail terminal in Mashhad and Iranian vehicles up to Herat. Af ghan vehicles transiting Iran have so far been permitted to operate without difficulties.

7.06 In 1975, Afghan1stan's export, import and transit amounted to about 950,000 tons; 70 percent was moved through the USSR, 20 percent through Pakistan and only 10 percent through Iran. More than half of the total interational cargo of the country was moved through the river port of Halratan located at the border with the USSR. Firm information for 1976 was not available by mid-1977, but it is estimated that the total was about 10 percent higher than in 1975 .

7.07 The country's civil air transport system has been developed over the last 20 years with American and Russian ald. It now comprises 20 airports and alrstrips of which Kabul is by far the most important. Domestic civil aviation serves an administrative and social function by providing access to areas with poor or non-extstent road connections. Internationally, because of Afghanistan's remoteness from the major tourist generating countries, aviation is the only realistic means by which the cautry's considerable attraccions could in the future be made accessible to the international mass tourist market. International aviation in Afghanistan is very much centered on Kabul airport, which was opened in 1962. In 1969 it handled around 55,000 passengers; this rose to over 106,000 in 1976, which represents a significant annual growth rate of almost 10 percent (see Volume II, Table 10.2). The other international airport of the country, Kandahar, handled only 6,600 passengers in 1976, and operates main $1 \mathrm{y}$ as an alternative to Kabul when Kabul is fog or snowbound. The traffic distribution during the course of the year has significant variations mainly due to the impact of the cllmate on tourist travel to Afghan1stan. In Kabul the peak month in 1976 was August with about 12,500 international passengers, whereas in Tanuary, February and March it dropped to almost half of the number. The total amount of international cargo loaded and unloaded at Kabul airport in 1976 was almost 6,000 tons. For domestic traffic, Kabul is again the most important airport; in 1976 it handled around 12,000 domestic passengers representing over 40 percent of national traffic. 
7.08 The remaining two modes are river transport and pipelines. River transport takes place only on the Amu Darya River for international traffic between Afghanistan and the USSR, wlth all commercial vessels owned and operated by the latter. 1/ The main river ports are Sherkhan and Hairatan. The ports are administered by the Port Department under the Ministry of Commerce. Approximately 100 miles of pipelines link the gas fields around Shebergan with the Russian border at Kleft.

7.09 No raflway extsts because in some areas the mountainous terrain makes construction too difficult and expensive, while the volume of bulk products for long distance hauls is at present not significant. Nevertheless, the Government is considering the possibility of butlding some 1,800 $\mathrm{km}$ of railways, which according to preliminary estimates will cost about $\$ 1.2$ bi111on. It is proposed to spend about 80 percent of that amount during the present Seven-Year Plan, 1976/77-1982/83, and the remainder during the next Plan.

\section{(11) Inst1tut1onal Framework}

7.10 Two organizations bear responsibility for the construction and maintenance of roads: The Road Construction and Maintenance Department of the Minfstry of Public Works (RCMD), and the Rural Development Department (RDD). RCMD is responsible for administering the primary and secondary road network outside the mumicipalities. Feeder roads from the farmland to the main roads and woleswali centers as well as small irrigation structures and bridges are the responsibility of RDD. RDD's programs will be discussed in the section on rural infrastructure below. Roads in the Helmand and Paktia project areas are the responsibilities of the respective development authorities, both under the Ministry of Agriculcure and Irrigation.

7.11 The RCMD is now divided into two directorates: The Roads Engineering Directorate and the Road Maintenance Directorate. The present organizarlon suffers from many deficiencies - continuous changes and transfers of key personnel, salaries too low to attract qualified people, decision-making power concentrated in a very few high level officlals, lack of a clear definition of responsibilitles, absence of appropriate planning capabilities, etc. Some of these problems are inherent in the overali administrative system of Afghulstan, and some are specific to RCMD. In the circumstances it is surprising that the maintenance of the primary road system has been generally adequate. The failure has been on the secondary and tertiary road network where maintenance and road improvements should play a far more significant role in the evolution of the road network than they do at present.

7.12 There are no Afghan private road construction firms and no effective government incentives to create one. There are of course small private contractors capable of doing work on culverts and other minor structures, but

1/ Although in the eastern region significant quantities of logs are floated down the Konar River to the Jalalabad area for road transportation from there. 
there is a limit of Af 5 million on any contract to be let to them. Road construction work is now mainly done by military conscripts under the direction of Army officials. As a consequence of the lack of private road construction 1ndustry, there is an absence of competition, delays i. road construction works, uncertainties with respect to road construction costs, time-consuming procurement procedures, etc.

7.13 Civil aviation is the responsibility of the Afghan Air Authority. It also has serious institutional and administrative difficulties. By 1973, chere was general agreement that the most effective way of dealing with the administrative difficulties confronting civil air navigation would be to establish a separate entity with general responsibility for the provision of civil air navigation, air traffic control and air comounication services. That entity, to be called Air Navigation Services (ANS), was supposed to be run on a commercial basis and to be organized to provide clear lines of command and communication between its headquarter's staff and its field staff. By mid-1977, the new institution had not yet been established.

\section{(iii) The Strategy for the Development of the Iransport System}

7.14 The economic development of Afghanistan is seriously affectec by its geography and topography. The Government is aware that one of the key objectives must be to establish an efficient transport system. The wide dispersion of population calls for a rather extensive transport network, mainly of low-cost low-volume roads. I/ However, the physical features of the country work in large part against such a strategy by raising construction and maintenance costs even on low-cost tertiary roads, and making transportetion costs high. These features include:

(1) the rocky, mountainous terrain, which causes road and, obviously to an even greater degree, rallroad construction to be difficult and costly;

(ii) the small size and relative inaccessibility of areas with economicaliy exploicable resources requiring ar extensive network with low traffic volumes and hence low standard roads scattered all over the country;

(iii) the harsh climate with extreme daily and seasonal temperatures especially in the northern and central regions, which increases construction, and routine and emergency maintenance costs; and

I) About 47 percent of the population live in the eastern region, where population density rises in places to over 100 persons per square kilometer. The north contains about 28 percent of the population, the south 14 percent and the west 11 percent all with much lower densities. 
(iv) the difficulties in navigating rivers and streams, which precludes using this low-cost means of transportation.

7.15 International transport to and from Afghanistan is also affected by:

(1) the country's remoteness from the principal markets;

(11) 1ts land-locked situation which necessitates frequent transshipments to arrive at the final destination, with long and unpredictable transit times, excessive loss and breakage and, therefore, high credit costs and insurance premiums;

(11) the dependence of 1ts international routes on political, transport, and other conditions in nelghboring countries;

(iv) the absence of mrestricted access to the sea which causes long clearlng times because Afghan cargo in neighboring countries" ports normally receives lower priority than national cargo.

7.16 The success of the development strategy must be measured by the extent to which $1 t$ can come to terms with these geographic and physical constrai. ts on the nation's development. During the First and Second FiveTear Plans, 1957-66, the top priority was ending Afghanistan's geographical fsolation and integrating the regions of the country. About Af 15 billion (including forelgn assistance) were spent during the two Plans, which comprised 42 percent of total development expenditures. The most important 1inks were the Kabul-Kandahar-Herat highway, the Salang route to the north, and the routes to Jalalabad, Spln Boldak (Pakistan Railhead) and Islam Qala (Iranian border).

7.17 During the Third and Fourth Plans (1967-73), transport was supposed to play a much smaller role, receiving only 15 percent and 10 percent of planned expenditures. Within this reduced allocation there were also significant shifts in allocations. Expenditure on highway improvements and maintenance increased to 21 percent of total highway expenditures by the end of the Third Plan, and were to increase to 47 percent during the Fourth Plan. Total highway construction expenditures during the Third Plan amounted to Af 2.9 billion, or an average of Af 0.58 billion per year. The shift away from new construction reflected increased Government emphasis on protecting the considerable investments made earlier in the highway system and seemed to be a change in the right direction.

7.18 The First Seven-Year Plan envisions a masive increase in investment in transport infrastructure. The Transport and Communication Sector has the second highest allocation of funds - Af 55 billion or 32 percent of planned expenditures. Of this, about Af 40.5 billion is envisioned for the construction of a $1810 \mathrm{~km}$ railway linking Kabul with Iran and Pakistan. The project is to be completed in the following Plan period. The railway is to follow the clrcular trunk road. A loan from Iran is expected to finance the project. Although a pre-feasibility study has suggested that the project is justified, in the view of the World Bank the project is highly questionable. It will be 
difficult to demonstrate that the railroad could attract enough traffic to justify the big investment required to build and operate a raflroad line in such a difficult terrain. The pre-feasibility study which was not available to World Bank staff at the time of preparation of this Report, argues that the Vlability of the project does not rest on the feasibility of the Hajigak iron ore project. Previous proposals had always put it in that context. The iron ore deposit has a very difficult access and will require about $200 \mathrm{~km}$ of ra1l branch line to connect with the main ine. The construction and operation of a railroad line demands the support of a good organlzation and the participat1on of many skilled technicians and workers. For a country with no previous experlence in railroad operations, with a shortage of skilled people and with serlous institutional problems in almost every area, the task of running a railroad efficiently wil be extremely demanding. A difficult technical problem w11 be the selection of the appropriate gauge. The country's main international land routes via the USSR, Pakistan and Iran, utilize the respective national railroad lines which each have different gauges (see para. 7.05 above). If Iran finances the project, presumably their gauge would be the one finally selected, but due to congestion in Iranian ports only 10 percent of Afghanistan's international traffic is presently using this route. For the rest, additional transfer costs would be required.

7.19 Approximately Af 10 billion is allocated to for highway construction, about 6 percent of total planned expenditures. Merchandise transport is projected to double during the Plan period, and passenger transport to rise almost sixteenfold. The network of improved roads 1 s to be increased from 9,200 to $11,000 \mathrm{~km}$, and the network of paved roads from 2,600 to $3,700 \mathrm{~km}$. The density of Afghanistan's primary road network 1 s reasonable and adequate to serve the principal regions of the country, but the system of the secondary and tertiary roads still has a long way to go before it meets the needs of the country's development. Improvement and proper maintenance are the main needs of the primary road network, while a more adequate construction program should be devised for secondary and tertiary roads. It is these secondary and tertiary roads that are crifical to the development process. They open up new, previously inaccessible, regions and permit access to outside health services, schools and markets. Access to markets is critical to the economic developDent of tural Afghanistan, for although from half to two-thirds of all agricultural produce is currently consumed on location, this is undoubtedly in part the consequence of very poor or non-extstent transport facilities. If farmers have access to markets, there is incentive for them both to increase production and to make use of the modern inputs that wil enable them to do so. There is a great need to increase emphasis on tertiary roads yet the Plan envisions less than $2,400 \mathrm{~km}$ of such roads, only slightly more than the length of primary and secondary roads to be constructed. From a purely economic point of view, it would seem that, in general, secondary and tertiary roads should be built to low standards. High construction costs and low volumes of traffic preclude the justification of higher standards for secondary and tertlary roads. Perhaps, the best course to follow would be to carry out small 1mprovements with maintenance forces in most of the secondary and tertiary road network rather than undertake a complete improvement of selected roads. 
7.20 It is in this light that the maintenance expenditures in the Plan must be assessed. About Af 1.8 billion has been allocated for highway maintenance. The projections show a substantial decline in total annual allocation for this purpose from 1980. After that date allocations would be insuffictent to maintain the road network according to sound engineering and transport standards. Government officials indicate that the decline is due to the intention of cransferring allocations for highway maintenance from the development to the ordinary budget and to the absence of foreign ald commitments for this purpose from 1980 onwards. The procedure of leaving these amounts out of the Plan projections is highly unsatisfactory given the priority wich ought to attach to maintenance, and which it is unlikely to receive as part of the ordinary budget.

7.21 With regard to international transit a significant step has been taken through the establishment of an international truck company for operations with Europe. Truck transport costs will probably be higher than the present transportation of goods by multiple modes, but trucks will substantially shorten transit time, provide firmer delivery dates, reduce loss and spoilage and consequently reduce credit costs and insurance premiums. Afghanistan has recently signed the T.I.R. Convention, and the truck company would operate under agreements of that Convention. The Company was formed at the end of April 1977, and consists of a joint venture between the Government and a subsidiary of Dutch Railways. The Government has a 51 percent participation in the company which was financed by the Dutch Government. Inftially the company's fleet consists of ten 20-ton trucks, and operations started in mid-1977. Six weeks is the time estimated for a truck round trip to Europe as compared with several months on the present multi-modal routes.

7.22 Ait transport has an allocation of Af 1.1 billion in the SevenYear Plan for construction and naintenance. This is roughly four times the amount allocated in the previous seven-year period. About 50 percent of the allocation is foreign aid, and the main project is the construction of a new airport at Logar, some $47 \mathrm{~km}$ to the south of Kabul, at an estimated total cost of $\$ 55$ milition. A feasibility study was presented by consultants in June 1975. Kabul airport has Ifmted potential as it cannot meet safety standards for wide-bodied jets due to its location. It $w_{2} 12$ be a matter of profecting the growth in traffic, particularly of tourist arrivals, before a decision can be made on the need for this investment at this time.

\section{(iv) Transport Market and the Vehicle Fleet}

7.23 The nature of the transport market currently and in the foreseeable future is of crucial significance to the overall transportation sector strategy that Afghanistan should pursue. Statistical information on transport demand is insufficlent and sometimes contradictory. The main sources of information are annual road traffic counts performed by the Ministry of Public Works, toll station data, airport and port traffic statistics, and special traffic studies conducted by consultants for specific projects. With respect to road traffic, a country-wlde origin-destination survey was carried out in July-August 1970 by RCMD with the assistance of consultants. This survey has not been updated since. 


\section{EDUCAIION AND MANPOWER}

8.01 The education sector is a major participant in both the economic and social development of Afghanistan. Education plays a significant role in providing (a) productive skills at the different levels and for different sectors, that are necessary for the implementation of the development plans in agriculture, industry, health etc., (b) training in the maintenance of natural resources and physical infrastructure necessary for rural and urban development, (c) knowledge and skills to cope with the demands of development, such as written communication, banking, taxes, bureacracy and operating machinery, and (d) cralning for self-reliance in meeting basic needs in health, nutrition, civic participation and communication. This implies a broad approach to education in terms of both objectives and base, whereby ultimately all sections of the population must receive, within the constraints of resources, an adequate education to enable them to participate in the development process both as productive workers and as effective citizens.

\section{A. Development of the Education Sector}

8.02 The formal educational system in Afghanistan was born in 1903 with the establishment of the first official school, Habibia, in Kabul. Prior to that, education was limited to the religious schools in which instruction was provided by the religious leaders (Mullahs) by methods of memorization and recitation. The curriculum was limited to reading the Koran and, at a later stage, some Dari language study. Students who wanted to pursue their religious education to become mullahs had to study further Arabic texts of the "Shariat" or Islamic law. The mosque school only used to run for the winter months when there was no farm work, and classes were held early in the morning and in the afternoon after prayers for a duration of 60 to 90 minutes. Because of the small number of students pursuing this kind of education and the informality of instruction, illiteracy was widespread.

8.03 In 1907, four years after the first official school was opened, a Council of Public Instruction was established to broaden and modernize the curriculum of the traditional schools. As a result, the primary school syllabus included reading, calligraphy, fundamentals of Islam and mathematics, In the 1920's the number of government schools increased to 13, all in Kabul, and the first Minister of Education was appointed. In 1931 the new constitution made primary education compulsory but by 1932 total enrollment in all government schools was only 1350 pupils. By 1940 government schools had increased to 324 with an estimated enrollment of 60,000 . That year the school curriculum was revised and Pashtu became the sole language of instruction until 1946, when Dari was allowed to be taught as a second language and later as a medium of instruction in Dari language regions.

8.04 Since 1957 educational development in Afghanistan has been consciously associated with the overall development of the country. Attempts were made to plan the growth of the educational system in harmony with the other sectors of the economy in the course of drawing up the four five-year 
plans for implementation between $1957 / 58$ and 1976/77. In addition to quantitative targets, the plans reflected concern for balance, quality and ranpower needs. The First Five-Year Plan (1957/58 - 1961/62) stressed the supply of skilled manpower particularly as $1 t$ related to rural development. Specific features of the plan included (a) a significant increase in the number of village schools, (b) introduction of manual trades and gardening into primary schools, (c) an increase in secondary school exrollment, (d) establishment of an agricultural-vocational training school and additional teacher-training and technical vocational institutions, and (e) initiation of an adult education program. The Second Five-Year Plan $(1962 / 63$ - 1966/67) de-emphasized primary education and village schools and stressed the development of high-level manpower by projecting a 130 percent increase in secondary school enrollment, and by expanding existing technical insticutions and establishing new ones. In the Third Five-Year Plan $(1967 / 68$ - 1971/72) the question of "balance" was raised. It was pointed out in the introduction to the education chapter that "the objectives of a modern society are not restricted to the attainment of economic targets, but also include the achievement of political and social goals." Accordingly manpower considerations had to be balanced between one part of the country and another and a balance of enrollment between one level and another had to be achieved. Expansion of primary education was planned in parallel with expansion in secondary education and new educational institutions were proposed for the less developed provinces. In addition the plan stressed qualitative improvement of the educational system in terms of completion of school buildings, provision of teaching materials, reform of curriculum, and modernization of teacher education. The same issue of "balance" was the focus of the Fourth Five-Year Plan $(1972 / 73$ * 1976/77) but more in connection with educational levels than with geo-demographic considerations. The major concerns of the plan were to strike a plausible balance between the expansion rates of the different educational levels, to halt the decline in the quality of education as a resuit of the over-ambitious expansion of secondary education, and to reduce illiteracy by spreading basic education.

8.05 When the degree of 1mplementation of the targets of the plans was reviewed by a UNESCO mission, (Report EFM/65, January 1974) the following conclusions were reached:

(a) Balance between educational levels. There was a remarkable growth of post-primary level education relative to primary level. While the targets for both levels in the plans were exceeded, the margin was far larger for secondary education than for primary education. The extent of fulfillment of plan enrollment targets for the primary level was 95 percent for the first Plan, 116 percent for the second and 102 percent for the third, while the corresponding fulfillment for the secondary level was 124 percent, 138 percent and 182 percent, respectively.

(b) Geo-demographic balance. Inequality in primary level enrollment among provinces declined by 9 percent and in secondary level by 34 percent, during the Third Plan. 
(c) Quality. Quality up to the beginning of the Fourth Plan had "almost certainly" declined. This was reflected in the comparative rates of growth of enrollment and educational development expenditure. In constant prices, the Government invested 64 percent less in buildings and equipment per extra student in the third Plan than in the first. This affected the quality of certain key areas of instruction such as science and handicrafts.

(d) Manpower needs. The order of importance of the types of specialized training as revealed by enrollment, with agriculture at the bottom, was "doubtfully in true proportion to the development requirements of the country's largely agricultural economy."

8.06 Quantitative development of the educational system over a ten-year period from 1964/65 to 1974/75, (See Volume II, Table 12,1) indicates a clear bias in enrollment growth towards the secondary level? While the enrollment at the primary level doubled, the corresponding enrollment increased by five times at the middle secondary level and by twelve times at the upper secondary level. This led to a change in ratios between the three levels from $68: 5: 1$ to 12:2:1 Enroliment in vocationat edotation fell from 8.5 percent of total secondary enrolfment in $1966 / 67$ to 2.6 percent in 1974/75;. During the same period, the proportion of female enrollment remained constant at the primary level ( 15 percent) but fell from 20 percent to 12 percent at the middle secondary level and from 24 percent to 11 percent at the upper secondary level, but increased from 8 percent to 13 percent in vocational schools.

\section{B. The Present System}

\section{(i) The Organization of the System}

8.07 The Government controls and administers all formal educational and training institutions and non-formal education schemes. The Ministry of Education is responsible for formal schooling from kindergarten through upper secondary. Private schooling represents only about 0,2 percent of primary and 2.3 per ant of secondary enrollment. The Ministry of Education is organized under the Minister and two deputy Ministers into 13 presidencies and 5 general directorates, as shown in Volume II, Chart 12.1. Higher education is controlled and administered by the newly established Ministry of Higher Education. While the functional relationships between the two Ministries are being worked out, one of the first tangible outcomes is the transfer of the responsibility of pre-service teacher training to the Ministry of Higher Education while certain aspects of in-service training remain with the Ministry of Education. Similarly vocational and technical education is divided between the two Ministries depending on the level of training. Education is managed at the provincial level by Provincial Directorates of Education each headed by a Director and assisted by at least 3 inspectors and a supporting staff.

8.08 Until 1975 the educational system comprised a six-year primary cycle, a three-year middle secondary and a three-year upper secondary, and up to six years of higher education. These levels have been restructured under 
the 1975 educational reform into kindergarten ( 1 or 2 grades), primary ( 8 grades), secondary ( 4 grades) and higher ( 2 - 6 grades). The structure of the educational system is shown in Volume II Chart 12.2

8.09 The school year is phased differently for cold (March - December) and warm (September - May) weather areas of the country. The school year is about 214 working days of which 10-15 percent is spent on an elaborate system of school examinations. Most of the urban schools at all levels operate on a double shift basis.

8.10 The two official languages of instruction are Dari and Pashtu. When one. is the medium of instruction, depending on the language of the majority of pupils, the other is introduced as a second language in Grade 4. A foreign language (normally English) is introduced in Grade 6. The distribution of students between Dari and Pashtu at the successive levels is about 65 percent and 35 percent at the primary level, 60 percent and 40 percent at the middle secondary level and 55 percent and 45 percent at the upper secondary level. of the students using Dari as a medium of instruction about 18 percent are females, while of those using Pashtu only 2.5 percent are females.

\section{(1i) Primary Education}

8.11 There are two types of schools at the primary level: the "village" school and the "primary" school. While the regular primary schools function on the basis of one grade - one classroom - one teacher, the village schools are mult1-graded. A one-teacher village school has the first three grades. When a fourth grade is added, it is promoted to a two-teacher school, and when further primary grades are added it is transferred into a three-teacher school. There are, however, some schools with fewer teachers than this formula allows. The Ministry of Education does not undertake to provide a building or to rent one for a village school. Most of the village schools are small and exist in communities where the population did not justify a full six-class primary school. In 1974 there were about 654,000 pupils at the primary level (78 percent of the enrollment of the whole formal system) of whom 21 percent were in village schools. The numbers of primary level schools, reachers and enrollments appear in Table 34 below. The intent of the government is to extend all village and primary schools through the etghth grade. In 1975, 308 village and primary schools througnout the country were extended to eight grades. 
TabIe 34: PRIMARY LEVEL SCHOOLS, 1974

\begin{tabular}{lrcr}
\hline Iype & Schools & Teachers /a & Pupils \\
\hline Village & 1,905 & 2,742 & 136,854 \\
One-Teacher & 1,380 & 1,380 & 77,456 \\
Two-Teachers & 143 & 279 & 13,453 \\
Three-Teachers & 382 & 1,083 & 45,945 \\
Primary & $\underline{1,468}$ & $\underline{14,873}$ & $\underline{517,355}$ \\
Total & 3,373 & 17,615 & 654,209 \\
\hline
\end{tabular}

la Teachers are actual numbers. Some positions in two- and three-teacher village schools are unfilled.

8.12 Primary school enrollment in 1974 represented about 30 percent of the total age groug. The male enrollment represented 51.2 percent and the female enroliment only 8.6 percent) of the corresponding age groups. In other words more than half a millfon boys and one million girls, age 7-12, were not in primary level schools (including village schools). The average pupilteacher ratio was 50 in the village schools (56 in the one-teacher schools), and 35 in the primary schools. The distribution of teachers according to their qualifications appears in Volume II Table 12.14. About 60 percent of primary school teachers have professional qualifications while only about 43 percent of village school teachers have similar qualifications. Women constitute 18.3 percent of the total primary level teaching force, but only 2.3 percent of the village school teaching staff.

8.13 Since 1967 a team from Columbia University Teachers College with Afghan counterparts has been developing the content of the primary school curriculum and producing materials in an elaborate system of curriculum deve1opment. After a set of national goals and objectives was approved in 1970, a sthedule of subjects was set including language arts (language, social studies and science), mathematics, physical education, art and crafts, and religion, for Grades 1-3, with the addition of social studies, science, practical work, health and a second language in Grades 4-6. For each of these subjects the scope and sequence of the course is developed, for review by an academic council. Then books are written, tried out for one year and revised. Once approved by a review committee they are typed in final form and distributed free to schools to be used for 2 to 3 years. So far, textbooks for Grades 1-3 have been printed and distributed. After the government's decision to introduce practical subjects into Grades 7 and 8 the curriculum team has been asked to develop materials for about 50 vocational courses in a period of $1-2$ years. The implementation of the curriculum is faced with a number of problems. First, the printing facilities are inadequate and the distribution techniques cannot cope with the volume of the materials. Secondly, the teachers are not trained for the new curriculum and the coordination with the ongoing inservice training programs is not adequate. There are workshops 
conducted by the curriculum team for inspectors, provincial supervisors and headmasters who in turn will train teachers, but it is doubtful given the infrequency and short duration of these workshops that they will have any significant effect. Thirdly, the innovations in curriculum, particularly in science and practical work, are not coupled with the provision of sufficient instructional materials, which, added to the lack of teacher training, leaves instruction theoretical, teacher-centered and didactic. Fourthly, most of the school buildings are unsuitable and were not designed as schools. Prior to 1975 only 3 percent of the village school bulldings and 18 percent of the primary school buildings were owned by the Ministry; in an additional 7 percent and 3 percent of cases, respectively, there were no buildings at all; and the remaining schools were housed in mosques, converted houses and stores. Since 1975 a major school-building program has been launched, but the backlog is so large that it will take decades before adequate facilities are available.

\section{(11i) Secondary Education (General)}

8.14 Secondary education has been provided by middle schools (grades 7-9) and full secondary schools which combine middle and lycee schools (grades 7-12). The present trend, after the educational reform of 1976 and the extension of primary education through grade 8 , is to have one type of general secondary school covering grades $9-12$. In 1974 there were 323 independent middle schools, 195 full secondary schools and 1 independent lycee in Kabul city. Enrollment was about 112,000 at the middle level, and 56,000 at the upper level. The enrollment ratios presented in Table 35 below indicate the heavy bias in favor of the male population.

\section{Iable 35: SECONDARY LEVEL ENROLLMENT $1974^{\circ}$}

Enrollment $\%$ of age group

\begin{tabular}{crr} 
Mtddle Level & & \\
Male & 97,916 & 21.0 \\
Female & 13,773 & 3.0 \\
Total & 111,689 & 12.0 \\
Lycee Level & & \\
\hline Male & 49,686 & 11.9 \\
Female & 6,022 & $1.4^{\prime}$ \\
Total & 55,708 & 6.7
\end{tabular}

8.15 In 1974 , there were 2,424 teachers in the independent middle schools and 4,752 in the full secondary schools, leading to a low average studentteacher ratio of $16: 1$. The distribution of reachers according to their qualifications is given in Volume II, Table 12.15. There is considerable 28,6 vation in the distribution between the two types of schools. While only 28.6 percent of teachers of middle schools have post-secondary education, about 48 percent have a similar qualification in the full secondary schools. It 18 also worth noting that 5 percent of middle school teachers have received 
no more than a middle-school education, and 20 percent of the full secondary school teachers no more than general secondary-level education. Wome 3 constitute 3 percent of the total number of middle schoal teachers and 17.5 percent of full secondary teachers. Most of the women teachers are in Kabul ciley.

8.16 Prior to 1976, specialization into social science and natural science streams occurred only in Grade 12. With the elimination of the middle schools, such specialization will extend from Grades 10 to 12 , where science students will study science subjects 55 percent of the time and art students will devote 15 percent of the time to science. However few schools have ary equipment or facilities for actually implementing courses in these areas, and teaching fheneral is restricted to the lecture-recitation method.

\section{(iv) Secondary Vocational and Technical Education}

8.17 Vocational and technical education is provided by 15 institutions (Volume II, Table 12.16) with an enrollment of about 7500 (1974). This , represents less than 1 percent of the secondary level age group and 3 percent of secondary level enrollment. Enrollment of girls is about 13 percent, of the total, and is limited to two institutions. Enrollments by type of institution are shown in Table 36 below.

\section{Table 36: ENROLLMENT IN VOCATIONAL SECONDARY SCHOOLS, 1974}

\begin{tabular}{lc}
\hline Iype of Institution & Enrollment \\
\hline & \\
Technical & 948 \\
Mechanical and Craft & 1,149 \\
Agricultural & 743 \\
Commerce and Management & 1,278 \\
Other Vocational & 369 \\
$\quad$ Total & 4,487 \\
\hline
\end{tabular}

Note: Detailed data in Volume II, TabIe I2, I6.

8.18 Technical trafning is avallable at three institutions (Volume II, Table 12.3); the Afghan Institute of Technology (A.I.T.), Jangalak Technicum and $\mathrm{Ba}$ lkh Technicum. The A.I.T, which was established in 1951, offers specialization in electricity and electronics, civil engineering, building construction, automotive mechanics, aviation mechanics, and machine tools. Although half of the time is designated for practical wor $\mathbb{R}^{3}$, this is reduced

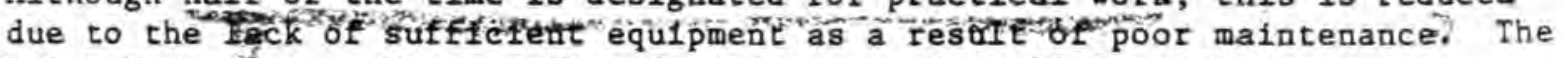
Balkh Iechnicum at Mazar-1-Sharif, which opened in 1971, offers cnurses related to the oil industry and the Jangalak Technicum, opened in 1974, offers courses in electromechanical fields. Skilled workers are trained in three Mechanical Schools at Kabul, Pakhtia and Kandahar. Courses are available as follows: Kabul: Radio, electrical power, automobile mechanics, building trades, mechanical trades; Pakhtia: Mechanical, electrical and automotive 
trades, carpentry; Kandahar: Automotive, and mechanical trades. There are also craft schools that provide training in carpentry, building construction, weaving, press art and printing, ceramics and art, and talloring.

8.19 Agricultural education is taught at only 3 agricultural secondary schools (grades 10-12): Baghlan, Lashkar Gah and Farah; enrollments total about 750 pupils. Entrance is based on achievement in the primary schoolleaving examination and on avallability of boarding places. Dropout rates average 32 percent over the three-year cycle. General subjects occupy about two-thirds of the curriculum; about five hours per week are spent in poorly equipped practical laboratories. An almost complete lack of agricultural texts in Dari or Pashtu hinders instruction. School farms are underutilized and little time is allocated for practical farm work in the course timetable. A project is presently under way in which the present schools are being expanded, remodelled and equipped, and 4 new schools are being constructed. Some classes in the latter schools are already in session. A new curriculum will be implemented which represents a major improvement over the existing one. Fifty-five percent of available time will be devoted to agricultural subjects compared with 33 percent in the old curriculum. The new curriculum provides for a common core of agricultural subjects in the first two years and for subject options in the final two years which include agricultural extension and cooperatives, crop production, livestock, and farm mechanics. Each school will be provided with a school farm of 100 to 150 acres and about 66 percent of agricultural teaching time over the four years will be practical work on the farm, compared to less than 10 percent in the existing course.

8.20 Commercial and management education is provided by the Commerce Lycee, the Public Administration Lycee, and the Republican lycee which is the girl's commerce Lycee and runs courses simflar to it, with the addition of weaving, home economics and hygiene. The Ministry of Education runs a small Hotel Management School for hotel workers and tourist guides in a rented building. The Ministry also runs a Music School and a Physical Education School (Volume II, Table 12.16),

8.21 In 1974 , there were 464 teachers in the vocational and technical seconisty schools (Volume II, Table 12.17), resulting in a low pupil/teacher ratio ranging between $6.4: 1$ and $16.2: 1$. Less than 25 percent of the teachers had university degrees and the rest had an education equivalent to the level they were teaching in. In addition most teachers are not trained in pedagogy and practical activities, consequently equipment is hardly used and instruction is highly didactic.

\section{(v) Other Formal Iraining Programs}

8.22 A number of Government Ministries run training institutions to meet their particular needs. Among these are the Telecommunications School which offers technician courses in radio, telegraphy and carrier telephones for the Ministry of Communications, Afghan Air Authority and Radio Afghanistan. The Ministry of Defense runs the Military Engineering and Ordinance College in Kabul. 
8.23 A number of agriculture training institutions established several years ago (Animal Health and Production Institute; Project on Agricultural Credit and Related Service through Cooperatives in Afghanistan (PACCA) Iraining Institute) have been merged recently with the Institute of Higher Agricultural Studies (IHAS). The Institute has an enrollment of about 200 students in three areas: veterinary science, credit/cooperatives, and forestry. Entrance is highly competitive but the drop-out rate is also high ( 38 percent). The curriculum spans five semesters with about one semester devoted to field work. The physical facilities are very inadequate with no equipment or farm laboratory land available.

8.24 The Ministry of Public Health has five training institutions to meet 1ts own manpower needs: (a) School of Nursing with an enrollment of 320 students and an average annual output of about 50 graduates; (b) Higher Institute for Assistant Pharmacists with about 50 students enrolled in a two-year course; (c) Higher Institute of Technology offering a two-year course with an entollment of about 40 students; and (d) Institute for Dental Medicine with an enrollment of 30 students. These institutions are staffed by 54 trainers including doctors, pharmacists, technicians and medical workers.

\section{(vi) Informal Irafning Activities}

8.25 Government ministries and state enterprises organize, on an ad hoc basis small training schemes for their own employees. Departments in the Ministry of Agriculture, for instance, have offered in past years short training courses in the fields of irrigation, forestry, animal diseases, animal care, audiovisual techniques, fruit and vegetables, cocoon raising and beekeeping. The Paktia Development Program is an example of the provision of informal training for immediate needs. The Program includes a project for the development of small industries and handicrafts, which although it is production-oriented offers training opportunities in crafts. In addition, the Paktia Deyelopment Authority has trained farmers' guides and organized meetings on modern methods of agriculture and forestry.

\section{(vi1) Teacher Iraining}

8.26 There are nine institutions for teacher training, eight primary teacher training institutes (DMA's) and one Higher Training College (HTC). Preservice training of primary teachers (Grades 1-8) is provided in a one-year course at grade 13 level at the DMA's and the training of secondary school teachers is offered at Grades 14 and 15 at the HIC and some DMA's (see Volume II, Iable E3). Both courses cover academic and professional studies. Provi- sion is made in the two-year course for specialization in one of the following streams: Mathematics/Physics; Chemistry/Biology; Dari/English; Pashtu/English; and History/Geography. In the new reform, primary teacher training will be of two years duration in Grade 13 and 14 while secondary teacher training will be of four years duration from Grades 13 to 16. A preinvestment study has been proposed for the construction of five new regional teacher institutes with a total capacity of 2400 places. 
8.27 Inservice training is provided in the same institutions either as a parallel program (Grades 13-15) for teachers who have completed Grade 12, or as an upgrading program (Grades 10-12) for those who lack academic qualifications. The upgrading program is a combination of professional courses given at the DMA's and regular academic subjects given at the Lycees. In 1975 there were 1232 students enrolled in the preservice program and 2801 in the fnservice courses (Volume II, Table 12.3). The proportions of women in the two programs were 3.6 percent and 31.7 percent, respectively.

8.28 The teacher training institutes have adequate accommodation facilities for about 1,000 men in total. The educational facilities, however, are popr, equipment is minimal and what is available lacks maintenance. The institutes are not equipped for training in manual or traditional crafts or agriculture. The curricula are now being revised to place more emphasis on these subjects in accordance with the shift in emphasis in the curriculum of Grades 7 and 8 . Practice teaching is conducted in laboratory and regular cooperating schools in the vicinity of the institutes.

8.29 Most of the teachers at the training institutes are university graduates about half of whom had their professional training at the Academy for Teacher Educators in Kabul (Volume II, Table 12.3). The Academy provides a nine-mot: th course at the 17 th $\mathrm{grade}$ level in elements of educational psychology, methodology, tests aud measurements, and special methods of teaching. It is presently housed in old residential premises with inadequate equipment. A pre-investment study is to be undertaken for the design of a new complex to house the Academy with the HTC and DMA of Kabul.

8.30 Training of vocational and technical school teachers is provided at the university level. The Faculty of Engineering has a limited program for the preparation of teachers for technicums and mechanical and craft schools. The faculty of Agriculture has a special department to prepare teachers for the agricultural secondary schools. The Ministry of Education, In collaboration with the Ministry of Agriculture is instituting a nine-month agricultural education program at IHAS with 40 percent of instruction time spent on secondary-level agricultural and adult education teaching methods, 30 percent on technical-practical agricultural instruction and 30 percent on development of instructional materials. In addition, 40 fellowships to the U.K. will be available for training in technical education.

\section{(viii) Educational Materials and Services}

8.31 The Education Press, within the Ministry of Education, is the only printing facility (government or private), which has the equipment and expertise to print textbooks and teaching materials in Dari and Pashtu. The present need is for an annual production of over three million books, which will increase to about eight million by 1982. Nearly 40 of the technical staff of 190 have received regional training fellowships in Tehran, two have been trained in Germany and the remainder were trained on the job. The inadequate storage and operational space makes assembly-line procedures inefficient. Most of the machinery is more than 20 years old and insufficient to print the volume and varrety of matérial required. Bindery facilities are virtually 
non-existent, and reliance on manual labor has created a backlog of nearly two million volumes. Paper supply, storage and control need to be improved. Lack of storage, complicated recording procedures and inadequate distribution facilities, both in Kabul and regionally, hamper distribution of completed materials. A project financed by the Canadian Government will be directed at upgrading the present facilities.

\subsection{The Educational Broadcasting Center produces two half-hour broad-} casts (in Pashtu and Dari), per week to assist primary school teachers. A staff of 17 qualified teachers develops scripts and prepares prerecorded broadcasts. The Center is faced with the need to take a number of actions to overcome the many problems it faces. These include improved reception in some areas, repairs to many of the 1,200 school receivers, effective liaison between curriculum writers and broadcasters, easing of budgetary constraints, increasing radio time through Radio Afghanistan and the development of a dynamic, long-range plan for school broadcasting. The present accommodation in residential buildings lacks adequate heating while technical equipment is barely sufficient to meet the present output.

\subsection{The Audio-visual Production Center, with a total staff of about} 60 teachers and an annul budget of over Af 2.7 million, operates in inadequate, unsuitable and condemed buildings. The photography section produces black and white filmstrips and slides, distributes materials from its library and repairs radio and projection equipment. The work of the production unit includes making science kits, mathematics kits, blackboards, chalk and social studies maps. Improved coordination is needed between the curriculum developers and the production workers. Evaluation of the classroom use of such materials is essential, as is the need to expand and link the operations of the Center with other service units and teacher training facilities.

8.34 The Science Center revises rextbooks, conducts workshops as part of in-service teacher training programs, and produces science and mathematics kits for both teacher demonstration and pupil use in secondary schools. During 1975, revistons were made to textbooks in arithmetic, physics and biology at four grade levels. Over 500 teachers were enrolled in 12 inservice training workshops, only two of which were held in Kabul. The Center has produced and distributed nearly 150 science and mathematics kits to all provinces. Accommodation is extremely limited in small, unsuitable buildings. Mechanical equipment is meager, with the result that output is improvised and often roughly finished. Kits are made from scrap metal and wood, with the intention that they can be reproduced by innovative teachers in the schools.

\section{(1x) The University of Kabul}

8.35 The University of Kabul has an enrollment of about 12,000 students 10 percent of whom are women. In addition to free tultion al students receive a monthly allowance of about Af 250 and about 7,000 students are boarders (boarding is free for those from out of Kabul). The intake and output of the faculties of the University are shown in Volume II, Table 12.4. The growth in enrollment has been fastest in the Faculty of Engineering (from an intake of 250 in 1976 to 1053 in 1977). Degree courses are of four years 
duration, except in the Faculty of Engineering and the Polytechnic where they are five years and in the Faculty of Medicine where they are six years. Courses are organized on semester basis. Dari is the main language of instruction though fluency in Pashtu is also required of teachers and students and other languages are used in 1ndividual faculties according to their affiliation with bilaterial aid agencies (1.e. English in the USAID-assisted faculty of Engineeri.ng, Russian in the USSR-assisted Polytechnic, German in the FRG-assisted Faculty of Economics).

8.36 Admission to the Unfversity is on the basis of a competitive examination. Candidates are then assigned to the different faculties on the basis of their grades. Places for each faculty are determined by the Ministry of Planning, In $1977,3,369$ students were admitted while the total number of secondary level graduates was about 15,000. The University is well provided with physical facilities but there are not enough dormitories. While the older faculties are well equipped, the new faculties like veterinary science lack the necessary equipment. Of the teaching staff of 758 , 15 percent hold $\mathrm{Ph} . \mathrm{D}^{\prime} \mathrm{s}$ while 35 percent have Master's degrees and 50 percent Bachelor's degrees.

\section{(x) Non-Formal Education}

8.37 Adult education and literacy programs are directed by the National Directorate of Adult Education. Programming in terms of planning, curriculum and materials development, and training for field operation is done at the central level while the non-formal education activities are administered locally by provincial directorates. The programs are presently addressed to four priority groups: (a) farmers; (b) cooperative members; (c) women; and (d) new urban residents who due to migration from rural areas face problems of adjustment. The first two programs are of six months' duration and the last two of nine months duration. Each program starts with a literacy part consisting of 25-30 sequences that require 300-350 hrs. On top of this is built a functional education program that varies with the different target populations. There are presently about 13,700 male learners grouped in 639 sections and about 900 women in 37 sections in six provinces, Classes are taught by fulltime instructors with secondary level education. The Government plans to extend these $30 t 1 v i t i e s$ to all provinces and by 1283 have an enroliment of 60,000 men and 12,000 women in 4,600 groups. At the same time the Afghan Women's Welfare Soclety, a semi-autonomous organization responsible directly to the Minister of Education, undertakes training and literacy activities for adult women, and conducts vocational courses in social services, home economics and secretarial skills.

\section{(xi) Education Finance}

8.38 Total Government financing (ordinary and developzent) of the Ministry of Education and Kabul University increased from Af 931 million in $1971 / 72$ to Af 2371 million in $1977 / 78$, a nearly 1.55 percent increase in monetary terms. The proportion of the total Government ordinary budget spent on education has ranged between 15 and 18 percent during this period. At the same time the proportion of the total development budget allocated to education has steadily 
increased from - 1.7 percent in $1971 / 72$ to 3.3 percent in $1975 / 76$ and 5.5 percent in 1977/78. The proportion of GNP devoted to education, is less than 2 percent which puts Afghantstan in the fower qualtite of fevetoping countries. The proportions of expenditure devoted to primary, secondary, vocational and higher education appear in Table 37 below.

Table 37: BUDGET ALLOCATIONS TO EDUCATION 1971/72 TO 1977/78

(in percentage)

\begin{tabular}{lcr}
\hline Level & Recurrent & Development \\
\hline Primary & 37 & $42 ;$ \\
Secondary & 24 & 7 \\
Vocational & 14 & 12 \\
Higher 5 & 16 & $39 ;$ \\
\hline
\end{tabular}

The difference in proportions between the two types of budgets is accounted for by the rapid expansion in primary school construction and the ongoing construction program at Kabul University.

\section{Major Issues in the Educational System}

8.39 In spite of the high degree of fulfiliment of the quantitative targets of previous plans, and the numerous attempts at qualitative improvements, the present system of education and training is still faced with serious issues and problems. Some of these issues are a result of previous strategies and other are inevitable consequences of the rapid quantitative expansion. The major issues are in the following areas:

\section{(1) Planning and Management}

8.40 There, are four major issues in the administration of the educational system; (a) at the central fevel development responsibilities are fragmented. For instance, curriculum devefopment and implementation is cartied out by a number of departments with little coordination and synchronization. This has led to cases in which a new curriculum is implemented before the necessary textbobiks and aids are produced and thecéchérs reoriented; (b) Education planing is weak ovefalldue to the shortage of qualified staff and the low priority which is accorded to this function. Many of the other problems which are listed below have their roots in the inadequacy of educational planning; (c) while the data-collection function of the Department of Planning is well developed, the research function has never been actually activated, particularly in areas related to policy and decision making. Moreover, the status of the Department of Planning at equal level with other Departments prevents it from being effectivejumonjorjng implementation; (d) At the provincial level the educational administration structure is too weak eforfect dny

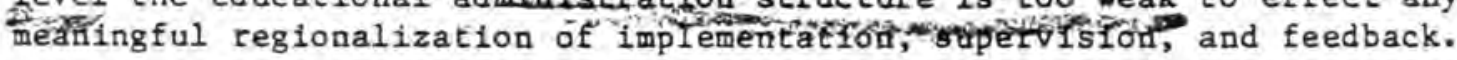




\section{(1i) Efficiency}

8.41 The efficiency of the educational system is very low. Dropout and repetition rates (See Vol. II, Table 12.5) are very high at the secondary level and after Grades 4 and 5, High dropout rates mean that a large amount of the ordinary budget is spent on those who fall to complete the1r present level, particularly those who drop out before the minimum for permanent literacy was achieved. Heavy dropout rates also contribute to under-utilization of available space, which is shown in the decrease in class size in successive grades within each cycle. The very high repetition rates mean that many students stay in school longer than the normal duration, thus depriving other children of access to education. On the basis of repetition rates per grade and the age-grade enrollment distribution (Vol. II, Chart 12.3) it can be seen that in 1974, more than 140,000 primary places, 32,000 lower secondary places and 13,000 upper secondary places were taken by laggard students. In other words, if it were not for the shortcomings in internal efficiency, the age-specific enrollment ratios at each educational level could be increased by about 20 percent with no additional physical facilities.

8.42 Repetition and dropout increase the cost per student. The calculated rates for Afghanistan roughly indicate that more than 15 pupil-years were invested per successful completer at the primar: level and not less than 20 student-years at the secondary level. In other words, due to internal inefficiency a high proportion of the ordinazy budget is wasted. A major reason for the high dropout and repetition rates is the examination system. The "free-answer" nature of the questions and the unstandardized scoring scheme, make these examinations subjective and of very little value for diagnostic or evaluative purposes. Since they are only used for promotion decisions, students, teachers and parents view them as an end and passing them justifies any technique used by the students to achieve the end. The system puts a great deal of power in the hands of teachers, who have tended to use it in a negative fashion to restrict the number of promotions. A system of automatic promotion for the first three grades was trieo earlier and abandoned within the context of a grade-oriented curriculum and evaluative examination. Other causes of dropouts and repetition are related to the low quality of educational methods and materials and unsuitability of the zurricuIum.

8.43 Many of the reasons for high dropout rates are external to the education system. Economic necessity often leads parents to withdraw their children from classes. These are very difficult problems to tackle. The Government has taken steps to permit children to assist their parents at harvest time through varying vacation dates. These are now at the discretion of provincial Governors and Directors of Education. Closer proximity of students to schools will also help, but here it should be noted that the proposal to consolidate primary schools will aggravate the problem. There are no easy answers to the question of how to reduce the drop out rate and increase overall enrollment. In order to find out it might be appropriate to select one or two provinces for intensive education development, with careful school mapping and the adoption of pilot schemes such as school-feeding, modified examination systems and possibly some experimental scholarship schemes directed at the very poorest groups. 


\section{(iii) Equity}

8.44 Educational entollment rates exhibit disparities by sex, region and urban/rural location. Custom and social pressure militate against the enrollment of girls. The female age-specific enrollment rate is 8.6 percent at the primary level, 3 percent at the lower secondary level and 1.4 percent at the upper secondary level. The variation in educational opportunities among provinces $1 \mathrm{~s}$ also high as seen from the representation indices in Vo1. II, Table 12.2. These differences 1ncrease with each successive cycle. The Government is focussing on the issue of regional disparities in education, and in future, projections of enrollment will be carried out by province. Rural areas also have lower quality of education in terms of availability of materials, trained teachers, and physical facilities. These factors have generally resulted in higher dropout and repetition rates for females and rural areas. A large part of the problem of increasing the enrollment of girls in the rural areas, is the shortage of women teachers. Provincial quotas have now been established at the Kabul BTC for women, but in the longer run tt will be necessary to have adequate facilities and dormitories at the provincial institutes. Only the institute at Balkh has a dormitory for girls. The proposal for an intensive education project in 8.43 above should include pilot programs to train women teachers and increase female enrollment.

\section{(iv) Productivity}

8.45 General secondary schools have tended to concentrate on educating students exclusively for University entrance, yet more than half of the students terminate and enter the labor market with little relevant preparation for work or adult life. The same applies to school leavers at the end of the primary level. Vocationalization of Grades 7 and 8 may have no 1mpact at all, unless a task-orlented curriculum is developed accompanied by provision of adequate equipment, facilities and teachers. School leavers at earlier stages lack not only skills but the minimum literacy level for retention.

8.46

The productivity of the training system has been low because firstly it presumes that the labor market is highly structured while only a small segment is. Secondly, it is assumed that most students trained in speczalized institutes cerminate their studies and join the labor market according to a manpower supply-demand scheme, while in practice large numbers of graduates of secondary technical and vocarfonal schools go on to further education. Thirdly, graduates of training institutes receive inadequate training in practical subjects and are thus ill-prepared for the labor market.

\section{(v) Quality}

8.47 The effectiveness of the educational process depends upon many factors including physical facilities, equipment and teaching materials, methods of reaching, examinations, and perhaps most importantiy, teachers. The existing system has weaknesses in all of these areas. According to the Seven-Year Plan (reflecting conditions in 1975) "2,342 schools, which form 69.5 percent of all schools, lack proper buildings which in view of the climatic conditions of the country, has been instrumental in the lowering of 
educational standards." More serious is the inadequate provision and distribution of equipment, textbooks and teaching materials, in spite of the active attempts of the Ministry of Education (paras, 8,29-8.32). The few laboratories which exist suffer from lack of maintenance and avallability of supplies. Consequently most of the classroom time is devoted to lecturing, reciting and notetaking.

8.48 A major weakness of the curriculum is that it is subject-oriented and designed from the top down with no flexibility to accommodate different community needs and target pupll populations. Similarly, the vocational and technical curricula are subject-matter materials rather than skill and taskoriented with a specialized mode of delivery and evaluation. Teacher qualifications have been inadequate both in terms of their formal levels of attainment and in professional training, (paras. 8.12, 8.15, 8.21). On-the-job professional help cannot be expected from supervisors who have a large number of schools to cover and who are not completely attuned to recent developments in education. The Government is avare of the deffciencies in the present curriculum and has taken some useful initial steps toward increasing the community orientation. These include a new emphasis on the reaching of hygiene, the use of local materials and methods, and the teaching of practical arts in grades 4-6. Obviously the constraints mentioned above of facilities and teaching skils, hamper these programs, but they do suggest that the thinking is along the right lines.

\section{Educational Policy and Strategy}

\section{(1) Characteristics}

8.49 The educational authorities have repeatedly expressed their awareness of the gravity of the problems and weaknesses in the educational system. In an attempt to solve these problems the Government drew up an educational policy which became the basis for the initiation of "The Education Reform" of 1975 and the strategy of educational development in the Seven-Year Plan. The basic objectives of the Education Reform are: $\underline{1}$ /

"a. To better the quantity and quality of education by means of reforming its structure and to create conditions fos its better organization and coordination.

b. To adopt manpower training (related to) requirements.

c. To prepare ground for the acquisition of permanent literacy during the period of primary education."

8.50 The strategy that was developed to achieve these objectives can be summarized as follows:

a. Primary education is extended from six to eight grades and is in principle considered compulsory and free. 
b. Practical subjects will be introduced into the curriculum of Grades 7 and 8 .

c. Promotion to the secondary cycle will be regulated by a competitive test. Those who do not pass it will form an important part of the labor force as unskilled literate workers or as skilled literates after a short-term special vocational course.

d. The two secondary cycles will be consolidated into a single cycle of 4 years, and the intake into the academic and vocational specializations will be balanced so that ultimately 50 percent of secondary education will be vocational.

e, The primary teacher training program will be extended from one to two years (post-secondary) and the secondary teacher training program from two to four years (post-secondary). Ultimately, the Government intends that primary school teachers should be holders of Bachelor's degrees and secondary school teachers shculd be holders of Master's degrees.

f. To improve the quality of education the curriculum w11 be revised, textbooks will be developed and the student/teacher racios at the different levels will be reduced.

8.51 In higher education the strategy comprises (a) adjustment between supply and demand, (b) commitment to employment of university graduates, and (c) substantial increase in enrollment in technical fields.

\section{(ii) Aralysis of Present Strategy and Plan}

8.52 Basic education is given high priority in the Seven-Year Plan as an important factor for "the spread of literacy, economic development and modernization of the country's social structure. It is also regarded as the first step towards affording all members of the Afghan society equal opportunities." (Plan p. 210). The Plan envisages an improvement in the delivery of basic education in terms of (a) lowering school starting age gradually from 7 to 6 and instituting kinderga:teas, (b) merging several village schools into an eight-grade primary school or merging several village schools with a sixgrade school which will then be transformed into an eight-grade school, (c) lowering the student/teacher ratio from 43.8 to 26.8 , (d) reducing the male/ female ratio from nearly 6 to 3 and (e) paying due attention to geographic and demographic equilibrium and to wastage in the system. Subsequent to the publication of the Plan further analysis carried out by the Ministry of Education has led to their proposing less ambitious targets for female enrollment (a reduction in the male/female ratio from 6 to 5 instead of 3 ) and the teacher/student ratio (from 43.8 to 35 instead of 26.8 ). The plan targets are shown in detail in Vol. II, Table 12.6 and are summarized for all forms of education in Table 38 below. 
Iable 38: SUMMARY PLAN TARGETS

\begin{tabular}{lrrcc}
\hline & \multicolumn{2}{c}{ Enrollment $(1000)$} & $\begin{array}{c}\text { Year } 82 / 83 \\
\text { as \% of } \\
\text { Year } 75 / 76\end{array}$ & $\begin{array}{c}\text { Year } 75 / 76 \\
\text { as \% of } \\
\text { Year 68/69 }\end{array}$ \\
\hline Primary & 789.1 & 1280.0 & 162.2 & 157.2 \\
Secondary & 89.7 & 148.1 & 165.1 & 372.2 \\
Vocational & 4.0 & 40.4 & 1010.0 & 173.9 \\
University & 8.2 & 11.3 & 138.0 & 76.1 \\
\hline
\end{tabular}

8.53 While the present primary school system is plagued with limited horizontal access to education with one of the lowest enrollment ratios in the world and with very high wastage, the adopted strategy and projected plans do not seem to improve the situation. Instead of widening the base of scholarization by expanding enrollment, the Plan calls for an investment of the country's limited resources in a vertical expansion of the primary school system, $K G$ on one side and Grades 7 and 8 on the other. Although such an expansion would increase the age-specific enrollment ratio to about 40 percent, an alternative of horizontal expansion of a six-year cycle would lead to an age-specific enrollment ratio exceeding 50 percent within the same period of time, and a larger number of primary level schools that can have wider distribution, and consequently, a positive effect on the index of equity. If the funds for the establishment of KG's, (PIan Annex TabIe 92) are diverted to the expansion of primary education, 21,000 additional places could be provided. The vertical extension of the basic education cycle makes the system more expensive, because firstly there is research evidence that the lengthening of the cycle correlates positively with dropout rates, and secondly, plans for universal basic education become financially prohibitive to implement due to the compounded cost per successful completer of eight grades.

8.54 The rationale for the extension of the basic cycle is the assumption that children need at least eight grades of schooling to become permanently literate. This ignores two fundamental points about the determinants of achlevement and the meaning of literacy. First, what a school system provides within a certain set of grades or years is much more important than the number of years. An investment of a small percentage of the cost of adding two more grades to improve the quality of the primary schools or even the village schools would lead to a more definite improvement in educational outcomes. Moreover multigraded schools, run properly, have proved to be as successful as the traditionally structured ones. Secondly, 11teracy retention involves continuous use of the acquired skills. In settings where reading and writing are not used, even seventh and eight grade graduates would probably soon lose such skills. On the other hand, if the communications infrastructure in Afghanistan is developed to demand the use of 1iteracy skills, even children with fourth grade level will be encouraged to use and develop these skills. 
8.55 The vocationalization of Grades 7 and 8 to provide "better employment conditions" for graduates, although significant in itself, may not have the desired impact on production. Less than one-third of primary school-age children are in school and when the net enrollment ratio is adjusted for repetition and over-age, the proportion drops to less than one-fourth. Of those about 40 percent complete the six-year cycle and only half of the completers will be allowed to enter secondary schools. Thus all the investment is geared to the 15 percent of the corresponding age group who reach the seventh and eighth grades and the maximum 7.5 percent who will be allowed to continue their education.

8.56 The original Plan proposal to reduce disparity in enrollment between boys and girls by raising the enrollment ratio from one girl to nearly six boys to one girl to three boys was commendable. However this increase in the female school population would have virtually exhausted the planned increase in the enrollment ratio and would have left the percentage of boys in school nearly constant. Moreover enrollment of girls in school is not a matter of availability of places but is deeply related to relevance of curriculum, social attitudes and parental awareness of the need to educate girls. The more realistic proposal put forward by the Ministry of Education to raise the ratio to one girl to five boys should be attainable if the necessary training of women teachers is carried out and the necessary political support at both the national and local level if forthcoming.

8.57 While the Plan assumes that a reduction in the student/teacher ratio "will be indicative of improvement in the educational qualicy," this assumption is not supported by research findings. On the contrary some studies have shown that certain skilis, especially reading, are better achieved in large classes. Small classes in themselves do not guarantee an improvement in the teaching-learning process such as individualization of instruction and activity-oriented learning. What is more important than class size is what the teacher does with the opportunities the size of the class offers. The scope of effective ways of teaching in relatively large classes has not been exhausted. It would be pointless to decrease class size so that teachers can lecture and dictate to smaller groups of students, when the increase in cost is tremendous. The original proposal to reduce the student/teacher ratio from 43.8 to 26.8 required an additional 18,475 teachers over the 29,225 teachers needed otherwise (Vol. II, Table 12.6). Aside from the question of the feasibility of providing these large numbers of teachers (see para. 8.61 below) the recurrent budget would have had to be increased by more than 50 percent since salaries of teachers constitute the major part of it. The new proposal to reduce the ratio to 35 , while more practical, would still not adequately address the problems raised above.

8.58 "To spread Iiteracy and extend equal opportunities", a rethinking of the strategy for basic education is needed, in terms of substance rather than form, which will be accessible and relevant to a wider group of the population, through the adoption of a community-based curriculum. Such a curriculum should oe derived from the personal and economically productive needs of the community and sensitive to the differences in such needs among sexes and regions. The quality of education should be judged in terms of the 
relevance of what children learn to their lives after leaving school rather than how many pupils reached the eighth grade. It is also recommended that such a curriculum be coupled with the development of an evaluation scheme that is diagnostic in nature and which could lead to the possibility of reintroducing some sort of an automatic promotion system at the early grades to reduce wastage due to dropout and repetition.

8.59 At the secondary level the Plan tries to make up for the previous imbalance between academic and vocational education, by 1mposing a moratorium on the number of general secondary schools and proposing a large increase in vocational schools. By the end of the Plan the ratio between enrollments of academic and vocational high schools will be $3.6: 1$ compared to a ratio of 25.3:1 in the first year of the Plan. According to the targets in Vol. II, Tables 12.6 - 12.10, there will be, during the period of the Plan, 314,500 eighth grade graduates of whom 67 percent will enter general secondary schools, 16 percent will enter vocational schools, and the remaining 17 percent, i.e., more than those to be prepared vocationally, will enter the labor market. The Plan proposes six-month to two-year training courses for this last group of school leavers within the framework of vocational education and partly under the training programs of industrial organizations. It is worth noting, however, that such a proposal nearly doubles the load on vocational schools in terms of space, teachers and budget, and the Plan makes no provision for such a load.

8.60 The small quantitative increase at the general secondary level is accompanied by attempts to improve the qualicy of education by providing textbooks and science laboratories and reducing the average number of students per teacher from 35 to 30 "as a consequence of which, the quality of teaching will go up" (Plan p. 213). Once more the reduction of the student/teacher ratio is not strongly supported on educational grounds, while economically it costs the system an extra 1700 teachers during the Plan period with obvious implications for training and recurrent expenditure. It is also important to note that the qualitative improvements are along conventional lines and based on the assumption that this kind of education is university-oriented. The facts are different. During the seven-year period of the Plan 139,000 students will graduate from the general secondary schools and 18,900 from the vocational schools (Vol. II, Tables 12.7 and 12.8). During the same period entrants to Kabul University are 19,900 and the Teacher Training Colleges 43,200. Even if it is assumed that no vocational school graduate enters the University or College, and at the same time the over-ambitious targets for the Teacher Training Colleges at a post-secondary level are accepted $\underline{1} /$, then half of the general secondary graduates (three times the number of graduates of vocational

1/ Enrollment target figures for the DMA's are assumed to be at the postsecondary level although there is ambiguity in the Plan regarding the time schedule for the implementation of the upgrading of the teacher tralning program (para. 8.50e) and the grade level of the entrants to the DMA's during the period of the PIan. 
schools) will still enter the labor market with university-oriented preparation and no training. Thus there is a need to rethink the role of general secondary schools and restructure and diversify the curriculum to cope with the needs of the growing numbers of graduates who will not go into higher education.

8.61 During the Seven-Year Plan, vocational education is to be expanded nine-fold by opening new schools and increasing the capacity of existing ones. In the distribution of facilities by subject of specialization (Vol. II, Table 12.8) agricultural education is not treated in proportion to its importance in the economy, and the bulk of the expansion ( 48 schools with additional enrollment of 26,200 students) is in areas that "will be determined after appropriate studies." The number of teachers needed will increase from 114 to 1,224 with the annual increase reaching 324 in $1982 / 83$. Considering the number of graduates from Kabul University during the years of the Plan (Vol. II, Table 12.13), it will be virtually impossible to provide for such an increase in the teaching staff. Moreover, the enrollment targets are not realistic because there is insufficient allowance for the time needed to build and equip the schools proposed in the Plan.

8.62 The strategy for vocational education in the Plan is based on (a) the development of a small number of specialized persons who will generate development at the top, largely within heavy capital intensive industries which the government will initiate, and (b) the feasibility of establishing a formula of correspondence between curriculum specializations and various manpower demands of the modern sector of economy. The market for skilled manpower in a number of subsectors is very small whicl. raises questions regarding the mode and scope of middla- and high-level manpower training. Moreover the major share of development expenditure is in areas which are relatively capital-intensive and wich will use a small number of workers. If the Government persists in this employment policy, and at the same time pursues a development policy which is not geared to the gezeration of mass employment, then vocational education needs to be flexible both in terms of its structure and mode of delivery.

\subsection{The Seven-Year Plan recognizes the importance of high quality}

teacher training in the implementation of gducational reform, but the coni $3 p$ t of quality, as in the case of the strategy for basic education, is expressed in the form of lengthening the training period. This strategy may be just $1-$ fied in the promotion of an elitist system of education, but when the announced objective of the reform is an expansion of the base of practical education for the mass of the population, such a strategy is expensive and inefficient in the use of the facilities and training staff of the teacher training colleges. Moreover, quality does not increase pari passu with an increase in years of training. Four-year (or even two-year) post-secondary graduates are likely to be over-trained and mis-trained for the kind of practical, community-oriented curriculum appropriate for the basic education cycle, particularly in rural Afghanistan. On the secondary level, the major worry is also the inappropriateness of the training curriculum and the lack of emphasis on occupational, vocational and practical arts on one side, and modern methodologies on the other. 
8.64 The target figures for teacher supply (Vol. II, Table 12.9) assume that the unqualified teachers presently employed will not be replaced. Even then, these targets cannot be met if the duration of training is expanded as proposed, as a number of new teacher training colleges will have to be built and equipped during the period of the Plan. Most likely they will not begin to produce graduates before the fourth year of the Plan or even later because of the time needed to construct them and provide them with teachers through the expanded program of the Academy for Teacher Educators.

8.65 Development of higher education is singled out in the PIan as "the pivot for the educational endeavours of the Republican Regime." However the objectives of such development are expressed in vague qualitative terms such as "compatibilicy with scientific realities and national requirement." These need to be spelled out operationally. The projected quantitative expansion (Volume II, Table 12.11 and summary Table 38) is so modest that the present actual intake and enrollment figures at Kabul University (Vol. II, Table 12.4) exceed the target figures for the last year of the Plan. There is a danger that such a rapid growth which is not synchronized with expansion of physical facilities and teaching force, will hurt the quality of instruction. The policy ior higher education also lacks a definition of the role of the University in the overall development of the country, and the relationship between the University and the development and research agencies like those of the Ministries of Agriculture, Health, and Mines and Industries.

8.66 The narrowness of the formal system of education gives non-formal education a significant role in the social and economic development of Afghanistan. About one-third of the population is under the age of 10 and about 55 percent under the age of 20. This majority of the population who will be the productive core of the country in the next few decades will not have enough opportunity in the formal system, as a high proportion will either not enter school or will drop out after a few grades. Even with the targeted growth of primary education there will be, according to the Plan, more than $1,800,000$ children age 7-14 out of school in the year $1982 / 83$. When the figures are corrected for over-age and repetition the number exceeds two million.

8.67 The Plan for non-formal education is very modest compared to the need. The target of educating 384,000 adults during the seven-year period of the Plan, is 1nsignificant when we note that the "pool of illiterates" is annually increased by the number of children of age? who do not enter school (in addition to drop-outs in the early grades). During the same period the total number of such children is 1,200,000 (Vol. II, Table 12.6) more than three times the number of persons made literate. In addition the planned program has little impact on the female population which is already underrepresented in the formal system.

8.68 To cope with the great demand for non-formal education, it is firstly important that, as nonformal education is expanding, the base of formal education grows much faster than population growth, so as to reduce the input into the illiteracy pool. This will require clear targets for universal primary education within a reasonable time schedule. Secondly, non-formal education should be a concern of all Ministries and development 
agencies, and linked functionally with the Rural Development Program and the regional development projects of the Plan. Thirdly, the legislation and regulations regarding implementation of the programs must be flexible and nontraditional to allow the hiring of skilled instructors who do not necessarily have formal academic qualificalions. The long-term solution to this problem is in the revision of the primary teacher training program to prepare primary ceachers, not as academicians, but rather as community development promoters who will have the skills to teach in-school children and out-ofschool youth and adults community-oriented skills. The vastness of the clientele for non-formal education justifies a comprehensive plan at least as detailed and ambitious as the one for formal education and a series of studies dealing with the use of different modes of delivery including the mass media.

\section{E. Education and Development}

8.69 In order for education to fulfill its role in the social and economic development of Afghanistan, certain modifications in the strategy for educational development are needed. There has been clear evidence since the formulation of the Plan, that the necessary re-thinking of priorities within the education sector is taking place, and a broad agreement is emerging on objectives which has already resulted in some useful actions being taken. The task ahead is to build on these initial steps. The thrust of the foregoing analysis, is to develop an educational system that is more community- and development-oriented than institution-oriented. The first aspect is to restrain vertical expansion and promote a faster growth of basic education by improving the distribution of education opportunities and increasing enrol1ment capacity. The implementation of horizontal expansion can be expedited on an equitable basis among regions by (a) carrying out a master activity of school mapping to establish a "carte scolaire" for optimal localization of primary schools on the basis of geographic distribution and population density; (b) improving the quality of the existing village schools in terms of facilities, curriculum, and teachers, and establishing similat new multigraded primary schools in areas where population does not justify a regular graded school; and (c) considering the possibility of a nuclear system of schooling based on a $(4+4)-4$ structure whereby a number of four-grade schools feed into a smaller number of complementary schools that have Grades 5 ar. 5 or Grades 5-8, which in turn feed into a smaller number of secondary schools, On the non-formal level the scattered education and training activities need to be expanded within an overall plan to cope with the growing size of the out-of-school population and provide lateral coordination among the different agencies involved to produce a cumulative impact.

8.70 Since a major constraint to expansion of educational opportunities is the low efficiency in the present performance of the system (paras. 8,41 and 8,42 ), some measures need to be explored to improve this efficiency. While an overall improvement in the quality of the system positively affects efficiency and a shortening of the basic cycle decreases dropout rates, more direct measures are also proposed. Among these are (a) a modification in the policy of student flow to reintroduce some kind of automatic promotion in the early grades, (b) a revision of the examination system to make it more diagnostic in 
nature, (c) an acceptance of the present student/teacher ratios, and (d) a higher utilization of the physical facilities by rotational scheduling and double shift.

8.71 Relacing education to economic productivity is constrained by the inadequacy and unreliability of quantitative data on manpower and employment. What is needed is an employment policy study that analyzes (a) the development policies and their implications on employment and (b) the manpower implications of the various employment policy alternatives. Such a study will assist in the formulation of an appropriate education and manpower development policy and implementation schemes. From what is available, however, it is clear that while the major share of training is geared towards the modern sectors, the traditional sectors of agriculture, livestock and handicrafts produce over 60 percent of the national product and employ nearly 70 percent of the labor force. Iraining, both within the context of basic education and as a separate activity, should therefore include economic and technological skills that are helpful in improving the productivity of those employed in these traditional sectors. This does not mean that skill requirements in rural areas are only agricultural - there is also a role for related skills such as mechanical repalrs, woodwork, masonry, weiding, and simple bookkeeping. In orher words, a balanced training policy is needed to enhance traditional village and middle-level technologies while contributing to the development of the modern sector. Formal vocational institutions cannot cope with the vast need for such skill training and must therefore be supplemented by other modes of training such as mobile training units, extension programs, and projectrelated training. In addition, the concept of non-formal education must expand beyond functional literacy which attracts only a limited sector of the out-of-school population (para. 8.68). Rural development centers, where available, can be used as a base for coordination and operation.

8.72 On the more specialized level there may be difficulty in meeting specific manpower needs. The implementation of the development projects of the Plan requires about 14,500 high level personnel (Table 39) while the University would graduate no more than 12,500 within the same period according to the Plan proposal (para, 8.65). 
Iable 39: MANPOWER REQUIREMENTS OF THE PLAN

\section{Field}

Chemistry

Geology and Mineralogy

Mechanics

Power and Water

Technicians

Mines

Agriculture

Construction

Cartography

Economics and Administration

Medical Staff

Teachers

Other Occupations

High Level

101

349

716

613

89

176

1,259

613

56

3,156

1,830

5,407

117

14,482

Medium Level

TOTAL

\section{Source: Plan P. 56.}

The shortage would be mainly in the productive fields of both industry and agriculture. In the industrial sector the high demand for engineers has already prompted the University to increase the intake into the Faculty of Engineering to cope with this need (para. 8.35) but without taking the necessary steps to preserve the quality of training by providing adjitional staff and facilities. Such a measure, while solving the quantitative manpower problem, creates a more serious problem for the productive sectcr by providing low-quality training. In agriculture, the supply of professional veterinarians and animal husbandry specialists will be very inadequate. At the subprofessional level, although the Plan asserts that the demand for the 8,703 mediumlevel personnel in the productive sectors will be met by the output from the vocational schools, it is most unlikely that such demand will be met by the conventional institutions of training (para, 8.61). The situation requires a diversified approacin to craining which includes (a) vocational schools to prepare manpower with a wide range of skills derived from related industries, (b) smaller vocational schools attached directly to enterprises, which can respond in a flexible way to their needs, and (c) project-related training ranging from special courses to on-the-job training. The curriculum for all these programs must be skill-oriented in formulation and implementation and based on a careful task analysis of the competencies needed for the different job specializations.

8.73 Qualitatively, the basic education curriculum needs to be community oriented for social and economic development in rural Afghanistan. While the young people in rural areas are most open to change, the primary schonl has, unfortunately, had little effect on rural development, because of the limited relevance of its program. The core of the curriculum should, therefore, be the 
range of skills needed by the rural population, namely, (a) income-producing skills in agriculture and/or livestock; (b) auxiliary skills of home management, health and conservation of environment; and (c) skills for self-reliance and self-management that cover literacy, numeracy, cooperative management, and community organization. While a curriculum oriented towards preparation for further education discriminates against those that do not go into further education and alienates them, a community-oriented curriculum does not hurt those that proceed beyond basic education.

8.74 The strategies described above necessitate a revision of teacher training programs. The preparation of primary school teachers for rural education and community development implies significant changes in the curriculum, facilities and teaching methods in the DMA's. The program for training secondary teachers needs to be practically and pedagogically oriented. Programs for the preparation of teachers of vocational and technical courses need to be institutionally developed at Kabul University, and the legislation modified to allow the employment of specialized skill instructors who may not have the necessary academic qualifications. On the administrative level the coordinating body between the Ministry of Education and the Ministry of Higher Education needs to be formalized and to meet more frequently in order to coordinate the teacher training policy and supervise its implementation in the institutions belonging to the two Ministries. The Academy (para. 8.29) needs to be developed into an effective agency for educational innovation either as a part of Kabul University or as an institute for educational research and development.

8.75 The implementation of the educational strategies for development of Afghanistan requires an efficient and effective educational management in three areas. Firstly, on the central level, the problem of synchronization and coordination among the various units of the Ministry of Education dealing with the different processes of curriculum development can be resolved by a consolidation scheme. One approach is to consolidate all the development functions in the form of a research and development agency with some. autonomy and administrative flexibility to attract outstanding education specialists. Parallel to this an administrative structure for implementation, management and supervision should be organized on the basis of functional analysis. The planting unit, in this case, becomes d btaff office attached to the Minister's office and serves as a secretariat to a planning board that reflects community participation. Secondly, it is very important under any scheme of reorganization to strengthen the provincial offices of education by raising the qualifications and rank of the education officer and equipping the offices with a cadre of professional staff that is capable of carrying out supervision and development functions effectively. Thirdly, the functional relationship between the Ministries of Education and Higher Education needs to be spelled out operationally. Since there are various approaches to this question of organization and management a study is suggested to examine the different alternatives and draw up an educational management plan.

8.76 The importance of the role of human capital in the economic development of Afghanistan is not reflected in the proportion of the Plan budget allocated to education. While in the previous Plans about 4 percent of the 
development budget was earmarked for education, in the present Plan only 1.7 percent is devoted to the development of education. In respect to the ordinary budget, an average of 16.5 percent during the period of the Plan is maintained for education which does not indicate any recognition of its priority status. The functions that the education and training systems are expected to perform within the national development plan, aside from the problems created by past restrictive policy, require a significant upward revision of both budgets. 


\section{THE PUBLIC HEALTH SITUATION}

9.01 Health care is one of the greatest concerns of the people of Afghanistan. In areas where new roads are ending isolation, often the greatest benefit that is perceived is not access to markets and means of increasing income, but the possibility of using health services. The scope of the national health problem is staggering - currently at most one-fourth of the population is within reasonable reach of modern health care - yet health services are one of the lowest priorities of the Plan. And the health program as it stands does not relate adequately to elther the health environment of the country or the Ministry of Public Health's declared priortties.

9.02 By international standards the public health effort of Afghanistan is weak. In $1976 / 77$ total health-related public expenditure was about Af 57 $(\$ 1.20)$ per capica, and comprised about 0.65 percent of estimated GNP. $1 /$ Approximately 2.5 percent of the total budget allocation (development and ordinary) was allocated to health. By all three criteria, Afghanistan currently ranks among the bottom fourth of developing countries. Nor are the prospects for improvement good; over the Plan period, only 1.9 percent of projected expenditures are for health. 2 l

9.03 Modern health services are new to Afghanistan. They are being introduced into a society in which traditional approaches to health care, which have evolved over centuries, are still deeply ingrained in the culture. The ultimate effectiveness of the modern public health system is largely dependent upon the extent to which it can become part of the peoples overall approach to health care and the effectiveness of the health program itself. These two faciors will determine the degree to which people will forsake their traditional misconceptions and avail themselves of modern health services. This in turn will help determine the pace at which the public health program can make inroads into the ezormous health problems of the country.

\section{A. Health Perceptions}

9.04 In a councry that has been as isolated for as Iong as Afghanistan, it is not surprising that health is surrounded by scores of traditional

1/ Includes ordinary (recurrent) and development budgets, and foreign assistance, About Af 36 per capita ordinary budget; Af 21 development budget. Urban water supply projects not included. Even if they were included, per capita expenditure would still only be Af 70 , health expenditures 0.8 percent of estimated GNP and 3.2 percent of total budget allocations in 1975/76. Source: GNP - see Volune II Table 2.1, First Seven-Year Plan, Ministry of Public Health, and 1356 Ordinary and Development Budgets of Afghanistan.

2) 1.2 percent of development budgets, 3.2 percent of ordinary budgets. Source: First Seven-Year Plan. 
beliefs. The health care system begins at home. When someone falls ill, the first cures followed are usually traditional ones -- bed rest, herbal medicines prepared by the women and diet change. The traditional Greek s"stem of "hot" and "cold" foods is adhered to. Depending upon the illness and body temperatures, foods of one type or the other are prescribed. In some cases, diet change constitutes withholding foods altogether as is often done in the case of diarrhea/dysentery. And then there are special treatments; for example, cures for hepatitis call for stringing onions around one's neck or swallowing a written verse from the Koran. Metaphysical beliefs play an important role in explaining and curing illness. In the case of repeated infant mortality, or otherwise inexplicable death, jinns and evil spirits are believer to be the cause. Almost every child gets an amulet at birth prepared by the mullah to ward off evil spirits. Other protection is seen in drinking water in which a witcen verse of the Koran has been immersed. Similarly, prayers and vows are among the first actions taken at onset of iliness e.g., "If my son's health improves, I promise to visit the shrine every Friday for a year."

9.05 If household cures prove unsuccessful, the next level to which the family turns is usually the village. Persons contacted at this level include dais (midwives), bloodletters (usually the village barber), and the mullah. The mullah performs multiple functions, from allaying peoples fears of evi: spirits, to praying for the 111, and if he is a progressive man, to referring the patient to proper health authorities. Also located in some villages are small stores that stock a few basic medicines.

9.06 In the nearest bazaar, the next level of treatment is found. It usually comprises tradicional medical practitioners, herbalists, bonesetters, holy people claiming descent from the prophet, and in some cases, shrines known for their ability to cure particular illnesses. Also located in some bazaars are pharmacies and Basic Health Centers (BHCs). In theory, BHCs have a medical staff of 7 , and carry basic medicines that, if available, are dispensed free. They are also intended to provide immunization services, maternal and child health services, and sanitation education. The BHC is the outpost of the modern health delivery system. From there the path leads to the provincial centers, with doctors, hospitals and pharmacies, further to regional centers, and finally to Kabul, with increasing degrees of specialization and sophistication. Operating vertically throughout the entire system are the mass eradication programs for smallpox and malaria.

9.07 The modern health system is thus merely one element in a vast array of health services, and in most areas is only the last resort. But in regions where modern medicine has made inroads, such a dichotomy does not appear to extst, all cures are part of the one health care system. If traditional cures fail, the modern are sought, and vice versa. Nor have city dwellers discarded the traditional sources; even in Kabul doctors prescribe traditional herbal medicines to supplement drugs. Rather the whole approach to health care appears eminently rational, the effective cures are retained and the others discarded, be they of modern or traditional origin. 
9.08 Where modern health services are available, peoples' perceptions of illness and cure have naturally changed. Jinns and evil spirlts are belng replaced by "microbes" as causes of 11 lness; if anything, the pendulum has swung too far. Ir some cases traditional cures that sometimes helped and were rarely harmful have been discarded and patients will do anything to get modern medicines often regardless of how inappropriate they may be. Nor are they usually content wh a single medicine; often prescriptions are written for several medicines that perform basically the same function, and there is almost religious faith in injections.

9.09 In a study of three provinces in 1976/77, an average annual expenditure on health of Af 2,878 per household (Af 402 per capita) was reported, with a median expenditure of Af 1,000. 1/ In another study, of 254 farmers in Parwan province, average expenditure on health was reported to be Af 918 per household (Af 151 per capita). 2/ This is three times the average public health expenditure per capita of Af 50. The significantly higher expenditure per capita in the first study can at least partly be explained by Baghlan and Helmand being perhaps the two most prosperous provinces in the country. In the Parwan survey about 4.6 percent of household income was allocated to health (compared to 8.6 percent in the U.S.). Respondents in Parwan allocated theit health expenditures as follows:

\section{Table 40: ALLOCATION OF HEALTH EXPENDITURES IN PARWAN PROVINCE - 1975}

\begin{tabular}{lr}
\multicolumn{1}{c}{ Treatment } & Percent \\
\cline { 2 - 2 } Pharmacy & 32.3 \\
Shrine & 11.9 \\
Kabul - Doctor and Hospital & 19.7 \\
Provincial - Doctor and Hospital & 10.3 \\
Mullah & 8.6 \\
Besic Health Center & 2.1 \\
Traditional Practitinners & 5.3 \\
Village store & 5.2 \\
Other & 4.6 \\
Total & \\
\end{tabular}

Although the accuracy of these surveys must be open to considerable doubt, they nevertheless give a broad indication as to how villagers allocate their health expenditures; about 40 percent of expenditures are on medicines, 30 percent for doctors' fees and hospital-related expenses, and about 30 percent on traditional cures.

1/ Management Services for Health (MSH), The Village Health Worker: The Need and Potential as Determined by Survey in Three Provinces of Afghanistan, Kabul, 1977.

2/ Management Services for Health (MSH), Preliminary Report: A Village-Leve I Health Survey in Afghanistan, Kabul, 1975. 
9.10 Attitudes to modern medicine are characterized by open-mindedness and a desire for better cures. Unfortunately the notion of preventing illness before it occurs is still a forelon one. The majority of the population are oblivious to the true causes of disease - polluted water, improper sanitation practices, and malnutrition, are as little recognized as the causes of illness as they ever were. In short, there is no concept of preventive medicine. However, one cannot only fault the villagers, the same short-sightedness pervades the entire medical community, and but for a few small though notable programs, guides the nation's health strategy.

9.11 Polluted water is perhaps the single most important cause of disease in Afghanistan 1/. Afghans like good, clean water, but the overriding consideration when alternative sources are avallable is convenience. Unfortunately the most polluted water source, the fui or canal, is usually the most convenient. The 3-province survey mentioned above found the following pattern of water sources: 22.9 percent of households used a we 11 in the yard, 1.6 percent a we 11 in the village, 5.9 percent a river, 37.8 percent a jui, 12.8 percent a spring and 19.1 percent a karez. When asked if they were satisfied with their water supply, 78 percent said they were. This is one reason why up to 50 percent of the drinking water wells installed by the Ministry of Public Health have fallen into disrepair and people have simply reverted to their original source. There is evidence in individual cases that villagers realize the benefits of safe water and that they can be persuaded to maintain drinking water systems by communal efforts. This base must be built on through increased public awareness of the importance of unpolluted water. Until this is done, not only are the drinking water programs ineffective, but the public health program is dissipating scarce money, medicine, and manpower on treating preventable diseases.

9.12 Adults in general are aware of the 1mportance of environmental sanitation and tend to keep away from Juls and wells; however, children and animals display no such restraint. In addition, the jui serves as both washstand and laundry. Private latrines are often situated near other persons weils and vice versa. In the above survey, 3.7 percent of the houses had their latrines in their own house, 39.2 percent within the yard, 3.7 percent used a deep hole in the yard, 15.3 percent a deep hole outside the yard, and 27.5 percent had no facilities at a11. Not that such families or villages are necessarily worse off; on the contrary, some villages where private latrines were installed in the past show higher parasite incidence than similar villages without such latrines. The chief blessing of a latrine is often not perceived in terms of health, but rather as a convenient collection point for night soil which $1 \mathrm{~s}$ subsequently spread on the fields. The parasite cycle is then completed as man consumes the food. Once again, latrine programs, 1ike drinking water programs, are only part of the solution; the public must be made fully aware of the underlying reasons why continuous preventive health measures are needed.

1/ See paras, 3.21 to 3.24 . 
9.13 The public is also unaware of the importance of nutrition, and fails to identify it as a principal determinant of susceptibility to illness. 1/ Again mass educarion is required, particularly of women, in making them aware of children's special needs. Other aspects of malnutrition are more intractable and will only come with increased incomes of the needy, and an improved transportation system.

\section{B. The Public Health Program}

9.14 The National Health Plan for $1976 / 77$ to $1982 / 83$, drawn up by the Ministry of Public Health (MOPE), calls for development expenditure of Af 2 billion in the framework of the Seven-Year Plan. Simultaneously, current expenditure is to increase from Af 330 milion in $1976 / 77$ to Af 511 million by $1982 / 83$. All aspects of public health services are to be expanded as shown in Table 41 below.

\section{Table 41: KEY HEALTH PROGRAM INDICATORS 1976/77 - 1982/83}

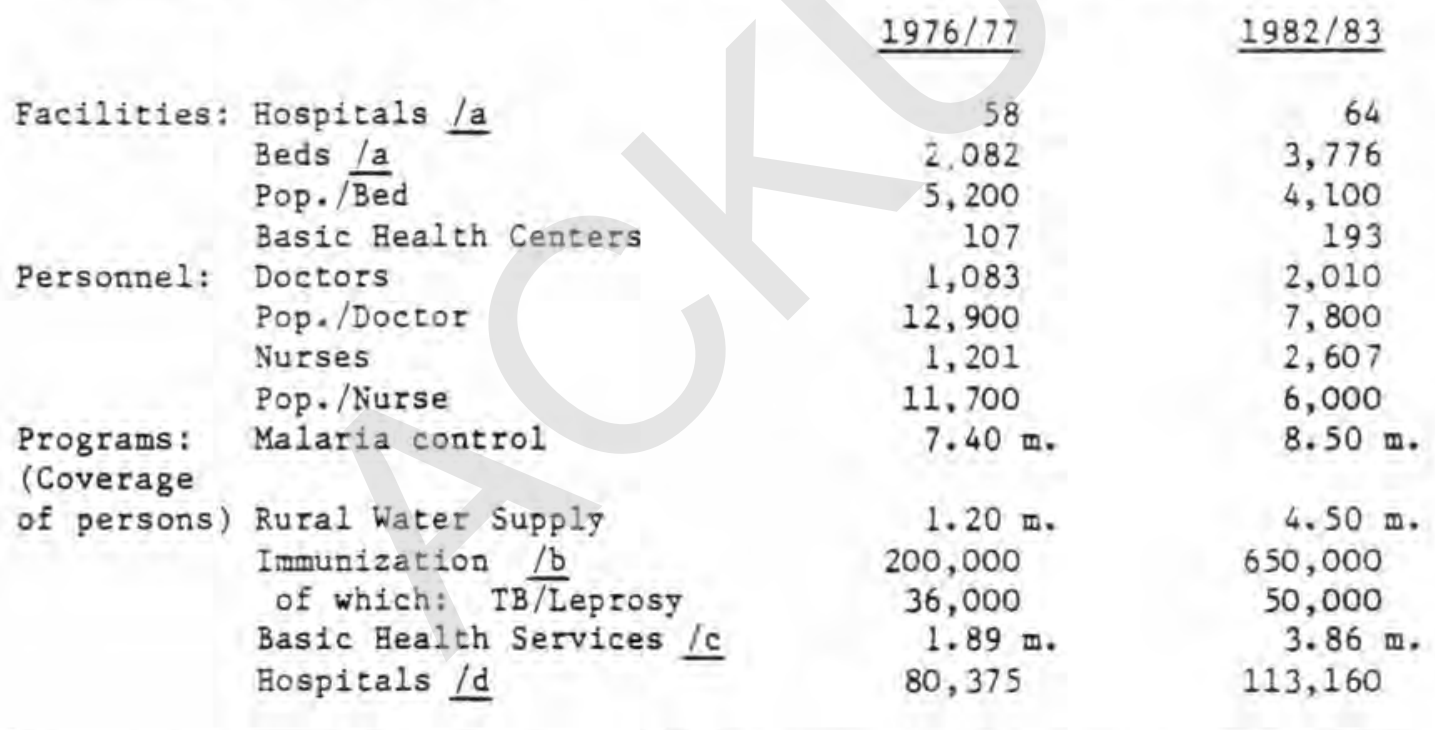

la Excludes military hospitals.

$\frac{1 b}{1 b}$ Diptheria, Polio, and Tetanus (DPT); BCG, smallpox.

Ic See Table 50 for assumptions.

Id Average length of stay and bed occupancy rate assumed constant over period.

Souz:es: 1) The First Seven-Year Plan, Ministry of Planning, Kabul, 1976.

2) Management Services for Eealth (MSH), Einancial Analysis of Health Programs, Kabul, 1977.

3) Ministry of Public Health.

1/ See paras. 3.15 to 3.20 for a detailed review of nutritional problems. 
9.15 While this is not in itself an overly ambitious program, MOPH is nevertheless finding itself hard-put to fulfill it. By its second year the National health Plan had already undergone substantial revision, and $1977 / 78$ ordinary budget allocations were cut by 13 percent because the Ministry of Finance felt MOPH was unable to absorb its requested budget. I/ More disturbing than the size of the cut though is the way in which the cuts were distributed. As the following table indicates, some critical trade-offs have been made.

Table 42: 1977/78 PLANNED HEALTH EXPENDITURE BY MAJOR PROGRAM (Af Million)

$\frac{\text { Original }}{\text { Own Project }}$
Resources Assistance

1) Immunization

2) IB/Leprosy

3) Malaria

4) Rural Water Supply /a

5) Basic Health Services

6) Hospitals

7) Administration, Iraining, etc.

$\begin{array}{rr}7.4 & 2.3 \\ 6.0 & 30.7 \\ 69.5 & 49.9 \\ 13.1 & 37.0 \\ 76.0 & 40.7 \\ 173.6 & 49.7\end{array}$

89.6

445.2

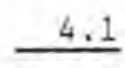

214.4

$\frac{\text { Revised }}{\text { Own Project }}$
Resources Assistance

3.0

2.3

3.9

30.7

49.9

8.8

40.7

58.0

49.7

191.5

4.1

55.0

388.5

186.2

la Af 3.6 million - ordinary budget; remainder development budget.

Source: MOPH.

Note - In the revised plan, Af 315 milion (excluding project assistance) comes through the MOPH ordinary budget, covering programs (1), (2), (5), (6), and (7).

I) The Ministry of Public Health's ordinary budget contains only about half of total recurrent expenditures in the health field, and is consequently misleading. For instance, the malaria program, which comprises about one fourth of total recurrent expenditure, is a vertically-organized program operating independently and parallel to regular MOPH activities. It draws its funds directly from the Ministry of Finance. Furthermore, MOPH and the malaria program both receive large amounts of foreign assistance for recurrent costs that never appear to enter the budget. Such practices inevitably distort the true health resource allocation picture, and hinder comprehensive programming and budgeting. The ordinary budget should, like the development budget, explicitly include foreign assistance. This would enable the budget of the MOPH to be seen as a whole instead of the confusing sum of independent parts it is now. 
9.16 In essence, urban health services have been increased, and rural services reduced, for although overall expenditure on health programs have been cut by 13 percent, planned hospital expenditures have been increased by 8 percent, while expenditure on malaria control, immunization, rural water supplies and Basic Health Services, all programs that are essentially rural in impact, have suffered a combined reduction of 19 percent. Only in the case of the rural water supply programs was an expected shortfall in project assistance the cause. Thus reallocation of funds only serves to reinforce the disproportionate emphasis on urban-oriented health services that the plan already embodies - over 49 percent of planned 1977/78 expenditures are now for urban hospitals and outpatient services.

9.17 The rural programs may well have been overly ambitious, and are by nature the more difficult to deliver, yet they are the more urgent prioritles. The original budget request for an increase of about 25 percent over $1976 / 77$ was not unreasonable. The programs that were cut were the very programs slated to increase the most over the Plan period as percentages of total health expenditures - immunization from 1.5 percent to 3.2 percent and rural water supply from 7.6 percent to 25.0 percent. (Malaria eradication on the other hand, is to drop from 18.2 percent to 15.1 percent and hospitals from 48.5 percent to 38.9 percent,) It is highly questionable whether the targets of the $1 \times 30^{\circ}$ s can be met if the current trend persists - programs designed to achieve them are cut and those programs envisioned to be reduced are expandes. For instance, the rural water supply program was originally intended to reach 300,000 people in $1977 / 78$. That has since been reduced to 225,000 and, with the shortfall in project assistance, it is doubtful it if wlll even reach 100,000 which is less than half the natural increase in the rural population. As difficult as rural programs are to 1 mplement, rural Afghanistan constitutes by far the largest part of the national health problem, and it is on MOPH's success in improving rural health that the effectiveness of the public health program will ultimately be judged.

9.18 Not only does the $1977 / 78$ budget reveal a disturbing imbalance between rural- and urban-orfented expenditure, the expenditures themselves bear little relation to MOPH's declared priority among different groups within the urban and rural population. In the National Health Plan, priority in health programming was to be assessed on the basis of mortality and the incidence of illness. Consequently, infants were declared the highest priority group followed by children, mothers and the work force. Yet in practice, budget allocations by program result in a pattern of use of services which is out of line with the stated order of importance. This is shown in Table 43 below. 
Table 43: EXPECTED UTILIZATION OF HEALTH SERVICES - 1977/78 BUDGET (Af Milion)

\begin{tabular}{|c|c|c|c|c|c|c|}
\hline & $\begin{array}{c}\text { Infants } \\
0-1 \\
\end{array}$ & $\begin{array}{c}\text { Children } \\
1-14 \\
\end{array}$ & Mothers & $\begin{array}{l}\text { Labor } \\
\text { Force }\end{array}$ & Budget & $\%$ \\
\hline Immunization & 2.1 & 2.1 & 1.1 & - & 5.3 & 1.0 \\
\hline TB/Leprosy & - & 9.0 & 3.5 & 22.1 & 34.6 & 6.7 \\
\hline Malaria & 4.6 & 53.6 & 8.0 & 47.7 & 113.9 & 22.1 \\
\hline Water Supply & 0.9 & 10.3 & 1.5 & 9.2 & 21.9 & 4.2 \\
\hline Basic Bealth & & & & & & \\
\hline Services. & 6.9 & 36.6 & 5.9 & 49.3 & 98.7 & 19.1 \\
\hline Hospitals & 16.9 & 50.7 & $\underline{24.1}$ & $\underline{149.5}$ & 241.2 & 46.9 \\
\hline TOTAL & 31.4 & 162.3 & 44.1 & 277.8 & 515.6 & 100.0 \\
\hline $\begin{array}{l}\text { as percent of } \\
\text { total budget }\end{array}$ & $6.1 \%$ & $31.5 \%$ & $8.5 \%$ & $53.9 \%$ & $100 \%$ & \\
\hline
\end{tabular}

Source: MSa, Financial Analysis of Health Programs, Kabul, 1977, Table 1.

Only 6 percent of total health expenditure is directed at infants who suffer almose 40 percent of total mortality. Similarly, mothers who suffer high maternal tortality and the physical exhaustion of consecutive births receive on 1 y 8.5 percent of the expendicure. On the other hand, those exposed to the fewest health hazards - adult males - are the focus of nearly 54 percent of the health effort. As essential as a healthy labor force is to economic development, it is hardly of the same overriding significance to the quality of life in Afghanistan as the high mortality of infants, children and mothers. This is not to argue that the level of expenditure on hospitals is inappropriate. Obviously one of the important objectives must be to get women to make more use of hospital facilities for themselves and their children. This relates in large part to the low educational levels of the female population and the lack of trafoed female modical personnel.

9.19 The heavy emphasis on urban health services for the work force 15 symptomatic of the fundamental bias of the health system towards curative health services. The breakdown of planned expenditure in Table 42 indicates Af 141 million of Af 514.6 million (excludes MOPH overhead) or about 27.4 percent of planned health expenditures can be classified as preventive; the remaining Af 373.6 million ( 72.6 percent) is for curative purposes. 1/ This heavy emphasis on curative health is typical of most developing countries where modern health services get equated with big modern hospitals equipped

I/ MOPH classifies Basic Health Services as preventive health services; in actual fact very little currently associated with them is preventive. However, as explained in para. 9.15 footnote $1 /$ the budget data has numerous deficiencies which would affect the classification of other items as between curative and preventive. 
with sophisticated equipment and manned by highly trained medical personnel. The connection between preventive and curative medicine is only dimly perceived. It seems to go unoticed that a BCG vaccination costing as little as Af 20 can prevent patients from ultimately having to seek multiple TB treatments at a sanatorium at an average cost of Af 1,050 per treatment $1 /$, or that clean water delivered for as $11 t t l e$ as Af 31 per person can keep someone out of a hospital visit that costs an average of Af 1,930 for children or Af 4,000 for adults. The financial case for increased preventive measures is overwhelming without even considering the suffering and hardship which treatment exact from patient and famlly alike, or the fact that upon release from hospital the patient returns to the very environment from which he or she more than likely bècare 111 in the first place. Clearly, given the overall low level of health expenditures, we would argue that the increase in preventive health measures should be additional to, and not at the expense of the current effort on the curative side. It is important however, that when cuts must be made for one reason or another, the axe should not fall on key preventive health programs, as has been the case in the past.

\section{The Health Delivery System}

9.20 A health program can only be as effectlve as the system that delivers it. The principal components of the current system in Afghanistan are: hospitals, basic health centers, mother and child health care programs, the mass immunization program and the malaria control program. A Village Health Worker Scheme is in the pilot program stage. Of importance to all programs is the avallability of cirugs and manpower.

\section{(1) Hospitals}

9.21 Hospitals provide both in-patient and outpatient services. Inpatient services account zor about 95 percent of total MOPH hospital expenditure, and in $1975 / 76$ about 70,000 patients were treated in this way. In addition, over 650,000 patients were treated through outpatient services, on less than 5 percent of the budget. Outpatient services are extremely costeffective and while they are not unrelated to the number of inpatients, there is sowe scope for expanding them relatively more rapidly than other services. $2 /$ The Ministry of Public Health (MOPH) is attempting to establish a medical referral system that begins at the Basic Health Centers and leads through the provincial and regional hospitals to the large and specialized hospitals of Kabul. Patients would be referred upwards through the hierarchy to the lowest level able to treat them. To bring hospital services closer to

1/ In Afghanistan, one $T B$ treatment is rarely sufficient to cure. Unit treatment costs from MSH, Flnanclal Analysis of Health Programs, Kabul, 1977.

2/ Average outpatient costs assumed equal to those of a Basic Health Center visit. More than half of assumed in-patients not documented (see para. 9.22). 
the people, a network of hospizals has been established ranging from hospitals of over 100 beds in Kabul down to small 10-bed hospitals in provincial centers. The current distribution of hospitals by size (as well as the targets of the Seven-Year Plan) is given in the following table.

Table 44: HOSPITAL, BEDS BY SIZE OF HOSPITAL /a 1976/77 - 1982/83

\section{Size (beds)}

101 and above

51 - 100

$26-50$

$11-25$

10

Al1 Hospitals

$\frac{1976 / 77}{\text { No. Tota } 1 \text { Beds }}$

$6 \quad 1340$

$9 \quad 647$

$8 \quad 269$

11190

$24 \quad 240$

58
2686

$\frac{1982 / 83}{\text { No. } \quad \text { Iota1 Beds }}$

10

2255

412

$\begin{array}{ll}16 & 579 \\ 21 & 400\end{array}$

$13 \quad 130$

la Excluding Ministry of Defense institutions.

Source: Ministry of Public Health.

9.22 In evaluating the system of hospital in-patient care per se, two important issues stand out: the equity and efficiency of the system. Both the distributicn and utilization of hospital in-patient services in Afghanistan are inequitable. Approximately 61 percent of all hospital beds open to the public, are located in $\mathrm{Kabul}$, and the remainder are all located in urban provincial centers. I/ Primarily for this reason, the majority of hospital patients are also urban - in $1975 / 76,48$ percent of al1 in-patients in Kabul hospitals came from Kabul itself, and 78 percent of those of provincial hospitals came from the same town. $2 /$ The distribution of those who utilized hospical in-patient services was also heavily biased, as is shown in Table 45 below.

If See Vo1. II, Table 13.1.

2/ Source: In-patients in Afghanistan Hospitals - 1354 Report, Ministry of Public Health, Kabul, 1976. 
Table 45: HOSPITAL IN-PATIENTS BY AGE AND SEX - 1975/76

(Percent)

\begin{tabular}{|c|c|c|c|c|}
\hline \multirow[b]{2}{*}{ Age } & \multicolumn{2}{|c|}{ Rabul Hospitals } & \multicolumn{2}{|c|}{ Provincial Hospitals } \\
\hline & Male & Fema le & Male & Fema le \\
\hline $0-4$ & 2 & 1 & 2 & 1 \\
\hline $5-14$ & 5 & 3 & 6 & 2 \\
\hline $15-44$ & 42 & 17 & 53 & 15 \\
\hline $45+$ & $2 \underline{4}$ & 6 & $\underline{18}$ & 3 \\
\hline $\begin{array}{c}\text { Sex of Total } \\
\text { Total }\end{array}$ & 73 & 27 & 79 & 21 \\
\hline
\end{tabular}

Source: As for Table 41 .

Males comprise 73 percent of all in-patients in Kabul ( 79 percent in the provinces), while children below age 15 comprise only 11 percent of all inpatients, in both cases. Once again this pattern is the exact reverse of the priorities laid down by MopH. Adult urban males, the least susceptible group to 1llness, receive over 65 percent of MOPH hospital services, while children under 5 who comprise half of total mortality receive only 3 percent. $1 /$ Hospital services are free; however, in practice a hospital stay can become quite expensive. Transport to Kabul, medicines available in the bazaar bue not in the hospital, and blood (if necessary), are major expenses. Private rooms and private consulting are optional extras,

9.23 Hospital services operate inefficiently for a variety of reasons. The principal reason lies in the inability of the many small hospitals to cure patients, most of whose illnesses are well advanced and for whom hospital care has become the last resort. Consequently, many patients die, and many more become wary of entering. In fact, as the following table indicates, once the deciston is made to enter a hospital, many patients appear to want only the best and proceed directly to Kabul, effectively by-passing the referral system.

1/ In financial terms, the distribution is even more skewed as the average cost per adult in-patient is approximately Af 4,000, while the average cost per child in-patient is only Af 1,930. Source: MSH, Financial Analysis of Health Programs, Kabu1, 1977, Table 2. 
Table 46: MOPH HOSPITAL OCCUPANCY RATES BY HOSPITAL SIZE (1975/76)

Size (beds)

101 and above

$51-100$

$26-50$

$11-25$

$1-10$

Al1 Bospitals

Kabul Hospitals

Provincial Hospitals
Bed Occupancy Rate (\%)

104

59

66

54

32

78

103

52

Note: Excludes Ministry of Education, Ministry of Defense, and restricted hospitals.

Source: Ministry of Public Health.

Kabul hospitals have over 100 percent occupancy (patients overflowing into hospital halls, and two-to-a-bed are not uncommon), whereas provincial hospitals have a rate of only 52 percent. This includes 240 beds in 10 -bed hospitals - about 20 percent of provincial hospital beds - that have an occupancy rate of only 32 percent. Il This pattern of much higher occupancy rates at the largest hospitals in the capital, is typical of many developing countries and reflects an accurate assessment by patients and their families that treatment will be better in these hospitals.

9.24 The hospital program absorbs about 65 percent of the MOPH development budget, and about 40 percent of MOPH recurrent expenditures, yet the effectiveness of the program is open to serious doubt. Mortality among patients is high. Part of the problem undoubtedly stems from many patients entering hospitals only when it is too late, buc part also probably relates to the quality of care. Even in Kabul, hospital hygiene is well below international standards, and in the provinces, conditions are still worse. In future, primary emphasis will have to be placed on increasing the efficiency and quality of hospital care. High quality hospital care is expensive, but as MOPH with its small provincial hospitals has discovered, quality hospital care cannot be compromised. MOPH must re-orlent its development plans so as to emphasize quality at the expense of quantity to make as effective use as possible of limited finances and manpower resources.

9.25 It may seem curious on the surface to argue for better quality hospital care when clearly the emphasis of health services must be on broader

1) The 10-bed hospitals are nctoriously inadequate and provide little, apart from bedrest and round-the-clock care, that a properly equipped Basic Health Center cannot. 
coverage. Streamlined, efficient hospital services are not inconsistent however with a broader based referral system which permits treatment of minor complaints through Basic Health Centers. To achieve this, first, the small 10-bed hospitals should be given up. Not only are they inefficient, but worse still, they are ineffective. Emphasis should be put on the development of large regional hospitals where economies of scale allow effective treatment. Fortunately, MOPH is taking a significant step in this direction. As part of the Plan, five new 250-bed hospitals will be constructed in large regional centers. I/ In addition, no new 10-bed hospitals w11 be constructed, and many existing ones will be upgraded to 15 to 25 -bed units (see Table 44 ). However, this measure does not go far enough, for even 25-bed hospitals can efficiently treat only a very limited number of illnesses. A better approach would entail giving them up entirely in those provinces where larger, betterequipped hospitals exist, and transferring the staff and equipment to larger hospitals where they could be more fully and effectively utilized or, better sti11, to Basic Health Centers. The MOPH is currently studying the possibility of converting 20 district hospital buildings into Basic Health Centers with a few rest beds. In provinces where no larger hospitals exist, all but one should be given up, which should be upgraded to the 25 -bed level and reasonably well staffed and equipped. Such a strategy would result in somewhat fewer but: better equipped and staffed hospitals capable of treating more varied illnesses than lefore. This would help build confidence in provincial hospitals, and so increase their utilization, the key to efficient, cost effective in-patient hospiral services.

9.26 A second area in which hospitals could become more efficient is in the in-patient/out-patient mix. A large proportion of in-patient costs are hotel costs - meals, laundry, and other services - that have little relation to treatment. Many patients enter hospitals with diseases (many respiratory and digestive diseases, for instance) that could be treated just as effectively but at lower cost on an out-patient basis. $2 /$ Attempts should be made to identify such patients and treat them as outpatients instead. Similarly, actempts should be made to reduce the length of in-patient stay. Currently the average stay in general hospitals is 12.3 days; in Kabul, 16,6 days. This is far longer than the average stay in developed countries. Although many Afghan patients are aor seriously 111 than their developed country counterparts, even relatively routine cases like appendicitis are followed by far longer post-operative in-patient care. Part of the answer is that the Government of Afghanistan should consider the imposition of an effective fee-forservice system. As the system expands and hospital visits increase, costs are

1/ This will also help improve the balance of hospital beds between Kabul and the rest of the country. By the end of the Plan, only 41 percent of hospital beds will be in Kabul.

2/ Out-patient services are also more equitably utilized: 16 percent are infants, 22 percent are children $1-4,22$ percent children 5-14, while 17 percent are adult females and only 23 percent adult males. Apparently adult males enter hospitals for many illnesses for which other groups are treated on an out-patient basis. 
going to soar. Measures to increase efficiency will help, but not solve the problem, whereas charging fees would encourage patients to seek out-patient treatment, to keep hospital stays short, and ease pressure on the MOPA budget. All of which would allow the provision of better health care. A start has been made by levying charges for private rooms, laboratory tests and blood transfusions. Further moves in this direction are needed. In the absence of health insurance schemes, a fee assessed on ability to pay would be a workable and equitable solution. $1 /$

\section{(ii) Basic Health Services}

9.27 The Basic Health Services program is the principal focus of the MOPH rural health effort. The program began with the establisnment of 4 Basic Health Centers in Parwan province in 1968/9. By mid-1977 this number had grown to 114 in all 26 provinces, and by the end of the Plan, 193 are expected to be in place. In 1976/77 Basic Health Services received about 17 percent of MOPH ordinary budget allocations, and are to continue receiving this percentage throughout the Plan. About 23 percent of MOPH development expenditures during the Plan are allocated for the construction and equipping of BHC. The BHC is a multi-purpose health institution, providing both preventive and curative services. Each BHC has a professional staff of 7 comprising 1 doctor, 1 male nurse, 1 auxiliary nurse/midwife, 1 sanitarian, 1 lab-technician, and 2 vac. cinators. Patients whose iliness can be cured with available medicines are treated on-location; more serious cases are referred to the nearest hospital. BHCs provide no in-patient services. Preventive services include sanitarians who are supposed to spend most of their time in the surrounding area impressing. upon people the need for proper hygiene and clean water, varcinators as part of the mass immunization program, and the provision of World Food Program (WFP) supplies to expectant and nursing mothers and young children.

9.28 The Basic Health Centers have not yet had the impact on rural health they were intended to. A large part of this stems from the dispersed nature of the population and the inadequacy of transportation facilities. Although some patients come from over $15 \mathrm{~km}$ away, a survey of five BHCs in Parwan province indicated that half the patients came from between 2 and 6 kilometers. $2 /$ For practical purposes, the BHCs had catchment areas of about 6 kilometers. As a consequence, BHC urilization has been limited - even assuming only one visit per patient, to approximately 495,000 visits per year, i.e., less than 6 percent of the cotal settled rural population visited a BBC in 1976/77. $3 /$ The average number of visits to each of the 114 BHCs daily is less than 12 . This represents serious underutilization of the services. And if such utilization

1) That such a system can function in Afghanistan is known; a large, we 11run semi-private eye clinic in Kabul charges from zero to Af 500 per visit, depending on how they assess ability to pay. The fee deters no one, and all praise the quality of treatment.

2) MSH, Parwan Basic Health Center Pilot Project - Evaluation Report, Kabul 1976.

3/ Estimate calculated from MOPH Report of Health Activities, first and second quatters, 1977 and IBRD population estimates. 
patterns were to persist, the completed network of 193 BHCs would receive only about 838,000 visits annually by $1982 / 83$, which (assuming only one visit per patfent) would still comprise less than 7 percent of the rural population.

9.29 If BHCs are to have significant impact on the rural health scene, then utilization will have to increase greatly. The key to increasing their utilization is enabling them to provide the services they were intended but which, for lack of staff and materials, they are unable to provide at present. The lack of staff is a serious problem. While almost all BHCs have doctors, the supply of other staff is inadequate. Female staff are in extremely short supply - in mid-1977 only $32 \mathrm{BHCs}$ had auxilfary nurse/midwives. Yet female staff are essential if large numbers of women and children are to use the Center. Measures are being taken however, to alleviate the shortage (see para. 9.46). On the other hand, 54 BHCs have lab technicians. Questions have been raised as to the need for this activity at the BHC level. In terms of overall supply, lab technicians are expected to be in severe shortage. Under these circumstances it may be more appropriate at this stage to station lab technicians at the provincial hospital level where their services could be effectively utilized.

9.30 But perhaps the ereatest problem is the supply and management of drugs. Currently a 11 BHC medicines are divijed up into 114 equal shares, irrespective of the relative utilization of particular BHCs. In consequence the more heavily utilized BHCs find their annual share of drugs insufficient for more than six month' operations; in some cases more than 70 percent of all patients must be referred to pharmacies. Of course, if pharmacies are convenient this presents litcle problem, but in most cases they are not. Under these circumstances, many of those who are 111 do not bother visiting BHCs at all. Proposals have been made to rationalize the drug distribution system; they must be implemented. The first step involves reorganizing the warehouse, logistics and information system to ensure adequate supplies of drugs when and where they are needed. A second equally 1 mportant aspect involves rationalizing the drug stocks themselves. Surveys conducted at BHCs have indicated that the 10 most common diagnoses accounted for 57 percent of all diagnoses and the 25 most common accounted for 85 percent. The standard drug issue cuntains 58 items, some of which are outdated and others little used. A revised list of 40 drugs has been found capable of treating 90-95 percent of all patients who visit BHCs. A full complement of staff and adequate drugs tripled BHC visits to over 26,000 per year in the Parwan pilot project. If the utilization can be increased in other BHCs to the same extent, the envisioned 193 BHC network could reach 3.9 million or about 29 percent of the rural population by $1982 / 83$. With the program reaching this number of people, if MOPH wishes to keep drug costs down and still be able to provide adequate service to all patients, there will have to be at least a small charge for drugs, with funds earmarked for financing MOPH programs and not transferred to the general budget.

9.31 In addition to the BHCs, the MOPH proposes to increase rural coverage through the establishment of health sub-centers. Eventually between one and three sub-centers would be attached to each BHC. Each sub-center would be staffed full-time by one nurse and one vaccinator, and would be visited once 
a week on a predetermined day by the doctor of the BHC to which it is attached. This is a logical approach, and may in the long run be part of the solution. towever, at present, this appears to be overextending the BHC system before it yez $;$ a chance to establish itself firmiy. Although 73 such sub-centers existed on paper by mid-1977, very few were operational. Management problems including zransportation and accommodations, not to mention shortages of drugs and wanpower, currently plague the program. Given the numerous constraints under which the BHC program and MOPH in general operate, it makes better sense to delay the sub-centers and concentrate on consolidating the existing BHC program. This would be done by proper staffing, adequate supplies of drugs, and outreach activities such as increased participation in community affairs, vaccination programs in local schools, and house visits by sanitarians and female statef to impress on the population the necessity of improved nutrition, hygiene nad sanitation. But in these respects the BHCs must practice what they preach. Jery few have efther a source of unpolluted water or proper sanitation, and WFP tou supplements are $\mathrm{few}$ and far between.

Q.32 Surveys show that the public generally holds the BHCs in high esteem; when a BHC is nearby, one third of those questioned believed it was the best source of treatment for iliness not curable at home. $1 /$ There were complaints nowever -- lack of medicines, petty corruption, and distance, One important and positive finding was that in only 7 percent of the cases were females not particted by husoands and fathers to visit the BHC. The BHC concept is sound zac what is needed is to increase their utilization. Not only would this make hore efficient use of scarce trained medical manpower, but could also dramatcaliy increase che effective coverage of the rural population.

\section{(iii) Village Health Worker}

Y.33 The NOPH realizes that the current network of hospitals and BHCs is thadecuate for providing the majority of the nation's 10.5 million rural incaditans scattered in some 20,000 villages with basic medical care. Therefore it has been decided to introduce a Village Health Worker (VHW) program mode..lec on the "barefoot doctor" schemes of other countries. Under the screve, volunteers chosen by the villagers and screened for suitabitty by YOPH woutd undergo intensive training for eight weeks at a specialiy equipped 2tic. They would be instructed in matters of fundamental hygiene and nutriion, and be taught to diagnose and treat simple illnesses. They would be attacied to the nearest BHC, from which they would draw supplies and to which they would refer more serious cases.

Y.34 The success of the VHW approach is largely conzingent upon the degree to which the VHW scheme can be integrated into the parochialism of everyday $\therefore$ ghan village life and the village social structure. A sensible approach is seing adopted to insure this by seeking to give the VHW status similar to that of the malik, mirab and mullah (see para. 1.09). To begin with, each village rust make certain commitments: services and drugs must be paid for by the village (in a manner to be determined by the villagers themselves), and the

1 Source: MSH, The Village Health Worker: The Need and Potential as Determined by Survev in Three Provinces in Afghanistan, Kabul, 1977. 
village must demonstrate interest in the scheme. The VHWs should be literate, preferably of reasonable economic status, and be from the same village. Villagers are traditionally wary of outsiders; by being from the same village the need to fight for acceptance 1 s minimized and the ability to influence strengthened. But perhaps the most important condition of a 11 to ensuring the success of the program is providing the VHWs with a suffictent supply of drugs. Afghans have enormous confidence in drugs; fallure to supply the VHWs adequately would seriously undermine their credibility and jeopardize the entire program.

9.35 The pilot stage of the program began in mid-1977 with the graduation of. 40 VHWs in the eastern region. Contingent upon the success of the pilot program, up to 1500 VHWs will be trained by the end of the Plan. Details of the proposed program are as follows:

Table 47: VHW PROGRAM - PROJECTED NUMBER OF BHC, VILLAGES AND VHW $1977 / 78-1982 / 83$

\begin{tabular}{|c|c|c|c|c|c|}
\hline 1977178 & $1978 / 79$ & $1979 / 80$ & $1980 / 81$ & $1981 / 82$ & $1982 / 83$ \\
\hline 3 & 10 & 20 & 32 & 46 & 60 \\
\hline 30 & 120 & 260 & 443 & 690 & 1000 \\
\hline 45 & 180 & 390 & 665 & 1035 & 1500 \\
\hline
\end{tabular}

la Program does not include all BHCs - 196 by end of Plan.

Source: MSH, A Proposed Village Health Worker Program for the People of Afghanistan, Kabul, 1977.

(1v) Water Supply

9.36 Although contaminated water has been 1dentified as a major cause of illness and disease in Afghanistan, a recent IBRD-WHO sector survey indicated that at most 5 percent of the population has potential access to public water supply systems $1 /$. The water supply program is weak by international standards - total development expenditure on water supply in the Plan is estimated at Af 3.1 billion, only about 1.3 percent of total out lays. 43 percent of these outlays are for Kabul, 42 percent for rural water supply projects and 15 percent for other urban systems. Approximately 57 percent is to be financed through foreign assistance.

9.37 The responsibility for providing drinking water is split between the Central Authority for Water and Sewerage (CAWS), a quasi-independent authority in the Ministry of Fublic Works which is responsible for the provision of water and sewerage systems to the 87 designated urban areas, and the Environmental Health Department (EHD) of the Ministry for Public Health which is responsible for the provision of clean water to rural areas. In practice, however, the 
distinction has been less clear-cut - EHD has installed systems in nine minor urban areas.

9.38 EHD has a target of providing 25 percent of the rural population with potable water by the end of the Plan, a goal the sector survey believes $1 t$ is unlikely to achieve. It current $1 \mathrm{y}$ serves at most 300,000 people, less than 3 percent of the rural population. (The actual number is probably far less, as up to half the installed systems are currently not operational.) On the basis of current implementing ability, the targets for the Plan appear unattainable; the sector survey estimates that the program will probably only reach about 1.6 million people, less than half the original target. UNICEF has pledged its support to the program, and no constraint in the supply of materials and equipment to meet the target is evident. The primary constraint appears to be a lack of counterpart local resources. Rural water supply is not the priority item to Government of Afghanistan that it should be, considering its importance to public health. Including foreign assistance, it was only budgeted at 3.8 percent of health expenditures in $1977 / 78$; and the Ministry of Public Health itself receives one of the smallest allocations - only 2.5 percent of the budget. A major increase in effort and allocations is needed even to attain its declared goal of 25 percent rural coverage during the Plan, a goal that should indeed be far higher.

9.39 Urban water supply programs have to date concentrated on the five principal urban centers: Kabul, Kandahar, Herat, Jalalabad, and Mazar-iSharif. Although these systems are all functioning, coverage currently varies from 14 percent for Kandahar and 22 percent for Kabul, to over 90 percent for Jalalabad. All these systems are currently being expanded, and will consume a major portion of CAWS' allocation over the Plan. CAWS will also continue with the implementation of water supply schemes in four other towns. The Plan also calls for the provision of supplies to a further 10 towns, and the sector survey believes these are currently beyond the implementing ability of CAWS. No provision at all is being made for the remaining 72 municipalities. Part of the reason for CAWS' slow implementation rate is undoubtedly resources, but it may also be in part a consequence of the strategy of concentrating on suppij through house connections (except for public standposts at mosques). To supply water to all inhabitants under such a strategy requires of course connections at all households. Not only is this more expensive than reducing the number of house connections and providing some public standposts as weII, it is also more time-consuming. Considering the number of urban centers which would otherwise be without piped water supply during the Plan, CAWS should focus on delivering water to more towns but on a less intensive scale than currently planned. This would enable the limited manpower and physical resources at CAWS' disposal to be used in a more effective manner in terms of the number of urban inhabitants reached. Then, at a later stage, these systems could be expanded into providing a larger number of direct household connections.

(v) Mother and Child Health Care (MCH) Services and Nutrition Prugrams

9.40 The current $\mathrm{MCH}$ program has two components. The first is a series of 37 urban clinics - 1 per province (except Zabu1), and 13 in Kabul ( 9 ful1time and 4 satellite clinics). These clinics provide expectant mothers with 
TRbLe 50: POPULATION IEALIH COVERAGE 1975/76 - 1985/86

\begin{tabular}{|c|c|c|c|c|c|c|c|c|c|c|c|c|}
\hline & $\begin{array}{r}1975 / \\
76 \\
\end{array}$ & $\begin{array}{r}1976 / \\
77 \\
\end{array}$ & $\begin{array}{r}1977 / \\
78 \\
\end{array}$ & $\begin{array}{c}1978 / \\
79 \\
\end{array}$ & $\begin{array}{r}1979 / \\
80 \\
\end{array}$ & $\begin{array}{c}1980 / \\
81 \\
\end{array}$ & $\begin{array}{c}1981 / \\
82 \\
\end{array}$ & $\begin{array}{r}19821 \\
83 \\
\end{array}$ & $\begin{array}{r}1983 / \\
84 \\
\end{array}$ & $\begin{array}{r}1984 / \\
85 \\
\end{array}$ & $\begin{array}{r}1985 / \\
86 \\
\end{array}$ & \\
\hline 1. BHC (No.) & 101 & 107 & 114 & 127 & 141 & 157 & 174 & 193 & 200 & 208 & 217 & \\
\hline $\begin{array}{l}\text { 2. Population with } \\
\text { Access (per BHC) }\end{array}$ & 17,400 & 17,700 & 18,100 & 18,500 & 18,800 & 19,200 & 19,600 & 20,000 & 20,400 & 20,800 & 21,200 & \\
\hline $\begin{array}{l}\text { 3. Total Coverage - BHC } \\
((000)\end{array}$ & 1,757 & 1,894 & 2,063 & 2,350 & 2,651 & 3,034 & 3,410 & 3,860 & 4,080 & 4,326 & 4,600 & \\
\hline 4. VHW (No.) & - & - & 45 & 180 & 390 & 565 & 1,035 & 1,500 & 1,965 & 2,430 & 2,895 & \\
\hline 5. Villages (No.) & - & - & 30 & 120 & 260 & 443 & 690 & 1,000 & 1,310 & 1,620 & 1,930 & \\
\hline 6. Village Population & - & - & 536 & 546 & 557 & 568 & 580 & 591 & 603 & 6.15 & 627 & \\
\hline $\begin{array}{l}\text { 7. Total Coverage VHW } \\
(1000)\end{array}$ & - & - & 16 & 66 & 145 & 252 & 400 & 591 & 790 & 996 & 1,210 & \\
\hline $\begin{array}{l}\text { 8. Major Urban Coverage } \\
\text { (millions) }\end{array}$ & 1.54 & 1.60 & 1.65 & 1.71 & 1.77 & 1.83 & 1.90 & 1.96 & 2.03 & 2.10 & 2.18 & \\
\hline 9. Total Coverage & 3.30 & 3.49 & 3.73 & 4.13 & 4.57 & 5.12 & 5.71 & 6.41 & 6.90 & 7.42 & 7.99 & 1 \\
\hline $\begin{array}{l}\text { 10. Total Population } \\
\text { (millions) }\end{array}$ & 13.70 & 14.00 & 14.31 & 14.62 & 14.95 & 15.27 & 15.61 & 15.95 & 16.31 & 16.66 & 17.03 & $\frac{1}{10}$ \\
\hline 11. Percent Coverage & 24.1 & 25.0 & 26.1 & 28,2 & 30.6 & 33.5 & 36.6 & 40.2 & 42.3 & 44.5 & 46.9 & \\
\hline
\end{tabular}

Notes: (1) BHC estimates based on revised Plan projections. 1985/86 estimate based on original Plan projection.

(2) Based on average catchment population in Parwan BHC pilot project. Catchment population assumed to increase at $2 \%$.

(4) Based on pilot project targets. Annual increment 1983/84 - 1985/86 assumed equal to increment of last year of Plan.

(5) See (4).

(6) Based on 1976/77 estimate of 525 (10.5 million, 20,000 villages). Assumed to grow in size at rural population growth rate of $2.0 \%$ per annum,

(8) Population of major urban centers assumed to have access. Largest 14 centers assume $100 \%$ access, next 25 centers $50 \%$ access, smallest 48 , $0 \%$ access. Based on adjusted ADS estimates, Urban populations assumed to grow at $3.5 \%$.

(10) IBRD estimates - see Vo1. II, Part II, Section I. 
If the VHW pilot program is introduced and implemented azco: $\angle \Delta g$ zo the present proposals, total coverage would rise to about 40 percenz of ite jopularton, and within three more years $(1985 / 86)$ to almost 47 percent c E the pozilation. $1 /$ As the number of small villages is very large and they compise $\$ 0$ sch of the total population the VHW program is clearly the only viajle zeans of providing widespread health services at low cost. For this reasor, it aus expand at a much faster rate than currently envisioned if all Afghass are to jave access to health services by, say, the end of the next Seven-Iear ?lac in $: 989 / 90$. As the program currently stands, the cost of 1500 VHWs by the eat of the Plan is budgeted at Af 33.5 million, only about 2.5 percent of estirazec zczal cost of health programs. $2 /$ There is clearly room for more rapid exassios.

9.65 Improving the quality of health care in a deliver: sps:az undergoing constant expansion with free provision of health services, tr:s: inertibly result in soaring costs. Indications are that the annual judge: $z=$ cperating expenses is not being increased rapidly enough to cover zeecs, ts the detriment of the quality of public health. Unless the Goverzient is riling to comit itself to the substantial costs of totally free bealti serices, by way of the required budget allocations, free health services wil: necassarily mean limited health services. The population attaches tremeacious imczaace to health care, and, as surveys have shown, spends large acouncs or $\leq:$. To deny people health sevices for which they are willing to pay, in tie =ace of providing free services, is inconsistent. A fee-for-service spstec siould be introduced. There is every indication that most Afghans wouli preiez a system under which they paid a modest charge but received good sreazer: tican inadequate service provided free. For instance, drugs could be cisargez as cost to help purchase more drugs and a daily inpatient charge could be assessed based on the ability of the patient to pay. The latter would excourage core efficient use of the hospital system. The outpatient/inpatient mis would $\Longrightarrow=0 v e$, stays would become shorter and more patients culd be accomodased bithi= the system. This would reduce expansion needs, lower overhead costs per pasters, and allow the provision of better service. It is crucial however, tha: zeraune collected under these programs (particularly drugs) be returned to MOPE to al:ow the purchase of future supplies, and not be swallowed up in general goverarent revenues.

9.66 Hospital care is an important element of any cocer puizic health care delivery system, but in Afghanistan it is being overempasizec celative to preventive health programs. Hospitals are primarily sutied to tis curative

1/ These estimates are for people with potential access, no: actual utilization. In $1976 / 77$, actual utilization of each BEC was o=i! $t, 300$ visits on average (compared with population with access of 17,700 ). Also, to the extent the largest $B H C$ catchment areas are already explcted, the above BHC projections may be overestimates.

2/ Assumes al1 costs borne by MOPH, and includes Af 30.0 fillioz for drugs. The recent introduction of swall charges for drugs issued br the VHW should reduce MOPH costs for the VHW program to minizal leveis. Permitting VHWs to charge for drugs, but not BHCs and hospitals does however introduce an anomaly whereby those paying are probably zhe poorest groups. 
treatment of episodic illness, not the ongoing problems of malnutrition, contaminated water and poor environmental hygiene that face most Afghans. Hospital services are subject to significant economies of scale and as a result tend to be concentrated in large urban centers, Ihis makes the distribution of health sevices under such a hospital-oriented system inequitable -- in Afghanistan approximately the same number of urban and rural inhabitants have access to health services despite there being some 6 times as many rural inhabitants. Urban services are undoubtedly of higher quality too, with their more-assured supplies of drugs and manpower. Clearly there is a need to re-structure the system of incentives to trained personnel especially doctors so that they are able to take up positions outside the capital without losing additional income in the process.

9.67 If public health in Afghanistan is to improve in the long-run, the principal causes of poor health - contaminated water, malnutrition, etc. will have to be eliminated. The focus of health care must shift from curative urban-oriented hospital care to the promotion of preventive measures undertaken from within the village on a continuous basis. Unfortunately, recent budget cuts have reflected the opposite - hospital services have been cut much less than other services. This must change because curative care of preventable diseases is an enormous waste of resources (the average inpatient costs about Af 4,000 to treat, whereas the cost of providing clean water in rural areas is on $1 y$ about Af 30 per recipient) and is of limited effectiveness. Reorienting the health program towards preventive services entaj,ls expanding rural water supply, immunization, and health education programs. (This would not mean an absolute reduction in curative expenditures and indeed the effective coverage of these programs would continue to exfand through rationalization and increased efficiency.) Implementation of rural health programs is critically dependent upon successful expansion of the VHW program. In conjunction with the BHC staff the VHWs must assume Jeadership roles in health education they must visit homes and schools to discuss the importance of proper nutrition particularly for the young, and to explain the vicious circle of poor environmental sanitation, contaminated water, and poor health.

9.68 The health problems of Afghanistan are serious and basic. Tuey call for a public health system that focuses on widespread adoption of simple lowcost preventive health measures and, as the illnesses arising from such conditions subside, increasingly devotes itself to problems that require genuine curative measures. The current system has taken the reverse approach with the consequence that health services are inequitably distributed, largely inappropriate and inefficient. Fortunately there is a new awareness of this and an impressive beginning has been made through the introduction of programs like the BHCs, VHWs, and rural water supply. However, these programs do not as yet get the priority and support they need. Until they do, Afghanistan will continue to have one of the poorest health records in the world. 
13.80 The growth path delineated in Table 77 , represents what could be achieved in the context of a major effort to carry out the measures which we have proposed in this Report. It implies also a considerable acceleration in Afghanistan's savings and investment efforts. The resource implications of the projection are shown in Table 78 below. These figures are derived in many cases through arbitrary assumptions. The usual strictures about treating the figures with caution apply even more strongly in this case.

\section{Table 78: EXPENDITURE FLOWS $1975 / 76$ TO $1982 / 83$} (USS millions in $1975 / 76$ prices)

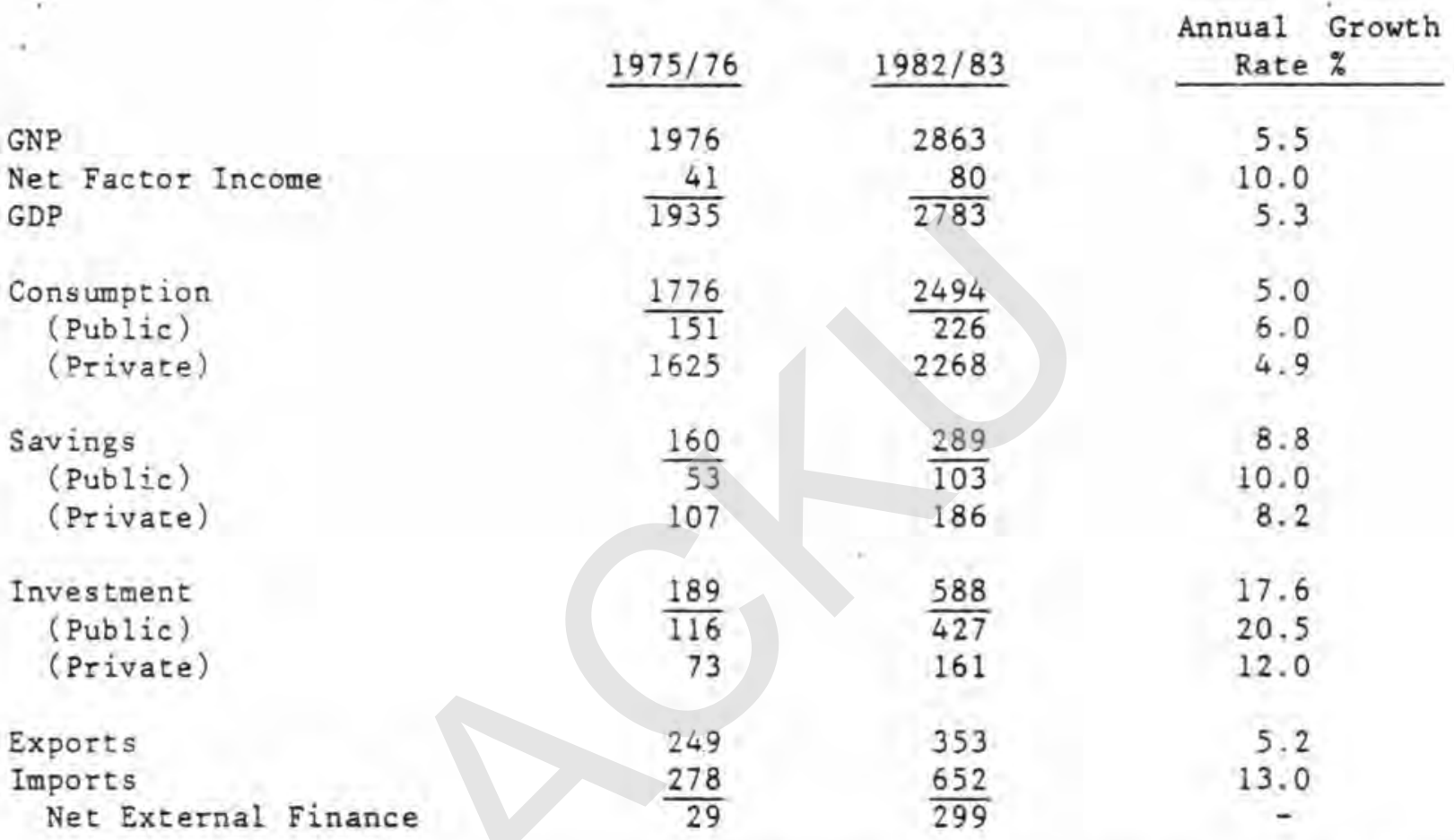

The implied increase in investment is substantial. It would rise from 10 percent of GNP in $1975 / 76$ to over 20 percent in $1982 / 83$. The savings effort required to finance such an increase does not seem unreasonable however. Savings would rise from about 8 percent of GNP in $1975 / 76$ to about 10 percent in 1982/ 83. This implies a marginal savings rate of about 15 percent. This should indeed be achievable in the context of a strategy to promote private savings and investment on the one hand, and reduce subsidies financed by the Government budget for consumption on the other. The increase in per capita private consumption of about 20 percent combined with income redistribution as a consequence of land reform should permit a substantial reduction in absolute poverty. The target for external finance implies a very large increase, but this is consistent with the improvements in absorptive capacity which would take place if there is the requisite effort to carry out the recomendations. The constant price data makes Afghanistan's projected external performance look rather worse than it is, since a substantial terms of trade improvement is expected. In addition exports rise very rapidly after $1982 / 83$ as new capacity comes onstream. 
XIV. CONCLUSIONS

14.01 In 1971 a World Bank mission wrote of the pervasive "disillusionment about the past and pessimism regarding the future" in Afghanistan. They concluded that "such pessimism is justified as even in areas where development activities were undertaken, with heavy inputs of capital investment and foreign advice, returns have been dismally low". Afghanistan was at its nadir. Two years of drought had led to a doubling of wheat prices and large numbers of livestock were being slaughtered. The balance of payments was in dire ștraits and the Government requested a moratorium on 1ts debt payments. The mission identified four elements which underlay the critical situation; first, the ineffectual administration and the scarcity of competent officials; second, the inabllity to "devise or follow an effectlve development strategy"; third, the poor financial management and inadequate tax effort; and fourth, the failure to manage the external sector so as to provide sufficient incentives for exports. The Report states that "This list could be lengthened. Sufficient has been said, however, to show that there are very substantial obstacles to progress and that those responsible for the conduct of development are certain to be faced with great difficulties in their efforts to proceed effectively and expeditiousiy. It is clearly impossible to remove all the obstinles in a short period of time". $1 /$

14.02 The pessimism of 1971 was not solely a reflection of the weaknesses of the management of the development effort however. There was also a perception of Afghanistan as a country with limited development potential in the longer term. In this respect at least, there is no longer cause for pessimism. In 1977 the economic outlook gives promise that substantial progress can be made in the next ten years towards the goals of higher income levels and meeting the basic needs of the population. Let us spell out the changes which have led to this conclusion. In 1971 it was difficult to tdentify the elements of a growth strategy for Afghanistan. The major emphasis was on the achievement of food self-sufficiency. The tiny domestic market offered little prospect for industrialization; indeed most of the obvious potentials had been tapped through the large state enterprises which were poorly run and operating at low levels of capacity utilization. While exports did offer some potential, Afghanistan seemed unlikely to be able to compete effectively given its distance from world markets.

14.03 In the interim major changes have taken place. The harvests of 1972-1976 have made it clear that Afghanistan is indeed already self-sufficient in food in normal years. Increased yields are needed not to insure food selfsufficiency in drought years as well, but to enable valuable irrigated land to be diverted to higher value cash crops with export and industrial potential. Food security can be achleved through programs of imports, domestic procurement and storage, so that the economic impact of the occasional drought. year is minimized. The steady rise in prices of primary commodities, has benefitted Afghanistan's exports. The oil price rise has benefitted nearby

If Op. cit. pp. 1 and 2 . 
markets which Afghanistan is almost uniquely well-placed to serve with agricultural products, A strategy which is led by agricultural exports, increasingly in processed form, has already begun to take shape. Rising prices for minerals have made the exploitation of Afghanistan's reserves commercially viable in a number of cases, so that the export drive can proceed along a broader front. The export opportunities are supplemented by good prospects for import substitution of some items. The substantial inflow of remittances from Afghan workers abroad should insure buoyant domestic demand in addition to attractive export markets.

14.04 Whether these opportunicies will be taken, depends to a large extent on the Government. Again there is room for a positive assessment. The key agricultural institutions, the AgBank and the Fertilizer and Seeds Corporations, have registered real progress and can confidently be expected to make a major contribution to agricultural growth in the years ahead. The trend of Government policy on foreign exchange management has been in the right direction. There has been no attempt to reduce the openness of the economy, and the adequacy of export incentives has been kept under careful review. The progress in increasing tax revenues has been impressive, though there is a worrisome trend towards large hidden budgetary subsidies. Capacity utilization in the state enterprises has risen substantially. The rural development program gives promise of a genuine impact on rural living standards. The Government is committed to land reform and greater equality of income distribution. Indeed for almost the first time in Afghanistan's history, there is no question of the Government's commitment to the objectives of economic development and higher living standards for all.

14.05 And yet, the optimism must remain measured. The obstacles to development remain daunting. The civil service is still not development oriented. Most administrators are unmotivated, poorly trained and hampered by an archaic civil service system. There are shortages of almost every category of trained manpower, and even those who have been trained, have been poorly trained. There are any number of pending decisions and proposed reorganizations, and little sign of movement on them. The public sector is strained to the limit by its present responsibilities and what 1 will need to do in those areas of the economy and the sociecy in which only the public sector can act. Yet Afghanistan's leadership has not yet taken steps to harness the potential in the private sector, both domestic and foreign, to supplement the reach of the public sector in promoting the development strategy. The dualism of Afghanistan persists; the modern sector concentrated in Kabul continues to draw the lion's share of infrastructure and attention; the regions with their predominantly rural economies, languish by comparison. The Plan which has been prepared seems to draw its inspiration too much from the dreams of the future, and too little from the harsh realities of the present.

14.06 The Government of Afghanistan has a heavy responsibility. The continuation of the present living standards cannot be countenanced; that only half of those who are born live beyond the age of 5, and even those only have a Iife expectancy of 50; that 10-12 percent of the population can read or write; that one-third of the population live in absolute poverty; that in years of drought, widespread hunger visits the land. A commitment to change 
pe 